

AUTARQUIA ASSOCIADA À UNIVERSIDADE DE SÃO PAULO

Group Method of Data Handling (GMDH) e Redes Neurais na Monitoração e Deteç̧ão de Falhas em sensores de centrais nucleares

Elaine Inacio Bueno

Tese apresentada como parte

dos requisitos para obtenção do Grau de Doutor em Ciências na Área de Tecnologia Nuclear - Reatores

Orientador:

Prof. Dr. Antonio Teixeira e Silva 
Dedico este trabalho aos meus pais, Gilberto e Marinezia e aos meus irmãos, Wellington e Lucineide 


\section{AGRADECIMENTOS}

Ao Dr. Antonio Teixeira e Silva pela orientação e pela confiança depositada para a realização deste trabalho.

À Dra. Iraci Martinez Pereira que tem me acompanhado desde a iniciação científica até a realização do presente trabalho, exercendo a função de co-orientadora. Gostaria de agradecê-la pela amizade, dedicação, paciência e pelos valores que me foram ensinados durante todo este tempo em que trabalhamos juntas.

A todos os meus amigos e colegas do IPEN e IFSP, que colaboraram direta ou indiretamente para a realização deste trabalho.

Aos meus amigos Ridnal Nascimento, Alda Roberta Torres e Vanessa Z. Guirado pelas palavras de incentivo e pelos momentos de distração.

Aos demais amigos e colegas que sempre me apoiaram nos momentos de trabalho intenso oferecendo palavras de incentivo e apoio emocional, com o propósito de impedir que o nível de estresse e cansaço mental prejudicasse a minha pesquisa.

Aos meus pais, Marinezia e Gilberto, e aos meus irmãos, Wellington e Lucineide, pelo apoio recebido durante todo o meu trabalho e por terem me apoiado sempre em todas as minhas decisões.

Aos funcionários da CPG pelo apoio recebido durante a minha vida acadêmica. 
Dificuldades e obstáculos são fontes valiosas de saúde e força para qualquer sociedade. 


\title{
GROUP METHOD OF DATA HANDLING (GMDH) E REDES NEURAIS NA MONITORAÇÃO E DETECÇ̃̃O DE FALHAS EM SENSORES DE CENTRAIS NUCLEARES
}

\author{
Elaine Inacio Bueno
}

\section{RESUMO}

A demanda crescente na complexidade, eficiência e confiabilidade nos sistemas industriais modernos têm estimulado os estudos da teoria de controle aplicada no desenvolvimento de sistemas de Monitoração e Detecção de Falhas. Neste trabalho foi desenvolvida uma metodologia inédita de Monitoração e Detecção de Falhas através do algoritmo GMDH e Redes Neurais Artificiais (RNA) que foi aplicada ao reator de pesquisas do IPEN, IEA-R1. O desenvolvimento deste trabalho foi dividido em duas etapas: sendo a primeira etapa dedicada ao pré-processamento das informações, realizada através do algoritmo GMDH; e a segunda o processamento das informações através de RNA. O algoritmo GMDH foi utilizado de duas maneiras diferentes: primeiramente, o algoritmo GMDH foi utilizado para gerar uma melhor estimativa da base de dados, tendo como resultado uma matriz denominada matriz_z, que foi utilizada no treinamento das RNA. Logo após, o GMDH foi utilizado no estudo das variáveis mais relevantes, sendo estas variáveis utilizadas no processamento das informações. Para realizar as simulações computacionais, foram propostos cinco modelos: Modelo 1 (Modelo Teórico) e Modelos 2, 3, 4 e 5 (Dados de operação do reator).

Após a realização de um estudo exaustivo dedicado a Monitoração, iniciou-se a etapa de Detecção de Falhas em sensores, onde foram simuladas falhas na base de dados dos sensores. Para tanto as leituras dos sensores tiveram um acréscimo dos seguintes valores: $5 \%, 10 \%, 15 \%$ e $20 \%$.

Os resultados obtidos utilizando o algoritmo GMDH na escolha das melhores variáveis de entrada para as RNA foram melhores do que aqueles obtidos utilizando apenas RNA, o que viabiliza o uso da nova metodologia de Monitoração e Detecção de Falhas em sensores apresentada. 


\title{
GROUP METHOD OF DATA HANDLING AND NEURAL NETWORKS APPLIED IN MONITORING AND FAULT DETECTION IN SENSORS IN NUCLEAR POWER PLANTS
}

\author{
Elaine Inacio Bueno
}

\begin{abstract}
The increasing demand in the complexity, efficiency and reliability in modern industrial systems stimulated studies on control theory applied to the development of Monitoring and Fault Detection system. In this work a new Monitoring and Fault Detection methodology was developed using GMDH (Group Method of Data Handling) algorithm and Artificial Neural Networks (ANNs) which was applied to the IEA-R1 research reactor at IPEN. The Monitoring and Fault Detection system was developed in two parts: the first was dedicated to preprocess information, using GMDH algorithm; and the second part to the process information using ANNs. The GMDH algorithm was used in two different ways: firstly, the GMDH algorithm was used to generate a better database estimated, called matrix_z, which was used to train the ANNs. After that, the GMDH was used to study the best set of variables to be used to train the ANNs, resulting in a best monitoring variable estimative. The methodology was developed and tested using five different models: one Theoretical Model and four Models using different sets of reactor variables.

After an exhausting study dedicated to the sensors Monitoring, the Fault Detection in sensors was developed by simulating faults in the sensors database using values of $5 \%, 10 \%, 15 \%$ and $20 \%$ in these sensors database.

The results obtained using GMDH algorithm in the choice of the best input variables to the ANNs were better than that using only ANNs, thus making possible the use of these methods in the implementation of a new Monitoring and Fault Detection methodology applied in sensors.
\end{abstract}




\section{SUMÁRIO}



1.1. Motivação para o trabalho ................................................................................ 1











3.1.1. Descrição da instalação ............................................................................ 13

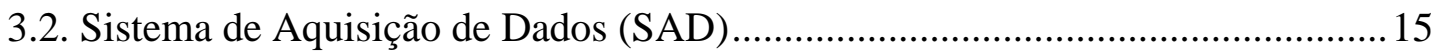

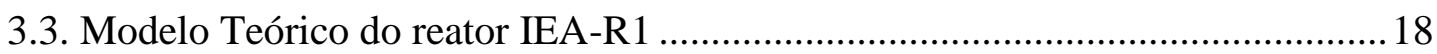



4.1. Group Method of Data Handling (GMDH) .................................................. 21



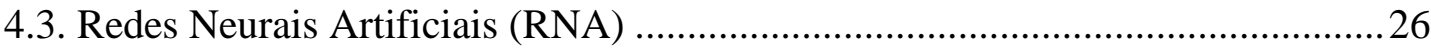

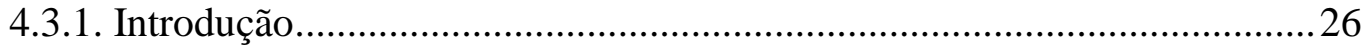

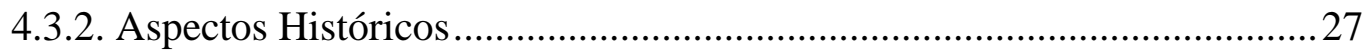

4.3.3. Modelo matemático de neurônio ...............................................................2 29

4.3.4. Arquiteturas de Redes Neurais Artificiais (RNA) ................................... 32

4.3.4.1. Redes de camadas múltiplas (MLP) ........................................ 34

4.3.5. Principais Algoritmos de Treinamento ...................................................... 35



4.3.7. Aprendizagem por competição.................................................................. 37

4.3.8. Aprendizagem por Correção de Erro ........................................................ 37

4.3.9. Regra Delta ou Método do Gradiente Descendente .................................. 38

4.3.10. Algoritmo de Retropropagação ........................................................... 39

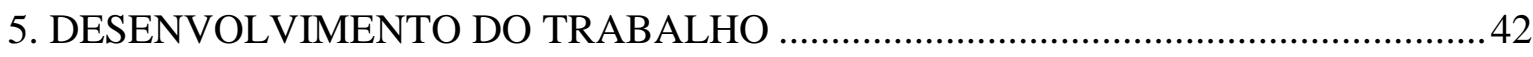

5.1. Base de dados do Sistema de Monitoração ........................................................... 43

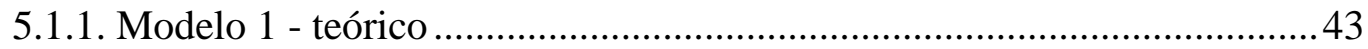

5.1.2. Modelo 2 - dados de operação do reator................................................. 44 
5.1.3. Modelo 3 - dados de operação do reator................................................... 44

5.1.4. Modelo 4 - dados de operação do reator................................................... 44

5.1.5. Modelo 5 - dados de operação do reator.................................................. 45



5.2.1.Nova estimativa das variáveis de entrada (GMDH + RNA) ..................... 45

5.2.2. Variáveis mais relevantes (RNA seleção) ............................................... 46

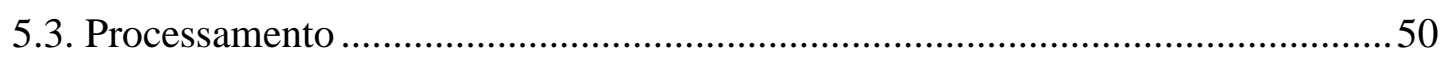

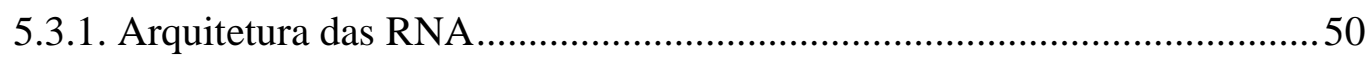



6.1. Nova estimativa das variáveis de entrada (GMDH + RNA) .............................52





6.1.2. Modelo 2 - dados de operação do reator ................................................ 60

6.1.2.1. Análise dos resultados obtidos...............................................65 65

6.2. Variáveis mais relevantes (RNA seleção) e Nova estimativa das variáveis de









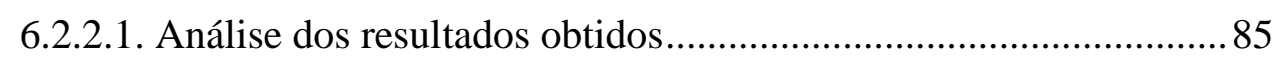



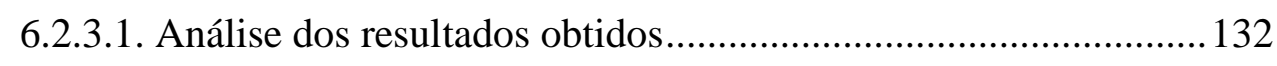



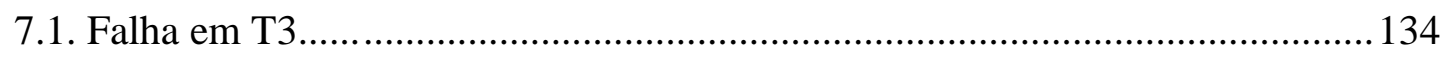

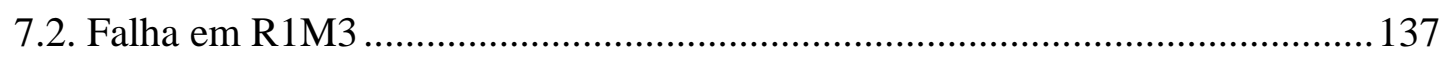












\section{LISTA DE TABELAS}

Tabela Título

Página



Tabela 2. Variáveis do modelo teórico do reator IEA-R1 ….............................................. 19

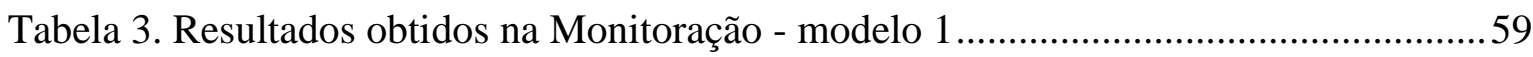

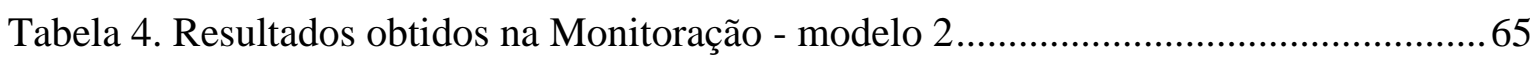

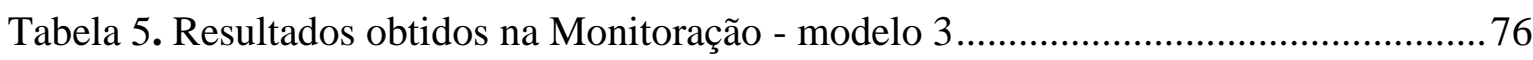



Tabela 7. Resultados obtidos na Monitoração - modelo 5................................................ 132

Tabela 8. Resíduos obtidos - Detecção de Falha em T3 .................................................. 137

Tabela 9. Resíduos obtidos - Detecção de Falha em R1M3 ............................................ 140

Tabela 10. Resíduos obtidos - Detecção de Falha em N2 ................................................ 143 


\section{LISTA DE FIGURAS}

Figura Título

Página

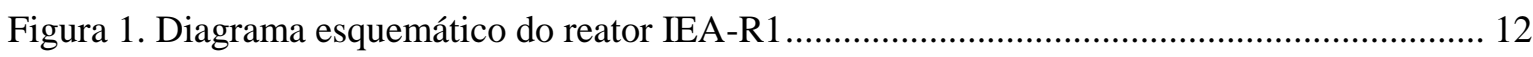



Figura 3. Estrutura do modelo auto-organizável GMDH com m entradas e k gerações.................. 21



Figura 5. Curva RMIN calculado a cada geração ..................................................................... 25



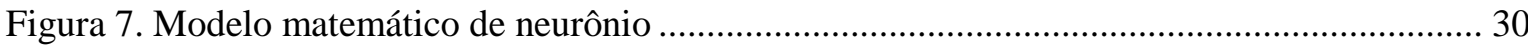



Figura 9. (a) Função limiar, (b) Função linear por partes (c) Função sigmóide com parâmetro de

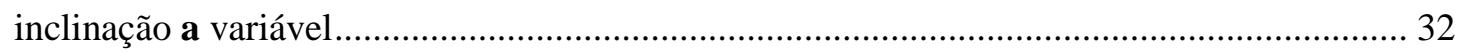

Figura 10. Redes com propagação para frente de uma camada .................................................... 33

Figura 11. Redes do tipo MLP (Camadas múltiplas com propagação para frente)........................... 34

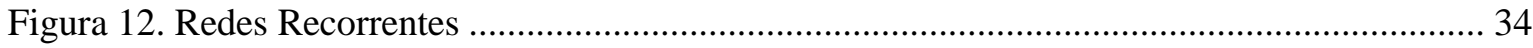

Figura 13. Resumo - implementação da metodologia desenvolvida ................................................. 42



Figura 15. Pré-processamento - estudo das variáveis mais relevantes ........................................... 47

Figura 16. Monitoração de N2 - Comparação entre as metodologias ............................................ 53





Figura 19. Monitoração de T3 - Comparação entre as metodologias............................................... 55

Figura 20. Monitoração de T4 - Comparação entre as metodologias................................................ 56

Figura 21. Monitoração de T6 - Comparação entre as metodologias.................................................. 56

Figura 22. Monitoração de T7 - Comparação entre as metodologias................................................ 57

Figura 23. Monitoração de T8 - Comparação entre as metodologias ................................................ 58

Figura 24. Monitoração de T9 - Comparação entre as metodologias................................................ 59

Figura 25. Monitoração de N2 - Comparação entre as metodologias ............................................. 61



Figura 27. Monitoração de T4 - Comparação entre as metodologias ............................................... 62

Figura 28. Monitoração de T7 - Comparação entre as metodologias.............................................. 63

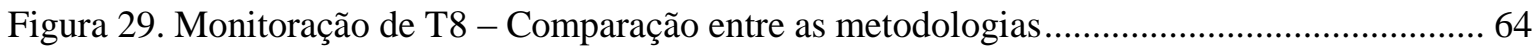



Figura 31. Monitoração de R1M3 - Comparação entre as metodologias .......................................... 65

Figura 32. Monitoração de N2 - Comparação entre as metodologias ............................................... 67 
Figura 33. Monitoração de T3 - Comparação entre as metodologias. 68

Figura 34. Monitoração de T4 - Comparação entre as metodologias................................................. 69

Figura 35. Monitoração de T7 - Comparação entre as metodologias................................................ 70

Figura 36. Monitoração de T8 - Comparação entre as metodologias................................................ 71

Figura 37. Monitoração de T9 - Comparação entre as metodologias............................................. 72

Figura 38. Monitoração de R1M3 - Comparação entre as metodologias ......................................... 73

Figura 39. Monitoração de R2M3 - Comparação entre as metodologias ........................................ 73

Figura 40. Monitoração de Z1 - Comparação entre as metodologias.............................................. 74

Figura 41. Monitoração de Z2 - Comparação entre as metodologias............................................... 75

Figura 42. Monitoração de Z3 - Comparação entre as metodologias................................................ 75

Figura 43. Monitoração de N2 - Comparação entre as metodologias .............................................. 78

Figura 44. Monitoração de T3 - Comparação entre as metodologias................................................. 78

Figura 45. Monitoração de T4 - Comparação entre as metodologias................................................ 79

Figura 46. Monitoração de T7 - Comparação entre as metodologias ............................................... 80

Figura 47. Monitoração de T8 - Comparação entre as metodologias.............................................. 80

Figura 48. Monitoração de T9 - Comparação entre as metodologias.............................................. 81

Figura 49. Monitoração de R1M3 - Comparação entre as metodologias ......................................... 82

Figura 50. Monitoração de R1M3 - Comparação entre as metodologias .......................................... 82

Figura 51. Monitoração de Z1 - Comparação entre as metodologias............................................... 83

Figura 52. Monitoração de Z2 - Comparação entre as metodologias................................................. 84

Figura 53. Monitoração de Z3 - Comparação entre as metodologias................................................ 85

Figura 54. Monitoração de N2 - Comparação entre as metodologias ............................................. 87

Figura 55.Saída desejada comparada à saída da rede com 8 neurônios na camada escondida ......... 88

Figura 56. Monitoração de N3 - Comparação entre as metodologias ............................................ 89

Figura 57. Saída desejada comparada à saída da rede com 8 neurônios na camada escondida ........ 89

Figura 58. Monitoração de N4 - Comparação entre as metodologias .............................................. 90

Figura 59. Saída desejada comparada à saída da rede com 5 neurônios na camada escondida ........ 91

Figura 60. Monitoração de N6 - Comparação entre as metodologias ............................................... 92

Figura 61. Saída desejada comparada à saída da rede com 10 neurônios na camada escondida ..... 92

Figura 62. Monitoração de N7 - Comparação entre as metodologias .............................................. 93

Figura 63. Saída desejada comparada à saída da rede com 9 neurônios na camada escondida ........ 94

Figura 64. Monitoração de N8 - Comparação entre as metodologias ............................................. 95

Figura 65. Saída desejada comparada à saída da rede com 9 neurônios na camada escondida ....... 95

Figura 66. Monitoração de T1 - Comparação entre as metodologias............................................... 96

Figura 67. Saída desejada comparada à saída da rede com 5 neurônios na camada escondida ........ 97

Figura 68. Monitoração de T2 - Comparação entre as metodologias................................................ 98

Figura 70. Monitoração de T3 - Comparação entre as metodologias................................................ 99 
Figura 71. Saída desejada comparada à saída da rede com 2 neurônios na camada escondida ..... 100

Figura 72. Monitoração de T4 - Comparação entre as metodologias............................................. 101

Figura 73. Saída desejada comparada à saída da rede com 10 neurônios na camada escondida ... 101

Figura 74. Monitoração de T6 - Comparação entre as metodologias.............................................. 102

Figura 75. Saída desejada comparada à saída da rede com 4 neurônios na camada escondida ..... 103

Figura 76. Monitoração de T7 - Comparação entre as metodologias............................................ 104

Figura 77. Saída desejada comparada à saída da rede com 6 neurônios na camada escondida ..... 104

Figura 78. Monitoração de T8 - Comparação entre as metodologias............................................ 105

Figura 79. Saída desejada comparada à saída da rede com 7 neurônios na camada escondida ..... 106

Figura 80. Monitoração de T9 - Comparação entre as metodologias............................................. 107

Figura 81. Saída desejada comparada à saída da rede com 5 neurônios na camada escondida .... 107

Figura 82. Monitoração de R1M3 - Comparação entre as metodologias ....................................... 108

Figura 83. Saída desejada comparada à saída da rede com 10 neurônios na camada escondida ... 109

Figura 84. Monitoração de R2M3 - Comparação entre as metodologias ....................................... 110

Figura 85. Saída desejada comparada à saída da rede com 8 neurônios na camada escondida ..... 110

Figura 86. Monitoração de R3M3 - Comparação entre as metodologias ....................................... 111

Figura 87. Saída desejada comparada à saída da rede com 8 neurônios na camada escondida ..... 112

Figura 88. Monitoração de R7M3 - Comparação entre as metodologias ....................................... 113

Figura 89. Saída desejada comparada à saída da rede com 10 neurônios na camada escondida ... 113

Figura 90. Monitoração de R8M3 - Comparação entre as metodologias ........................................ 114

Figura 91. Saída desejada comparada à saída da rede com 10 neurônios na camada escondida ... 115

Figura 92. Monitoração de R9M3 - Comparação entre as metodologias ....................................... 116

Figura 93. Saída desejada comparada à saída da rede com 3 neurônios na camada escondida ..... 116

Figura 94. Monitoração de R10M3 - Comparação entre as metodologias ...................................... 117

Figura 95. Saída desejada comparada à saída da rede com 8 neurônios na camada escondida ..... 118

Figura 96. Monitoração de R11M3 - Comparação entre as metodologias ...................................... 119

Figura 97. Saída desejada comparada à saída da rede com 10 neurônios na camada escondida ... 119

Figura 98. Monitoração de R12M3 - Comparação entre as metodologias ...................................... 120

Figura 99. Saída desejada comparada à saída da rede com 10 neurônios na camada escondida ... 121

Figura 100. Monitoração de R14M3 - Comparação entre as metodologias .................................... 122

Figura 101. Saída desejada comparada à saída da rede com 8 neurônios na camada escondida ... 122

Figura 102. Monitoração de Z1 - Comparação entre as metodologias .......................................... 123

Figura 103. Saída desejada comparada à saída da rede com 9 neurônios na camada escondida ... 124

Figura 104. Monitoração de Z2 - Comparação entre as metodologias ......................................... 125

Figura 105. Saída desejada comparada à saída da rede com 8 neurônios na camada escondida ... 125

Figura 106. Monitoração de Z3 - Comparação entre as metodologias .......................................... 126

Figura 107. Saída desejada comparada à saída da rede com 9 neurônios na camada escondida ... 127 
Figura 108. Monitoração de Z4 - Comparação entre as metodologias

Figura 109. Saída desejada comparada à saída da rede com 10 neurônios na camada escondida 128

Figura 110. Monitoração de C1 - Comparação entre as metodologias

Figura 111. Saída desejada comparada à saída da rede com 10 neurônios na camada escondida 130

Figura 112. Monitoração de C2 - Comparação entre as metodologias 131

Figura 113. Saída desejada comparada à saída da rede com 8 neurônios na camada escondida ... 131

Figura 114. Detecção de Falha em T3 - 5\% no valor lido 135

Figura 115. Detecção de Falha em T3 - 10\% no valor lido 135

Figura 116. Detecção de Falha em T3 - 15\% no valor lido 136

Figura 117. Detecção de Falha em T3 - 20\% no valor lido 136

Figura 118. Detecção de Falha em R1M3 - 5\% no valor lido 138

Figura 119. Detecção de Falha em R1M3 - 10\% no valor lido 138

Figura 120. Detecção de Falha em R1M3 - 15\% no valor lido 139

Figura 121. Detecção de Falha em R1M3 - 20\% no valor lido 139

Figura 122. Detecção de Falha em R1M3 - 5\% no valor lido 141

Figura 123. Detecção de Falha em R1M3 - 10\% no valor lido 141

Figura 124. Detecção de Falha em R1M3 - 15\% no valor lido. 142

Figura 125. Detecção de Falha em R1M3 - 20\% no valor lido 142 


\section{INTRODUÇÃO}

\subsection{Motivação para o trabalho}

Um aumento crescente na complexidade, eficiência e confiabilidade dos sistemas industriais modernos tem estimulado o desenvolvimento de sistemas de Monitoração e Detecção de Falhas [1] [15]. Isto se aplica de forma ainda mais acentuada nas centrais nucleares, onde os requisitos de segurança e confiabilidade são mais restritos do que em sistemas convencionais.

As tarefas de um sistema de Monitoração e Diagnóstico podem englobar desde a simples supervisão das variáveis, verificando se os seus valores estão dentro de um limite pré-estabelecido, até a Detecção de falhas. Sistemas de Monitoração e Diagnóstico mais sofisticados podem ainda realizar a identificação do componente responsável pela irregularidade observada no sistema (identificação de falhas). Em último caso, e desde que isso não comprometa o desempenho do processo, o sistema pode ainda gerar um sinal que irá substituir o sinal do sensor ou atuador falho, de forma que o processo possa continuar em andamento até a próxima manutenção programada.

Em sistemas de Monitoração e Diagnóstico de Falhas tradicionais utiliza-se a chamada redundância física (ou redundância por hardware), onde dois ou mais sensores similares realizam a mesma medida. Um esquema de votação lógica pode então ser utilizado para identificar um instrumento falho. Embora este seja um método confiável, há uma série de desvantagens, tais como o custo elevado de instalar e manter um maior número de sensores. Além disso, nem sempre há disponibilidade de espaço para a instalação de sensores redundantes, principalmente no caso de centrais nucleares.

Em oposição à redundância física (ou por hardware) tem-se a chamada redundância analítica (ou redundância por software) que faz uso da estimativa de sinais gerados por um modelo matemático do sistema considerado. Este modelo matemático pode ser elaborado a partir das equações matemáticas que descrevem o fenômeno real (conhecido como "first principle model"), ou o modelo é gerado a partir de uma base de dados ("data-driven model") [22]. 
Devido aos recentes avanços na computação, tem crescido muito o número de sistemas de monitoração baseados nessa nova metodologia. A principal vantagem do emprego de redundância analítica é que não há a necessidade de acrescentar novos componentes ao sistema existente para implementar o algoritmo de Monitoração e Detecção de Falhas. Normalmente, a instrumentação existente para controlar o processo é suficiente para isso.

A Detecção e o Diagnóstico antecipado de Falhas é uma tarefa extremamente importante, principalmente no que se refere a segurança da central nuclear e na redução dos custos de manutenção. As centrais nucleares modeRNA são extremamente complexas e frequentemente incluem diferentes tipos de sistemas que tentam compensar os efeitos das falhas e de componentes falhos, o que acaba dificultando a identificação da falha em seu estágio inicial [36].

As falhas podem ocorrer nos instrumentos de medição de forma independente ou simultaneamente. Quando ocorre uma falha simples, um circuito de alarme convencional é suficiente para realizar o diagnóstico, desde que o sinal do sensor não seja utilizado como entrada de outra variável de processo. Entretanto, nos processos industriais mais complexos é necessária a utilização de sistemas automáticos para auxiliar o operador na tomada de decisões [35].

As centrais nucleares são consideradas sistemas complexos em virtude do grande número de variáveis a serem observadas continuamente e da necessidade de se garantir bom desempenho e segurança. Durante uma falha, os operadores recebem um grande volume de informações através da leitura dos instrumentos, indicando um padrão típico desta anomalia. Devido à grande quantidade de informação em um período de tempo muito pequeno, os operadores são obrigados a tomar algumas decisões em condições estressantes dificultando, em alguns casos, o Diagnóstico da Falha. Com o propósito de auxiliar os operadores das centrais nucleares têm-se utilizado muitas técnicas de Inteligência Artificial, incluindo a Lógica Nebulosa [10], as Redes Neurais Artificiais (RNA) [29] [32], o GMDH (Group Method of Data Handling) [24][25] e os Algoritmos Genéticos (AG) [26] [29], na Monitoração e na Detecção de Falhas. A utilização desses métodos é justificada, por permitir a modelagem do processo sem o uso de equações algébricas que descrevam matematicamente o fenômeno [3] [14] [40]. Esta modelagem é realizada utilizando-se uma base de dados que contém o histórico temporal de operação do reator. 
O uso de RNA na solução de diversos problemas de engenharia justifica-se em relação a como estes problemas são representados internamente pela rede e também pelos resultados gerados. Em RNA, o procedimento usual na solução de problemas passa inicialmente por uma fase de aprendizagem, em que um conjunto de exemplos é apresentado para a rede, que representará a informação fornecida.

A possibilidade de aprender através de exemplos e generalizar a informação aprendida são, sem dúvida, as principais vantagens na solução de problemas através de RNA. A generalização, que está associada à capacidade da rede aprender através de um conjunto reduzido de exemplos, e posteriormente dar respostas coerentes para dados não conhecidos, é uma demonstração de que a capacidade das RNA não se limita apenas em mapear relações de entrada e saída. As RNA são capazes de representar informações não apresentadas de forma explícita, através de exemplos.

Nas aplicações onde se utiliza RNA existe uma grande preocupação quanto à seleção das variáveis de entrada da rede. Em uma sala de controle existem centenas de variáveis monitoradas que indicam o status de operação da instalação. Assim, a seleção adequada das variáveis mais representativas como entrada para as RNA é importante para que seja possível selecionar o menor número possível de variáveis representativas para o monitoramento da instalação. Normalmente deve-se recorrer ao conhecimento de um especialista na área para fazer tal seleção, ou realizar testes com várias combinações destas variáveis pré-selecionadas até que seja atingido um bom resultado. Por esse motivo, tornase interessante utilizar um método de seleção automática de entradas para as RNA, em outras palavras, uma seleção de variáveis que independa do prévio conhecimento do sistema em questão. Com isso, teremos RNA com arquiteturas mais compactas e eliminaremos a necessidade de utilização do conhecimento especialista para realizar esta tarefa [38].

Para a seleção automática das variáveis de entrada, Uhrig utilizou Algoritmos Genéticos (AG) no Diagnóstico de Falhas em reatores nucleares, obtendo bons resultados demonstrando assim a viabilidade de utilização deste método. Uhrig demonstrou ainda em seus estudos, que o uso de AG na seleção de entradas para as RNA demandavam um tempo computacional elevado [38].

Outro método que pode ser utilizado para a seleção automática das variáveis de entrada é o GMDH (Group Method of Data Handling). O GMDH é um algoritmo autoorganizável de propagação indutiva que permite a obtenção de um modelo matemático do sistema a partir de observações de amostras de dados (data-driven model) [6]. Além disso, 
o GMDH apresenta algumas vantagens, como: sua arquitetura evolui durante o processo de modelagem; auto-organização indutiva; não é uma técnica consumidora de tempo; e as variáveis de entrada não apropriadas para o modelo são excluídas automaticamente [24].

As duas técnicas mencionadas já foram usadas separadamente, onde foram desenvolvidos Sistemas de Monitoração e Detecção de Falhas em sensores utilizando Redes Neurais [4] e GMDH [24] aplicados ao reator de pesquisa do Ipen IEA-R1, demonstrando a sua viabilidade de aplicação para realizar tal tarefa, servindo como um suporte ao operador na tomada de decisões durante a operação do reator.

\subsection{Objetivo}

Este trabalho tem como principal objetivo o desenvolvimento de uma nova metodologia de Monitoração e Detecção de Falhas em sensores de centrais nucleares utilizando as metodologias GMDH e RNA de forma combinada, onde o GMDH será responsável pela seleção das variáveis de entrada para as RNA. Esta metodologia será aplicada no reator de pesquisas do IPEN IEA-R1, onde será utilizada uma base de dados contendo as informações das variáveis de processo, coletados e armazenados pelo SAD (Sistema de Aquisição de Dados) do reator.

A utilização do GMDH na seleção de entradas para as RNA recebeu o nome de pré-processamento. O pré-processamento foi realizado de duas formas distintas: na primeira, utilizou-se a matriz_z no treinamento das RNA, e na segunda decidiu-se investigar as variáveis mais relevantes para o GMDH em virtude dos bons resultados obtidos na primeira forma de pré-processamento realizado.

Para a monitoração dos instrumentos de processo, utilizaram-se Redes Neurais Artificiais (RNA's) com o propósito de realizar a modelagem das variáveis do sistema. Na detecção de falhas, também se utilizou Redes Neurais Artificiais, porém o modelo desenvolvido na monitoração foi testado com uma base de dados contendo falha.

A metodologia desenvolvida foi implementada inicialmente usando dados de um modelo teórico, e depois foram utilizados dados referentes a uma semana típica de operação do reator. O modelo teórico do reator IEA-R1 permite gerar dados para diferentes condições de operação, além de dados com falhas. Os dados gerados pelo modelo teórico, em diferentes condições de operação, permitiram a realização de um estudo exaustivo da metodologia de Redes Neurais na monitoração de instrumentos de processo. Após este estudo, foram utilizados dados referentes a uma semana típica de operação do reator, onde foram propostos quatro modelos, ou seja, diferentes combinações de variáveis. A função 
de monitoração é independente das indicações dos painéis de Instrumentação e Controle instalados na Sala de Controle, e, portanto a instalação do Sistema de Monitoração e Detecção de Falhas não irá interferir na operação do reator.

\subsection{Organização da tese}

* Capítulo 1: Neste capítulo é feita uma introdução, situando o tema da tese e definindo os objetivos do trabalho.

* Capítulo 2: São abordados os principais aspectos históricos das diferentes tecnologias utilizadas nos Sistemas de Monitoração e Detecção de Falhas.

* Capítulo 3: Descrição dos principais aspectos do reator IEA-R1 e da base de dados utilizadas no trabalho.

* Capítulo 4: Teoria das metodologias GMDH e Redes Neurais Artificiais.

* Capítulo 5: Desenvolvimento do trabalho, onde são descritas as etapas de realização deste trabalho.

- Capítulo 6: Resultados obtidos na monitoração dos sensores.

* Capítulo 7: Resultados obtidos na detecção de falhas dos sensores.

* Capítulo 8: Conclusões obtidas e também recomendações para trabalhos futuros. 


\section{REVISÃO BIBLIOGRÁFICA}

A bibliografia revisada apresenta trabalhos realizados na área de Monitoração e Detecção de Falhas utilizando técnicas de inteligência artificial, possibilitando assim o estabelecimento de um estudo sobre o estado da arte referente ao emprego das metodologias GMDH e RNA.

Em 1991, Uhrig [37] apresentou um estudo sobre a utilização de RNA na monitoração e no diagnóstico de falhas em reatores nucleares. Esse estudo envolveu uma série de aplicações, dentre as quais, será destacada o uso de RNA aplicadas na identificação de transientes. Para realizar tal tarefa, foram treinadas RNA distintas para diferentes tipos de transientes, ou seja, na ocorrência de um transiente X a RNA do tipo X será a responsável pela indicação do mesmo, e assim por diante. A metodologia foi implementada utilizando-se dados de um simulador de uma central nuclear para identificar sete transientes distintos. Os resultados obtidos mostraram que as redes treinadas conseguiram identificar a maioria dos transientes, antes do sistema de segurança desligar o reator.

Em 1992, Uhrig [38] utilizou AG na seleção das variáveis de entrada para as RNA. Os resultados obtidos foram satisfatórios e demonstraram a viabilidade de utilização de AG em problemas onde é necessário distinguir as variáveis mais relevantes sem o uso do conhecimento especialista.

Em 1993, Sorsa e Koivo (1993) [36] estudaram várias arquiteturas de redes para a monitoração e a detecção de falhas em um trocador de calor e em um tanque de mistura contínua. Foi utilizado um processo bem próximo do real como estudo de caso, onde existiam 14 medidas com ruído e 10 faltas típicas. Nesta aplicação, a melhor arquitetura foi a rede de Camadas Múltiplas (MLP) que foi capaz de identificar todas as falhas. 
Em 1994, Chung et. al. [5] desenvolveram um método de monitoração e detecção de falhas utilizando RNA, teoria de grafos e sistemas especialistas para sistemas de grande porte. O sistema desenvolvido permitia o diagnóstico de falhas nos regimes estacionário e transiente, utilizando para isto o conceito da propagação da falha ao longo do tempo. Para tanto, utilizou-se mapas auto-organizáveis como arquitetura das RNA. Este método foi implementado e testado na Planta Nuclear de Kori (na Coréia) em regime transiente.

Em 1995, Seliger e Frank [34] introduziram o conceito de RNA na detecção e no isolamento de falhas em processos industriais. Foram discutidas três possibilidades diferentes de utilização das RNA. A primeira possibilidade seria a utilização de uma RNA na obtenção de resíduos ao invés de um modelo matemático; a segunda seria o treinamento de uma RNA para realizar uma tarefa de classificação da evolução residual, e depois o isolamento da falha; a última possibilidade seria realizar a detecção em uma única etapa, onde a RNA seria treinada para detectar e isolar possíveis falhas de todas as medidas disponíveis. Os resultados obtidos através dessas três metodologias demonstraram a aplicabilidade destas para o isolamento de falhas em processos industriais.

Em 1999, Ferreira (1999) [8] desenvolveu uma metodologia robusta de detecção e isolamento de falhas em sensores, atuadores, controladores e outros instrumentos de campo, utilizando a metodologia GMDH. O GMDH foi utilizado para gerar a redundância analítica através da relação entre os diferentes componentes de um sistema. O uso da redundância analítica é necessário para detectar as anomalias do sistema e o isolamento de componentes falhos. Uma base de regras foi obtida através dos dados simulados pelo modelo GMDH, possibilitando assim o desenvolvimento de um sistema fuzzy para auxiliar o operador na tomada de decisões.

Em 2000, Simani e Fantuzzi (2000) [35] desenvolveram uma metodologia de monitoração de duas fases: na primeira fase, a falha era detectada com base nos resíduos gerados por um banco de filtros Kalman; na segunda, a identificação da falha era feita através de técnicas de reconhecimento de padrões, implementadas através de RNA. Essa metodologia foi aplicada a um modelo de turbina de gás industrial. Os resultados obtidos mostraram que as redes do tipo MLP obtiveram um bom desempenho para esta tarefa.

Em 2001, Rossi [28] usou redes do tipo MLP e Radial Basis Function (RBF) para a monitoração da potência do reator de pesquisas do Ipen IEA-R1, visando o desenvolvimento de uma interface homem-máquina inteligente, onde a informação fosse devidamente priorizada. Os resultados obtidos após o treinamento da rede foram mostrados 
em uma tela de informações, juntamente com o resultado obtido através de outras formas de medida de potência. A interface desenvolvida servirá como suporte aos operadores da instalação na eventual necessidade de calibração dos instrumentos medidores de Potência Nuclear.

Em 2002, Maki e Loparo [17] usaram uma rede do tipo MLP para a monitoração e detecção de falhas em processos industriais. Esta metodologia foi testada em uma estação de medidas complexas para realizar testes em um motor de indução. $\mathrm{O}$ principal aspecto desse estudo foi que a detecção de falhas ocorreu em regime transiente de operação do processo. Foi proposta uma RNA de dois estágios como estrutura básica do sistema de detecção. O primeiro estágio da rede detectava a direção dinâmica de cada medida; já o segundo detectava e monitorava as falhas. Este método conseguiu detectar e monitorar com grande sucesso as falhas treinadas em regime transiente.

Em 2003, Na et. al. [21] propuseram o uso de um modelo Fuzzy/Neural para estimar o sinal de saída através de sinais de entrada selecionados, além disso, foi utilizada a combinação da Análise de Correlação e AG para realizar a seleção automática das variáveis de entrada. O número ideal de regras fuzzy é obtido pelos AG integrado com a seleção de entrada automática. O sistema desenvolvido foi aplicado nas unidades 3 e 4 da central nuclear de Yonggwang. Os resultados obtidos mostraram que esse método de seleção de entradas associado a um modelo Fuzzy/Neural é capaz de monitorar um grande número de sensores em uma central nuclear.

Em 2003, Upadhyaya, Zhao e Lu [39] reuniram técnicas de GMDH, PCA (Análise de Componente Principal) e ANFIS (Sistema Neuro/Fuzzy de Inferência Adaptativa) para desenvolver um sistema de monitoração e detecção de falhas incipientes. Para ilustrar o desempenho do sistema desenvolvido foi utilizado um modelo teórico de gerador de vapor de um reator do tipo PWR. Os resultados obtidos mostraram que a metodologia desenvolvida conseguiu realizar a identificação de falhas incipientes, além disso, alterações nas condições de funcionamento da central nuclear foram apresentadas ao sistema ANFIS, para que ocorresse o aprendizado dessas novas condições.

Em 2004, Samanta [32] [33] utilizou AG e RNA na detecção de falhas em engrenagens de máquinas rotativas. Os AG foram utilizados para tornar a classificação do processo mais rápida e eficaz usando o menor número de variáveis que caracterizavam as condições do processo com o propósito de otimizar a estrutura das RNA. Os resultados obtidos demonstraram a viabilidade de utilização dos AG na extração de características para as RNA na Detecção de Falhas. 
Em 2006, Bueno [4] desenvolveu um sistema de Monitoração e Detecção de Falhas em sensores do reator IEA-R1 utilizando RNA, em três etapas: a primeira etapa foi dedicada à monitoração, a segunda à detecção e a terceira ao diagnóstico de falhas. As redes foram treinadas utilizando-se o algoritmo de retropropagação. Os resultados obtidos mostraram a viabilidade de aplicação de tal metodologia para realizar a monitoração e detecção de falhas em sensores.

Em 2006, Lo, Wong e Rad [16] desenvolveram um sistema inteligente para a monitoração e o diagnóstico de falhas em sistemas físicos dinâmicos. Para tanto, utilizouse BDG (Bond Direct Graph) integrado com técnicas de inteligência artificial e engenharia de controle para construir a base de conhecimento deste sistema. Os resultados obtidos mostraram a eficiência do sistema desenvolvido aplicados na monitoração e no diagnóstico de falhas.

Em 2006, Garcia [9] desenvolveu um sistema de Diagnóstico Automático de Falhas do tipo curto-circuito de baixa impedância em circuitos alimentadores de média tensão de sistemas reticulados de distribuição de energia elétrica. No diagnóstico ocorre a identificação do tipo de curto-circuito ocorrido e a sua localização, para tanto foi utilizada a metodologia de RNA. Os parâmetros para treinamento das RNA foram obtidos a partir de padrões de comportamento elétrico de curtos-circuitos monofásicos, bifásicos e trifásicos, obtidos através da simulação de um circuito de distribuição real localizado na cidade de Brasília, utilizando para isto o aplicativo ATP (Programa Alternativo de Transiente).

Em 2006, Pereira [24] desenvolveu um sistema de Monitoração e Diagnóstico de Falhas utilizando a metodologia GMDH aplicado ao reator IEA-R1. O sistema foi responsável pela monitoração das variáveis de operação, comparando os valores calculados pelo modelo GMDH com os valores medidos. A metodologia foi aplicada inicialmente em um modelo teórico do reator e, posteriormente em uma base de dados experimental contendo dados referentes a uma semana típica de operação do reator. O Diagnóstico de Falhas foi desenvolvido através da inserção de falhas sintéticas à base de dados, onde foram simuladas falhas nos sensores de temperatura, sendo implementado pela Lógica Nebulosa. Os resultados obtidos demonstraram a viabilidade de aplicação de tal metodologia no desenvolvimento de um sistema de Monitoração e Diagnóstico de Falhas aplicado em reatores nucleares.

Em 2009, Morales [20] utilizou redes bayesianas para o diagnóstico de falhas em sistemas flexíveis de manufatura. As redes bayesianas foram utilizadas para a 
representação das relações entre causa/efeito em uma condição de falha em um determinado componente do processo. Para realizar tal tarefa, primeiramente utilizou-se rede de Petri como uma ferramenta para a modelagem do sistema de controle, permitindo assim a realização de análises para assegurar o funcionamento do sistema de acordo com as especificações do processo produtivo. Esta proposta foi validada através do uso de redes bayesianas para o diagnóstico de falhas em uma célula combustível de hidrogênio. $\mathrm{O}$ diagnóstico foi realizado através da monitoração das seguintes variáveis: tensão, corrente elétrica, temperatura e umidade. O modelo foi construído através de dados estatísticos obtidos a partir do funcionamento simulado do sistema em questão. Os resultados obtidos demonstraram em todos os casos as verdadeiras causas da falha, verificando-se ainda, que é possível diagnosticar situações de falha antes que estas se propaguem através do sistema.

Em 2009, Rusinov et. al. [31] aplicou RNA de camadas múltiplas para realizar o diagnóstico de falhas em processos químicos. Para tanto, elaborou um modelo de RNA hierárquicas com a utilização de sistemas especialistas com o propósito de melhorar o modelo neural e a seleção do conjunto de dados para o treinamento da rede. No nível mais alto deste modelo hierárquico, a rede foi utilizada para a localização das falhas no processo, e no nível mais baixo utilizou-se um conjunto de redes para identicar as causas dessas falhas. Para reduzir a dimensão no nível mais alto da rede utilizou-se a técnica de Análise de Componente Principal (PCA). O conhecimento especialista foi utilizado para determinar o número de neurônios na camada de saída, sendo assim, o conjunto de treinamento apresentado para a RNA incluía projeções de valores nebulosos dos parâmetros de diagnóstico, que caracterizavam estados normais e falhos do processo. $\mathrm{O}$ modelo foi validado no processo de pirólise de hidrocarbonetos sendo obtidos bons resultados através da metodologia proposta.

Através da análise dos trabalhos apresentados neste capítulo, pode ser feita uma divisão destes em três grupos. O primeiro grupo é formado pelos trabalhos de monitoração e detecção de falhas usando RNA combinadas com outras técnicas de inteligência artificial sem a utilização de um método de seleção de variáveis de entrada [4] [5] [9] [16] [17] [20] [28] [34] [35] [36] [37]. Os resultados mostraram que a combinação de diferentes metodologias levou a uma melhoria nos resultados. O segundo grupo é formado pelos trabalhos que utilizam um método de seleção de entrada para as RNA [21] [31] [32] [33] [38]. A maioria utiliza algoritmos genéticos, porém a desvantagem observada é o tempo computacional elevado [32] [33]. Os resultados obtidos nesse trabalho mostraram a necessidade de utilizar uma outra metodologia na seleção de 
variáveis de entrada para as RNA, o que possibilitaria um estudo comparativo entre as diferentes metodologias. O terceiro grupo é formado pelos trabalhos de monitoração e detecção de falhas implementados através do algoritmo GMDH [8] [24] [39]. Os resultados obtidos nesses trabalhos mostraram que o algoritmo GMDH é capaz de fornecer uma melhor estimativa das variáveis de entrada, através da eliminação de informações redundantes. Todos esses trabalhos acabaram estimulando o uso do GMDH na seleção de entradas para as RNA, possibilitando assim o desenvolvimento de uma metodologia inédita de Monitoração e Detecção de Falhas em sensores de centrais nucleares. 


\section{PRINCIPAIS ASPECTOS DO REATOR IEA-R1}

\subsection{Descrição do Reator IEA-R1}

O Reator IEA-R1 foi projetado e construído pela "Babcok \& Wilcox", em 1956. É um reator tipo piscina, refrigerado e moderado a água leve, que utiliza berílio como refletor. Sua primeira criticalidade foi atingida em 16 de setembro de 1957, onde passou a operar a $2 \mathrm{MW}$ de potência, de segunda a sexta-feira, das 8:00h às 17:00h, com uma parada a cada 15 dias, às segundas-feiras, para manutenção preventiva e corretiva. A partir de 1995, o reator teve seu regime de operação modificado para 64 horas ininterruptas visando à produção de radioisótopos e o desenvolvimento de pesquisas. A Figura 1 apresenta um diagrama esquemático do reator IEA-R1.

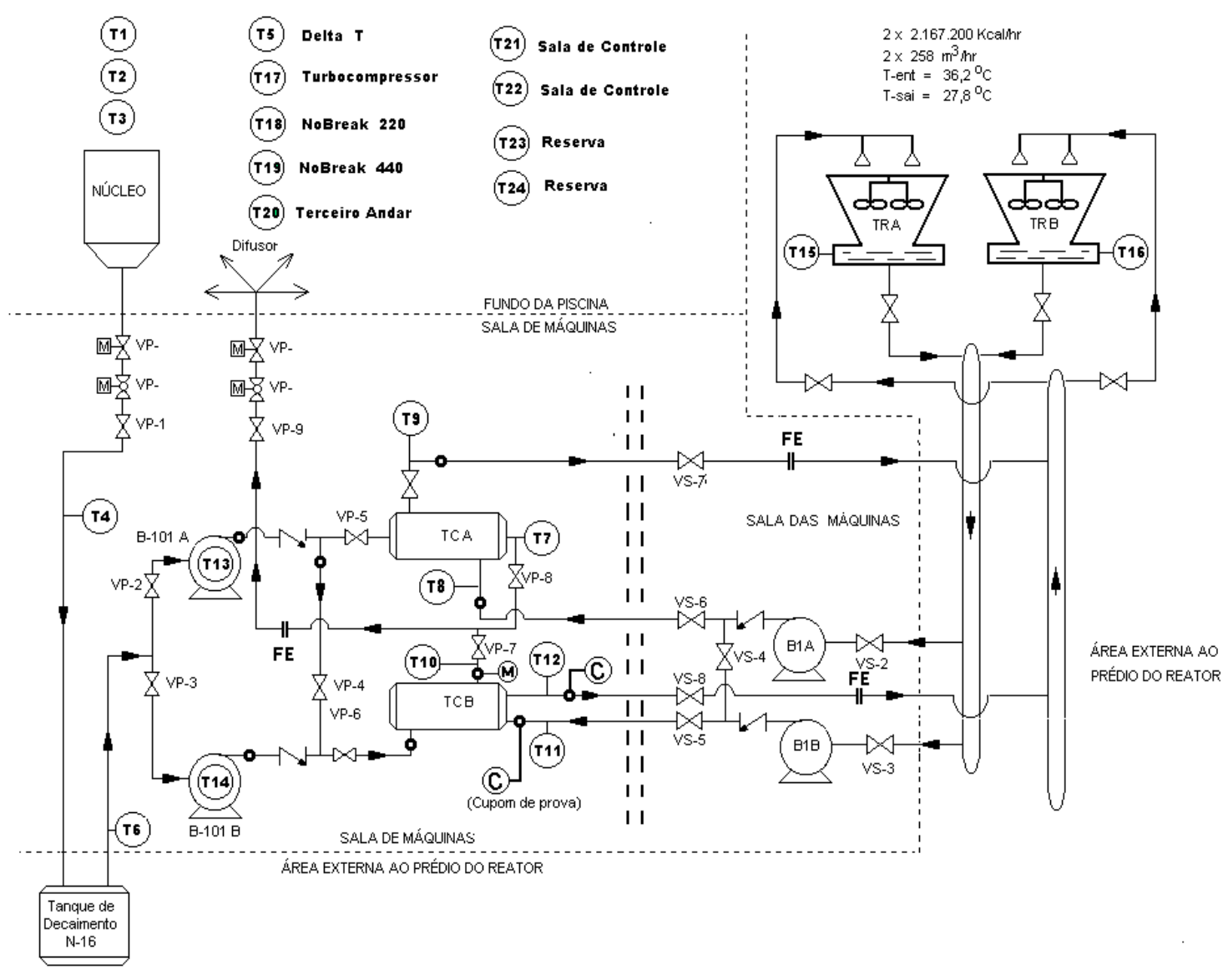

Figura 1. Diagrama esquemático do reator IEA-R1 
O reator IEA-R1 é utilizado para [27]:

Produção de radioisótopos para aplicações na medicina, indústria, agricultura e para pesquisas;

- Treinamento e formação de operadores de reatores;

Teste de materiais;

Pesquisa em física e química nuclear;

Realização de experimentos visando a obtenção de parâmetros nucleares

\subsubsection{Descrição da instalação}

O prédio do reator IEA-R1 é composto por cinco pavimentos:

No subsolo: a casa das máquinas;

* No $1^{o}$ andar: o salão de experimentos;

* No $2^{\circ}$ andar: sala de ventilação e ar-condicionado, almoxarifados e o acesso principal do prédio;

* No $3^{\circ}$ andar: saguão da piscina do reator, a sala de controle e as oficinas de apoio;

No $4^{o}$ andar encontra-se a sala de exaustão, com filtros e chaminé do sistema de exaustão do reator.

O núcleo do reator encontra-se dentro da piscina e está montado em uma placa matriz com oitenta orifícios, onde é possível posicionar os combustíveis em vários arranjos experimentais. Além disso, essa placa matriz é sustentada por uma treliça conectada a uma plataforma móvel, onde estão montados os quatro mecanismos de acionamento das barras e detectores que enviam sinais para a mesa de controle.

A piscina do reator é dividida em dois compartimentos: o segundo compartimento é destinado à operação do reator por conter o núcleo do mesmo; já o primeiro é usado para estocar e manusear materiais radioativos e elementos combustíveis.

A redundância física é utilizada nos circuitos de resfriamento do núcleo, onde apenas um circuito de resfriamento é suficiente para a operação e em caso de acidentes. Além disso, a maneira em que foram projetados permite alternar circuitos e alinhamentos dos seus diversos componentes.

Cada circuito de resfriamento é composto por: 
* 1 bomba do circuito primário;

* 1 bomba do circuito secundário;

* 1 trocador de calor;

* 1 torre de resfriamento do circuito secundário;

* Válvulas de fechamento automático são posicionadas na saída e no retorno da água da piscina, isolando a piscina do circuito primário em caso de acidente de perda do refrigerante, além disso, existe o sistema de resfriamento de emergência que permite o resfriamento do núcleo em caso de exposição.

O tanque de decaimento (localizado no circuito primário de resfriamento) é responsável por atrasar o retorno da água para a piscina, possibilitando o decaimento do ${ }^{16} \mathrm{~N}$ formado na água, após passagem através do núcleo.

A reatividade do reator é controlada usando-se três barras de segurança e uma barra de controle, que são movimentadas por um mecanismo de acionamento constituído de motores síncronos. Essas barras são sustentadas por magnetos que são desenergizados, na ocorrência de algum evento não usual, fazendo-as cair por ação da gravidade, desligando o reator.

A instrumentação nuclear é composta por:

* 2 câmaras de ionização não compensadas;

* 1 câmara de ionização compensada;

* 1 câmara de fissão.

Esses instrumentos nucleares enviam sinais para a mesa de controle localizada na sala de controle. Na sala de controle estão instalados os seguintes instrumentos de apoio à operação:

Monitores de radiação de área, dutos e contaminação de ar;

Sistema de alarmes de radiação;

* Comando das bombas dos circuitos: primário e secundário, e os ventiladores das torres de resfriamento;

* Comandos do sistema de ventilação e exaustão do ar-condicionado;

* Alarme de incêndio; 
- Comando do sistema de resfriamento de emergência;

- Comando das válvulas de isolação do circuito primário;

* Iluminação de emergência;

* Indicação de condutividade da água da piscina e da água de reposição;

* Sistema de análise de vibração dos mancais dos volantes de inércia;

* Comunicação interna e externa.

O sistema de ventilação e ar-condicionado é responsável por manter o prédio com pressão levemente negativa nas áreas com maior risco de contaminação, tais como: saguão da piscina, casa de máquinas e salão de experimentos.

A água da piscina do reator mantém-se em boa qualidade através do uso de sistemas de resinas trocadoras de íons, que são os sistemas de tratamento e retratamento da água. O sistema de tratamento é responsável por completar o nível da piscina com água de pureza necessária aos níveis operacionais; já o sistema de retratamento opera continuamente e tem como objetivo manter a qualidade da água da piscina, minimizando os efeitos de corrosão e os níveis de dose de radiação na superfície da piscina.

A energia elétrica é fornecida por meio da rede elétrica da concessionária local, e se ocorrer uma interrupção no fornecimento de energia, um conjunto de quatro motogeradores fornecerá energia elétrica aos sistemas vitais e essenciais para manter o reator em operação.

Além disso, os principais sistemas do reator enviam sinais à mesa de controle, garantindo que ocorra o desligamento, na ocorrência de alguma anormalidade durante a operação.

Todos os aspectos de instalação descritos acima têm como objetivo garantir a segurança máxima do reator IEA-R1, protegendo assim os indivíduos, a sociedade e o meio ambiente de acidentes nucleares.

\subsection{Sistema de Aquisição de Dados (SAD)}

O Sistema de Aquisição de Dados SAD é responsável pela monitoração de 58 variáveis operacionais, incluindo temperatura, vazão, nível, pressão, radiação, potência nuclear e posição de barras. O SAD permite armazenar a história temporal de todas as variáveis de processo monitoradas, fornecendo assim um conjunto de informações que foram utilizados para a elaboração do Sistema de Monitoração e Detecção de Falhas. A Tabela 1 apresenta as variáveis monitoradas pelo SAD: 
Tabela 1. Variáveis monitoradas pelo SAD

\begin{tabular}{|c|c|c|}
\hline Variável & Descrição & $\begin{array}{l}\text { Unidade de } \\
\text { medida }\end{array}$ \\
\hline $\mathrm{Z} 1$ & Posição da barra de controle & {$[\mathrm{mm}]$} \\
\hline $\mathrm{Z} 2$ & Posição da barra de segurança 1 & {$[\mathrm{~mm}]$} \\
\hline $\mathrm{Z3}$ & Posição da barra de segurança 2 & {$[\mathrm{~mm}]$} \\
\hline $\mathrm{Z4}$ & Posição da barra de segurança 3 & {$[\mathrm{~mm}]$} \\
\hline N1 & Período [seg] & [seg] \\
\hline $\mathrm{N} 2$ & $\%$ de potência (canal de segurança 1$)$ & [\%] \\
\hline N3 & \% de potência (canal de segurança 2 ) & [\%] \\
\hline N4 & \% de potência (canal de segurança 3 ) & {$[\%]$} \\
\hline N5 & Potência logarítmica (canal log) & [\%] \\
\hline N6 & \% de potência (canal linear) & [\%] \\
\hline N7 & $\%$ de demanda (modo automático) & [\%] \\
\hline N8 & Potência do N16 (canal N16) & [\%] \\
\hline F1M3 & Vazão do primário & [gpm] \\
\hline F2M3 & Vazão do secundário (trocador A) & [gpm] \\
\hline F3M3 & Vazão do secundário (trocador B) & [gpm] \\
\hline F23 & Vazão de água de emergência & [gpm] \\
\hline DP & Delta P do núcleo & [V] \\
\hline $\mathrm{C} 1$ & Condutividade da água da piscina após o tratamento & [ $\mu \mathrm{mho}]$ \\
\hline $\mathrm{C} 2$ & $\begin{array}{l}\text { Condutividade da água da piscina antes da entrada no sistema } \\
\text { de retratamento }\end{array}$ & [ $\mu \mathrm{mho}]$ \\
\hline L1 & Nível da piscina & [\%] \\
\hline R1M3 & $\begin{array}{l}\text { Taxa de dose localizada na ponte de sustentação do núcleo, } \\
\text { lado esquerdo }\end{array}$ & {$[\mathrm{mR} / \mathrm{h}]$} \\
\hline R2M3 & $\begin{array}{l}\text { Taxa de dose localizada na ponte de sustentação do núcleo, } \\
\text { lado direito }\end{array}$ & {$[\mathrm{mR} / \mathrm{h}]$} \\
\hline R3M3 & $\begin{array}{l}\text { Taxa de dose localizada na parede do prédio do saguão da } \\
\text { piscina, face norte }\end{array}$ & {$[\mathrm{mR} / \mathrm{h}]$} \\
\hline R4M3 & $\begin{array}{l}\text { Taxa de dose localizada na parede da piscina, face sul, sobre o } \\
\text { tubo de irradiação } n^{\circ} 8\end{array}$ & {$[\mathrm{mR} / \mathrm{h}]$} \\
\hline
\end{tabular}




\begin{tabular}{|c|c|c|}
\hline Variável & Descrição & $\begin{array}{c}\text { Unidade de } \\
\text { medida }\end{array}$ \\
\hline R5M3 & $\begin{array}{l}\text { Taxa de dose localizada na parede da piscina, face oeste, sobre } \\
\text { os tubos de irradiação }{ }^{\circ} 3 \text { e } 4\end{array}$ & {$[\mathrm{mR} / \mathrm{h}]$} \\
\hline R6M3 & $\begin{array}{l}\text { Taxa de dose localizada na parede do prédio do reator, face } \\
\text { leste, sobre os tubos de armazenamento de material radioativo }\end{array}$ & {$[\mathrm{mR} / \mathrm{h}]$} \\
\hline R7M3 & $\begin{array}{l}\text { Taxa de dose localizada no poço de coleta de água da piscina } \\
\text { (poço SUMP) }\end{array}$ & {$[\mathrm{mR} / \mathrm{h}]$} \\
\hline R8M3 & $\begin{array}{l}\text { Taxa de dose localizada no sistema de retratamento de água - } \\
\text { Coluna de resinas }\end{array}$ & {$[\mathrm{mR} / \mathrm{h}]$} \\
\hline R9M3 & Taxa de dose localizada no trocador de calor A & {$[\mathrm{mR} / \mathrm{h}]$} \\
\hline R10M3 & $\begin{array}{l}\text { Taxa de dose localizada na parede ao fundo do porão, } \\
\text { encostada ao duto de exaustão entre os trocadores de calor A e } \\
\text { B }\end{array}$ & [cps] \\
\hline R11M3 & $\begin{array}{l}\text { Taxa de dose localizada na sala do ar condicionado, junto ao } \\
\text { duto de exaustão de ar do } 1^{\circ} \text { andar }\end{array}$ & [cps] \\
\hline R12M3 & $\begin{array}{l}\text { Taxa de dose localizada no saguão da piscina, junto ao duto de } \\
\text { exaustão de ar }\end{array}$ & [cps] \\
\hline R13M3 & Taxa de dose localizada no duto de exaustão de ar da chaminé & [cps] \\
\hline R14M3 & Taxa de dose localizada no tanque de retenção & [cps] \\
\hline T1 & Temperatura na superfície da piscina & {$\left[{ }^{\circ} \mathrm{C}\right]$} \\
\hline $\mathrm{T} 2$ & Temperatura a meia altura da piscina & {$\left[{ }^{\circ} \mathrm{C}\right]$} \\
\hline T3 & Temperatura sobre o núcleo do reator & {$\left[{ }^{\circ} \mathrm{C}\right]$} \\
\hline T4 & Temperatura na entrada do tanque de decaimento & {$\left[{ }^{\circ} \mathrm{C}\right]$} \\
\hline T5 & Temperatura delta T (T4-T3) & {$\left[{ }^{\circ} \mathrm{C}\right]$} \\
\hline T6 & Temperatura na saída do tanque de decaimento & {$\left[{ }^{\circ} \mathrm{C}\right]$} \\
\hline T7 & Temperatura na saída do primário (trocador A) & {$\left[{ }^{\circ} \mathrm{C}\right]$} \\
\hline T8 & Temperatura na entrada do secundário (trocador A) & {$\left[{ }^{\circ} \mathrm{C}\right]$} \\
\hline T9 & Temperatura na saída do secundário (trocador A) & {$\left[{ }^{\circ} \mathrm{C}\right]$} \\
\hline $\mathrm{T} 10$ & Temperatura na saída do primário (trocador B) & {$\left[{ }^{\circ} \mathrm{C}\right]$} \\
\hline T11 & Temperatura na entrada do secundário (trocador B) & {$\left[{ }^{\circ} \mathrm{C}\right]$} \\
\hline T12 & Temperatura na saída do secundário (trocador B) & {$\left[{ }^{\circ} \mathrm{C}\right]$} \\
\hline T13 & Temperatura na carcaça do motor da bomba B101-A & {$\left[{ }^{\circ} \mathrm{C}\right]$} \\
\hline
\end{tabular}




\begin{tabular}{|l|l|c|}
\hline Variável & Descrição & $\begin{array}{c}\text { Unidade de } \\
\text { medida }\end{array}$ \\
\hline T14 & Temperatura na carcaça do motor da bomba B102-A & {$\left[{ }^{\circ} \mathrm{C}\right]$} \\
\hline T15 & Temperatura externa na torre de refrigeração A & {$\left[{ }^{\circ} \mathrm{C}\right]$} \\
\hline T16 & Temperatura externa na torre de refrigeração B & {$\left[{ }^{\circ} \mathrm{C}\right]$} \\
\hline T17 & Temperatura na carcaça do motor do turbo compressor & {$\left[{ }^{\circ} \mathrm{C}\right]$} \\
\hline T18 & Temperatura no NO-BREAK -220V & {$\left[{ }^{\circ} \mathrm{C}\right]$} \\
\hline T19 & Temperatura no NO-BREAK $-440 \mathrm{~V}$ & {$\left[{ }^{\circ} \mathrm{C}\right]$} \\
\hline T20 & Temperatura ambiente & {$\left[{ }^{\circ} \mathrm{C}\right]$} \\
\hline T21 & Temperatura ambiente & {$\left[{ }^{\circ} \mathrm{C}\right]$} \\
\hline T22 & Temperatura ambiente & {$\left[{ }^{\circ} \mathrm{C}\right]$} \\
\hline T23 & Temperatura ambiente & {$\left[{ }^{\circ} \mathrm{C}\right]$} \\
\hline T24 & Temperatura ambiente & {$\left[{ }^{\circ} \mathrm{C}\right]$} \\
\hline
\end{tabular}

\subsection{Modelo Teórico do reator IEA-R1}

Com o objetivo de iniciar os estudos de Monitoração e Detecção de Falhas usando GMDH e Redes Neurais Artificiais, foi utilizado um modelo teórico do reator IEAR1, elaborado utilizando-se a ferramenta GUIDE do Matlab [23]. A ferramenta GUIDE é composta por um conjunto de funções projetadas para desenvolver interfaces de forma fácil e rápida. Além disso, esta ferramenta possibilita o desenvolvimento de interfaces com gráficos e botões que executam determinadas funções do Matlab quando são pressionados.

O modelo teórico do reator é uma ferramenta que permite gerar dados em diversas condições de operação do reator, permitindo trabalhar com situações que não são possíveis de se obter experimentalmente, devido às restrições de operação do reator nuclear.

Este modelo representa as relações básicas entre as diferentes variáveis de processo. O reator IEA-R1 possui dois circuitos de refrigeração, e neste modelo foi representado apenas um circuito de refrigeração. As equações que regem o comportamento das variáveis de processo foram baseadas no balanço de massa e energia do reator IEA-R1, levando-se em consideração todos os aspectos físicos e operacionais, tais como, comprimento e diâmetro das tubulações, relações entre os valores de vazão, temperaturas e perda de carga [23]. Na Tabela 2, segue uma descrição das variáveis do reator IEA-R1 representadas no modelo teórico. 
Tabela 2. Variáveis do modelo teórico do reator IEA-R1

\begin{tabular}{|l|l|}
\hline Variável & Descrição \\
\hline T1 & Temperatura na superfície da piscina $\left[{ }^{\circ} \mathrm{C}\right]$ \\
\hline T2 & Temperatura a meia altura da piscina $\left[{ }^{\circ} \mathrm{C}\right]$ \\
\hline T3 & Temperatura sobre o núcleo do reator $\left[{ }^{\circ} \mathrm{C}\right]$ \\
\hline T4 & Temperatura na entrada do tanque de decaimento $\left[{ }^{\circ} \mathrm{C}\right]$ \\
\hline T6 & Temperatura na saída do tanque de decaimento $\left[{ }^{\circ} \mathrm{C}\right]$ \\
\hline T7 & Temperatura na saída do primário $\left[{ }^{\circ} \mathrm{C}\right]$ \\
\hline T8 & Temperatura na entrada do secundário $\left[{ }^{\circ} \mathrm{C}\right]$ \\
\hline T9 & Temperatura na saída do secundário $\left[{ }^{\circ} \mathrm{C}\right]$ \\
\hline FE01 (mp) & Vazão do primário $($ gpm $)$ \\
\hline FE02 (ms) & Vazão do secundário $(\mathrm{gpm})$ \\
\hline
\end{tabular}

A interface do programa foi criada de forma a lembrar o fluxograma de processo do reator IEA-R1 (Figura 2). Nessa interface é possível visualizar os valores da potência térmica (em MW), calculados no núcleo e no lado primário do trocador de calor.

Neste modelo é possível adicionar falhas às variáveis, sendo que a escolha das variáveis com falha é feita a partir de uma lista que contêm todas as variáveis do modelo. Existe ainda a opção de gerar dados "sem falha", ou seja, na condição normal de operação do reator.

Pode-se ainda atribuir níveis de ruídos das variáveis de entrada através de uma janela, sendo o seu valor determinado em \%.

Além disso, é possível determinar o número total de pontos que serão gerados para as condições estabelecidas, onde o programa calcula para um ponto, atualiza os valores necessários, e reinicia o cálculo para o próximo ponto.

Para gerar uma base de dados, pode-se digitar diretamente os valores desejados nas caixas de edição da interface, e em seguida pressionar o botão calcular, onde será calculado o valor da potência de acordo com as equações do balanço térmico. 


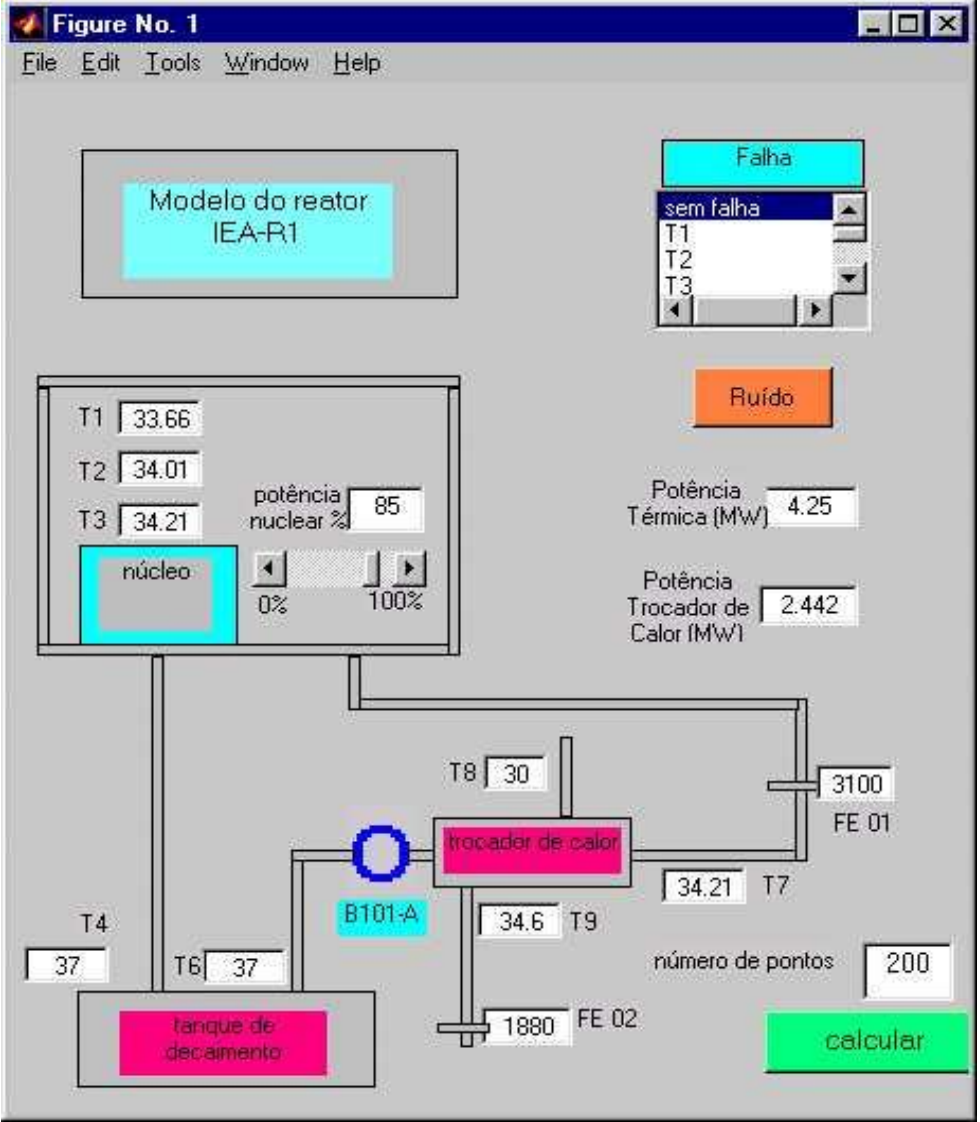

Figura 2. Interface do programa desenvolvido 


\section{FUNDAMENTOS TEÓRICOS}

\subsection{Group Method of Data Handling (GMDH)}

O GMDH é um modelo algébrico auto-organizável, baseado em um aprendizado sequencial de redes. Essas redes são funções matemáticas que caracterizam relações complexas e lineares de uma forma compacta e de rápida execução. Uma característica bem interessante dessas redes é a divisão do problema em subconjuntos e a aplicação de técnicas de mapeamento avançado para resolver cada um desses subconjuntos de problemas simples [22].

A rede polinomial que é construída através do algoritmo GMDH, é um modelo adaptativo e de aprendizado supervisionado. A arquitetura desta rede é formada durante o processo de treinamento (modelo não-paramétrico). A função de ativação é baseada em um elemento polinomial de ordem arbitrária, onde os valores estimados são propagados sucessivamente para gerações superiores do algoritmo, melhorando a cada estágio sucessivo, como pode ser observado na Figura 3.

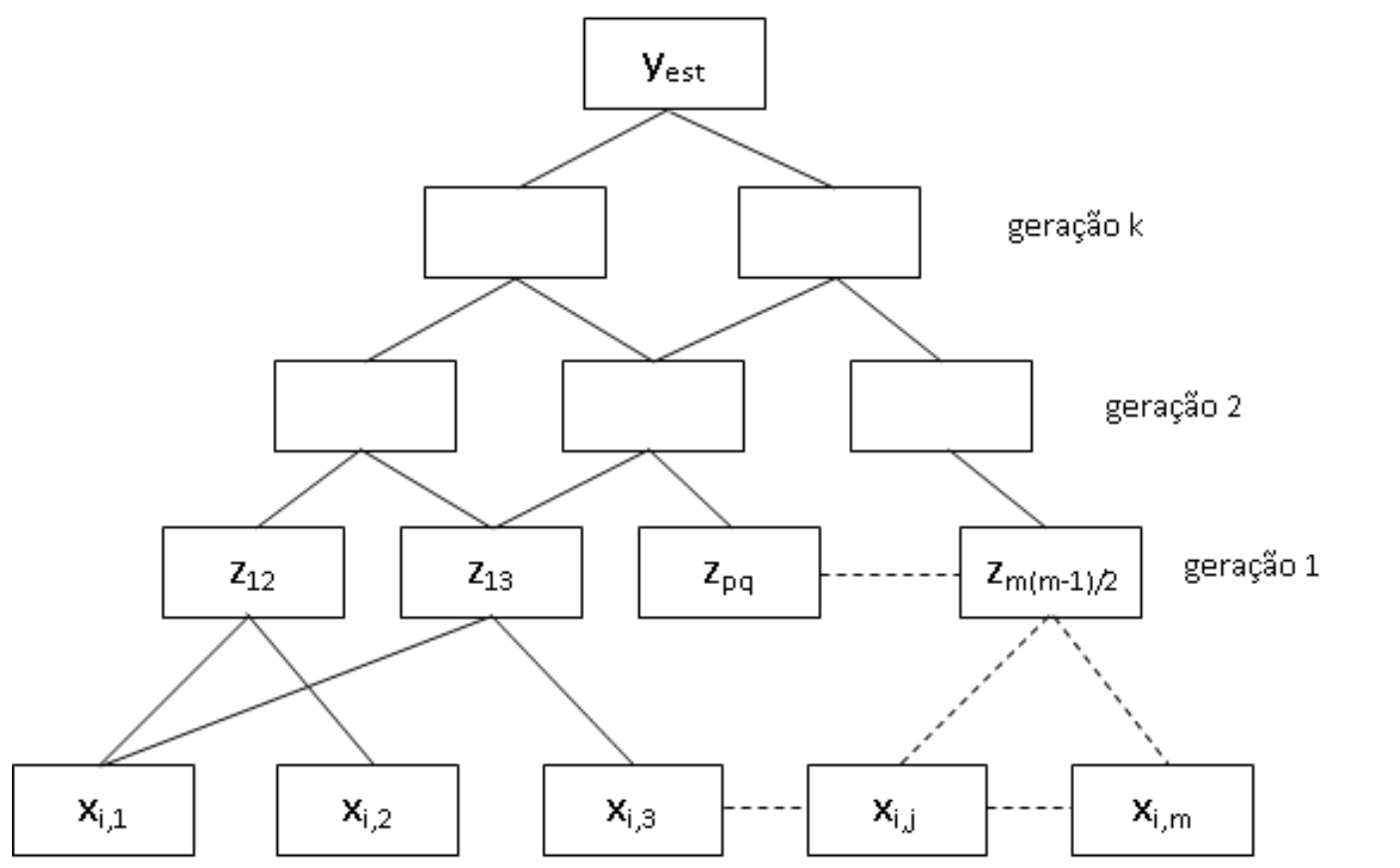

Figura 3. Estrutura do modelo auto-organizável GMDH com m entradas e k gerações 
Cada nó de saída pode ser expresso por uma função polinomial de segunda ordem como é mostrado na Figura 4, onde:

$\mathrm{x}_{\mathrm{i}}$ e $\mathrm{x}_{\mathrm{j}}$ : entradas

* A, B, C, D, E e F: coeficientes polinomiais, equivalentes aos pesos da rede

* Y: nó de saída

O algoritmo de treinamento GMDH pode ser utilizado para ajustar os coeficientes polinomiais e para encontrar a arquitetura da rede.
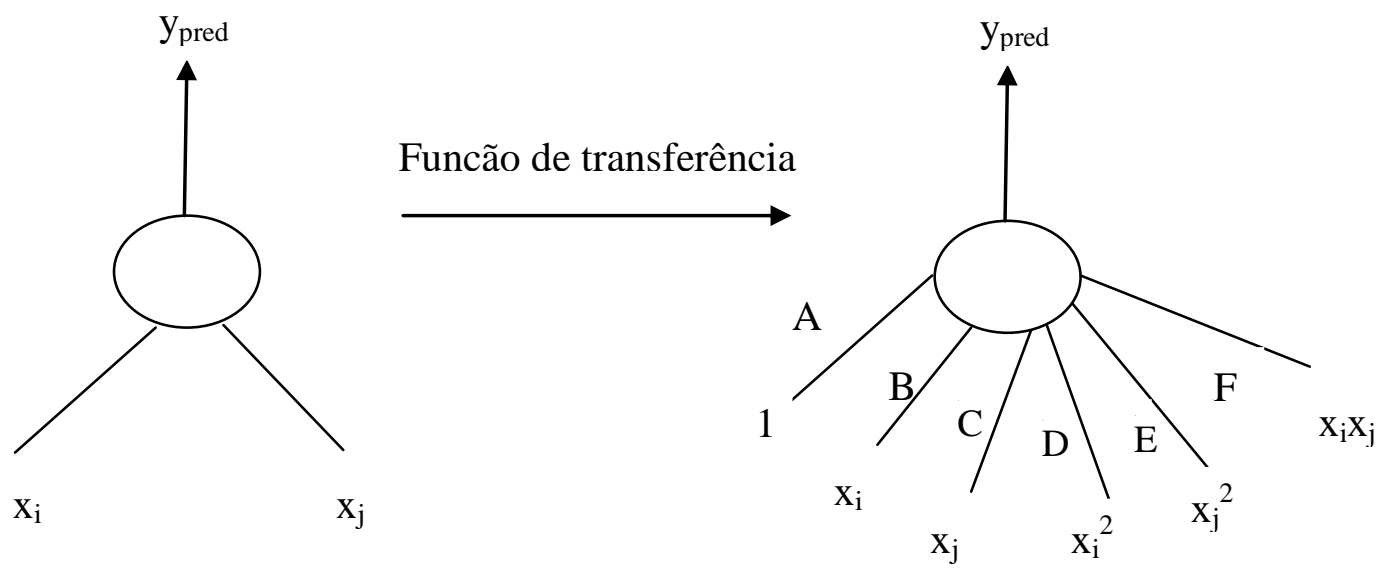

Figura 4. Nó do algoritmo GMDH

Os componentes do vetor de entrada podem ser variáveis independentes, formas funcionais ou termos de diferenças finitas. Outras funções lineares podem ser utilizadas, como diferenças probabilísticas, harmônicas e funções logísticas. O método permite encontrar simultaneamente a estrutura do modelo e a dependência da variável de saída do sistema através dos valores mais significantes das variáveis de entrada.

\subsection{Descrição da metodologia GMDH}

Em geral, os dados disponíveis são as variáveis de entrada e de saída de um sistema, representadas pela matriz de variáveis de entrada $X=\left(x_{i j}\right)$, e pelo vetor da variável de saída $\mathrm{Y}=\left(\mathrm{y}_{\mathrm{ij}}\right), \mathrm{i}=1,2, \ldots, \mathrm{n}$ e $\mathrm{j}=1,2, \ldots, \mathrm{m}$ onde $\mathrm{n}$ é o número total de observações e m é o número total de variáveis. 
$\mathbf{X}=\left[\begin{array}{ccccc}\mathbf{x}_{11} & \mathbf{x}_{12} & \ldots & \ldots & \mathbf{x}_{\mathbf{1 m}} \\ \mathbf{x}_{21} & \mathbf{x}_{22} & \ldots & \ldots & \mathbf{x}_{\mathbf{2 n}} \\ \cdots & \cdots & \cdots & \mathbf{x}_{\mathbf{i j}} & \cdots \\ \cdots & \cdots & \cdots & \cdots & \cdots \\ \mathbf{x}_{\mathbf{n} 1} & \mathbf{x}_{\mathbf{n}} & \cdots & \cdots & \mathbf{x}_{\mathbf{n m}}\end{array}\right] \quad Y=\left[\begin{array}{c}y_{1} \\ y_{2} \\ \cdots \\ y_{i} \\ \cdots \\ y_{n}\end{array}\right]$

O algoritmo GMDH é executado de acordo com os seguintes passos:

$1^{\mathrm{o}}$ passo. O primeiro passo consiste em construir um novo conjunto de variáveis Z. Para tanto, inicialmente deve-se dividir as observações em dois subconjuntos distintos. O primeiro subconjunto será utilizado para ajuste ( $\mathrm{i}=1$ até nt) e o segundo para verificação $(i=n t+1$ até $n)$.

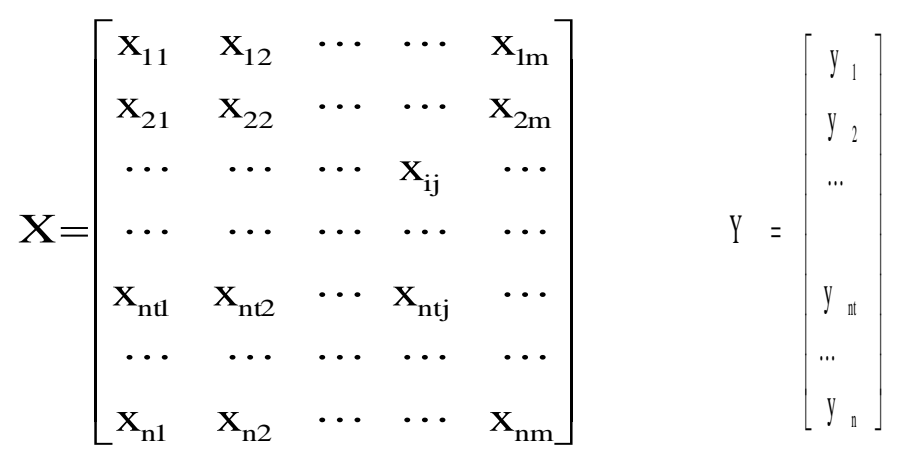

A seguir tomam-se as variáveis independentes do subconjunto de ajuste duas de cada vez para todas as combinações possíveis e calculam-se os coeficientes da seguinte regressão polinomial, onde p e q são as colunas da matriz X:

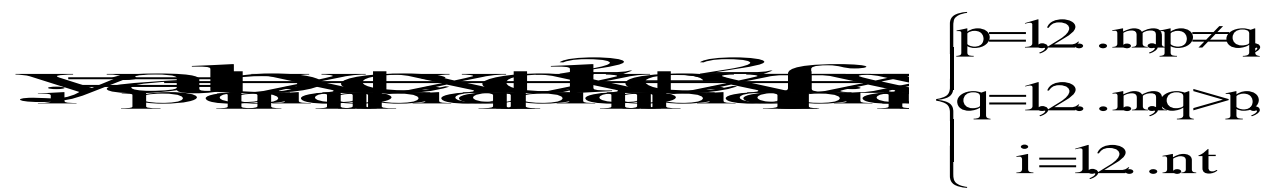

Para cada combinação das variáveis independentes (colunas de X) há um conjunto de coeficientes da regressão, resultando na matriz de coeficientes C. Como se tem $\mathrm{m}(\mathrm{m}-1) / 2$ diferentes combinações das variáveis de entrada, resultam $\mathrm{m}(\mathrm{m}-1) / 2$ linhas da matriz de coeficientes $\mathrm{C}$.

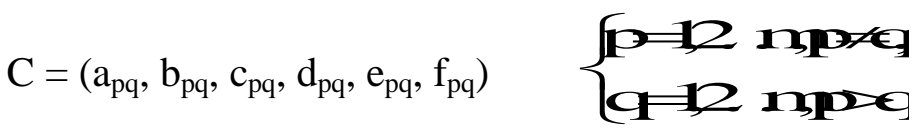


Para cada conjunto de coeficientes $\mathrm{C}_{\mathrm{pq}}$, avalia-se o polinômio para todos os $\mathrm{n}$ pontos de dados para calcular uma nova estimativa de $\mathrm{y}$, chamada $\mathrm{z}_{\mathrm{pq}}$ :

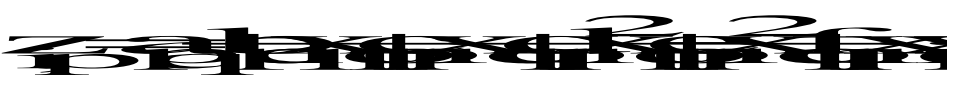

Esses novos valores são armazenados na primeira coluna de uma matriz Z .

Repete-se esta avaliação para todos os conjuntos de coeficientes e para todos os $\mathrm{n}$ dados, gerando uma nova matriz $\mathrm{Z}$ chamada nova geração de variáveis.

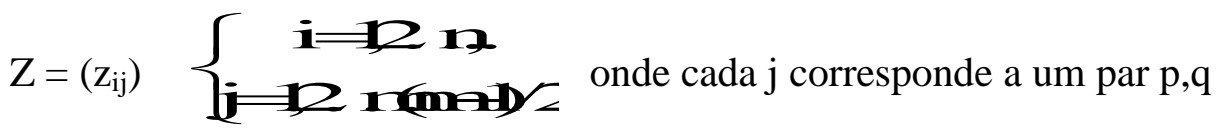

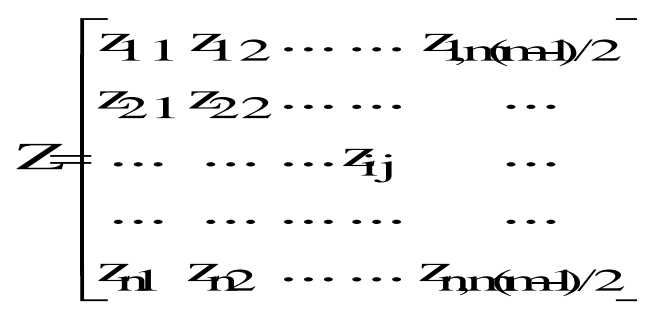

Podem-se interpretar estas variáveis (matriz Z) como novas variáveis que têm melhor poder de estimativa do que aquelas da geração original (matriz X).

$2^{\circ}$ passo. O próximo passo é comparar cada coluna de $\mathrm{Z}$ com a variável dependente $\mathrm{Y}$. Isto é, para cada coluna $\mathrm{j}$ de $\mathrm{Z}$ calcula-se o desvio médio quadrático $\mathrm{r}_{\mathrm{j}}$ para $\mathrm{i}$ variando de nt+1 até n, ou seja, utilizando o subconjunto de verificação:

$r_{j}^{2}=\frac{\sum_{i=n t+1}^{n}\left(y_{i}-z_{i j}\right)^{2}}{\sum_{i=n t+1}^{n} y_{i}^{2}} \quad j=1,2, \ldots m(m-1) / 2$

Ordena-se as colunas de $\mathrm{Z}$ em ordem crescente de $\mathrm{r}_{\mathrm{j}}$ e então seleciona-se aquelas colunas de $\mathrm{Z}$ que satisfaçam um critério selecionado anteriormente (por exemplo $\mathrm{r}_{\mathrm{j}}<\mathrm{R}$, onde $\mathrm{R}$ é um valor residual mínimo). Pode-se notar que o número de variáveis salvas, digamos $\mathrm{m}_{1}$, pode ser igual, menor ou maior do que o número original $\mathrm{m}$.

$3^{\circ}$ passo. Esta nova matriz $\mathrm{Z}$ irá substituir a matriz original $\mathrm{X}$. Estas novas variáveis são combinadas exatamente como se fez anteriormente. Ou seja, calculam-se 
todas as equações de regressão quadráticas de y em função destas novas variáveis (duas a duas). Isso irá fornecer um novo conjunto de $m_{1}\left(m_{1}-1\right) / 2$ equações de regressão para estimar y a partir das novas variáveis. Agora são selecionadas as melhores das novas estimativas, gerando novas variáveis independentes a partir das equações selecionadas para substituir as anteriores, e combinar todos os pares destas novas variáveis.

$4^{\mathrm{o}}$ passo. Do passo anterior encontra-se o menor $r_{j}$ e chama-se de RMIN. Se o valor de RMIN é menor que o valor de RMIN da geração prévia, repete-se os passos 1, 2 e 3. Se o valor de RMIN é maior que o valor precedente, assume-se que a "curva RMIN" atingiu seu mínimo, o processo é interrompido e usam-se os resultados da geração anterior. A Figura 5 apresenta um exemplo desse tipo de situação. Na geração 6 o RMIN teve um valor maior que o seu precedente (geração 5), portanto o processo foi interrompido e foram utilizados os resultados da geração 5 .

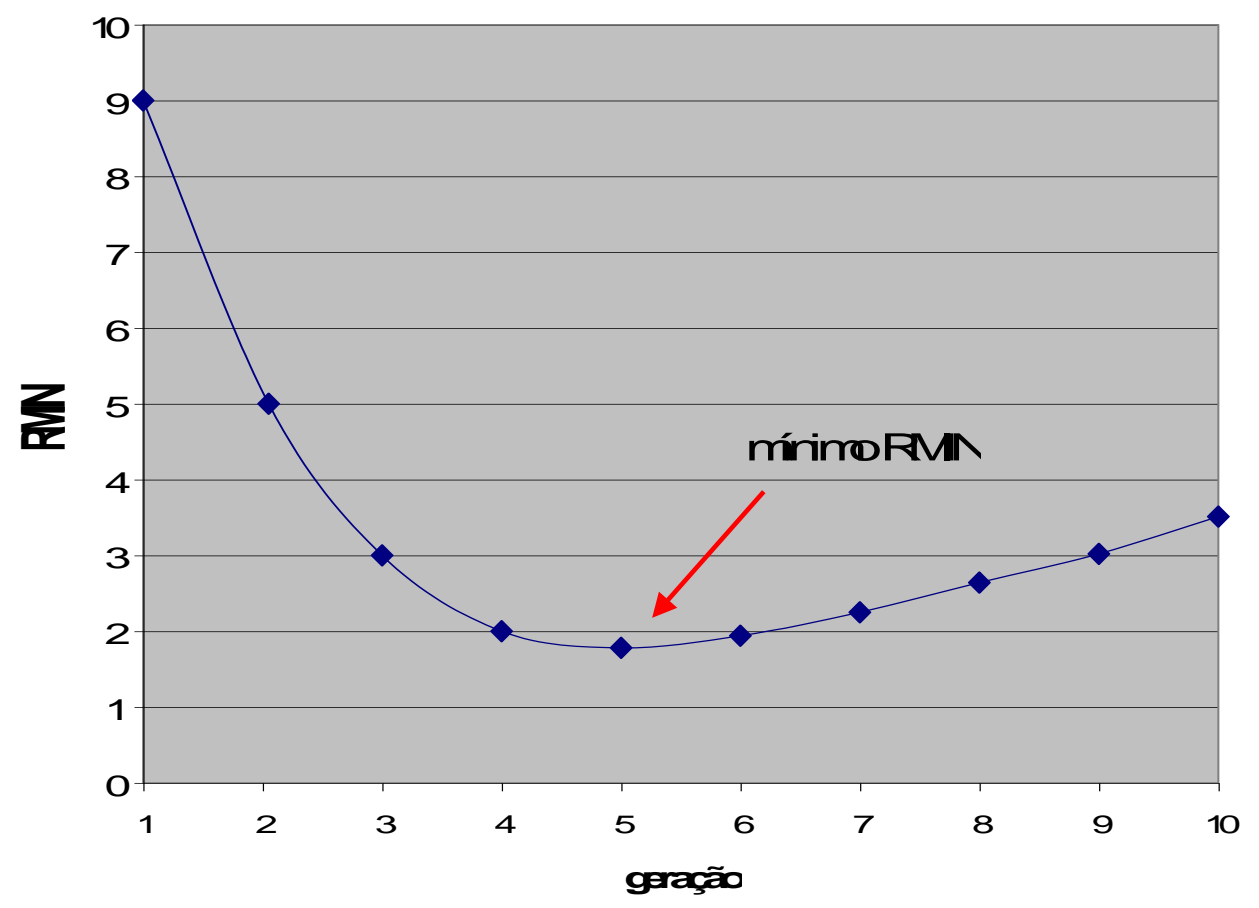

Figura 5. Curva RMIN calculado a cada geração

A primeira coluna da matriz $\mathrm{Z}$ conterá os valores de $\mathrm{y}_{\mathrm{i}}$ do polinômio de Ivakhnenko avaliados para os $\mathrm{n}$ pontos de dados originais. Em outras palavras, a primeira coluna de $\mathrm{Z}$ é a estimativa da variável dependente. Para encontrar os coeficientes $\mathrm{a}, \mathrm{b}_{\mathrm{i}}, \mathrm{c}_{\mathrm{ij}}$, $\mathrm{d}_{\mathrm{ijk}}, \ldots$ no polinômio de Ivakhnenko, deve-se salvar todos os conjuntos de coeficientes de todas as gerações que foram computados a cada iteração e sistematicamente avaliar esta 
árvore de quadráticos até chegar em um polinômio de alta ordem das variáveis originais $\mathrm{x}_{1}$, $\mathrm{x}_{2}, \ldots \mathrm{x}_{\mathrm{m}}$. De um ponto de vista computacional, desde que se tenham todos os polinômios de regressão quadráticos armazenados no computador, é possível computar a estimativa da saída y a partir destes termos armazenados [6] [8].

\subsection{Redes Neurais Artificiais (RNA)}

\subsubsection{Introdução}

Os estudos em neurofisiologia têm desvendado vários mecanismos sobre o fluxo e o processamento de informações que ocorrem no cérebro humano. Alguns destes mecanismos foram modelados matematicamente permitindo a elaboração de algoritmos computacionais que simulam, ainda que de modo simplificado, a mais básica das estruturas cerebrais: o neurônio.

A capacidade de implementar computacionalmente versões simplificadas de neurônios biológicos deu origem a uma subespecialidade da inteligência artificial, conhecida como Redes Neurais Artificiais (RNA), que podem ser definidas como sistemas paralelos compostos por unidades de processamento simples, dispostas em camadas e altamente interligadas, inspiradas no cérebro humano [12]. A origem da teoria de RNA remonta aos modelos matemáticos e aos modelos de engenharia de neurônios biológicos. Os neurônios biológicos podem ser divididos em três seções: o corpo celular (soma), os dendritos e o axônio, como mostra a Figura 6 [2].

No corpo celular (soma), as informações são processadas e novos impulsos nervosos são gerados;

* No axônio, os impulsos nervosos são transmitidos a outros neurônios;

* Os dendritos recebem os impulsos nervosos, provenientes de outros neurônios, e os conduz até o corpo celular. O ponto de contato entre a terminação axônica de um neurônio e o dendrito de outro neurônio é denominado sinapse. 


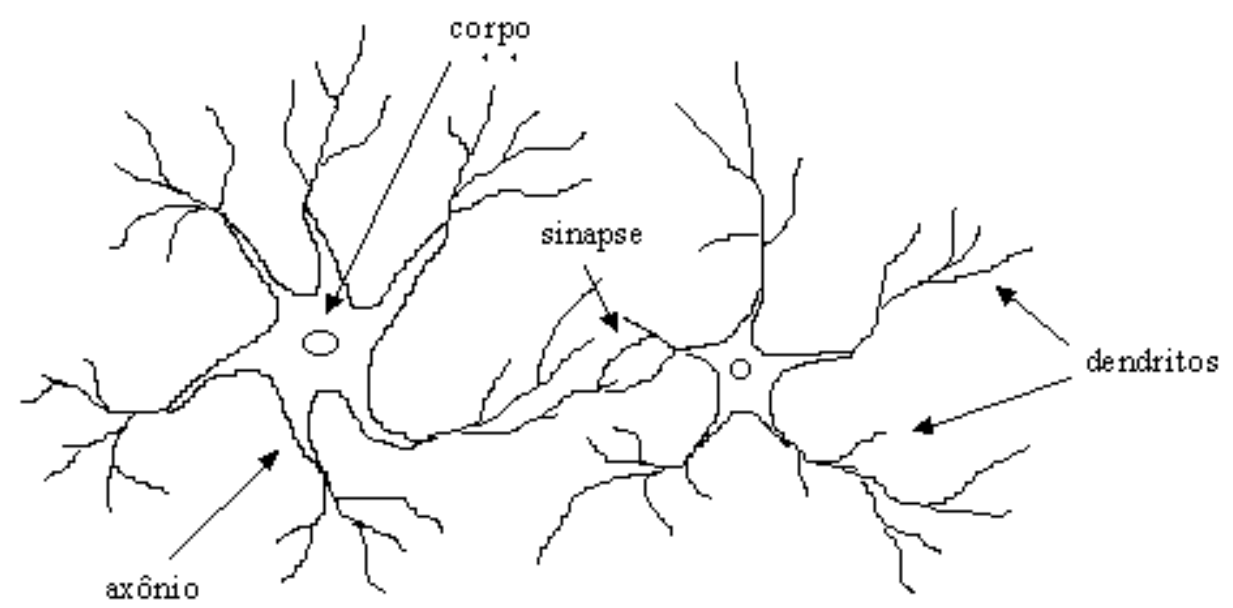

Figura 6. Neurônio Biológico

A sinapse é o ponto da estrutura de uma rede de neurônios através da qual ocorrem os processos de comunicação entre os mesmos, por meio de processos eletroquímicos específicos decorrentes de características particulares da sua constituição.

As sinapses são regiões eletroquimicamente ativas, compreendidas entre duas membranas celulares: a membrana pré-sináptica e a membrana pós-sináptica. Na membrana pré-sináptica chegam estímulos provenientes de uma outra célula; e a póssináptica, é a membrana do dendrito. O estímulo nervoso que chega à sinapse, nesta região, é transferido à membrana dendrital pelos neurotransmissores. Essa transferência provoca uma alteração no potencial elétrico da membrana pós-sináptica. A conexão sináptica poderá ser excitatória ou inibitória, dependendo do neurotransmissor. $\mathrm{Na}$ conexão excitatória ocorrerá uma alteração no potencial da membrana, que contribuirá para a formação de um impulso nervoso no axônio de saída, enquanto que a conexão inibitória agirá no sentido oposto.

\subsubsection{Aspectos Históricos}

O início das pesquisas na área de Redes Neurais Artificiais teve início após a publicação de um artigo intitulado "A logical calculus of the ideas immanent in nervous activity (Um cálculo lógico das idéias imanentes na atividade nervosa)”, por Mc Culloch e Pitts [19], onde foi proposto um modelo simplificado de neurônio biológico, que em um determinado instante de tempo, ficaria ativo ou inativo. O trabalho de Mc Culloch e Pitts propiciou uma disseminação do entendimento de possíveis modelos neurais, atraindo e influenciando muitos pesquisadores famosos. 
Hebb, em 1949, publicou um livro intitulado "The Organization of Behavior (A Organização do Comportamento)" onde foi proposta pela primeira vez uma regra de aprendizagem para a modificação dos pesos sinápticos [13].

Em 1956, John Von Neumann introduziu o conceito de redundância, originando a geração dos atuais computadores digitais [12].

Rosenblatt, em 1958, forneceu várias idéias a respeito do Perceptron. Entre 1960 e 1962, Rosenblatt e seu grupo de pesquisas estavam concentrados no problema do treinamento do Perceptron, onde conseguiram provar a convergência de um algoritmo de aprendizado [12].

Widrow e Hoff (1960) desenvolveram um modelo neural denominado Adaline “Adaptive Linear Element (Elemento Linear Adaptativo)”. Com ele definiram, em 1962, uma das primeiras redes construídas com elementos adaptativos, o Madaline "Multiple Adaline (Múltiplos Adalines)”. O Adaline/Madaline usou saídas lineares ao invés das binárias originalmente propostas por Mc Culloch e Pitts. Adicionalmente, Widrow e Hoff desenvolveram um algoritmo de aprendizado de grande importância na área das Redes Neurais, utilizando o conceito de minimização do desvio médio quadrático (Least Mean Square algorithm - LMS). Esta técnica ficou conhecida como regra delta ou método do gradiente descendente para a minimização do erro [12].

Em 1969, Minsky e Papert lançaram o polêmico livro Perceptrons, onde foi demonstrado matematicamente que o teorema desenvolvido por Rosenblatt só era aplicável a problemas linearmente separáveis. Ainda neste mesmo trabalho, Minsky e Papert afirmaram que não havia motivo aparente para acreditar que redes formadas por múltiplas camadas de Perceptrons, pudessem herdar as boas qualidades do Perceptron simples. Estas colocações desestimularam os pesquisadores que atuavam na área, fazendo com que houvesse um grande desinteresse pelas pesquisas na área de Redes Neurais durante a década de 70 e início dos anos 80 [12].

Apesar das poucas atividades de pesquisa nesse período, alguns trabalhos tiveram destaque, especialmente as redes auto-organizáveis, como foi o caso do trabalho de Kohonen (1972) [7] que desenvolveu modelos de memórias associativas, utilizando o conceito de aprendizado competitivo, nos quais as unidades competem entre si para responder a determinada entrada, e a unidade vencedora tem os pesos de sua entrada modificados, convergindo para responder com mais força a valores próximos do desejado [12]. 
Em 1976, Grossberg estabeleceu os princípios para uma nova classe de redes neurais junto com Carpenter denominadas de ART (Teoria de Ressonância Adaptativa) [7].

Hopfield (1982) utilizou a idéia de uma função energia para uma nova maneira de funcionamento das redes recorrentes com conexões sinápticas simétricas, onde os elementos são ligados buscando o aprendizado com um mínimo de energia, tendo dado origem às Redes de Hopfield [12].

Somente em 1986 tiveram início as atividades de desenvolvimento de Redes Neurais Artificiais, com o desenvolvimento do algoritmo de retropropagação por Rumelhart, Hinton e Williams, embora este algoritmo já tivesse sido proposto em 1974, por Werbos em sua tese de doutorado; e por Parker e LeCun (1985). Com o lançamento do livro denominado Parallel Distributed Processing: Explorations in the Microstructures of Cognition, editado por Rumelhart e McClelland, o qual apresenta de uma forma organizada todo o progresso das redes neurais, ressurgiu o grande interesse pelas pesquisas nessa área [30].

\subsubsection{Modelo matemático de neurônio}

Em 1943, Warren McCulloch e Walter Pitts propuseram o primeiro modelo matemático de neurônio [19]. O neurônio de McCulloch era um dispositivo binário, sendo que sua saída poderia ser pulso ou não pulso, e suas entradas tinham ganhos arbitrários, podendo ser excitatórias ou inibitórias. Na Figura 7 temos a representação do modelo proposto por McCulloch e Pitts.

Neste modelo, podem-se identificar três elementos básicos: um conjunto de sinapses, onde um sinal $x_{j}$ na entrada da sinapse $j$, conectada ao neurônio $k$, é multiplicado por um peso sináptico $w_{k j}$; um somador que é responsável pela somatória dos sinais de entrada que são multiplicados pelos respectivos pesos sinápticos dos neurônios; e de uma função de ativação para limitar a amplitude da saída do neurônio. O bias - " $b_{k}$ ", tem como objetivo promover um deslocamento de curva da função de ativação, ou seja, aumentar ou diminuir a entrada da função de ativação. 


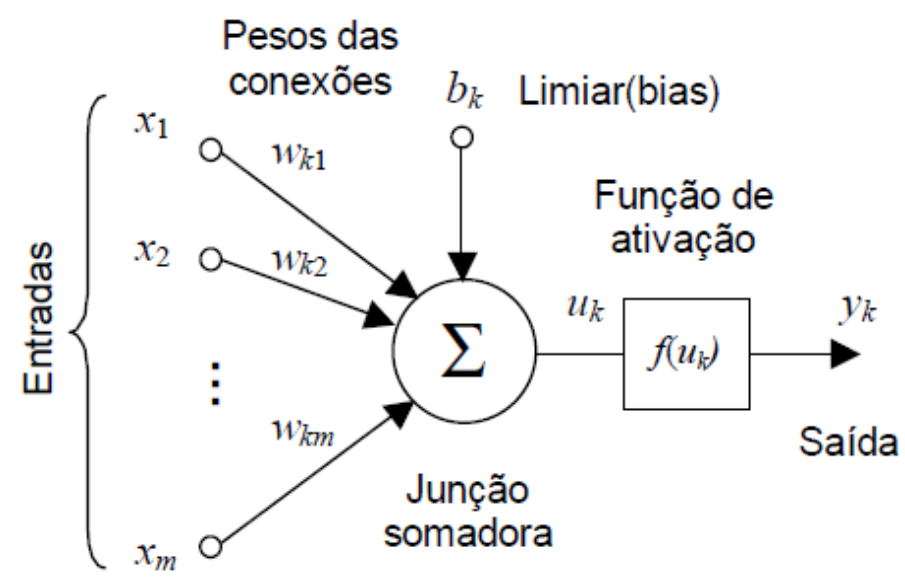

Figura 7. Modelo matemático de neurônio

Em termos matemáticos, podemos descrever o neurônio $k$ através das equações (9) e (10):

$$
\begin{aligned}
& \mu_{k}=\sum_{j=1}^{m} w_{k j} x_{j} \\
& y_{k}=\varphi\left(u_{k}+b_{k}\right)
\end{aligned}
$$

Onde $x_{1}, x_{2}, \ldots, x_{m}$ são os sinais de entrada; $w_{k 1}, w_{k 2}, \ldots, w_{k m}$ são os pesos sinápticos do neurônio $k ; u_{k}$ é o integrador linear de saída devido aos sinais de entrada; $b_{k}$ é o bias; $\varphi_{k}($.$) é a função de ativação; e y_{k}$ é o sinal de saída do neurônio. O bias tem o papel de promover uma transformação afim à saída $u_{k}$ do combinador linear do neurônio, como pode ser visto na equação (11):

$$
v_{k}=u_{k}+b_{k}
$$

Se o bias $b_{k}$ for positivo ou negativo, a relação entre o potencial de ativação $v_{k}$ do neurônio $k$ e do integrador de saída $u_{k}$ é modificado de acordo com a Figura 8. 


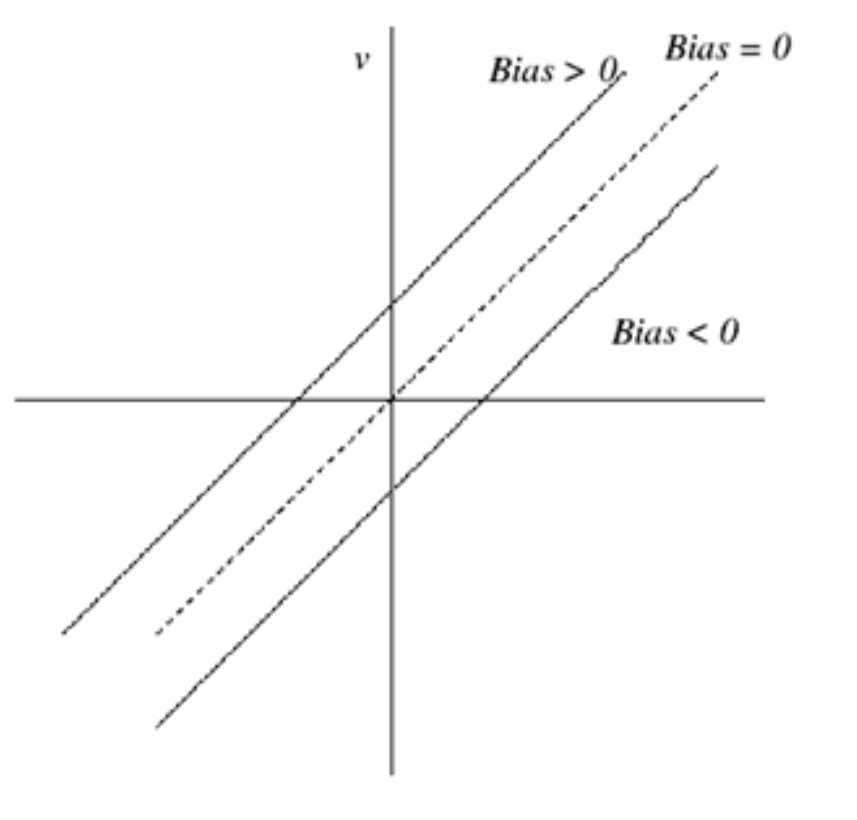

Figura 8. Transformação afim produzida pelo bias

Na Figura 9 são apresentados exemplos de funções de ativação:

- Função de limiar: A saída do neurônio é igual a zero, quando seu valor for negativo e 1, quando seu valor for positivo, como mostra a Figura 9a.

$$
\varphi(v)=\left\{\begin{array}{l}
1 \text { se } v \geq 0 \\
0 \text { se } v<0
\end{array}\right.
$$

- Função de limiar por partes: Esse tipo de função pode ser visto como uma aproximação de um amplificador não linear, como mostra a Figura $9 b$.

$$
\varphi(v)=\left\{\begin{array}{cc}
1, & v \geq 0,5 \\
v, & -0,5>v>0,5 \\
0, & v \leq 0,5
\end{array}\right.
$$

- Função sigmóide: É o tipo de função de ativação mais utilizada em redes neurais artificiais. É definida como uma função crescente, que apresenta um balanço entre o comportamento linear e não-linear, como 
pode ser visto na Figura 9c. Um exemplo de função sigmóide é a função logística, definida pela equação (14):

$$
\varphi(v)=\frac{1}{1+e^{-a v}}
$$

Onde a é o parâmetro de inclinação da função.

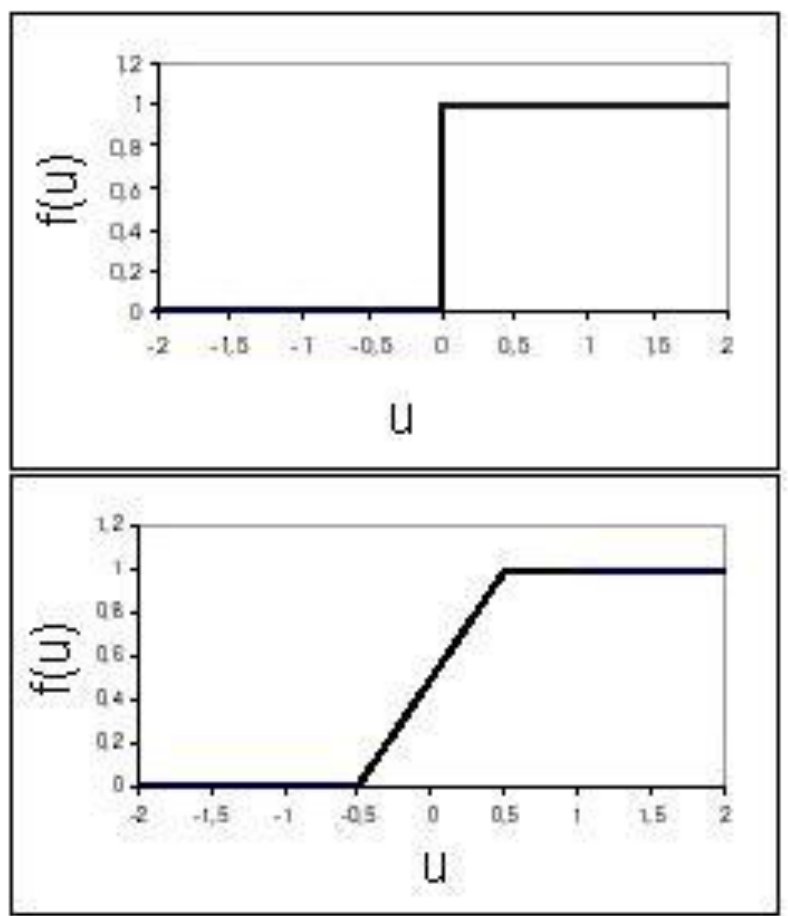

(a)

(b)

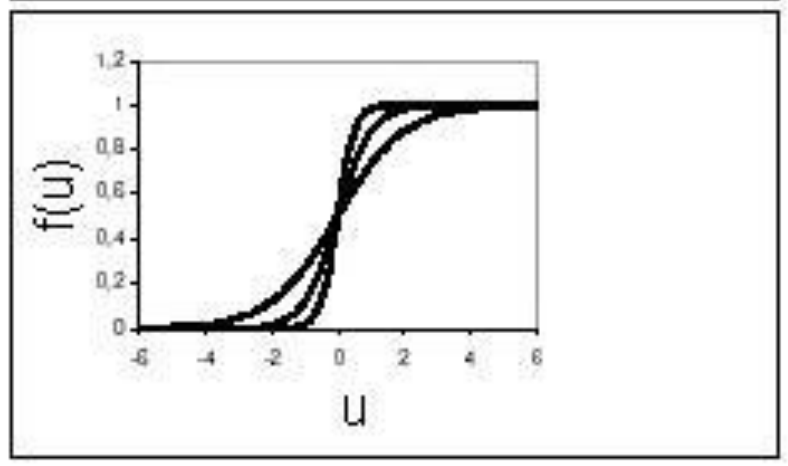

(c)

Figura 9. (a) Função limiar, (b) Função linear por partes (c) Função sigmóide com parâmetro de inclinação a variável

\subsubsection{Arquiteturas de Redes Neurais Artificiais (RNA)}

As formas em que os neurônios da rede neural estão organizados estão intimamente ligadas ao algoritmo de aprendizado utilizado no treinamento da rede. Geralmente, podemos identificar três tipos de arquiteturas de RNA [12]: 
Redes com propagação para frente de uma camada: são compostas por uma camada de entrada e outra de saída, como mostra a Figura 10;

* Redes com propagação para frente de camadas múltiplas: são compostas por uma camada de entrada, uma ou mais camadas ocultas e uma camada de saída, como mostra a Figura 11;

* Redes Recorrentes: contêm realimentação das saídas para as entradas, sendo suas saídas determinadas pelas entradas atuais e pelas saídas anteriores, como pode ser visto na Figura 12.

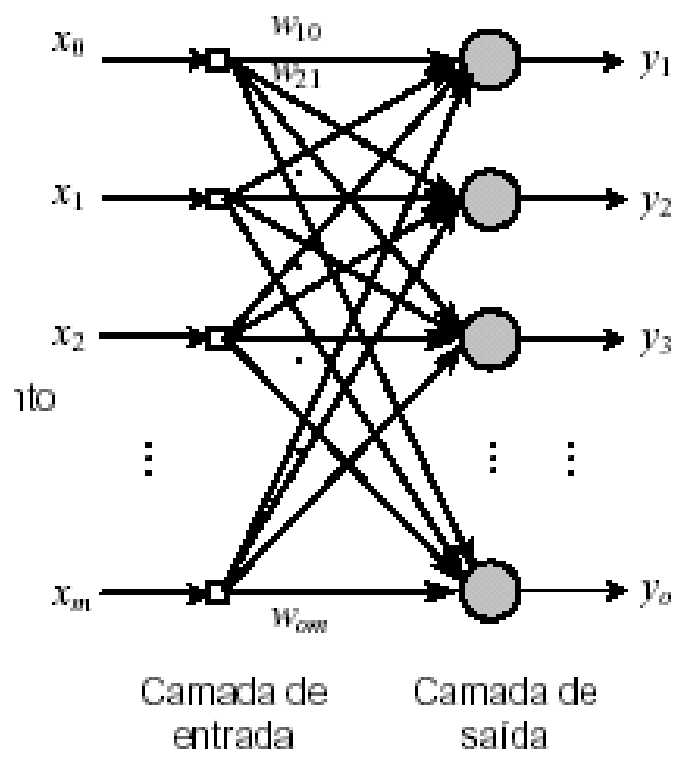

Figura 10. Redes com propagação para frente de uma camada 


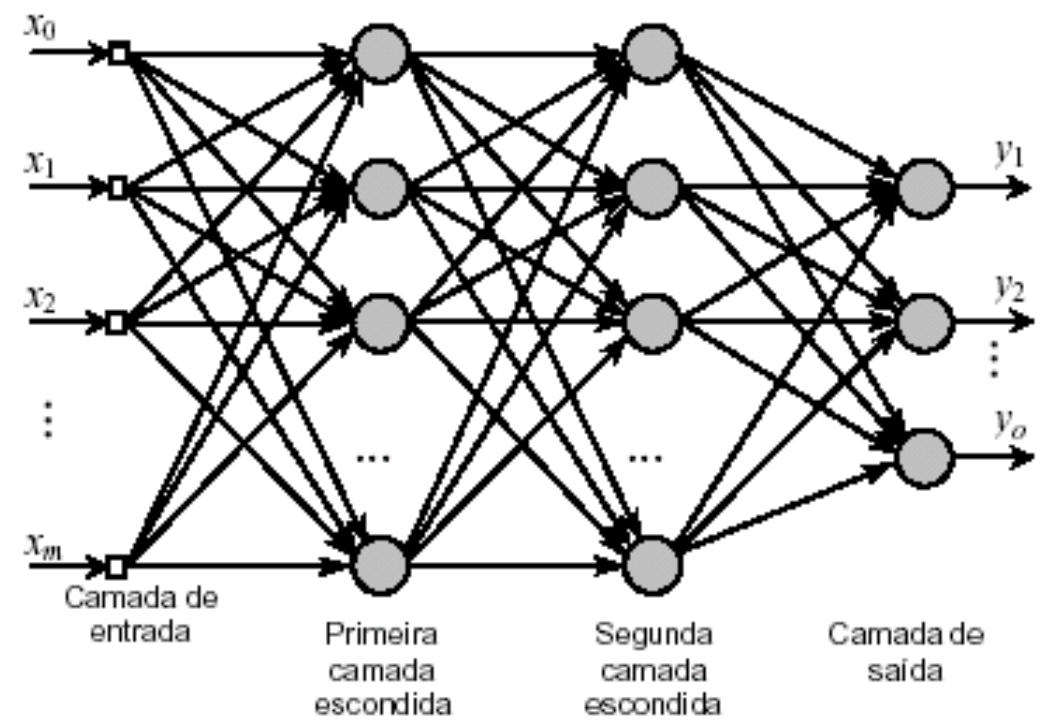

Figura 11. Redes do tipo MLP (Camadas múltiplas com propagação para frente)

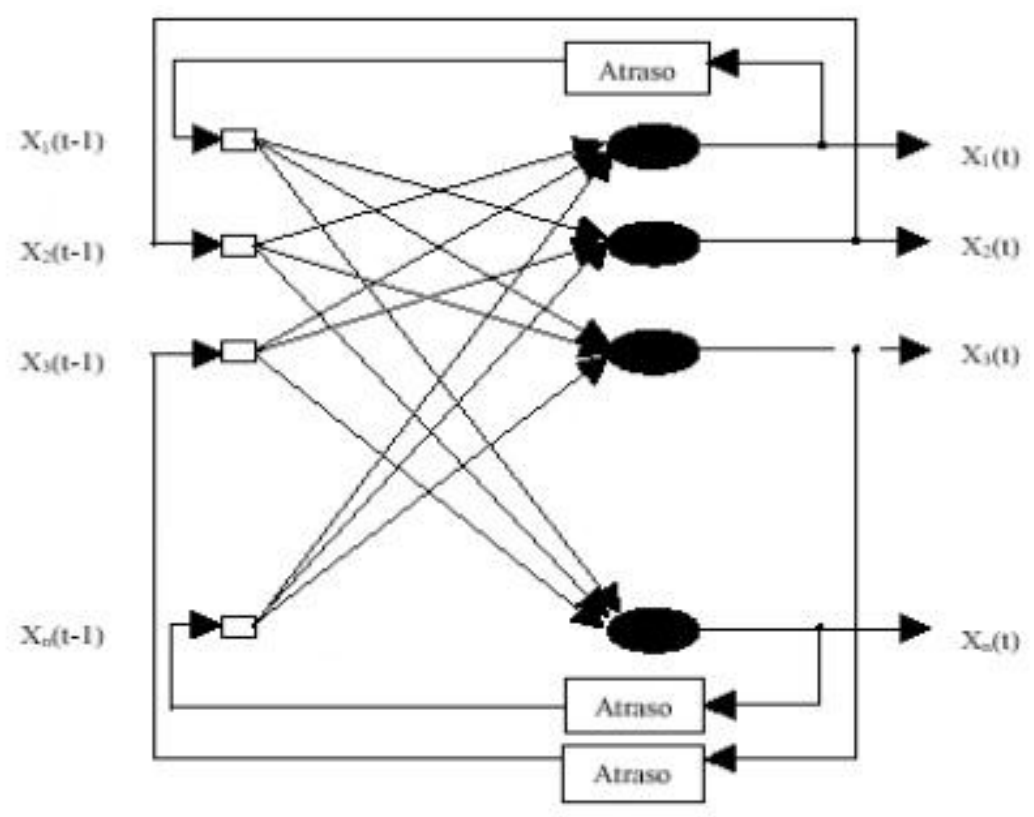

Figura 12. Redes Recorrentes

A arquitetura de rede usada neste trabalho foi a rede com propagação para frente de camadas múltiplas, também conhecida como Multilayer Perceptron (MLP), que será descrita em detalhes no próximo tópico.

\subsubsection{Redes de camadas múltiplas (MLP)}

As redes do tipo MLP são redes multicamadas, formadas por uma camada de entrada, uma ou mais camadas ocultas, e uma camada de saída, como pode ser visto na 
Figura 11. Os neurônios de uma camada recebem os sinais de todos os neurônios das camadas anteriores, e propaga sua saída a todos os neurônios da camada posterior.

A camada de entrada é utilizada para receber os dados de entrada da rede, não efetuando assim qualquer tipo de processamento. O número de neurônios nessa camada corresponde ao tamanho do vetor de entrada.

A camada de saída tem a função de armazenar as respostas obtidas pela rede. $\mathrm{O}$ número de neurônios nessa camada corresponde ao tamanho do vetor de saída.

Entre a camada de entrada e a de saída, podemos ter uma ou mais camadas ocultas. As camadas ocultas proporcionam complexidade e não-linearidade para a rede. Não existe um método que determine o número ideal de camadas ocultas e de neurônios nessa camada, porém a escolha desses parâmetros é muito importante e influencia diretamente o desempenho do sistema, pois o tempo computacional para o cálculo da resposta e para o treinamento da rede aumenta significativamente com o aumento das conexões e de neurônios nas camadas ocultas.

No próximo tópico serão apresentados os principais algoritmos de treinamento.

\subsubsection{Principais Algoritmos de Treinamento}

O principal objetivo do treinamento de uma RNA é fazer com que a aplicação de um conjunto de entradas produza um conjunto de saídas desejadas ou no mínimo um conjunto de saídas consistentes.

O treinamento é realizado pela aplicação sequencial dos vetores de entradas (e em alguns casos também os de saída), enquanto os pesos da rede são ajustados de acordo com um procedimento de treinamento pré-determinado. Durante o treinamento, os pesos da rede gradualmente convergem para determinados valores, de maneira tal que a aplicação dos vetores de entrada produzam as saídas necessárias. Os procedimentos de treinamento das RNA podem ser classificados em duas classes:

\section{* Supervisionado \\ Não supervisionado}

O treinamento supervisionado necessita de um vetor de entrada e um vetor de saída, conhecido como vetor alvo. Esses dois vetores são então utilizados para o treinamento da RNA. O procedimento de treinamento funciona da seguinte maneira: o vetor de entrada é aplicado, a saída de rede é calculada e comparada com o correspondente 
vetor alvo. O erro encontrado é então realimentado através da rede e os pesos são atualizados de acordo com um algoritmo determinado a fim de minimizar este erro. Este processo de treinamento é repetido até que o erro para os vetores de treinamento alcance valores pré-determinados.

O treinamento supervisionado pode ser aplicado em problemas onde existe a necessidade de se obter um mapeamento entre padrões de entrada e saída. A implementação do aprendizado supervisionado pode ser realizada de duas maneiras: offline e online. No treinamento offline, a base de dados de treinamento não muda, sendo assim, após a obtenção da uma solução para o problema a rede permanece fixa. Se existir a necessidade de acrescentar novos dados, será necessário realizar um novo treinamento englobando os dados anteriores.

O treinamento não-supervisionado, por sua vez, não requer vetor alvo para as saídas e, obviamente, não faz comparações para determinar a resposta ideal. O aprendizado não supervisionado pode ser aplicado a problemas cujo propósito seja a descoberta de características relevantes nos dados de entrada. Os modelos mais conhecido de aprendizado não-supervisionado são os Mapas Auto-Organizáveis de Kohonen [2].

Os principais algoritmos de treinamento que serão descritos neste trabalho são: aprendizagem Hebbiana, aprendizagem por competição, aprendizagem por Correção de Erro e aprendizagem pelo Método do Gradiente Descendente.

\subsubsection{Aprendizagem Hebbiana}

O aprendizado Hebbiano é uma das regras de aprendizado mais antiga [13]. Hebb's postulou que a adaptação das sinapses do sistema nervoso é proporcional à atividade dos neurônios pré e pós - sinápticos. A partir desse postulado, Hebb's desenvolveu um algoritmo para a atualização dos pesos, descrito pela equação (15):

$$
\Delta w_{i j}(n)=\eta y_{j}(n) x_{j}(n)
$$

Onde:

$\eta \quad$ : é uma constante que expressa a taxa de aprendizado

$x_{j}(n)$ : entrada da rede

$y_{j}(n)$ : saída da rede 


\subsubsection{Aprendizagem por competição}

O aprendizado por competição baseia-se na apresentação de padrões de entrada para as unidades de saída disputarem entre si para serem ativadas. Na realidade, existe uma competição entre as unidades de saída, para que a vencedora tenha sua saída ativada. A unidade de saída vencedora sofre atualização de seus pesos durante a etapa de treinamento.

As unidades de entrada são conectadas às unidades de saída, que podem por sua vez estar ligadas entre si via conexões laterais inibitórias ou negativas. A unidade de saída que terá uma chance maior de vencer a disputa sobre as outras unidades será aquela com maior ativação inicial. A unidade mais forte torna-se ainda mais forte e o seu efeito inibidor sobre as demais unidades de saída acaba se tornando dominante. Assim, todas as outras unidades ficarão completamente inativas, com exceção da unidade vencedora. $\mathrm{O}$ aprendizado por competição é a base dos mapas auto-organizáveis [2].

\subsubsection{Aprendizagem por Correção de Erro}

O objetivo desse processo de aprendizado é minimizar a diferença entre a saída calculada pela rede e a saída desejada, como mostra a Equação (16):

$$
e(n)=y_{d j}(n)-y_{j}(n)
$$

Onde:

$e_{j}(n)$ : representa o erro da rede

$j:$ neurônio

$y_{d j}(n)$ : saída desejada

$y_{j}(n)$ : saída calculada pela rede.

O erro $e_{j}(n)$ atua como um mecanismo de controle através da aplicação de uma sequência de atualizações aos pesos sinápticos no neurônio j. As atualizações dos pesos sinápticos têm como objetivo aproximar a saída $y_{j}(n)$ da saída desejada $y_{d j}(n)$, através da minimização da energia do erro, $\varepsilon(n)$, definida em função do erro $e_{j}(n)$, como pode ser visto na equação (17): 


$$
\varepsilon(n)=\frac{1}{2} e_{j}^{2}(n)
$$

Onde :

$\varepsilon(n)$ : energia do erro

A equação (18) mostra como é feita a atualização dos pesos:

$$
w_{i j}(n+1)=w_{i j}(n)+\Delta w_{i j}(n)
$$

Onde:

$w_{i j}(n+1):$ peso atualizado

$w_{i j}(n)$ : peso antigo

O ajuste aos pesos sinápticos no neurônio $k$ continua, até que o sistema atinja a estabilidade. Logo após, o processo de aprendizado é interrompido.

\subsubsection{Regra Delta ou Método do Gradiente Descendente}

O método do Gradiente Descendente tem como propósito principal minimizar uma função de erro, que é definida pela soma dos erros quadráticos, como mostra a equação (19):

$$
E=\frac{1}{2} \sum_{n=1}^{m}\left(y_{d j}(n)-y_{j}(n)\right)^{2}
$$

Onde:

$E$ : representa o erro

m: número de neurônios na camada de saída

$y_{d j}:$ saída desejada

$y_{j}$ : saída calculada pela rede 
No método do gradiente descendente verifica-se que com o decréscimo do erro, o peso tende a aumentar o que fortalece a ligação entre os neurônios. Quando ocorre o aumento do erro, o peso tende a diminuir, conforme a equação (20).

$$
w_{i j}(n+1)=w_{i j}(n)-\eta \frac{\partial E}{\partial w_{i j}}
$$

Onde:

$$
\begin{aligned}
& w_{i j}(n+1): \text { peso atualizado } \\
& w_{i j}(n): \text { peso antigo } \\
& \eta: \text { taxa de aprendizado } \\
& \frac{\partial E}{\partial w_{i j}}: \text { gradiente }
\end{aligned}
$$

O algoritmo de retropropagação, que foi utilizado no treinamento das RNA deste trabalho, utiliza a regra delta generalizada. Este algoritmo será descrito em detalhes, no próximo tópico.

\subsubsection{Algoritmo de Retropropagação}

O algoritmo de retropropagação é utilizado no treinamento das RNA do tipo MLP, descrita no item 4.3.4.1.

O algoritmo de retropropagação é um algoritmo supervisionado que utiliza pares (entrada, saída desejada) para ajustar os pesos sinápticos da RNA através de um mecanismo de correção. O treinamento ocorre em duas fases distintas conhecidas como "forward" e "backward". Na fase forward, é definida a saída da rede para um dado padrão de entrada, e na fase backward, a diferença entre a saída desejada e a saída atual é utilizada pela rede para atualizar os pesos de suas conexões.

A implantação computacional do algoritmo de retropropagação apresenta os seguintes passos [2]:

Passo 1: Inicialização de todos os pesos e parâmetros.

Passo 2: Fase forward, consiste em: 
Dadas as entradas, calcular as saídas para todas as camadas da rede;

Calcular o erro de saída da rede.

Passo 3: Fase backward, consiste em:

Efetuar o cálculo das atualizações dos pesos entre as camadas da rede, iniciando a partir da última camada, até chegar à camada de entrada;

O algoritmo de retropropagação consiste na utilização dos pesos, considerando a propagação do erro da saída da rede para a sua entrada. Este algoritmo é também conhecido como regra delta generalizada.

Embora o erro total E seja definido pela soma dos erros dos neurônios de saída para todos os padrões, será considerado, sem perda de generalidade, que a minimização do erro para cada padrão individualmente levará à minimização do erro total para todos os padrões. Portanto, o erro passa a ser definido conforme a equação (19), descrita anteriormente.

Como na regra delta a variação dos pesos é definida de acordo com o gradiente descendente, partindo-se da equação (21) é calculada matematicamente a equação (22), sendo $\Delta w=w(n+1)-w(n)$ :

$$
\Delta w_{i j}=-\eta \frac{\partial E}{\partial w_{i j}}
$$

Logo:

$$
\begin{aligned}
& \Delta w_{i j}=-\eta \frac{\partial E}{\partial w_{i j}}=-\eta \frac{\partial E}{\partial y_{j}} \frac{\partial y_{j}}{\partial w_{i j}} \\
& y_{j}=\left(\sum_{m=1}^{m} x_{j} w_{i j}\right) \\
& \Delta w_{i j}=-\eta\left[2 \times \frac{1}{2} \times\left(y_{d j}-y_{j}\right) \times(-1)\right] x_{j}
\end{aligned}
$$




$$
\Delta w_{i j}=-\eta\left[-\left(y_{d j}-y_{j}\right)\right] x_{j}
$$

$$
\Delta w_{i j}=x_{j} \eta\left(y_{d j}-y_{j}\right)
$$

Onde:

$w$ : indica o valor dos pesos

$y_{d j}:$ saída desejada

$y_{j}$ : saída calculada pela rede

$\eta$ : taxa de aprendizado

$x_{j}$ : entrada da rede 


\section{DESENVOLVIMENTO DO TRABALHO}

A implementação do Sistema de Monitoração e Detecção de Falhas consistiu em realizar o pré-processamento das informações através do algoritmo GMDH e posteriormente em treinar as RNA para estimar a variável monitorada. A Monitoração é feita comparando-se o valor lido da variável com o valor estimado pela rede Neural; já a Detecção de Falhas consistiu em testar as RNA com uma base de dados contendo informações de sensores falhos. Após a realização desses testes, se o resíduo obtido na Detecção for maior do que o da Monitoração considera-se que existe falha no sensor. A Figura 13 apresenta resumidamente as etapas de implantação do presente trabalho.

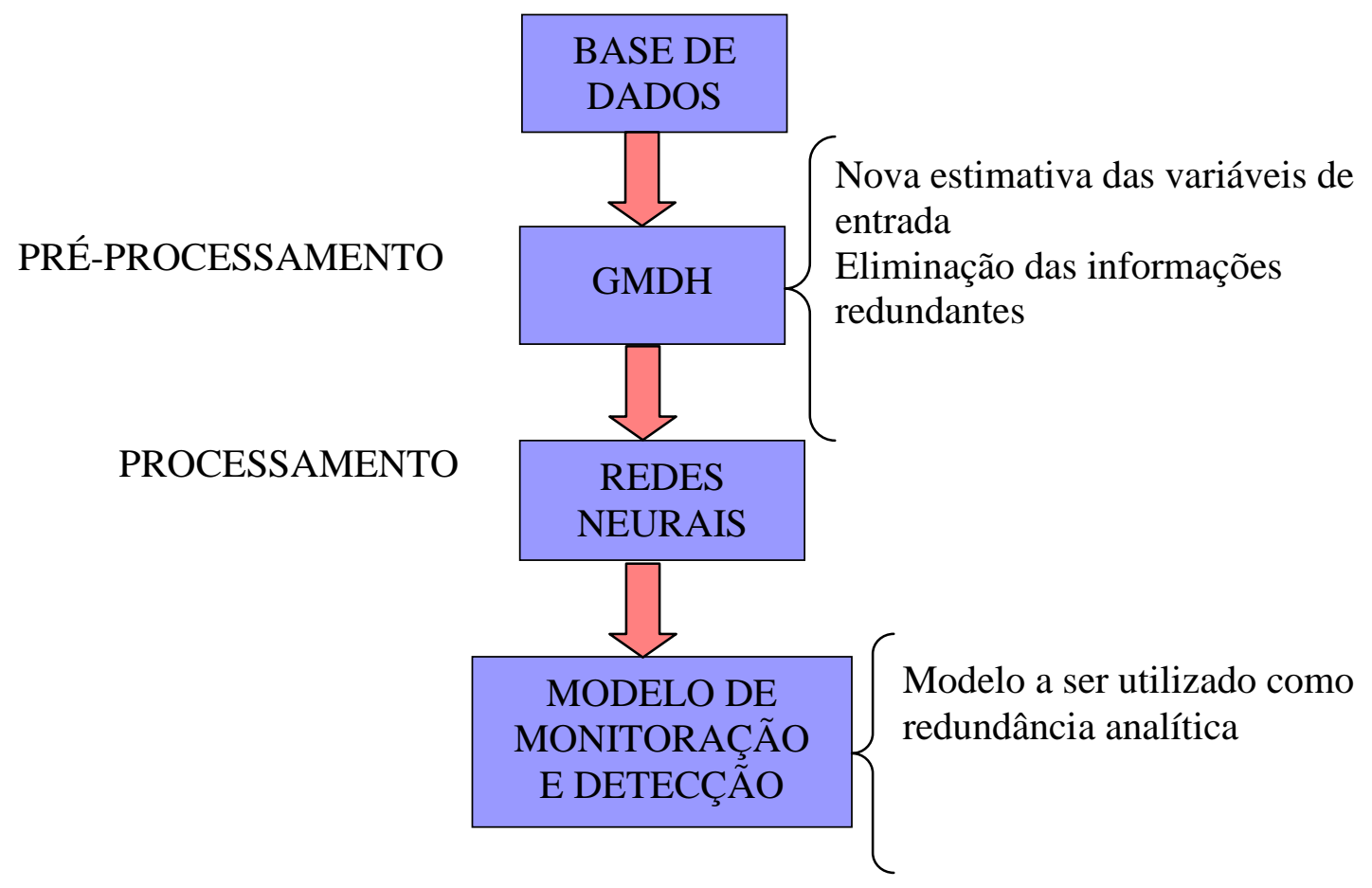

Figura 13. Resumo - implementação da metodologia desenvolvida 
Para realizar o pré-processamento das variáveis de entrada, primeiramente utilizou-se a matriz_z obtida através do algoritmo GMDH. Essa escolha ocorreu em decorrência dessa matriz apresentar uma melhor estimativa das variáveis de entrada (vide seção 4.2). Após a obtenção da matriz_z foram treinadas RNA para a Monitoração e Detecção de Falhas em sensores através dos modelos desenvolvidos. Esses modelos serão explicados nos próximos tópicos.

Tendo em vista os resultados obtidos através do pré-processamento usando a matriz_z, decidiu-se investigar as variáveis de maior relevância para o algoritmo GMDH. Para isso, foram computados $o$ s termos que tiveram uma predominância maior na equação polinomial, e as variáveis correspondentes a estes termos foram utilizadas como variáveis de entrada para o treinamento de novas RNA.

Os resultados obtidos serão apresentados no capítulo 6.

\subsection{Base de dados do Sistema de Monitoração}

Neste trabalho foram utilizados diferentes conjuntos de variáveis como entrada do Sistema de Monitoração. Para cada conjunto de variáveis de entrada foi desenvolvido um Sistema de Monitoração chamados de Modelo 1, Modelo 2, e assim por diante. Ao todo foram feitos 5 Modelos que serão descritos a seguir.

\subsubsection{Modelo 1 - teórico}

Para a implementação do sistema de Monitoração e Detecção de Falhas, primeiramente foram realizados testes usando dados gerados pelo modelo teórico do reator [23].

O modelo teórico foi utilizado para realizar cálculos com a precisão desejada e para comparar os erros da metodologia (vide seção 3.3). Esse estudo inicial foi de extrema importância, pois o modelo teórico não sofre influências de ruídos, e o único erro associado ao modelo é o de arredondamento do computador.

Através deste modelo, foram gerados dados variando-se a Potência (N2) de 0 a $100 \%$, em intervalos de $5 \%$ em 5\%, sendo que para cada condição de potência gerada, foram criados 20 exemplos, totalizando 420 exemplos. Foram adicionados ruídos de $0,4 \%$ na variável T3 e 1\% na variável F1M3, por serem flutuações típicas observadas durante a operação do reator IEA-R1 [27]. 
As variáveis abrangidas pelo modelo 1 são: T1, T2, T3, T4, T6, T7, T8, T9, F1M3, F2M3 e N2.

\subsubsection{Modelo 2 - dados de operação do reator}

Após a realização de testes usando dados do Modelo 1, foram propostos os modelos: 2, 3, 4 e 5 contendo dados referentes a uma semana típica de operação do reator. Para a realização deste trabalho, foram utilizados dados referente à primeira semana de fevereiro/2009 de operação do reator.

O modelo 2 é composto por nove variáveis e foi elaborado para realizar um estudo comparativo aos resultados obtidos através do modelo 1. Neste modelo, as variáveis T1 e T2 não foram utilizadas, por realizarem uma medição muito próxima à do sensor de temperatura T3. Além disso, neste modelo, decidiu-se incluir a variável taxa de dose, pois a obtenção do seu valor é complexa, visto que se devem considerar todos os caminhos percorridos desde sua emissão no núcleo do reator, passando pelas estruturas dos elementos combustíveis, piscina, saguão do reator, etc, até atingir os detectores de radiação. No caso das variáveis de processo, as equações de transferência de calor são conhecidas e relativamente simples de serem obtidas.

As variáveis abrangidas pelo modelo 2 são: N2, F1M3, F2M3, R1M3, T3, T4, T7, T8 e T9.

\subsubsection{Modelo 3 - dados de operação do reator}

O modelo 3 é composto por treze variáveis. Neste modelo, foram acrescentadas informações das variáveis nucleares (Z1, Z2 e Z3).

As variáveis abrangidas pelo modelo 3 são: Z1, Z2, Z3, N2, F1M3, F2M3, R1M3, F2M3, T3, T4, T7, T8 e T9.

\subsubsection{Modelo 4 - dados de operação do reator}

O modelo 4 é composto por onze variáveis. Neste modelo, decidiu-se estudar a influência da variável vazão no modelo de Monitoração, retirando-se essa variável do modelo.

As variáveis abrangidas pelo modelo 4 são: Z1, Z2, Z3, N2, R1M3, R2M3, T3, T4, T7, T8 е T9. 


\subsubsection{Modelo 5 - dados de operação do reator}

Finalmente, decidiu-se compor um modelo que contivesse todas as variáveis do SAD. Porém, analisando-se a tabela 1, observa-se que nem todas as variáveis são efetivamente importantes para um Sistema de Monitoração e Diagnóstico e por isso o modelo 5 é composto por trinta e oito variáveis. Das 58 variáveis do SAD, foram consideradas apenas as variáveis mais importantes do reator de pesquisas do Ipen IEA-R1, sendo desprezadas das seguintes variáveis:

* F3M3: reator não estava utilizando o trocador B durante a operação;

* F23, DP e L1: fornecem, respectivamente, informações da vazão de água de emergência; delta $\mathrm{P}$ do núcleo e nível da piscina;

* T5: fornece a diferença de temperatura entre as variáveis T3 e T4, que já estão abrangidas pelo modelo 5;

* T10, T11, T12: são sensores que medem temperatura quando o reator está utilizando o trocador $\mathrm{B}$, tendo em vista que nesta semana de operação foi utilizado $\mathrm{o}$ trocador $\mathrm{A}$, essas variáveis foram desconsideradas;

* T13, T14, T15, T16, T17, T18, T19, T20, T21, T22, T23 е T24: fornecem valores de temperatura irrelevantes para o desenvolvimento do sistema proposto.

As variáveis abrangidas pelo modelo 5 são: Z1, Z2, Z3, Z4, N1, N2, N3, N4, N5, N6, N7, N8, C1, C2, F1M3, F2M3, R1M3, R2M3, R3M3, R4M3, R5M3, R6M3, R7M3, R8M3, R9M3, R10M3, R11M3, R12M3, R13M3, R14M3, T1, T2, T3, T4, T6, T7, T8 e T9.

\subsection{Pré-processamento}

\subsubsection{Nova estimativa das variáveis de entrada (GMDH + RNA)}

Para realizar o pré-processamento das variáveis de entrada, optou-se primeiramente por utilizar a matriz_z (vide seção 4.2) obtida através do algoritmo GMDH. Essa escolha ocorreu em virtude dessa matriz ser uma nova estimativa das variáveis de entrada, possibilitando a obtenção de resultados para iniciar a implementação do presente trabalho. 
Após a etapa de pré-processamento, a matriz_z obtida através do GMDH, foi utilizada como uma nova e melhor estimativa das variáveis de entrada no treinamento das RNA, como mostrado na Figura 14.

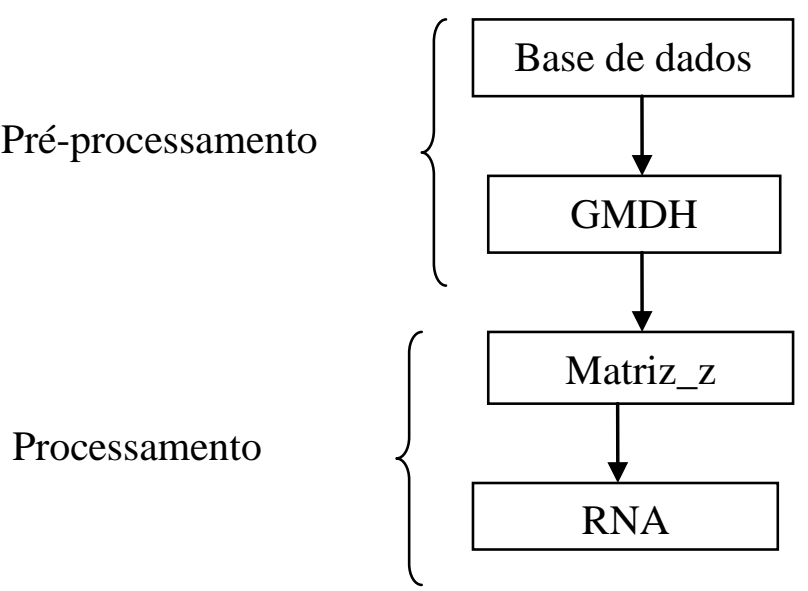

Figura 14. Pré-processamento através da matriz_z

\subsubsection{Variáveis mais relevantes (RNA seleção)}

Após a análise dos resultados da etapa anterior, decidiu-se investigar efetivamente quais são as variáveis de entrada descartadas pelo GMDH. Inicialmente foi feito um estudo da propagação das variáveis de entrada nas diferentes camadas do algoritmo GMDH (vide seção 4.2), onde foi observado o maior número de ocorrência em que cada um dos termos da equação polinomial apareceu (vide equação 5), levando-se em consideração a camada que obteve o menor RMIN, calculado através da equação (8). Esses termos que tiveram uma maior predominância na equação polinomial foram utilizados no treinamento das RNA como variáveis de entrada. A Figura 15 apresenta a etapa de préprocessamento realizada através do estudo das variáveis mais relevantes. 


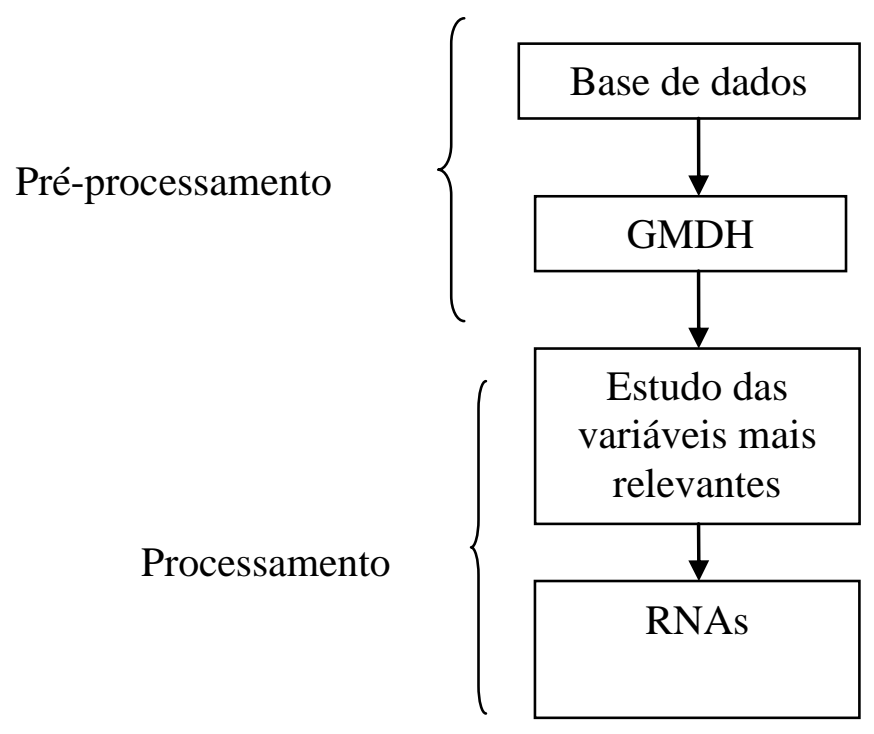

Figura 15. Pré-processamento - estudo das variáveis mais relevantes

A determinação das variáveis de entrada que tiveram maior predominância no modelo GMHD foi feita da maneira descrita a seguir. Sejam os seguintes conjuntos de $n$ variáveis de entrada: x1, x2, x3 e x4 (matriz X), e o correspondente conjunto de variáveis de saída Y.

$$
X=\left[\begin{array}{llll}
x_{11} & x_{12} & x_{13} & x_{14} \\
x_{21} & x_{22} & x_{23} & x_{24} \\
\cdots & \cdots & \cdots & \cdots \\
x_{n 1} & x_{n 2} & x_{n 3} & x_{n 4}
\end{array}\right] \quad Y=\left[\begin{array}{c}
y_{1} \\
y_{2} \\
\cdots \\
y_{n}
\end{array}\right]
$$

\section{Geraç̃̃o 1:}

Conforme explicado na descrição do algoritmo GMDH, devem-se fazer combinações de 2 a 2 variáveis e utilizar a equação (3) para estudar as variáveis mais relevantes para o algoritmo GMDH. Como a matriz x é composta por 4 variáveis de entrada, o número de combinações possíveis é dado por:

$$
C=\frac{4(4-1)}{2} \Rightarrow C=6
$$

E, portanto o número de colunas da matriz z será igual a 6. Os coeficientes da equação (3) são calculados da forma a seguir: 


$$
\begin{aligned}
& y_{1}=a_{12}+b_{12} x_{1}+c_{12} x_{2}+d_{12} x_{1}^{2}+e_{12} x_{2}^{2}+f_{12} x_{1} x_{2} \\
& y_{2}=a_{13}+b_{13} x_{1}+c_{13} x_{3}+d_{13} x_{1}^{2}+e_{13} x_{3}^{2}+f_{13} x_{1} x_{3} \\
& y_{3}=a_{14}+b_{14} x_{1}+c_{14} x_{4}+d_{14} x_{1}^{2}+e_{14} x_{4}^{2}+f_{14} x_{1} x_{4} \\
& y_{4}=a_{23}+b_{23} x_{2}+c_{23} x_{3}+d_{23} x_{2}^{2}+e_{23} x_{3}^{2}+f_{23} x_{2} x_{3} \\
& y_{5}=a_{24}+b_{24} x_{2}+c_{24} x_{4}+d_{24} x_{2}^{2}+e_{24} x_{4}^{2}+f_{24} x_{2} x_{4} \\
& y_{6}=a_{34}+b_{34} x_{3}+c_{34} x_{4}+d_{34} x_{3}^{2}+e_{34} x_{4}^{2}+f_{34} x_{3} x_{4}
\end{aligned}
$$

Substituem-se agora os valores dos coeficientes calculados nas respectivas equações polinomiais, para determinar os termos da matriz z, lembrando que os subscritos p e q correspondem às possíveis combinações das variáveis de entrada:

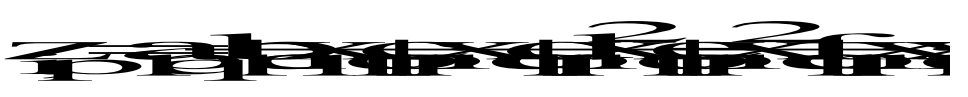

Logo, a matriz z é obtida como segue:

$$
Z=\left[\begin{array}{llllll}
z_{11} & z_{12} & z_{13} & z_{14} & z_{15} & z_{16} \\
z_{21} & z_{22} & z_{23} & z_{24} & z_{25} & z_{26} \\
\cdots & \cdots & \cdots & \cdots & \cdots & \cdots \\
z_{n 1} & z_{n 2} & z_{n 3} & z_{n 4} & z_{n 5} & z_{n 6}
\end{array}\right]
$$

Após a obtenção da matriz z, calcula-se o desvio médio quadrático rj, obtido através da equação (8) para cada coluna dessa matriz. As colunas de Z são ordenadas em ordem crescente de $r_{j}$. Para as explicações deste exemplo, vamos considerar que as colunas já estão ordenadas. Tendo em vista que a cada geração do algoritmo GMDH o número de combinações possíveis das variáveis pode aumentar de uma forma descontrolada, estipulase um critério para continuar o algoritmo na formação da matriz_z da próxima geração. Assim, consideraremos as 4 primeiras colunas dessa matriz para prosseguir na próxima geração.

\section{Geração 2:}

Esse mesmo procedimento será repetido para a geração 2, porém as colunas da matriz representam, respectivamente, as variáveis: $\mathrm{x}_{1} \mathrm{x}_{2}, \mathrm{x}_{1} \mathrm{x}_{3}, \mathrm{x}_{1} \mathrm{x}_{4}, \mathrm{x}_{2} \mathrm{x}_{3}$. Tendo em vista que na geração 1 já foi feita a dedução matemática da equação polinomial, será adotada 
uma representação de forma resumida desta equação, onde $f=\left(x_{a}^{n} x_{b}^{n} x_{c}^{n} \cdots x_{m}^{n}\right)$ representam os polinômios gerados para a obtenção da matriz Z.

$$
\begin{aligned}
& y_{1}=f\left(x_{1} x_{2} x_{1} x_{3}\right) \Rightarrow y_{1}=f\left(x_{1}^{2} x_{2} x_{3}\right) \\
& y_{2}=f\left(x_{1} x_{2} x_{1} x_{4}\right) \Rightarrow y_{2}=f\left(x_{1}^{2} x_{2} x_{4}\right) \\
& y_{3}=f\left(x_{1} x_{2} x_{2} x_{3}\right) \Rightarrow y_{3}=f\left(x_{1} x_{2}^{2} x_{3}\right) \\
& y_{4}=f\left(x_{1} x_{3} x_{1} x_{4}\right) \Rightarrow y_{4}=f\left(x_{1}^{2} x_{3} x_{4}\right) \\
& y_{5}=f\left(x_{1} x_{3} x_{2} x_{3}\right) \Rightarrow y_{5}=f\left(x_{1} x_{2} x_{3}^{2}\right) \\
& y_{6}=f\left(x_{1} x_{4} x_{2} x_{3}\right) \Rightarrow y_{6}=f\left(x_{1} x_{2} x_{3} x_{4}\right)
\end{aligned}
$$

Nesta camada, a matriz Z é composta por 6 colunas (vide equação 35), que representa os polinômios previamente calculados. Calcula-se rj e, em seguida, é feito o ordenamento das colunas da matriz $\mathrm{Z}$ e novamente as duas últimas colunas são desprezadas.

\section{Geracão 3:}

Esse mesmo procedimento será repetido para a geração 3, porém as colunas da matriz representam, respectivamente, as variáveis: $\mathrm{x}_{1} \mathrm{x}_{2} \mathrm{x}_{1} \mathrm{x}_{3}, \mathrm{x}_{1} \mathrm{x}_{2} \mathrm{x}_{1} \mathrm{x}_{4}, \mathrm{x}_{1} \mathrm{x}_{2} \mathrm{x}_{2} \mathrm{x}_{3}, \mathrm{x}_{1} \mathrm{x}_{3} \mathrm{x}_{1} \mathrm{x}_{4}$. Desta maneira, teremos os seguintes polinômios:

$$
\begin{aligned}
& y_{1}=f\left(x_{1} x_{2} x_{1} x_{3} x_{1} x_{2} x_{1} x_{4}\right) \Rightarrow y_{1}=f\left(x_{1}^{4} x_{2}^{2} x_{3} x_{4}\right) \\
& y_{2}=f\left(x_{1} x_{2} x_{1} x_{3} x_{1} x_{2} x_{2} x_{3}\right) \Rightarrow y_{2}=f\left(x_{1}^{3} x_{2}^{3} x_{3}^{2}\right) \\
& y_{3}=f\left(x_{1} x_{2} x_{1} x_{3} x_{1} x_{3} x_{1} x_{4}\right) \Rightarrow y_{3}=f\left(x_{1}^{4} x_{2} x_{3}^{2} x_{4}\right) \\
& y_{4}=f\left(x_{1} x_{2} x_{1} x_{4} x_{1} x_{2} x_{2} x_{3}\right) \Rightarrow y_{4}=f\left(x_{1}^{3} x_{2}^{3} x_{3} x_{4}\right) \\
& y_{5}=f\left(x_{1} x_{2} x_{1} x_{4} x_{1} x_{3} x_{1} x_{4}\right) \Rightarrow y_{5}=f\left(x_{1}^{4} x_{2} x_{3} x_{4}^{2}\right) \\
& y_{6}=f\left(x_{1} x_{2} x_{2} x_{3} x_{1} x_{3} x_{1} x_{4}\right) \Rightarrow y_{6}=f\left(x_{1}^{3} x_{2}^{2} x_{3}^{2} x_{4}\right)
\end{aligned}
$$

\section{Geracão 4:}

Esse mesmo procedimento será repetido para a geração 4, porém as colunas da matriz representam, respectivamente, as variáveis: $\mathrm{x}_{1} \mathrm{X}_{2} \mathrm{X}_{1} \mathrm{X}_{3} \mathrm{X}_{1} \mathrm{X}_{2} \mathrm{X}_{1} \mathrm{X}_{4}, \mathrm{x}_{1} \mathrm{X}_{2} \mathrm{X}_{1} \mathrm{X}_{3} \mathrm{X}_{1} \mathrm{X}_{2} \mathrm{X}_{2} \mathrm{X}_{3}$, $\mathrm{X}_{1} \mathrm{X}_{2} \mathrm{X}_{1} \mathrm{X}_{3} \mathrm{X}_{1} \mathrm{X}_{3} \mathrm{X}_{1} \mathrm{X}_{4}, \mathrm{X}_{1} \mathrm{X}_{2} \mathrm{X}_{1} \mathrm{X}_{4} \mathrm{X}_{1} \mathrm{X}_{2} \mathrm{X}_{2} \mathrm{X}_{3}$. Desta maneira, teremos os seguintes polinômios: 


$$
\begin{aligned}
& y_{1}=f\left(x_{1} x_{2} x_{1} x_{3} x_{1} x_{2} x_{1} x_{4} x_{1} x_{2} x_{1} x_{3} x_{1} x_{2} x_{2} x_{3}\right) \Rightarrow y_{1}=f\left(x_{1}^{7} x_{2}^{5} x_{3}^{3} x_{4}\right) \\
& y_{2}=f\left(x_{1} x_{2} x_{1} x_{3} x_{1} x_{2} x_{1} x_{4} x_{1} x_{2} x_{1} x_{3} x_{1} x_{3} x_{1} x_{4}\right) \Rightarrow y_{2}=f\left(x_{1}^{8} x_{2}^{3} x_{3}^{3} x_{4}^{2}\right) \\
& y_{3}=f\left(x_{1} x_{2} x_{1} x_{3} x_{1} x_{2} x_{1} x_{4} x_{1} x_{2} x_{1} x_{4} x_{1} x_{2} x_{2} x_{3}\right) \Rightarrow y_{3}=f\left(x_{1}^{7} x_{2}^{5} x_{3}^{2} x_{4}^{2}\right) \\
& y_{4}=f\left(x_{1} x_{2} x_{1} x_{3} x_{1} x_{2} x_{2} x_{3} x_{1} x_{2} x_{1} x_{3} x_{1} x_{3} x_{1} x_{4}\right) \Rightarrow y_{4}=f\left(x_{1}^{7} x_{2}^{4} x_{3}^{4}\right) \\
& y_{5}=f\left(x_{1} x_{2} x_{1} x_{3} x_{1} x_{2} x_{2} x_{3} x_{1} x_{2} x_{1} x_{4} x_{1} x_{2} x_{2} x_{3}\right) \Rightarrow y_{5}=f\left(x_{1}^{6} x_{2}^{6} x_{3}^{2} x_{4}\right) \\
& y_{6}=f\left(x_{1} x_{2} x_{1} x_{3} x_{1} x_{3} x_{4} x_{1} x_{2} x_{1} x_{4} x_{2} x_{2} x_{3}\right) \Rightarrow y_{6}=f\left(x_{1}^{7} x_{2}^{4} x_{3}^{3} x_{4}^{2}\right)
\end{aligned}
$$

Assumindo-se que o melhor resultado obtido foi na geração 4, avalia-se as variáveis independentes que tiveram uma relevância maior. Essa análise é feita contandose o número de vezes que cada uma dessas variáveis apareceu na equação polinomial, sendo o número de vezes equivalente ao expoente das variáveis. A ordem de cada uma delas (considerando o maior expoente) é respectivamente: $\mathrm{x}_{1}{ }^{8}, \mathrm{x}_{2}{ }^{6}, \mathrm{x}_{3}{ }^{3}$ e $\mathrm{x}_{4}{ }^{2}$. Desta maneira, as variáveis que tiveram um peso maior foram x1 e x2, pois tiveram uma predominância maior do que x3 e x4 no algoritmo GMDH, portanto, nesse exemplo, essas variáveis serão utilizadas no treinamento das RNA para o desenvolvimento do Sistema de Monitoração e Diagnóstico.

\subsection{Processamento}

\subsubsection{Arquitetura das RNA}

Foram desenvolvidas redes do tipo MLP com três (3) camadas, usando a ferramenta de Redes Neurais do Matlab. Esta arquitetura foi escolhida por ter apresentado resultados melhores do que os obtidos com redes do tipo Elman. As redes foram treinadas pelo método de retropropagação do erro, baseado no algoritmo de Levenberg-Marquardt [11]. Para efeitos de comparação, foram realizados os seguintes testes: GMDH + RNA, RNA e GMDH separamente.

As bases de dados utilizadas neste trabalho foram normalizadas no intervalo de 0 a 1, através da equação (54):

$$
x(n)=\frac{x-\text { MinVal }}{\text { MaxVal }- \text { MinVal }}
$$


Onde:

$\mathrm{x}(\mathrm{n})$ : valor normalizado das entradas $[0,1]$

$\mathrm{x}$ : entradas

MinVal: Valor mínimo da base de dados $\mathrm{x}$

MaxVal: Valor máximo da base de dados $\mathrm{x}$

Foram estabelecidos dois parâmetros para interromper o treinamento das Redes Neurais. O primeiro parâmetro foi o MSE (Erro Médio Quadrático), cujo valor foi de $10^{-4}$; e o segundo parâmetro foi o número máximo de épocas, cujo valor foi 1000. Inicialmente, o MSE era de $10^{-2}$, porém todas as redes atendiam a este critério e no intuito de reduzir ainda mais o valor do MSE, decidiu-se adotar o valor citado acima.

No treinamento das redes, foi utilizado o método de "Parada Antecipada" (Early Stopping). Este método sugere uma divisão da base de dados em três subconjuntos: treinamento, validação e teste, sendo adotada a seguinte proporção para cada um desses subconjuntos: $60 \%$ treinamento, $20 \%$ validação e $20 \%$ teste. O conjunto de treinamento é usado para calcular o gradiente e atualizar os pesos e bias da rede; o de validação é usado para monitorar o erro durante o processo de treinamento; e o de teste é usado para comparar diferentes modelos.

Como parâmetro para escolha do melhor modelo de monitoração foi adotado o cálculo do resíduo através da equação (55). O modelo que apresentasse o menor resíduo seria adotado para o desenvolvimento do Sistema de Monitoração e Detecção de Falhas.

$$
\text { resíduo }=\left(\left|\frac{y-y_{d}}{y}\right|\right) \times 100
$$

Onde:

y: valor medido

$\mathrm{y}_{\mathrm{d}}$ : valor estimado

Através deste estudo pode-se concluir o tipo de arquitetura, o número aproximado de neurônios na camada escondida e o algoritmo de treinamento, usados neste trabalho. Os resultados obtidos serão comentados no capítulo 6. 


\section{MONITORAÇÃO}

Conforme explicado anteriormente, a monitoração consiste na comparação entre o valor lido da variável e o valor estimado pelo Sistema de Monitoração e Diagnóstico. Essa comparação é feita através do cálculo do resíduo (vide equação 55), que serve também como parâmetro de comparação entre os diferentes conjuntos de variáveis de entrada das redes neurais (diferentes Modelos desenvolvidos).

Para os modelos 1 e 2, utilizou-se apenas o pré-processamento GMDH+RNA e para os demais modelos foram utilizadas as duas formas de pré-processamentos GMDH+RNA e RNA seleção. Em todos os resultados mostrados a seguir têm-se também os resultados de monitoração utilizando apenas as redes neurais, sem a etapa de préprocessamento, com a finalidade de comparar os resultados obtidos.

\subsection{Nova estimativa das variáveis de entrada (GMDH + RNA)}

\subsubsection{Modelo 1 - dados teóricos}

Como descrito no capítulo anterior, o conjunto de variáveis do modelo 1 são: T1, T2, T3, T4, T6, T7, T8, T9, F1M3, F2M3 e N2.

\section{- Potência (N2)}

Para a monitoração da Potência (N2), foram treinadas 10 RNA variando-se o número de neurônios na camada escondida de 1 a 10, com o propósito de identificar o número adequado de neurônios na camada escondida. Este procedimento foi utilizado em todos os modelos e na monitoração de todas as variáveis que serão apresentadas ao longo deste trabalho. Na camada de entrada foi utilizada uma melhor estimativa das variáveis de entrada (matriz_z) obtida através do algoritmo GMDH.

Como critério de escolha do melhor modelo de monitoração, foi adotado o cálculo do menor resíduo obtido, descrito através da equação (55). Nas Figuras 16 a 24 são apresentados os resultados da monitoração das variáveis do Modelo 1 utilizando o uso combinado de GMDH + RNA, e apenas RNA. 
Como pode ser observado na Figura 16, a combinação dos métodos GMDH e RNA apresentou os menores valores residuais.

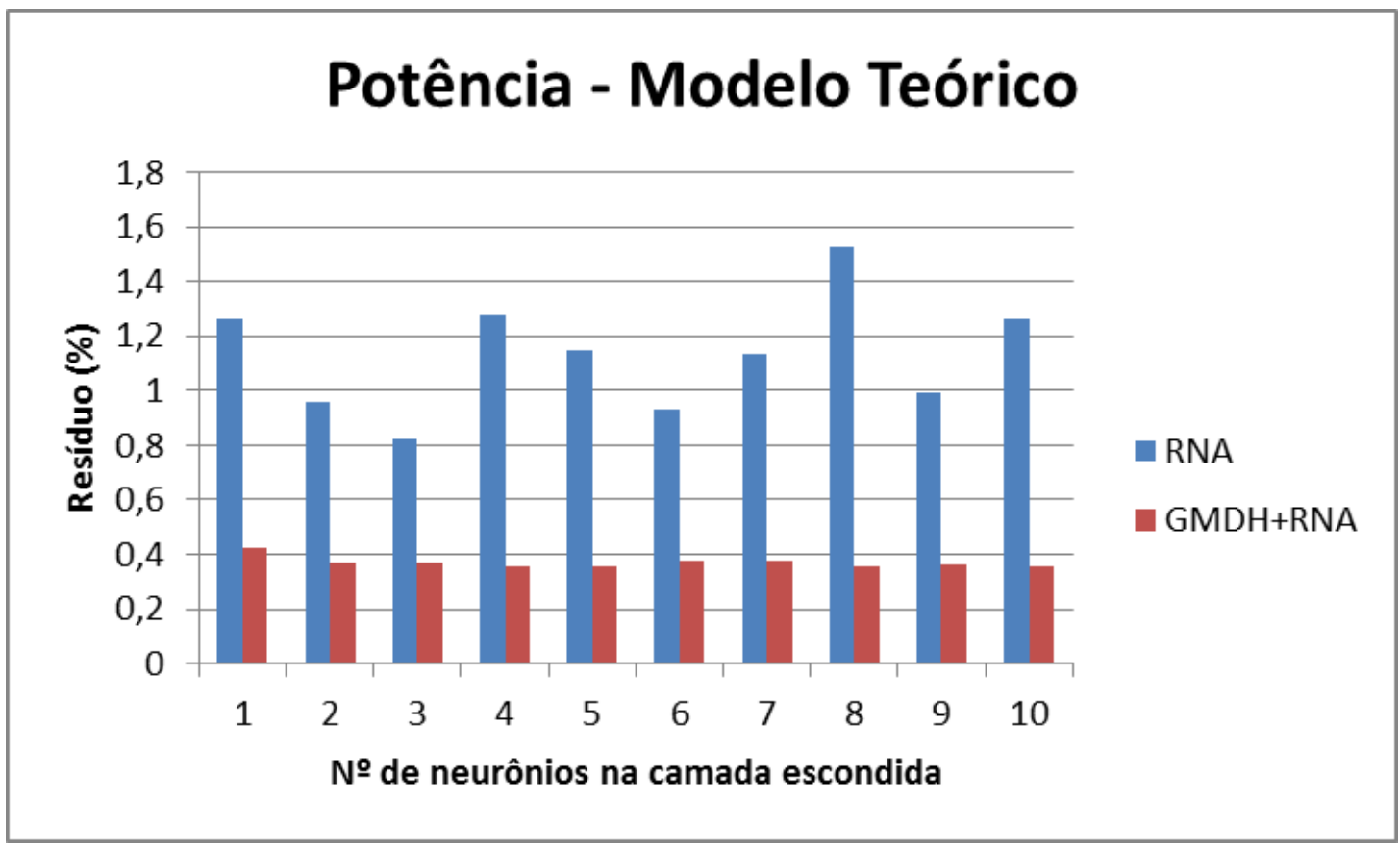

Figura 16. Monitoração de N2 - Comparação entre as metodologias

- Monitoração de T1

Para a monitoração de T1, a rede com 10 neurônios na camada escondida apresentou o menor resíduo, cujo valor foi 0,1836 (Figura 17).

Como pode ser observado na Figura a seguir, a combinação dos métodos GMDH e RNA apresentou os menores valores residuais. 


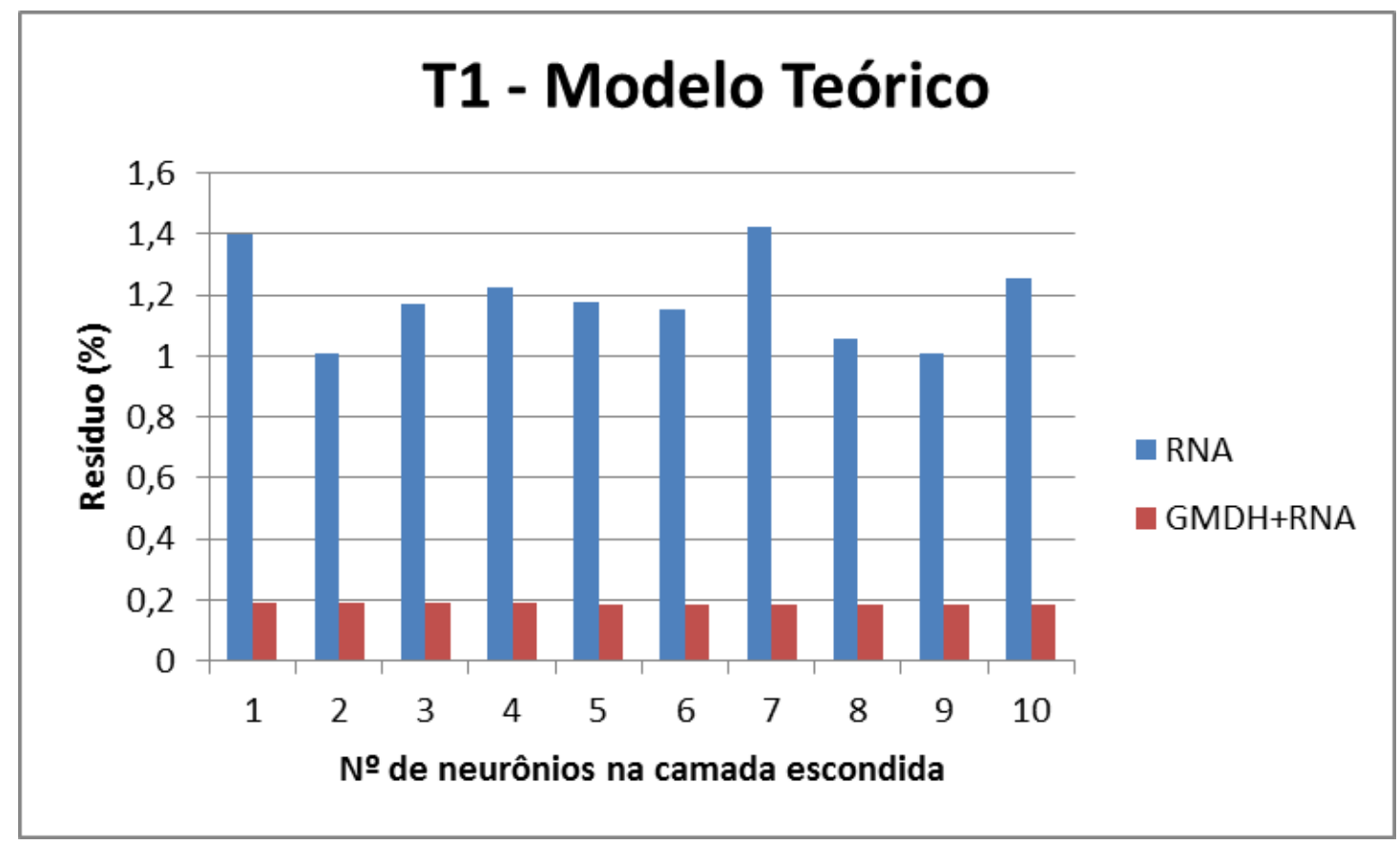

Figura 17. Monitoração de T1 - Comparação entre as metodologias

- Monitoração de T2

Para a monitoração de $\mathrm{T} 2$, a rede com 10 neurônios na camada escondida apresentou o menor resíduo, cujo valor foi 0,1796 (Figura 18).

Como pode ser observado na Figura a seguir, a combinação dos métodos GMDH e RNA apresentou os menores valores residuais.

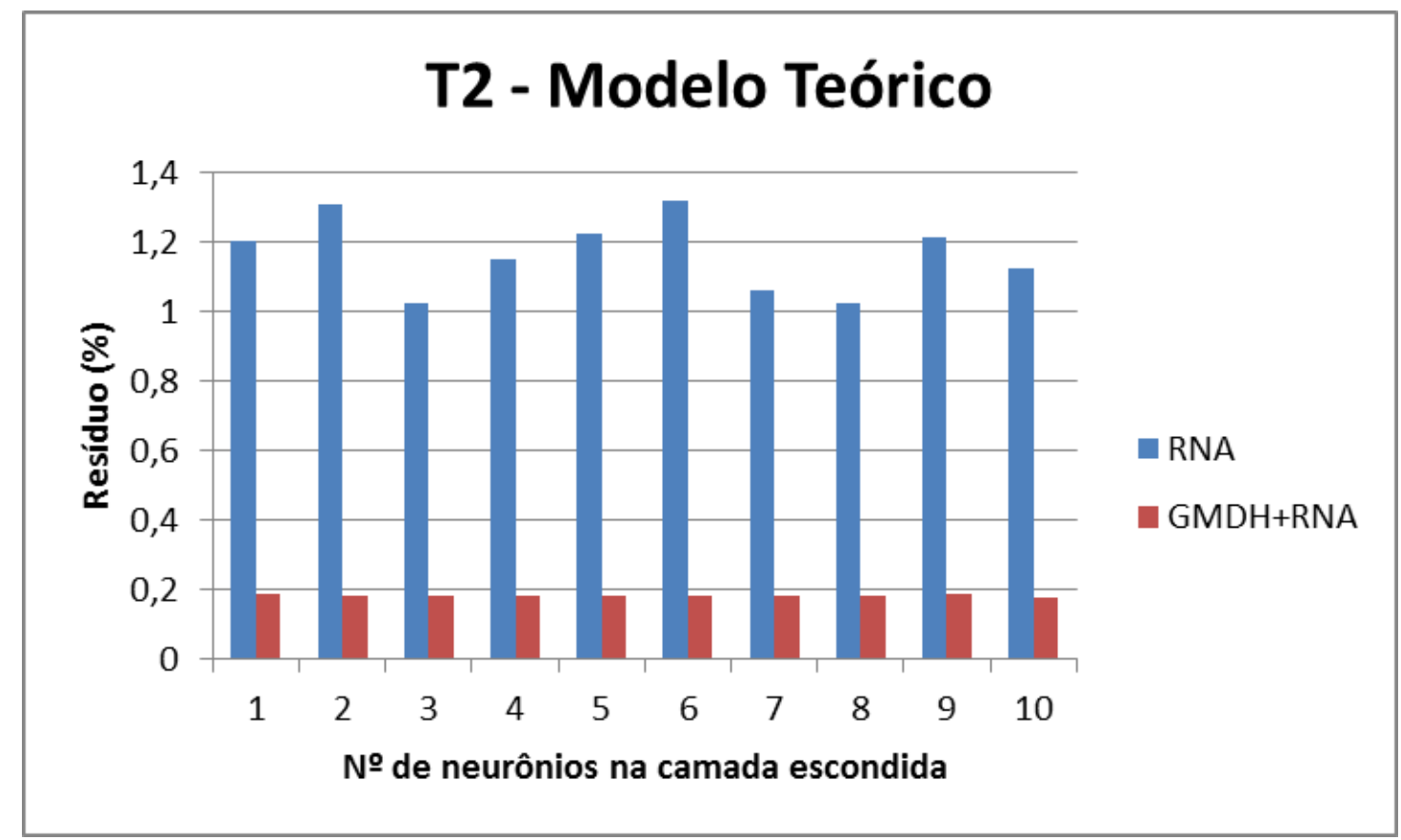

Figura 18. Monitoração de T2 - Comparação entre as metodologias 
- Monitoração de T3

Para a monitoração de $\mathrm{T} 3$, a rede com 9 neurônios na camada escondida apresentou o menor resíduo, cujo valor foi 0,2591 (Figura 19).

Como pode ser observado na Figura a seguir, a combinação dos métodos GMDH e RNA apresentou os menores valores residuais.

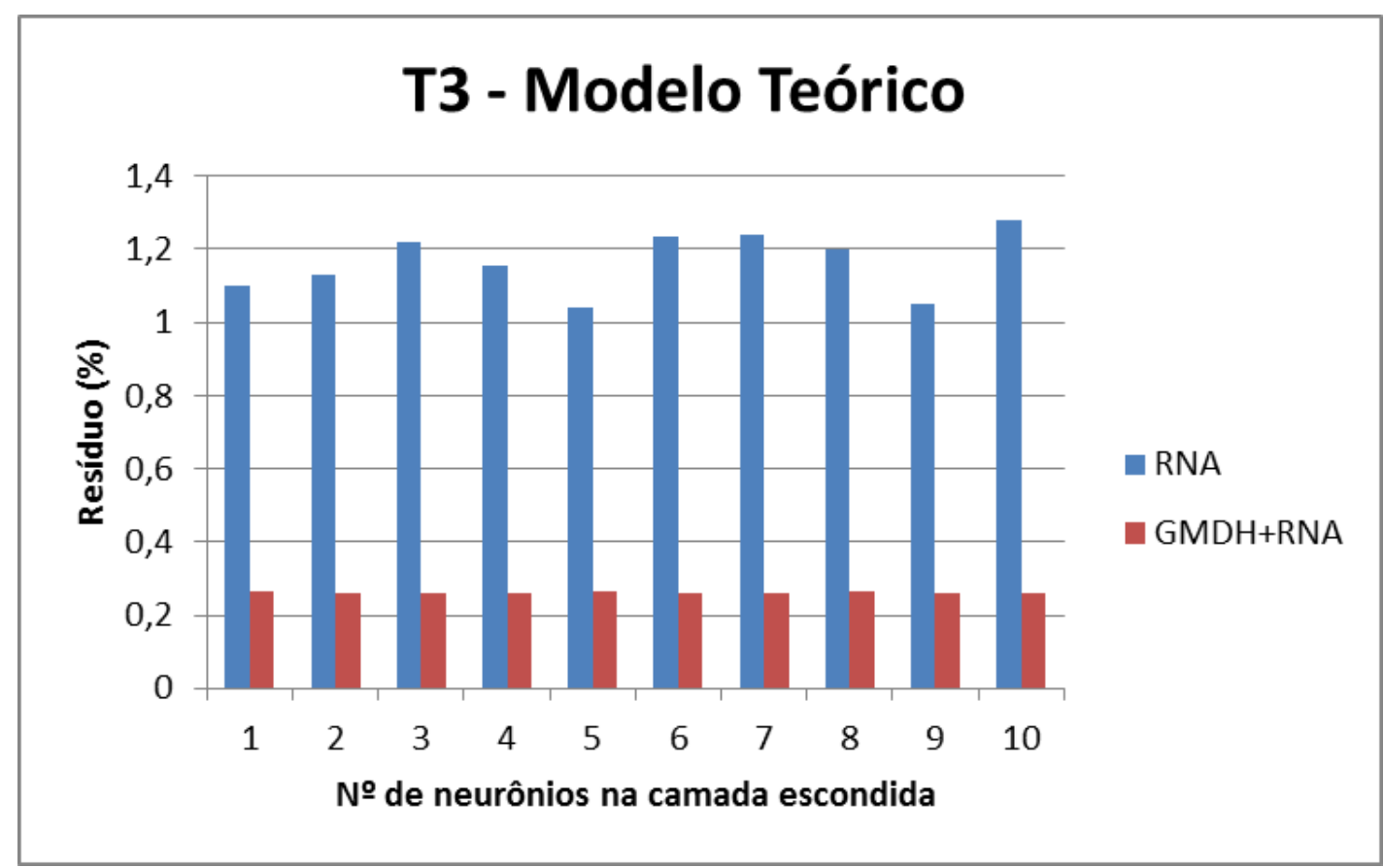

Figura 19. Monitoração de T3 - Comparação entre as metodologias

\section{- Monitoração de T4}

Para a monitoração de T4, a rede com 10 neurônios na camada escondida apresentou o menor resíduo, cujo valor foi 0,2056 (Figura 20).

Como pode ser observado na Figura a seguir, a combinação dos métodos GMDH e RNA apresentou os menores valores residuais. 


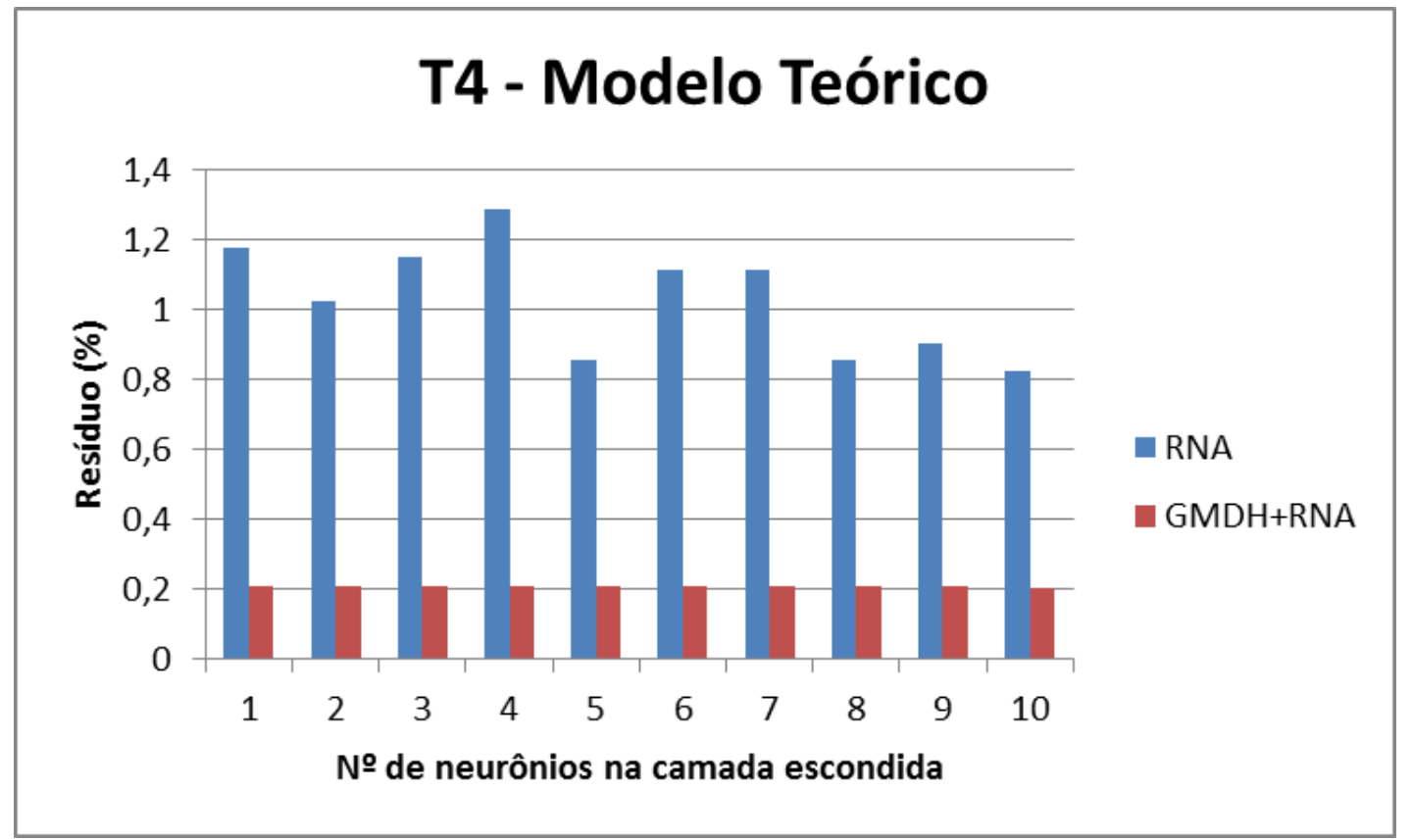

Figura 20. Monitoração de T4 - Comparação entre as metodologias

\section{- Monitoração de T6}

Para a monitoração de T6, a rede com 10 neurônios na camada escondida apresentou o menor resíduo, cujo valor foi 0,2045 (Figura 21). Como pode ser observado na Figura a seguir, a combinação dos métodos GMDH e RNA apresentou os menores valores residuais.

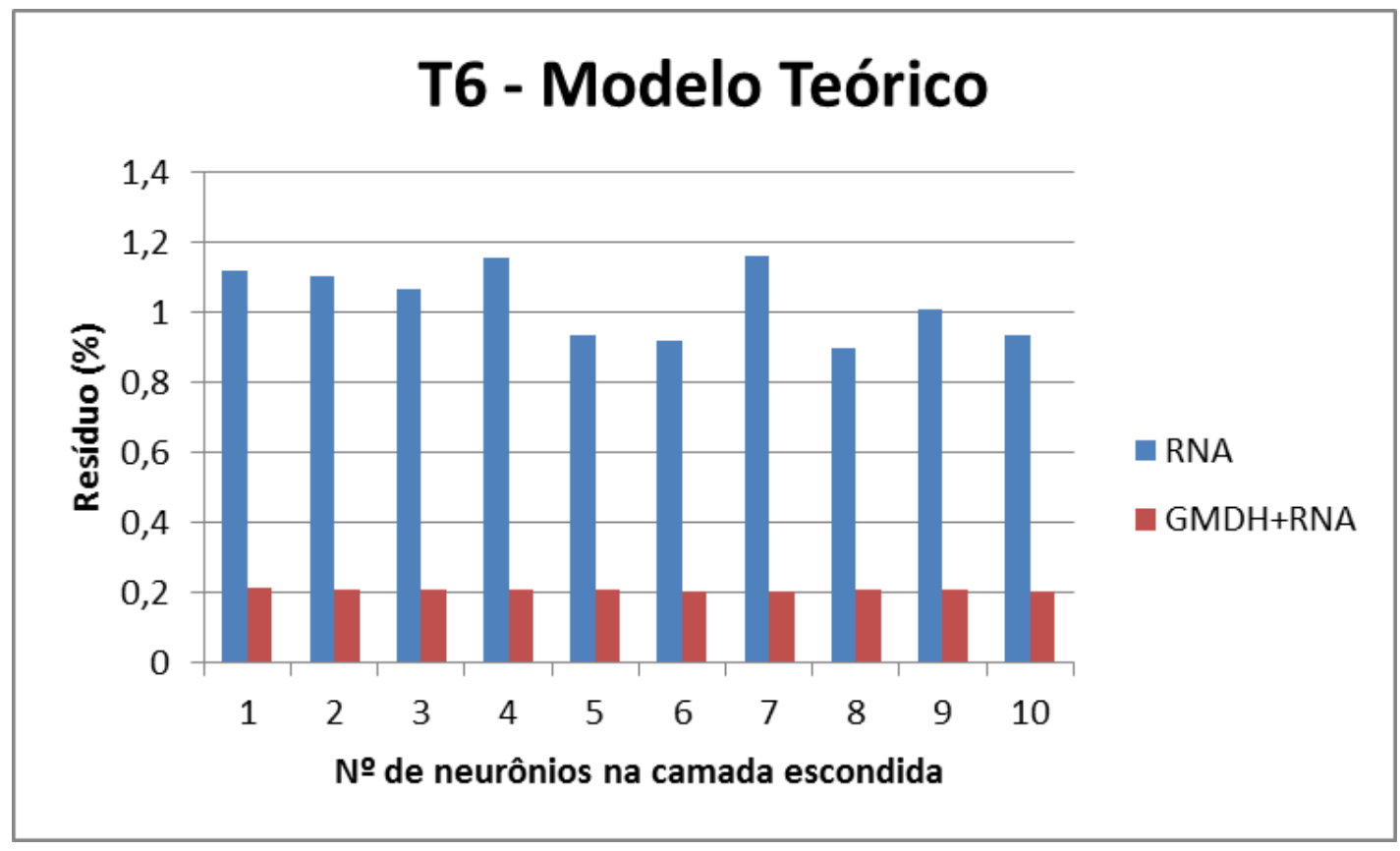

Figura 21. Monitoração de T6 - Comparação entre as metodologias 
- Monitoração de T7

Para a monitoração de T7, a rede com 7 neurônios na camada escondida apresentou o menor resíduo, cujo valor foi 0,1770 (Figura 22).

Como pode ser observado na Figura a seguir, a combinação dos métodos GMDH e RNA apresentou os menores valores residuais.

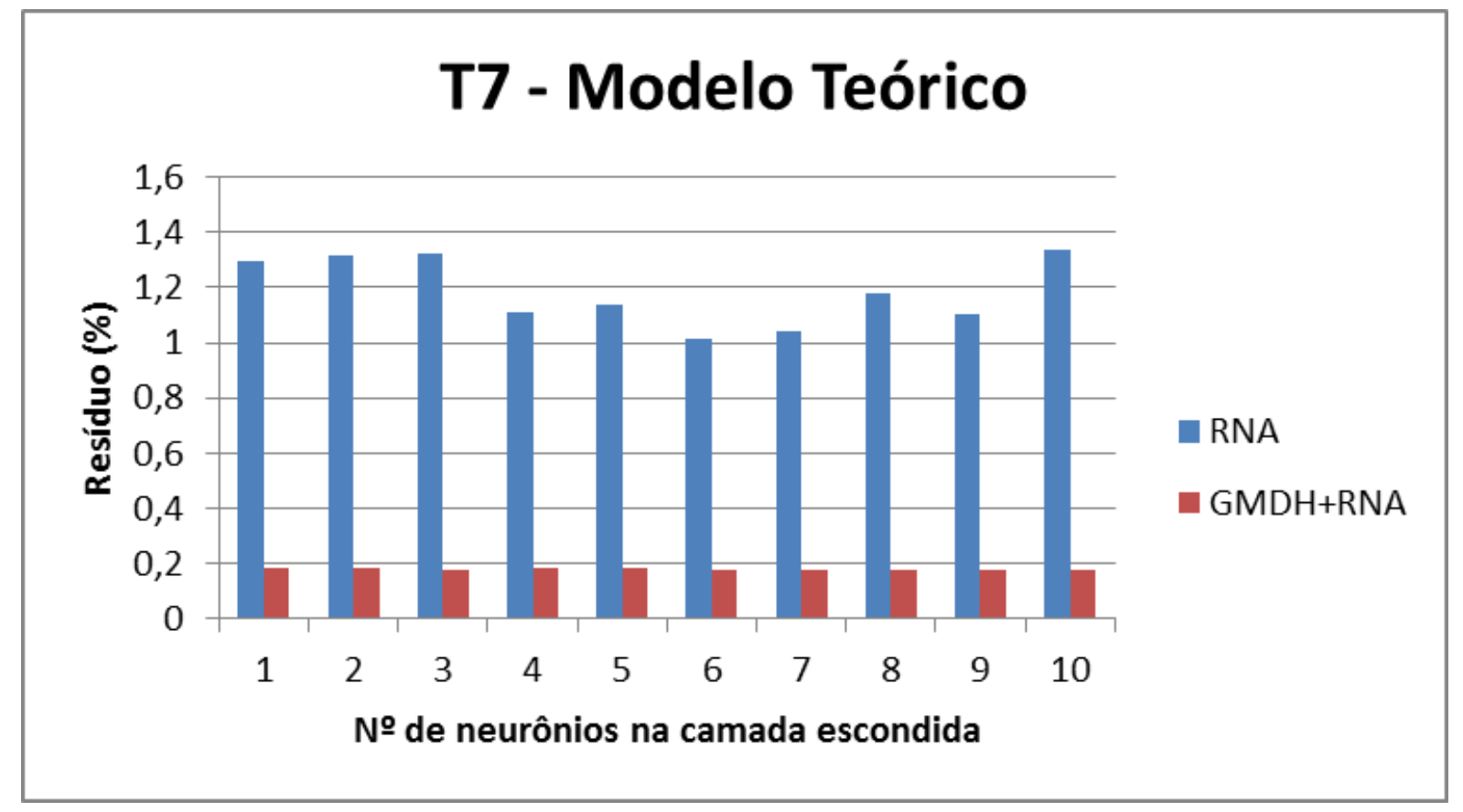

Figura 22. Monitoração de T7 - Comparação entre as metodologias

\section{- Monitoração de T8}

Para a monitoração de T8, a rede com 10 neurônios na camada escondida apresentou o menor resíduo, cujo valor foi 0,1462 (Figura 23). A variável T8 é a temperatura na entrada do secundário do trocador de calor A e apresenta um valor constante, independente da potência de operação do reator. Por este motivo, as redes treinadas para a monitoração desta variável não convergiram ao utilizar RNA sem a etapa de pré-processamento. 


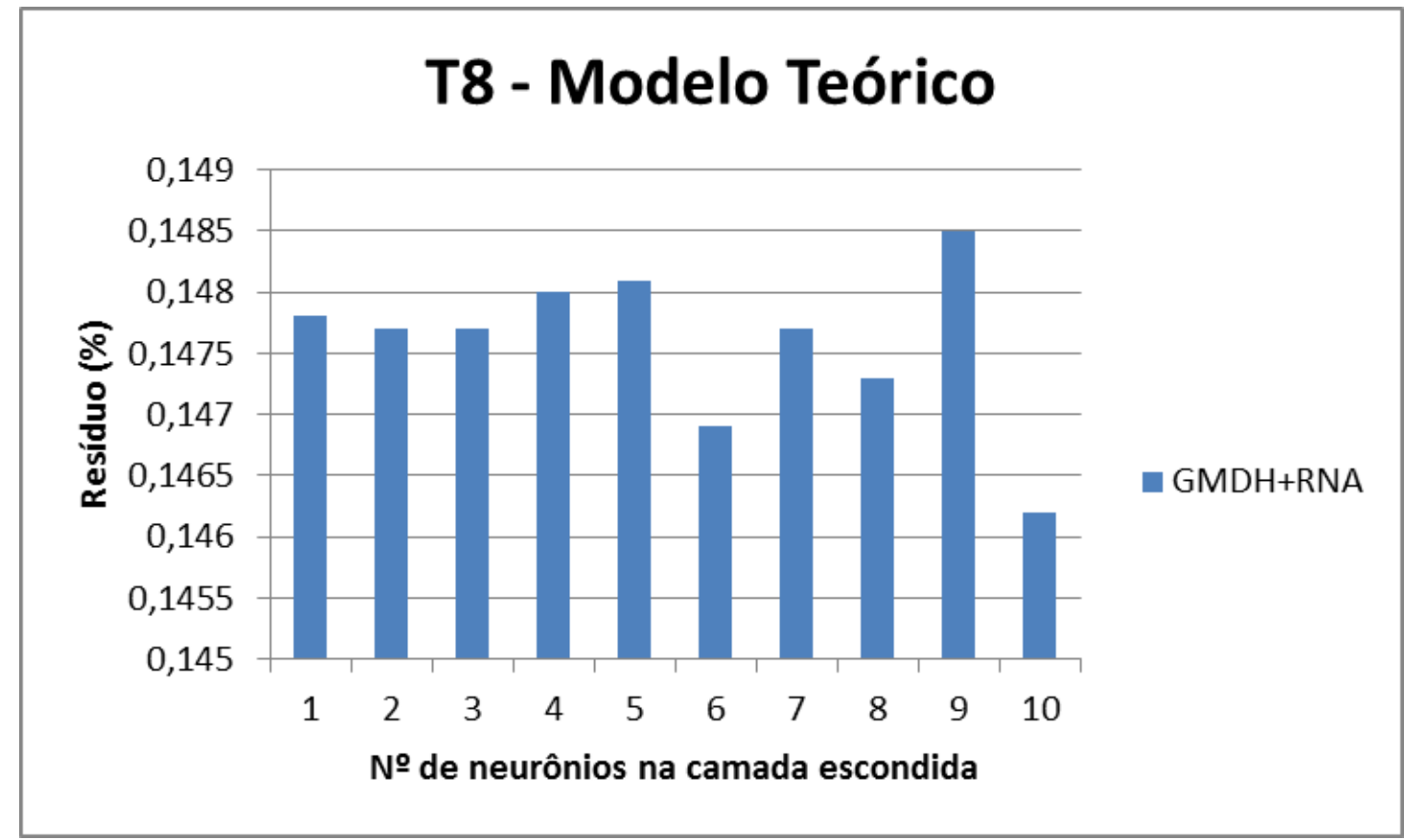

Figura 23. Monitoração de T8 - Comparação entre as metodologias

Como pode ser observado na Figura acima, a combinação dos métodos GMDH e RNA apresentou valores residuais abaixo de $0,15 \%$.

- Monitoração de T9

Para a monitoração de T9, a rede com 9 neurônios na camada escondida apresentou o menor resíduo, cujo valor foi 0,1967 (Figura 24).

Como pode ser observado na Figura a seguir, a combinação dos métodos GMDH e RNA apresentou os menores valores residuais. 


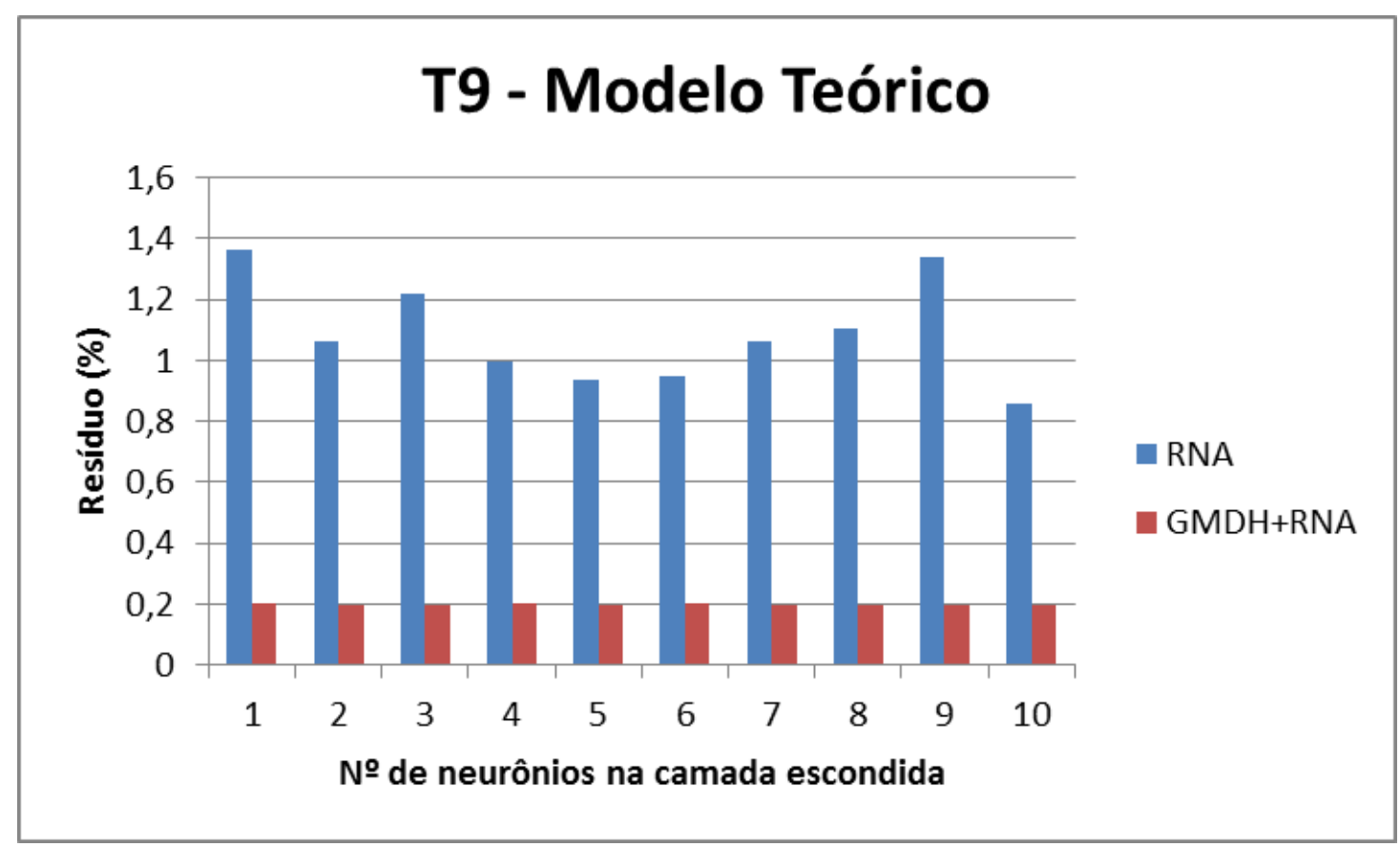

Figura 24. Monitoração de T9 - Comparação entre as metodologias

\subsubsection{Análise dos resultados obtidos}

A Tabela 3 apresenta uma síntese dos melhores resultados obtidos na monitoração das variáveis abrangidas pelo modelo 1 .

Em todos os estudos realizados neste trabalho, o número de neurônios na camada escondida da rede neural foi variado com o propósito de encontrar a melhor dimensão para as RNA, e a rede que apresentasse o menor resíduo, seria escolhida para o sistema de Monitoração.

As redes utilizadas na monitoração das variáveis de vazão F1M3 e F2M3 não convergiram, por apresentarem valores praticamente constantes, apenas flutuações ao longo da operação do reator. A monitoração da variável T8 só foi possível através da utilização de GMDH + RNA, pois ao utilizar RNA sem a etapa de pré-pocessamento, as redes não convergiram.

Tabela 3. Resultados obtidos na Monitoração - modelo 1

\begin{tabular}{|c|c|c|}
\hline \multirow{2}{*}{ Variável monitorada } & \multicolumn{2}{|c|}{ Resíduo (\%) } \\
\cline { 2 - 3 } & RNA & GMDH + RNA \\
\hline T1 & 1,0059 & $\mathbf{0 , 1 8 3 6}$ \\
\hline T2 & 1,0233 & $\mathbf{0 , 1 7 9 6}$ \\
\hline
\end{tabular}




\begin{tabular}{|c|c|c|}
\hline \multirow{2}{*}{ Variável monitorada } & \multicolumn{2}{|c|}{ Resíduo (\%) } \\
\cline { 2 - 3 } & RNA & GMDH + RNA \\
\hline T3 & 1,0416 & $\mathbf{0 , 2 5 9 1}$ \\
\hline T4 & 0,8219 & $\mathbf{0 , 2 0 5 6}$ \\
\hline T6 & 0,9340 & $\mathbf{0 , 2 0 4 5}$ \\
\hline T7 & 1,0141 & $\mathbf{0 , 1 7 7 0}$ \\
\hline T8 & ---------- & 0,1462 \\
\hline T9 & 0,8582 & $\mathbf{0 , 1 9 6 7}$ \\
\hline N2 & 0,8221 & $\mathbf{0 , 3 5 6 7}$ \\
\hline F1M3 & ---------- & ---------- \\
\hline F2M3 & ---------- & ----------- \\
\hline
\end{tabular}

Através da análise desta tabela, verifica-se que:

a monitoração através da combinação de GMDH + RNA apresentou resíduos menores do que os obtidos usando apenas RNA.

\subsubsection{Modelo 2 - dados de operação do reator}

As variáveis abrangidas pelo modelo 2 são: N2, F1M3, F2M3, R1M3, T3, T4, T7, T8 e T9.

Para a monitoração das variáveis do modelo 2 , o procedimento foi o mesmo utilizado anteriormente, ou seja, foram treinadas 10 RNA, variando-se o número de neurônios na camada escondida de 1 a 10. A camada de entrada foi alimentada por uma nova estimativa das variáveis de entrada (matriz_z) obtida através do algoritmo GMDH. As Figuras 25 a 31 apresentam os resultados de monitoração do modelo 2.

\section{- Potência (N2)}

Na monitoração da potência, a rede que apresentou o menor resíduo foi a rede com 2 neurônios na camada escondida, cujo valor residual foi de 0,4755 (Figura 25). Como pode ser observado na Figura a seguir, o método RNA apresentou os menores valores residuais, na maioria dos casos simulados. 


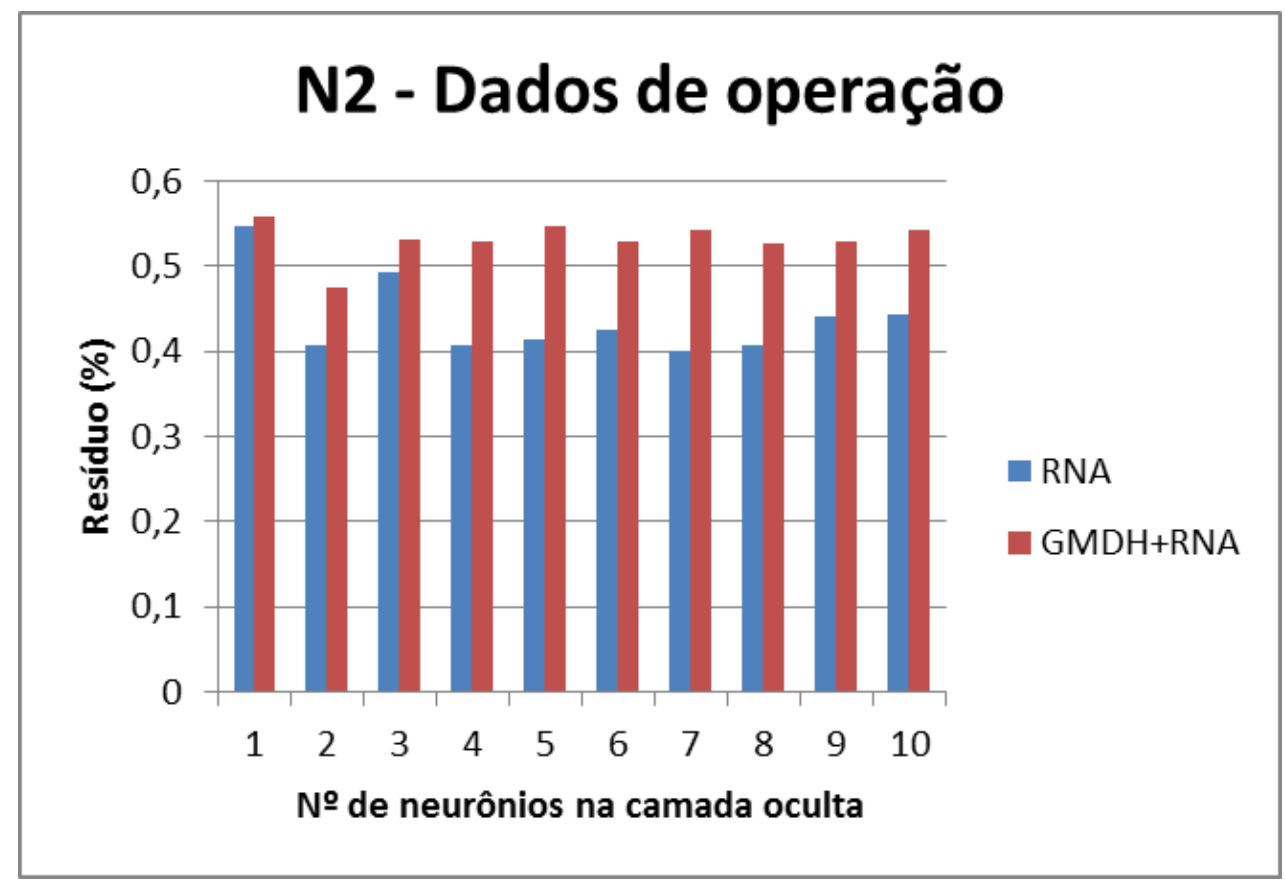

Figura 25. Monitoração de N2 - Comparação entre as metodologias

- Monitoração de T3

Para a monitoração de T3, a rede com 8 neurônios na camada escondida apresentou o menor resíduo, cujo valor foi 0,5829 (Figura 26).

Como pode ser observado na Figura a seguir, a combinação dos métodos GMDH e RNA apresentou os menores valores residuais, na maioria dos casos simulados. 


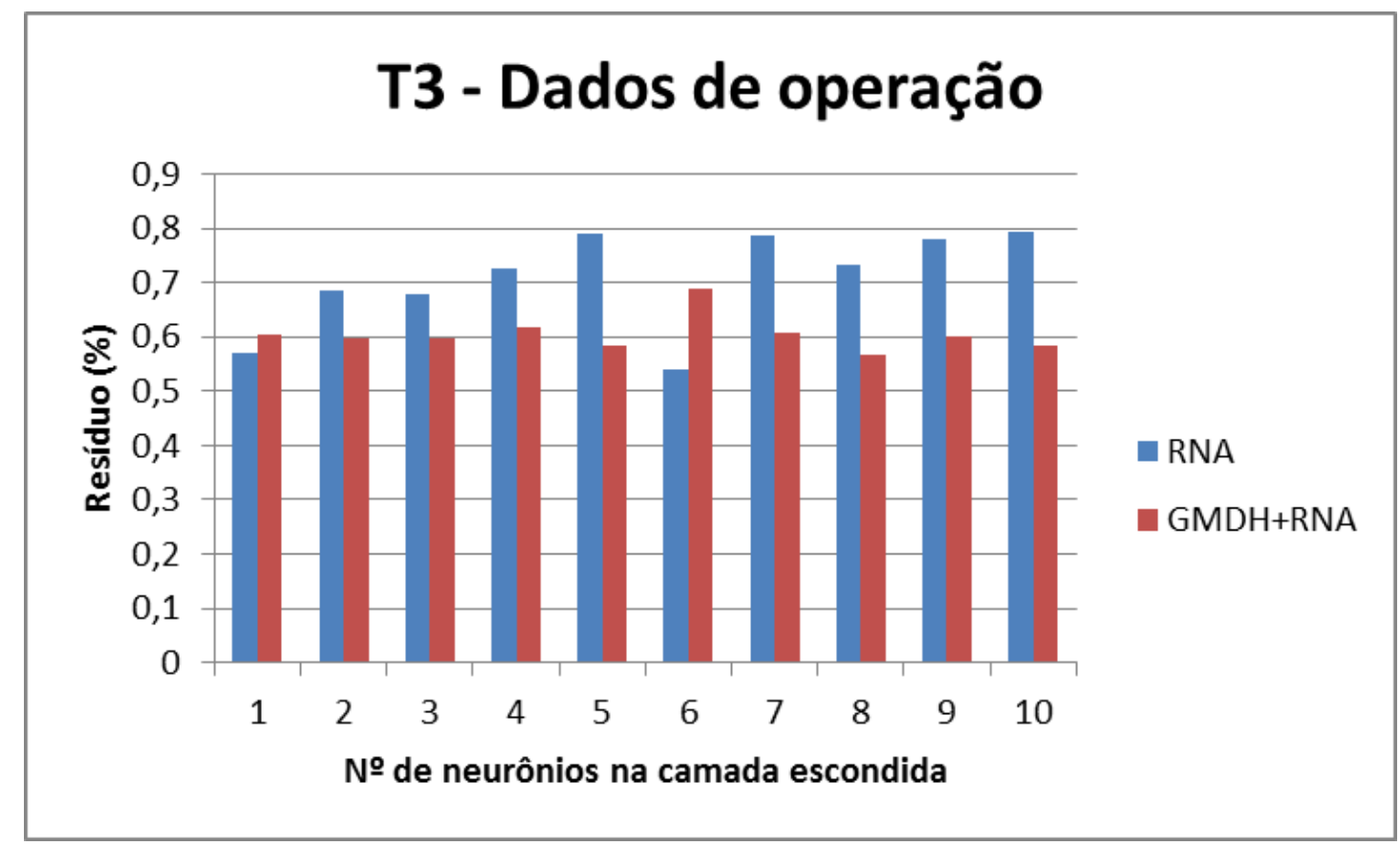

Figura 26. Monitoração de T3 - Comparação entre as metodologias

- Monitoração de T4

Para a monitoração de T4, a rede com 10 neurônios na camada escondida apresentou o menor resíduo, cujo valor foi 0,4354 (Figura 27).

Como pode ser observado na Figura a seguir, a combinação dos métodos GMDH e RNA apresentou os menores valores residuais.

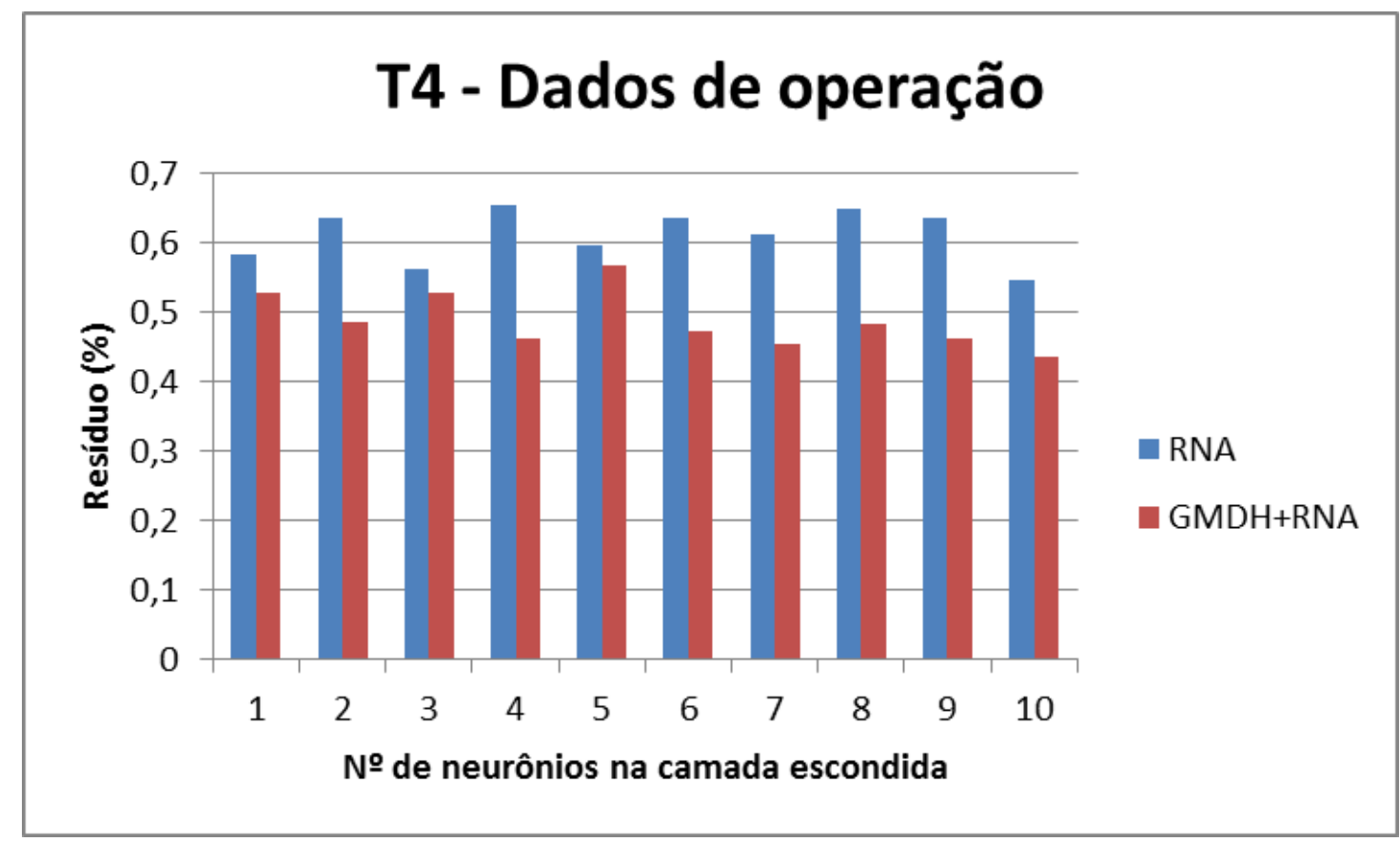

Figura 27. Monitoração de T4 - Comparação entre as metodologias 
- Monitoração de T7

Para a monitoração de T7, a rede com 7 neurônios na camada escondida apresentou o menor resíduo, cujo valor foi 0,5511 (Figura 28).

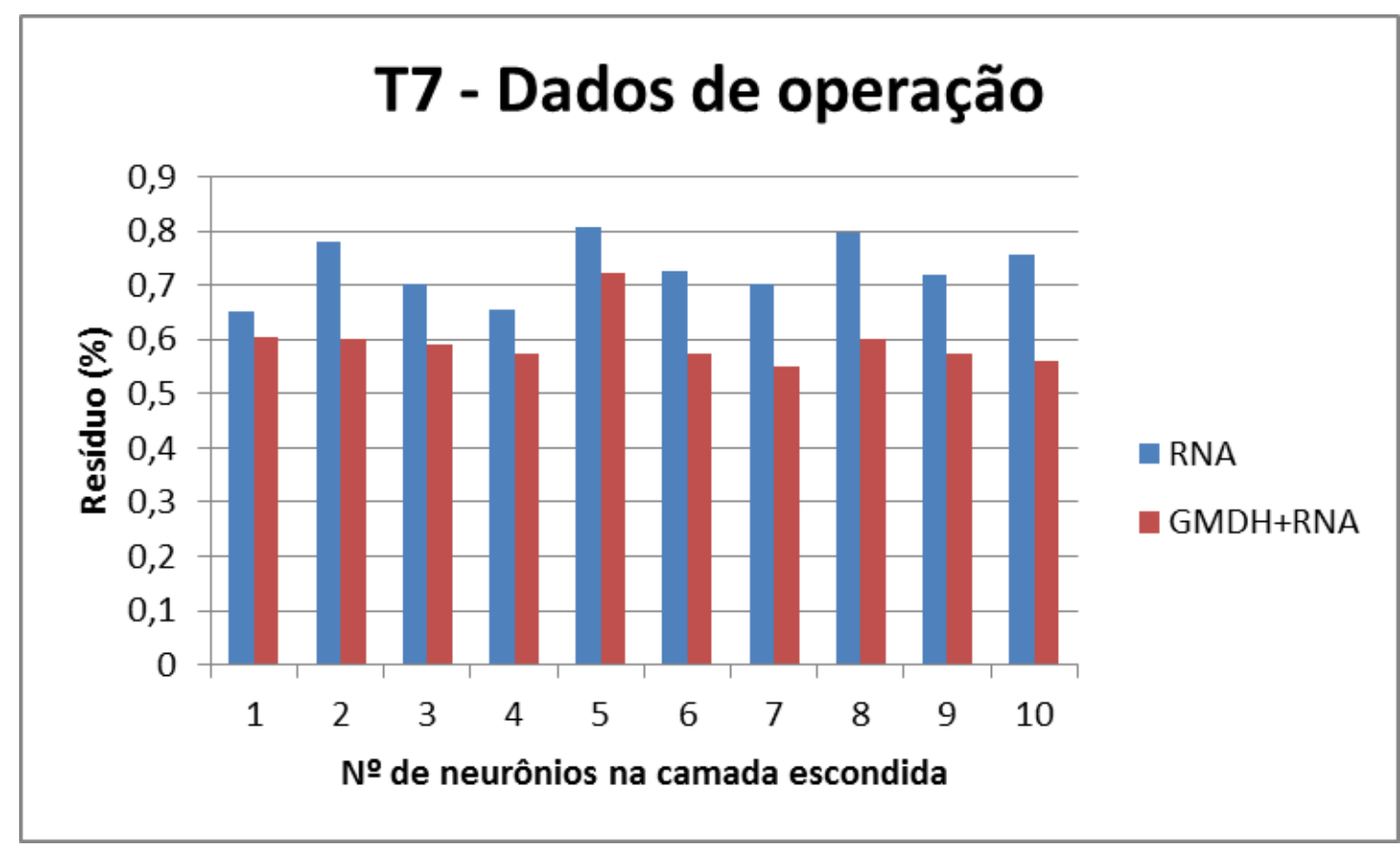

Figura 28. Monitoração de T7 - Comparação entre as metodologias

Como pode ser observado na Figura acima, a combinação dos métodos GMDH e RNA apresentou os menores valores residuais.

\section{- Monitoração de T8}

Para a monitoração de T8, a rede com 8 neurônios na camada escondida apresentou o menor resíduo, cujo valor foi 1,0863 (Figura 29).

Como pode ser observado na Figura a seguir, a combinação dos métodos GMDH e RNA apresentou os menores valores residuais, na maioria dos casos simulados. 


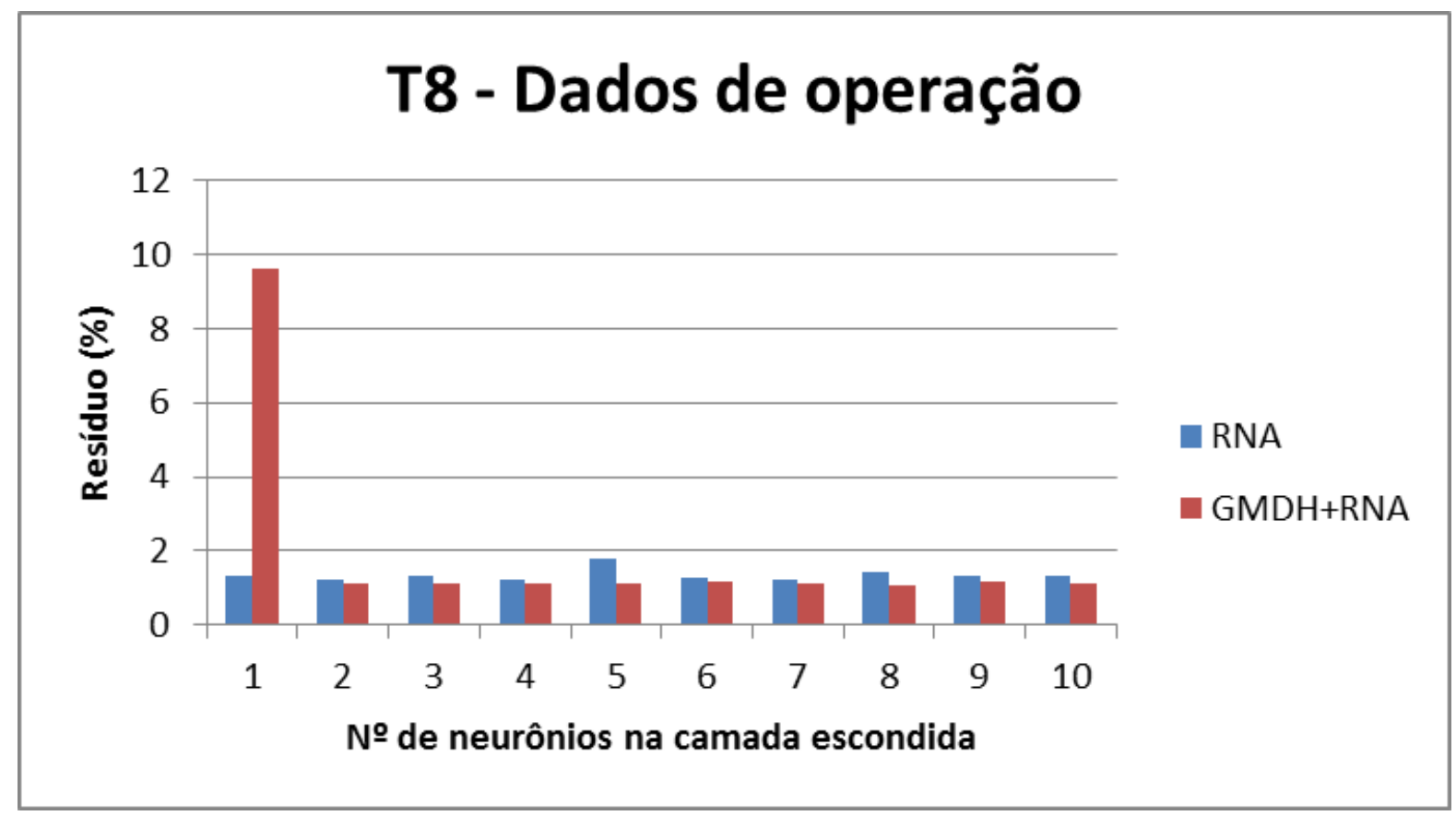

Figura 29. Monitoração de T8 - Comparação entre as metodologias

- Monitoração de T9

Para a monitoração de $\mathrm{T} 9$, a rede com 10 neurônios na camada escondida apresentou o menor resíduo, cujo valor foi 3,0104 (Figura 30). Como pode ser observado na Figura a seguir, o uso do método RNA apresentou os menores valores residuais.

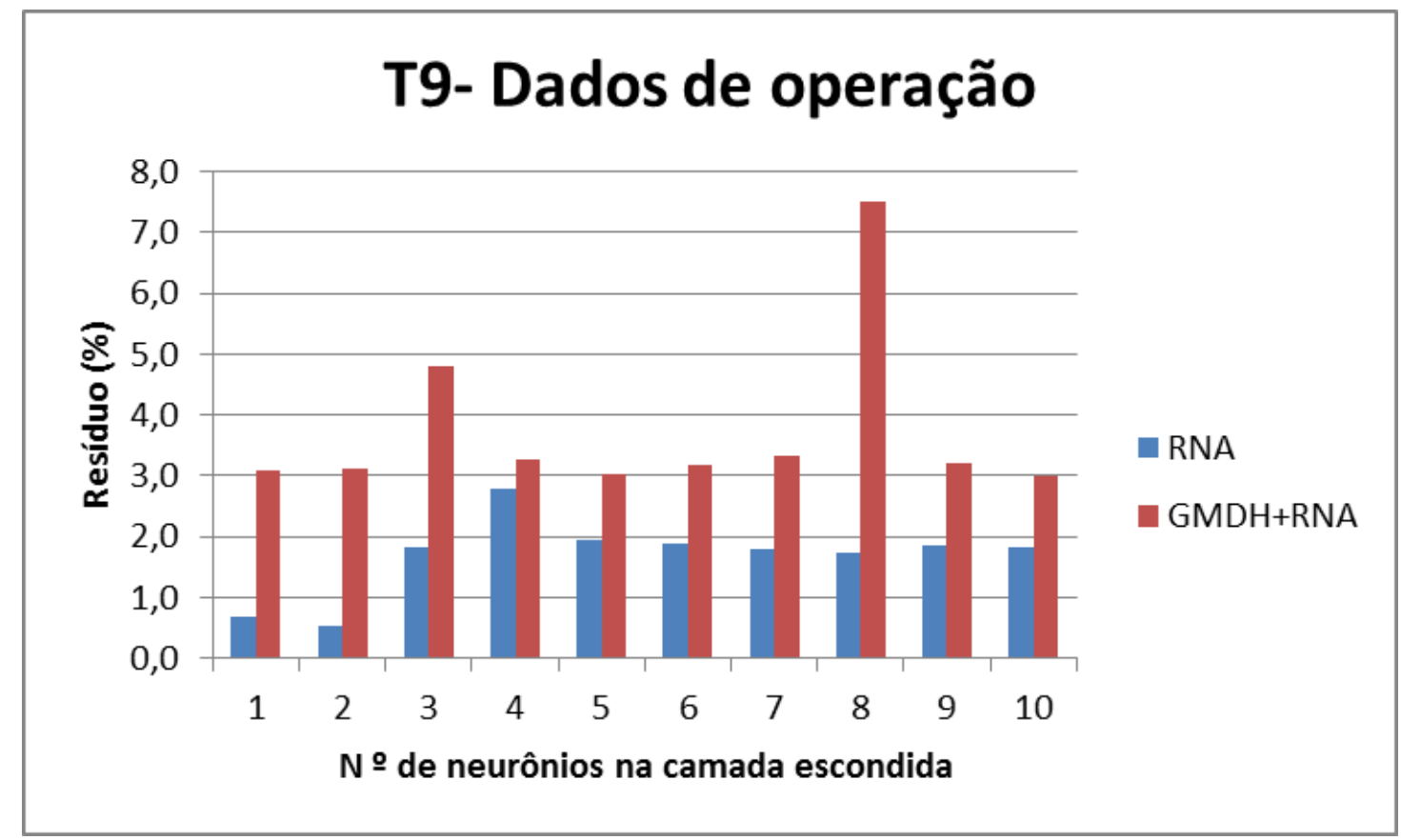

Figura 30. Monitoração de T9 - Comparação entre as metodologias 
- Monitoração de R1M3

Para a monitoração de R1M3, a rede com 7 neurônios na camada escondida apresentou o menor resíduo, cujo valor foi 4,2359 (Figura 31).

Como pode ser observado na Figura a seguir, o método RNA apresentou os menores valores residuais.

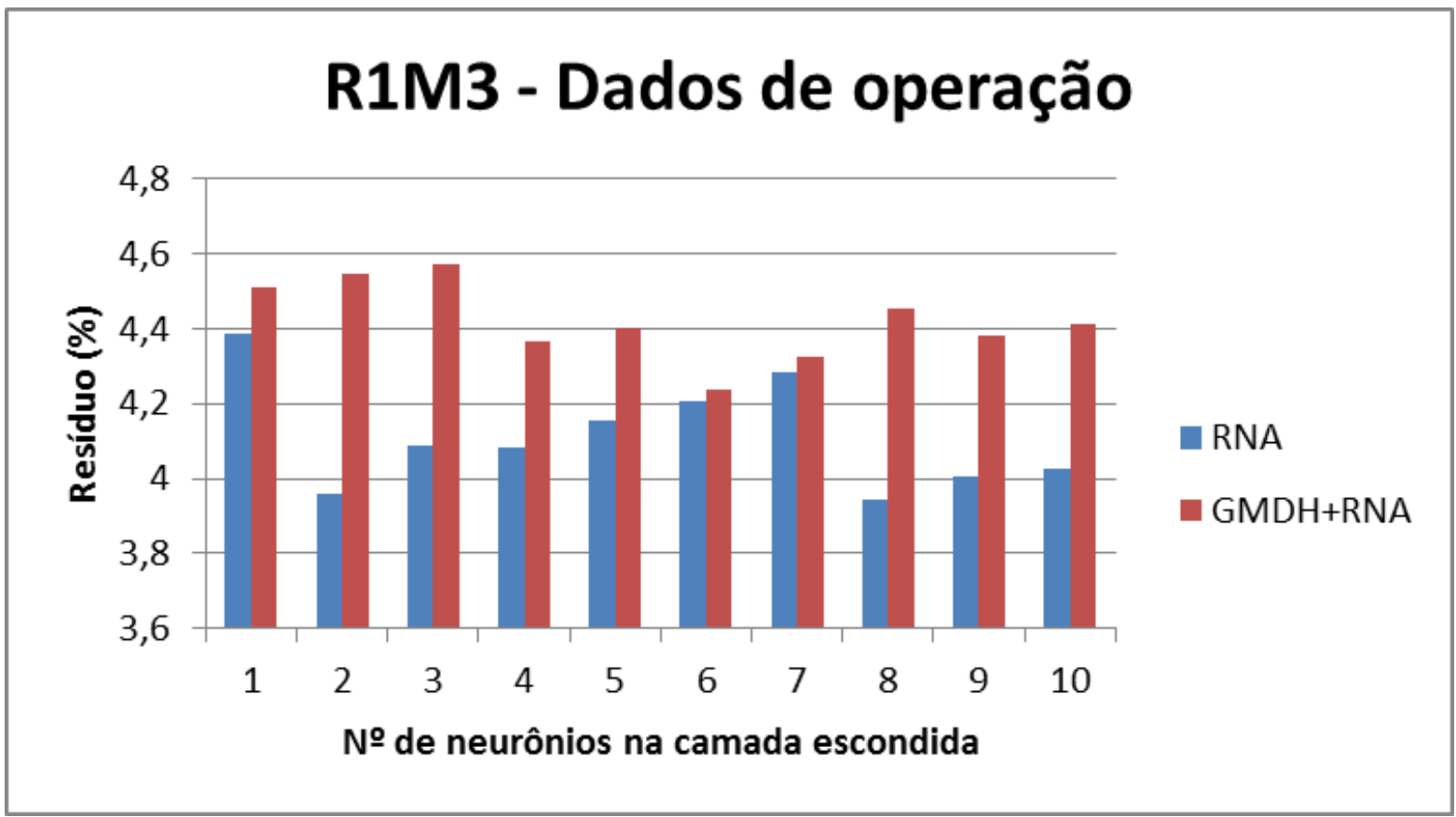

Figura 31. Monitoração de R1M3 - Comparação entre as metodologias

\subsubsection{Análise dos resultados obtidos}

A Tabela 4 apresenta uma síntese dos melhores resultados obtidos na monitoração das variáveis abrangidas pelo modelo 2. Na monitoração das vazões F1M3 e F2M3 as redes não convergiram em ambas as metodologias (GMDH +RNA e RNA), pois essas variáveis apresentam flutuações ao longo da operação do reator.

Tabela 4. Resultados obtidos na Monitoração - modelo 2

\begin{tabular}{|c|c|c|}
\hline Variável monitorada & \multicolumn{2}{|c|}{ Resíduo (\%) } \\
\hline & GMDH + RNA & RNA \\
\hline T3 & $\mathbf{0 , 5 8 2 9}$ & 0,6796 \\
\hline T4 & $\mathbf{0 , 4 3 5 4}$ & 0,5453 \\
\hline
\end{tabular}




\begin{tabular}{|c|c|c|}
\hline Variável monitorada & \multicolumn{2}{|c|}{ Resíduo (\%) } \\
\hline & GMDH + RNA & RNA \\
\hline T7 & $\mathbf{0 , 5 5 1 1}$ & 0,6510 \\
\hline T8 & $\mathbf{1 , 0 8 6 3}$ & 1,2109 \\
\hline T9 & 3,0104 & $\mathbf{0 , 5 4 3 2}$ \\
\hline N2 & 0,4755 & $\mathbf{0 , 4 0 8 0}$ \\
\hline F1M3 & ----------- & ---------- \\
\hline F2M3 & ----------- & $\mathbf{3 , 9 4 3 4}$ \\
\hline R1M3 & 4,2359 & \\
\hline
\end{tabular}

Através da análise desta tabela, verifica-se que:

Monitoração de T3, T4, T7 e T8: os resíduos obtidos usando GMDH + RNA foram menores do que os obtidos usando apenas RNA;

Monitoração de T9, N2 e R1M3: os resíduos obtidos usando GMDH + RNA foram maiores do que os obtidos usando apenas RNA.

Tendo em vista os resultados obtidos neste modelo, foi proposto um terceiro modelo incluindo informações das variáveis nucleares (Z1, Z2 e Z3), para estudar os resíduos das variáveis T9 e N2. Os resultados serão apresentados no próximo tópico.

\subsection{Variáveis mais relevantes (Seleção - GMDH) e Nova estimativa das variáveis de entrada (GMDH +RNA)}

\subsubsection{Modelo 3}

As variáveis abrangidas pelo modelo 3 são: Z1, Z2, Z3, N2, F1M3, F2M3, R1M3, F2M3, T3, T4, T7, T8 e T9.

Para a monitoração das variáveis do modelo 3, o procedimento foi o mesmo utilizado anteriormente, ou seja, foram treinadas 10 RNA, variando-se o número de neurônios na camada escondida de 1 a 10. A camada de entrada foi alimentada das seguintes maneiras: por uma nova estimativa das variáveis de entrada (matriz_z) obtida através do algoritmo GMDH e pelas variáveis mais relevantes (RNA seleção). As Figuras 32 a 42 apresentam os resultados de monitoração do modelo 3. 
- Potência (N2)

Ao realizar o pré-processamento através do estudo das variáveis desconsideradas pelo GMDH, verificou-se que para a variável N2 (modelo 3), as variáveis que tiveram uma relevância maior para o GMDH foram: Z1, Z2, Z3 e T4. Essas variáveis foram utilizadas no treinamento das RNA, onde a rede com 4 neurônios na camada escondida apresentou o menor resíduo, cujo valor foi 0,5967 (Figura 32).

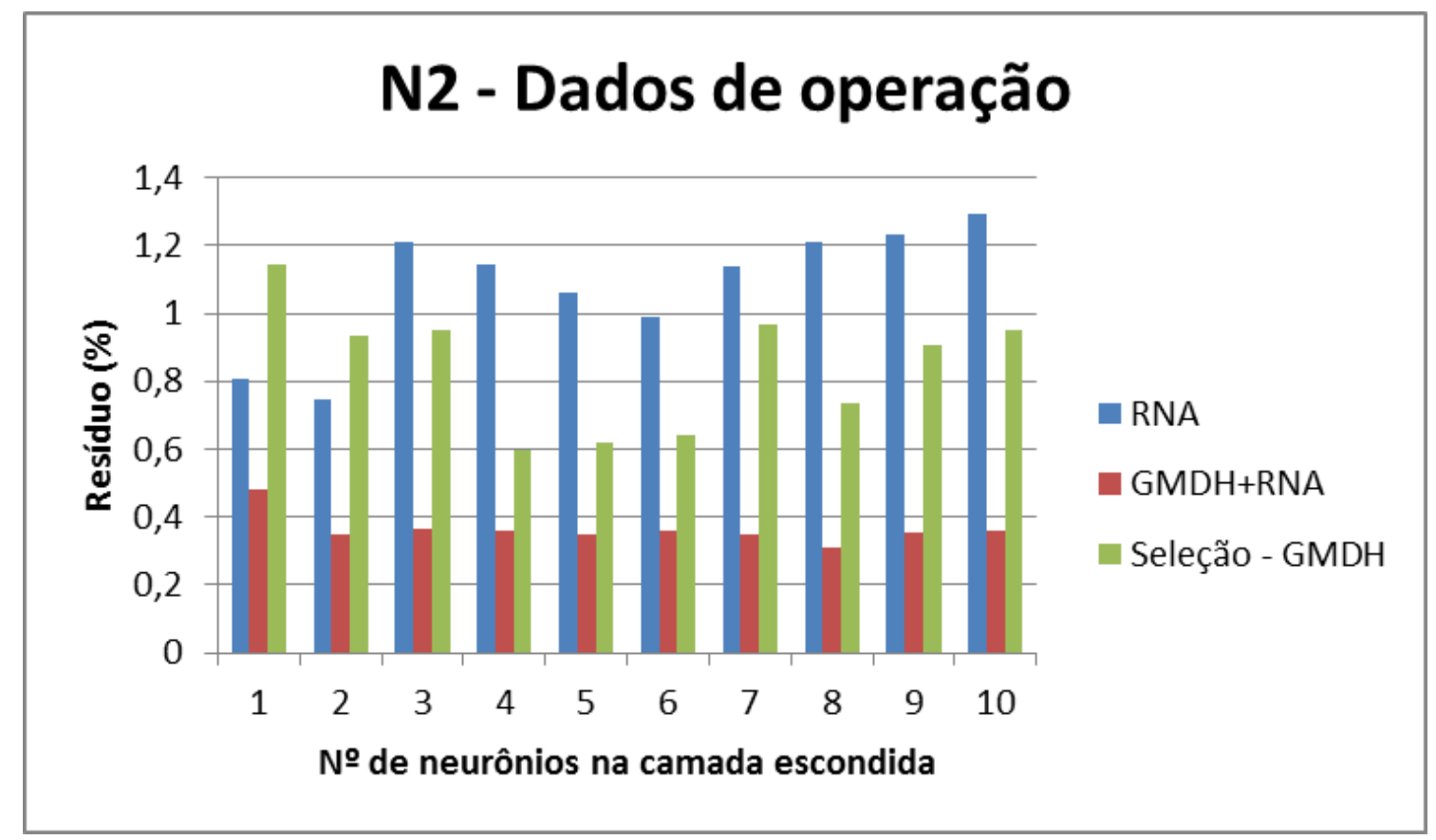

Figura 32. Monitoração de N2 - Comparação entre as metodologias

Como pode ser observado na Figura acima, a combinação dos métodos GMDH e RNA apresentou os menores valores residuais.

\section{- Monitoração de T3}

Ao realizar o pré-processamento através do estudo das variáveis desconsideradas pelo GMDH, verificou-se que para a variável T3 (modelo 3), as variáveis que tiveram uma relevância maior para o GMDH foram: Z2, Z3, T4 e T7. Essas variáveis foram utilizadas no treinamento das RNA, onde a rede com 10 neurônios na camada escondida apresentou o menor resíduo, cujo valor foi 0,3430 (Figura 33). 


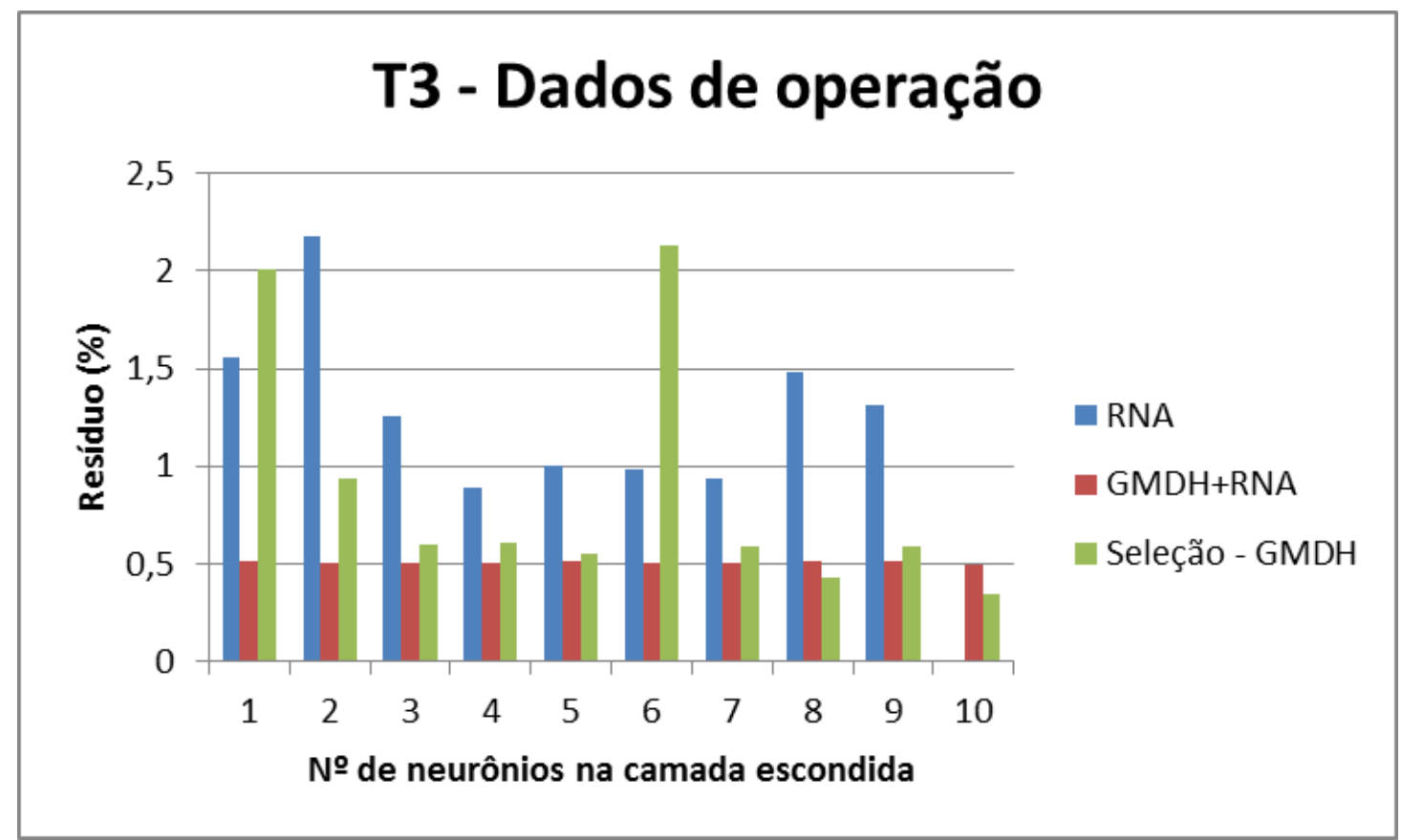

Figura 33. Monitoração de T3 - Comparação entre as metodologias

Como pode ser observado na Figura acima, a combinação dos métodos GMDH e RNA apresentou os menores valores residuais, na maioria dos casos simulados.

\section{- Monitoração de T4}

Ao realizar o pré-processamento através do estudo das variáveis desconsideradas pelo GMDH, verificou-se que para a variável T4 (modelo 3), as variáveis que tiveram uma relevância maior para o GMDH foram: Z2, Z3, T3 e T7. Essas variáveis foram utilizadas no treinamento das RNA, onde a rede com 5 neurônios na camada escondida apresentou o menor resíduo, cujo valor foi 0,2553 (Figura 34).

Como pode ser observado na Figura a seguir a combinação dos métodos GMDH e RNA apresentou os menores valores residuais, na maioria dos casos simulados. 


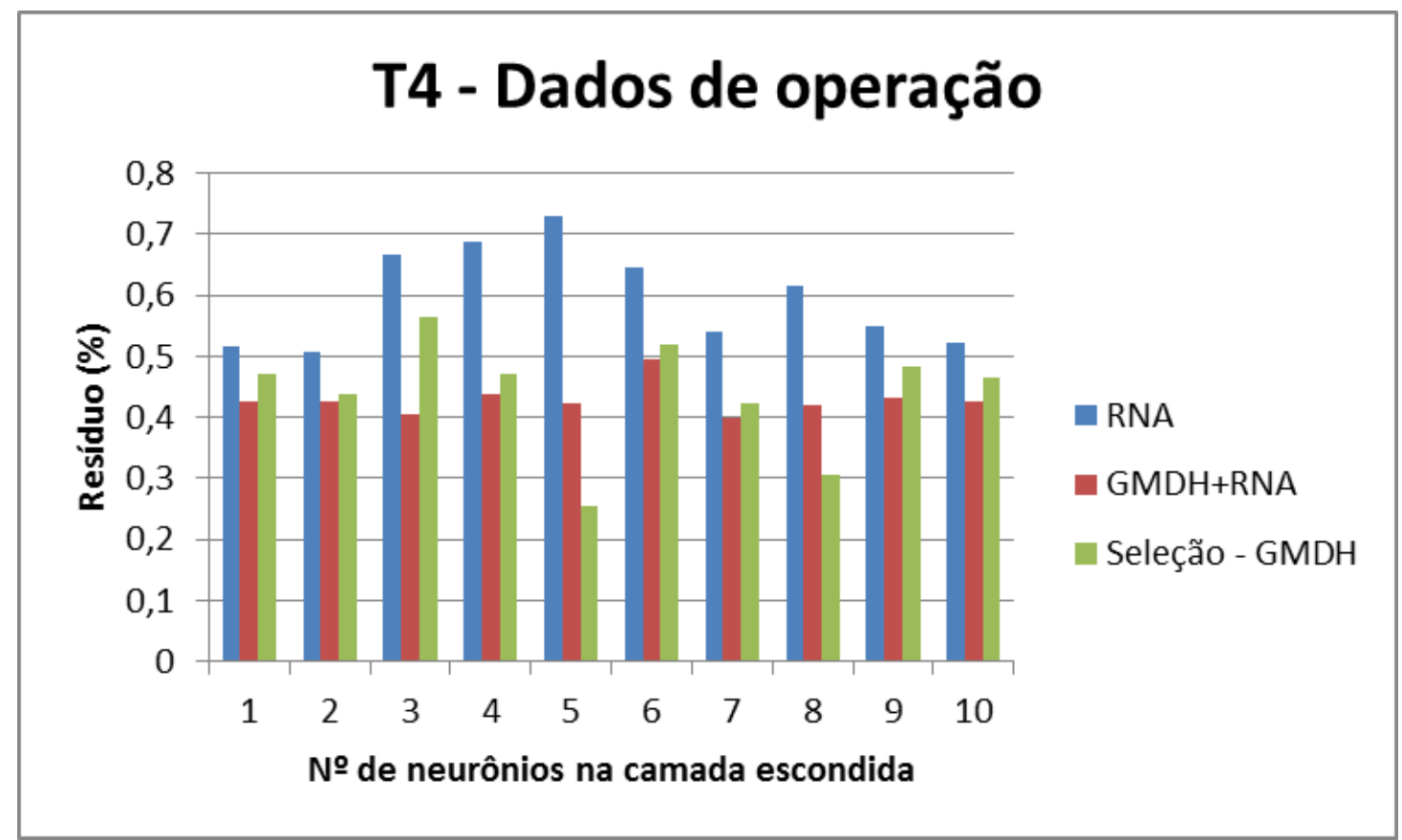

Figura 34. Monitoração de T4 - Comparação entre as metodologias

- Monitoração de T7

Ao realizar o pré-processamento através do estudo das variáveis desconsideradas pelo GMDH, verificou-se que para a variável T7 (modelo 3), as variáveis que tiveram uma relevância maior para o GMDH foram: T3, T4, T8 e T9. Essas variáveis foram utilizadas no treinamento das RNA, onde a rede com 9 neurônios na camada escondida apresentou o menor resíduo, cujo valor foi 0,3926 (Figura 35).

Como pode ser observado na Figura a seguir, o uso de Seleção - GMDH apresentou os menores valores residuais, na maioria dos casos simulados. 


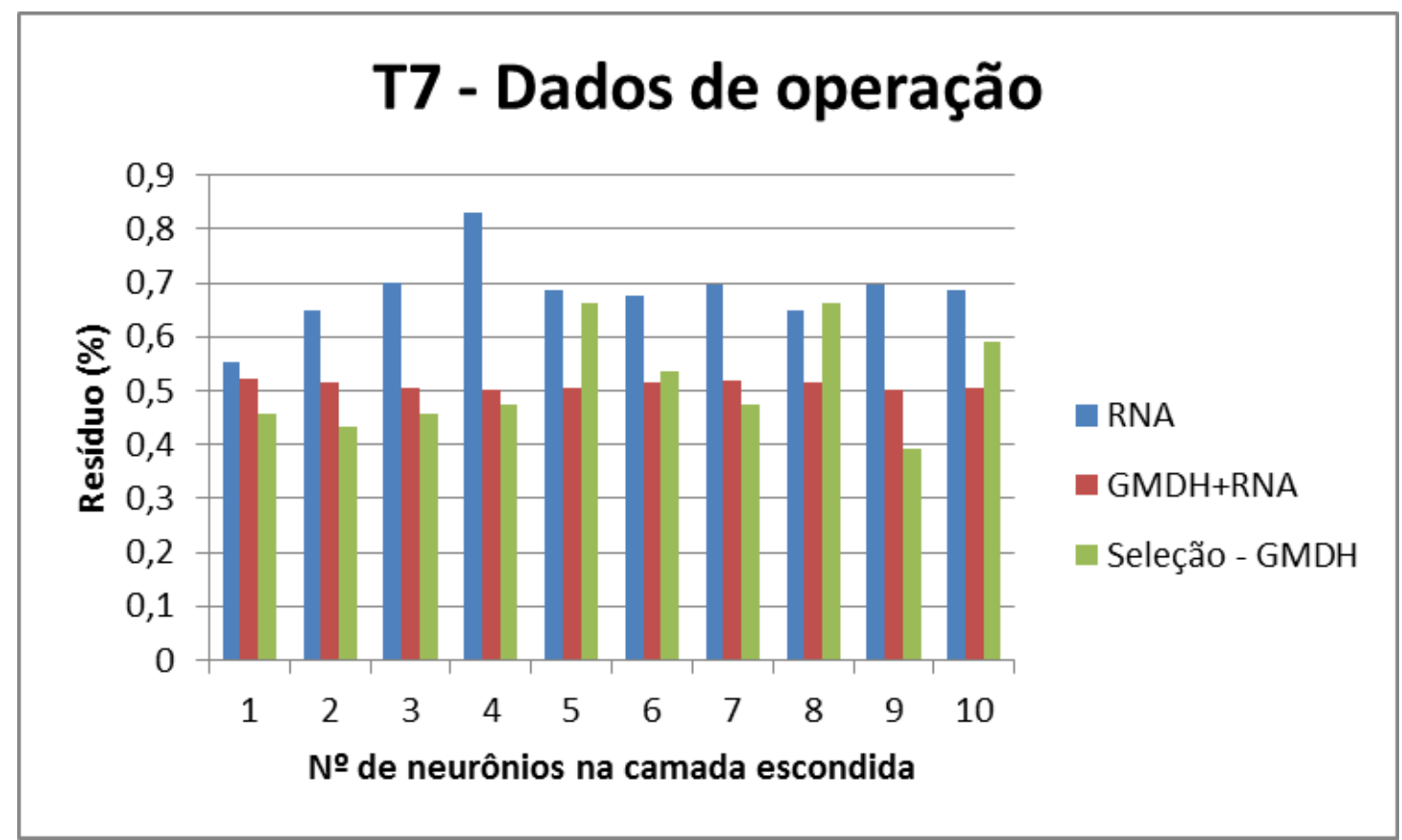

Figura 35. Monitoração de T7 - Comparação entre as metodologias

- Monitoração de T8

Ao realizar o pré-processamento através do estudo das variáveis desconsideradas pelo GMDH, verificou-se que para a variável T8 (modelo 3), as variáveis que tiveram uma relevância maior para o GMDH foram: Z1, R1M3, T7 e T9. Essas variáveis foram utilizadas no treinamento das RNA, onde a rede com 4 neurônios na camada escondida apresentou o menor resíduo, cujo valor foi 0,6642 (Figura 36).

Como pode ser observado na Figura a seguir, o uso de RNA apresentou os menores valores residuais, na maioria dos casos simulados. 


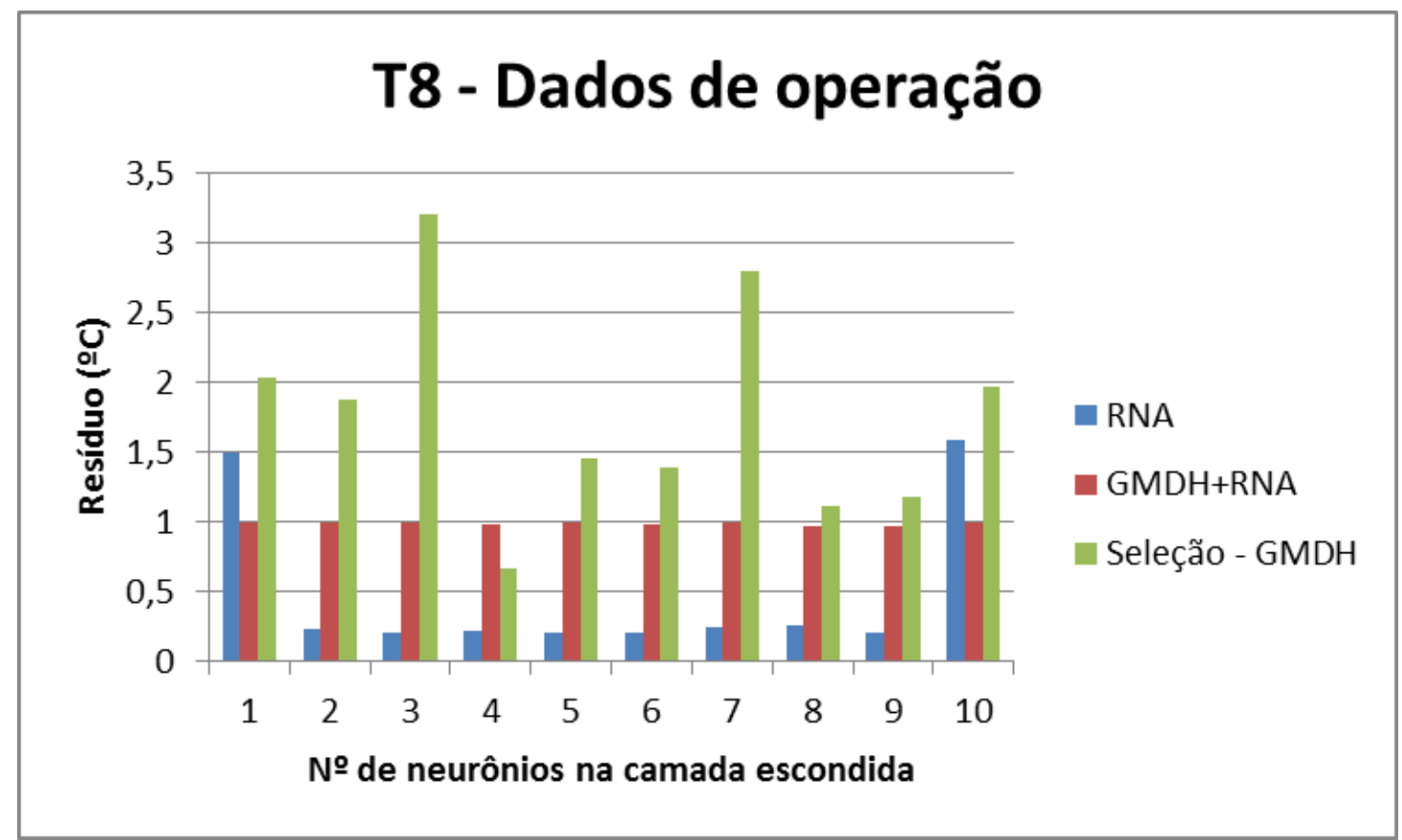

Figura 36. Monitoração de T8 - Comparação entre as metodologias

- Monitoração de T9

Ao realizar o pré-processamento através do estudo das variáveis desconsideradas pelo GMDH, verificou-se que para a variável T9 (modelo 3), as variáveis que tiveram uma relevância maior para o GMDH foram: Z1, R1M3, T7 e T8. Essas variáveis foram utilizadas no treinamento das RNA, onde a rede com 8 neurônios na camada escondida apresentou o menor resíduo, cujo valor foi 0,2982 (Figura 37).

Como pode ser observado na Figura a seguir, o uso de RNA apresentou os menores valores residuais, na maioria dos casos simulados. 


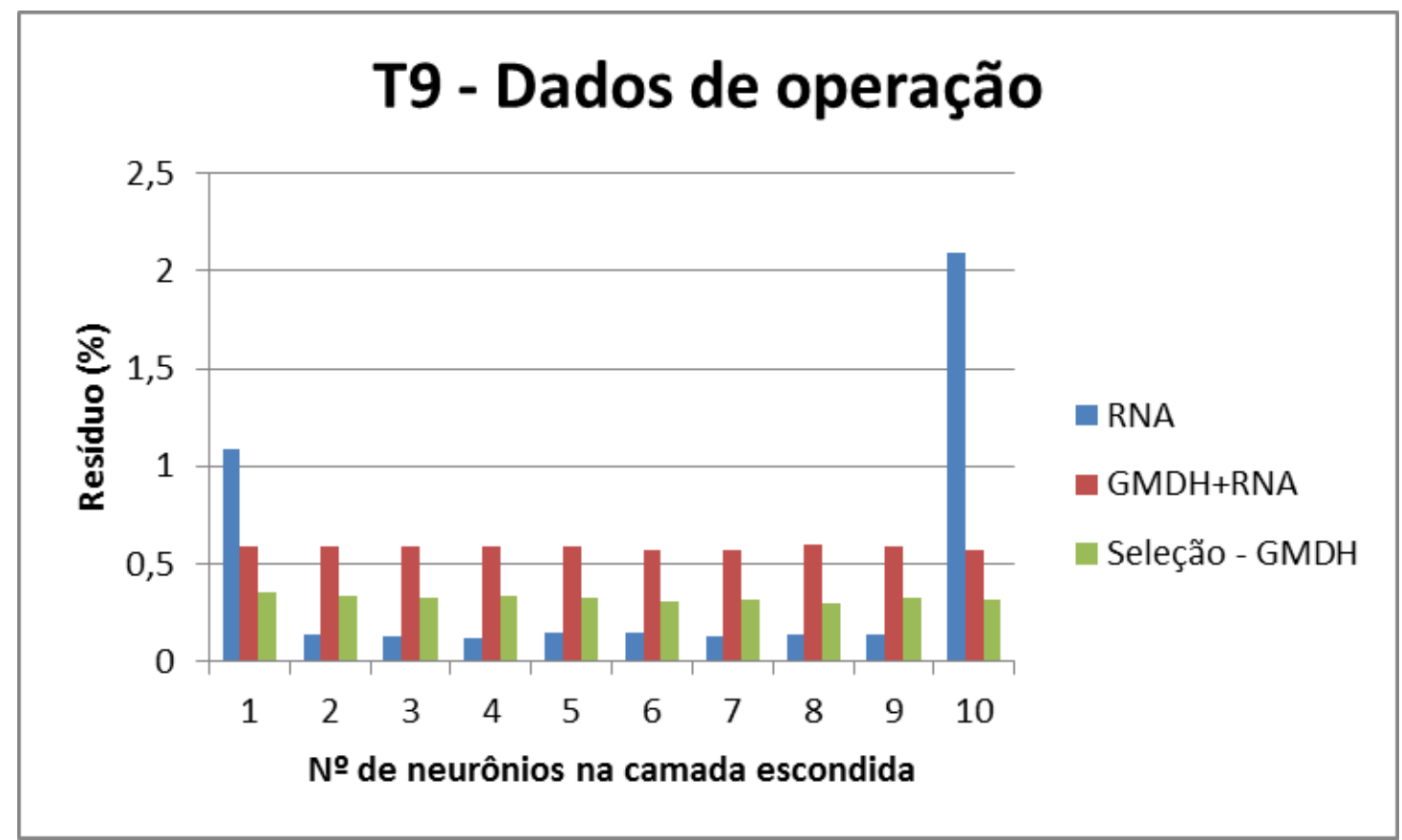

Figura 37. Monitoração de T9 - Comparação entre as metodologias

- Monitoração de R1M3

Ao realizar o pré-processamento através do estudo das variáveis desconsideradas pelo GMDH, verificou-se que para a variável R1M3(modelo 3), as variáveis que tiveram uma relevância maior para o GMDH foram: Z1, Z2, Z3, R2M3, T3, T4 e T7. Essas variáveis foram utilizadas no treinamento das RNA, onde a rede com 8 neurônios na camada escondida apresentou o menor resíduo, cujo valor foi 2,8348 (Figura $38)$.

Como pode ser observado na Figura a seguir, o uso de Seleção - GMDH apresentou os menores valores residuais, na maioria dos casos simulados. 


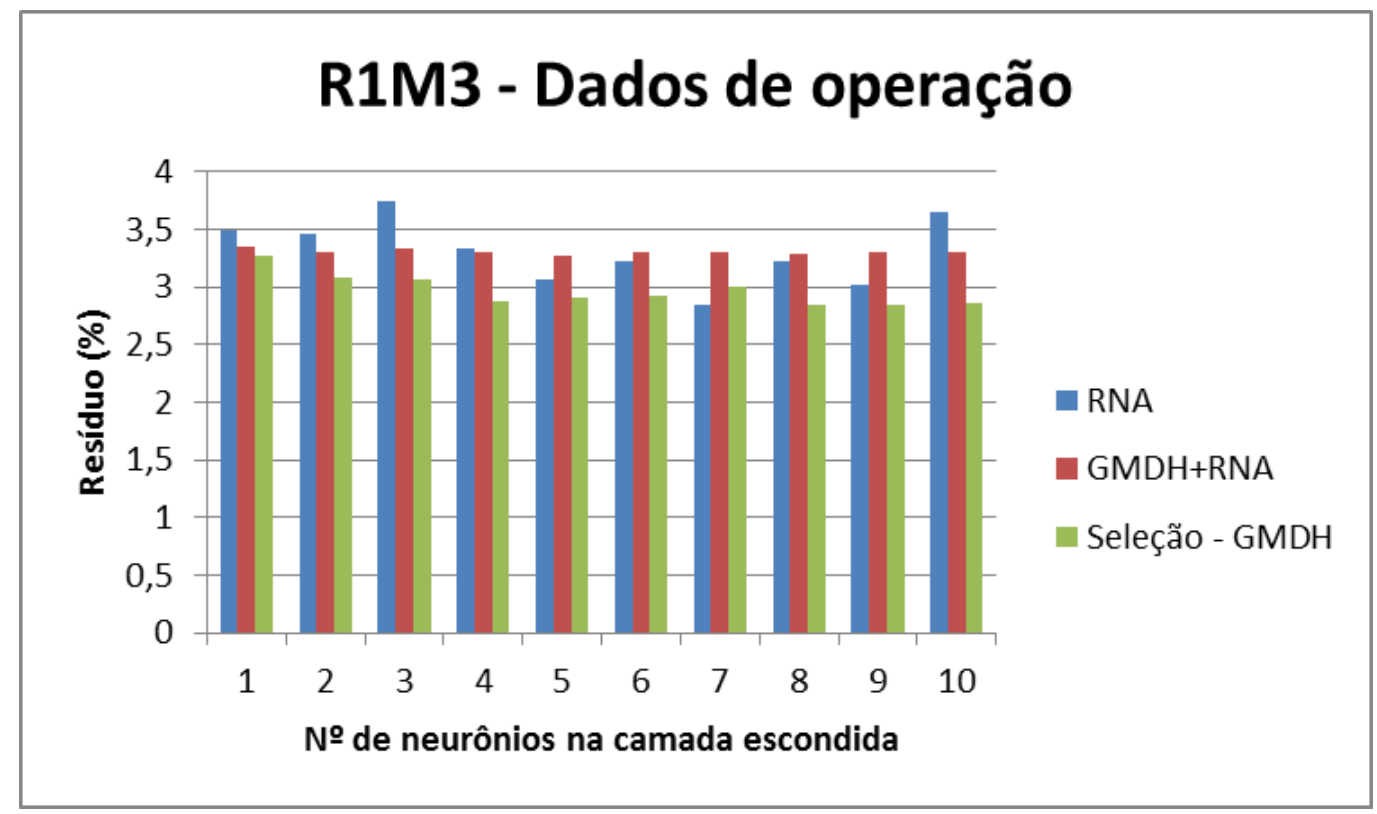

Figura 38. Monitoração de R1M3 - Comparação entre as metodologias

- Monitoração de R2M3

Ao realizar o pré-processamento através do estudo das variáveis desconsideradas pelo GMDH, verificou-se que para a variável R2M3(modelo 3), as variáveis que tiveram uma relevância maior para o GMDH foram: Z1, Z3, N2, R1M3, T3, T4 e T7. Essas variáveis foram utilizadas no treinamento das RNA, onde a rede com 9 neurônios na camada escondida apresentou o menor resíduo, cujo valor foi 2,3585 (Figura 39).

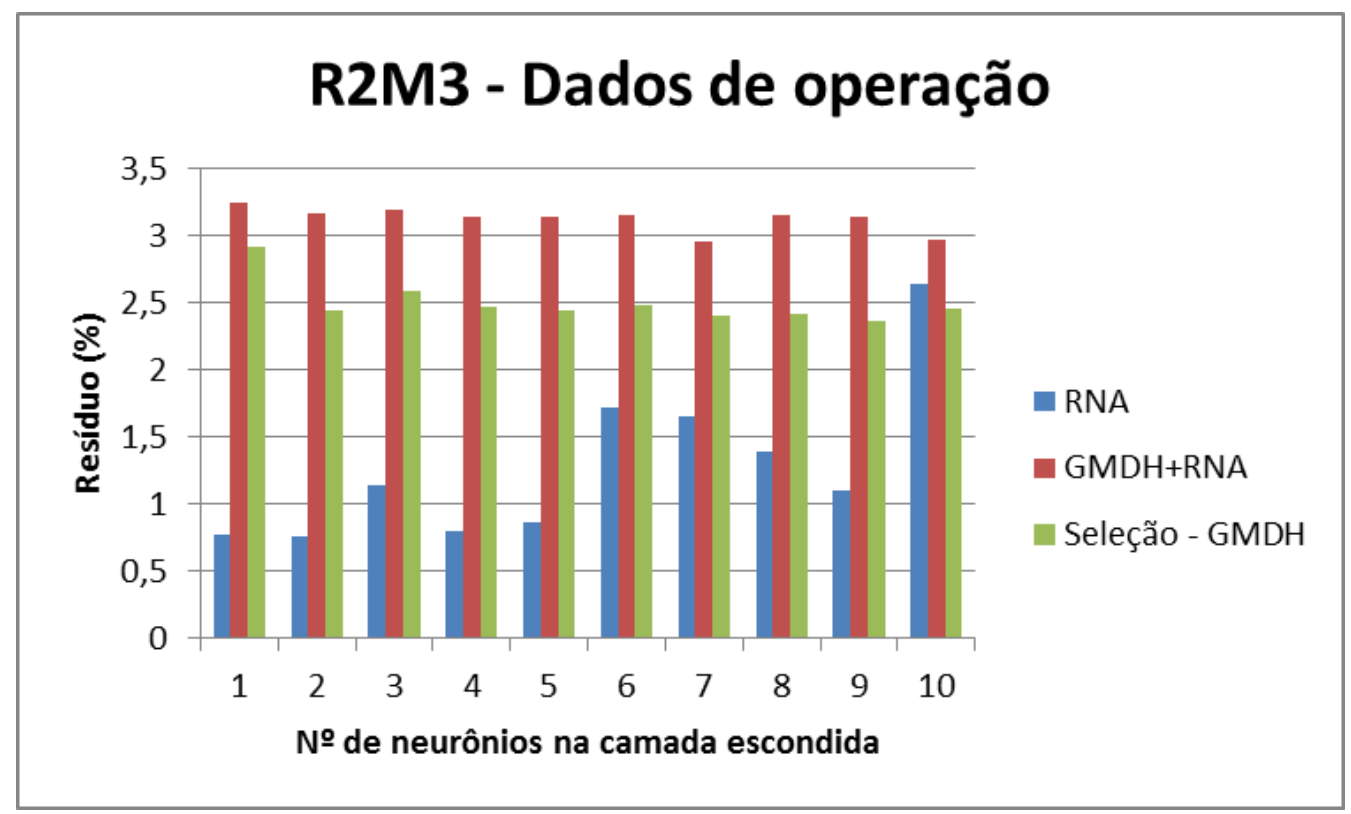

Figura 39. Monitoração de R2M3 - Comparação entre as metodologias 
Como pode ser observado na Figura acima, o uso de RNA apresentou os menores valores residuais, na maioria dos casos simulados.

\section{- Monitoração de Z1}

Ao realizar o pré-processamento através do estudo das variáveis desconsideradas pelo GMDH, verificou-se que para a variável Z1(modelo 3), as variáveis que tiveram uma relevância maior para o GMDH foram: Z2, Z3, F1M3, R1M3, e R2M3. Essas variáveis foram utilizadas no treinamento das RNA, onde a rede com 10 neurônios na camada escondida apresentou o menor resíduo, cujo valor foi 1,0880 (Figura 40).

Como pode ser observado na Figura a seguir, o uso de Seleção - GMDH apresentou os menores valores residuais, na maioria dos casos simulados.

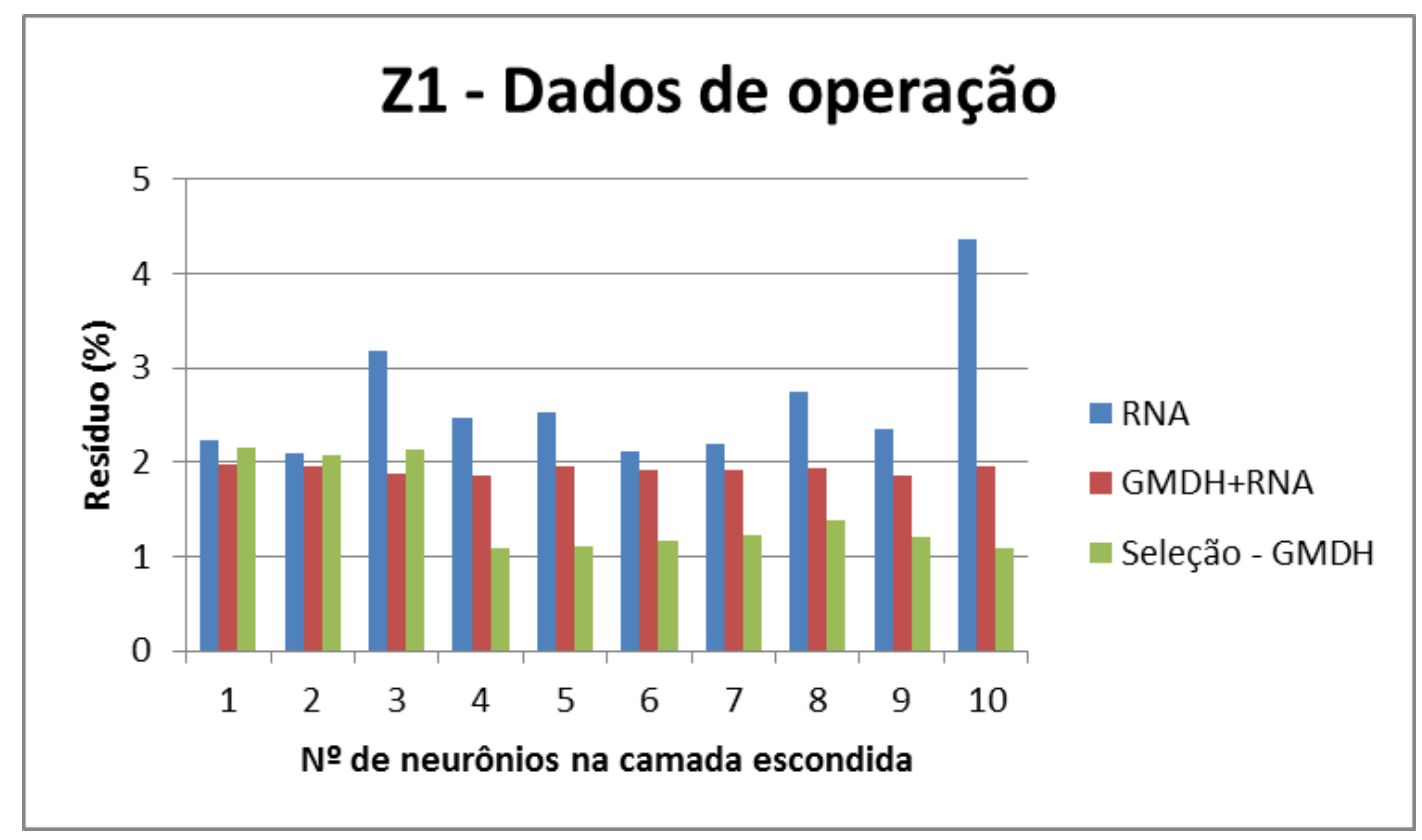

Figura 40. Monitoração de Z1 - Comparação entre as metodologias

\section{- Monitoração de Z2}

Ao realizar o pré-processamento através do estudo das variáveis desconsideradas pelo GMDH, verificou-se que para a variável Z2 (modelo 3), as variáveis que tiveram uma relevância maior para o GMDH foram: Z1, Z3, R1M3 e R2M3. Essas variáveis foram utilizadas no treinamento das RNA, onde a rede com 10 neurônios na camada escondida apresentou o menor resíduo, cujo valor foi 0,0834 (Figura 41).

Como pode ser observado na Figura a seguir, o uso de Seleção - GMDH apresentou os menores valores residuais, na maioria dos casos simulados. 


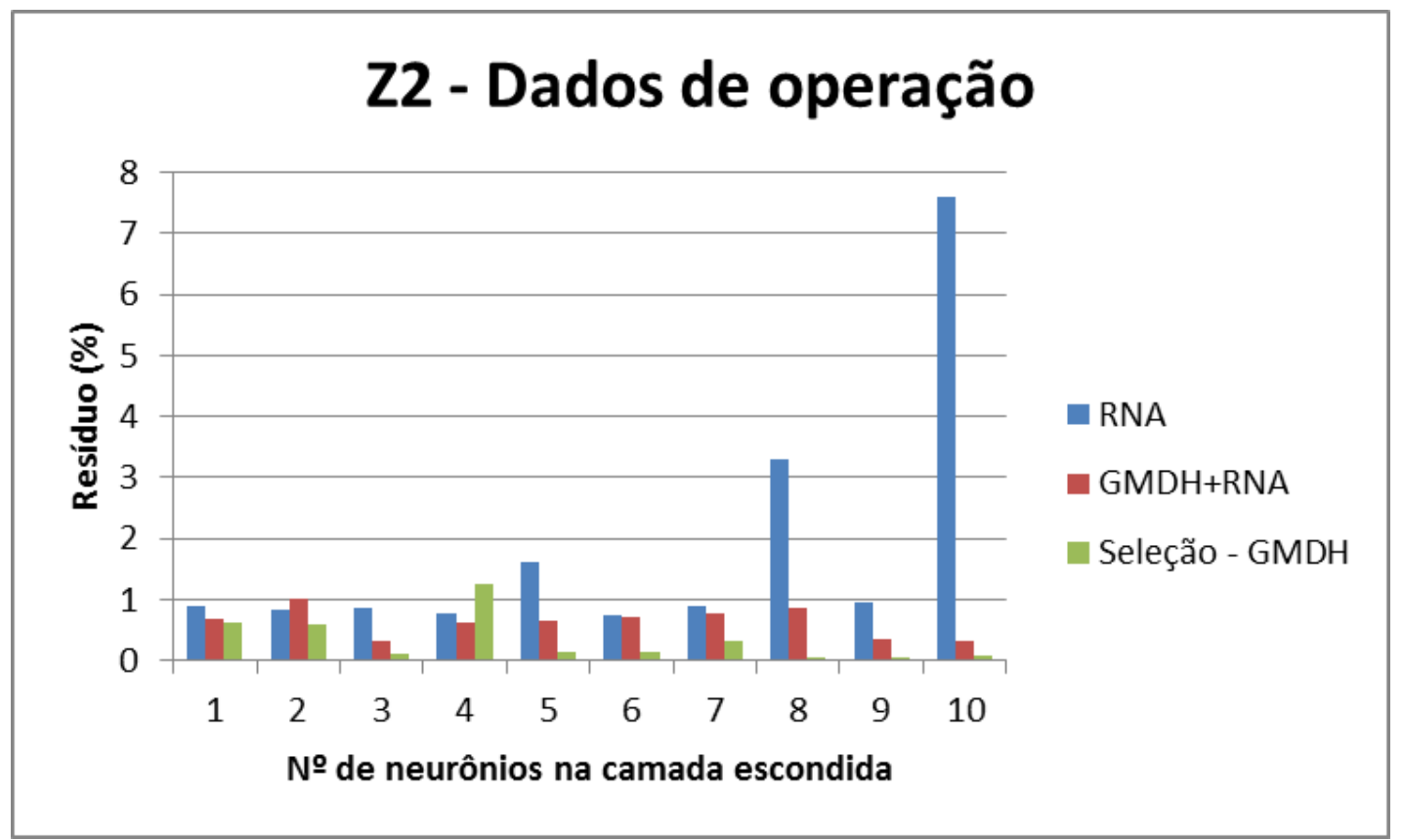

Figura 41. Monitoração de Z2 - Comparação entre as metodologias

- Monitoração de Z3

Ao realizar o pré-processamento através do estudo das variáveis desconsideradas pelo GMDH, verificou-se que para a variável Z3(modelo 3), as variáveis que tiveram uma relevância maior para o GMDH foram: Z1, Z2 e R2M3. Essas variáveis foram utilizadas no treinamento das RNA, onde a rede com 10 neurônios na camada escondida apresentou o menor resíduo, cujo valor foi 0,0314 (Figura 42).

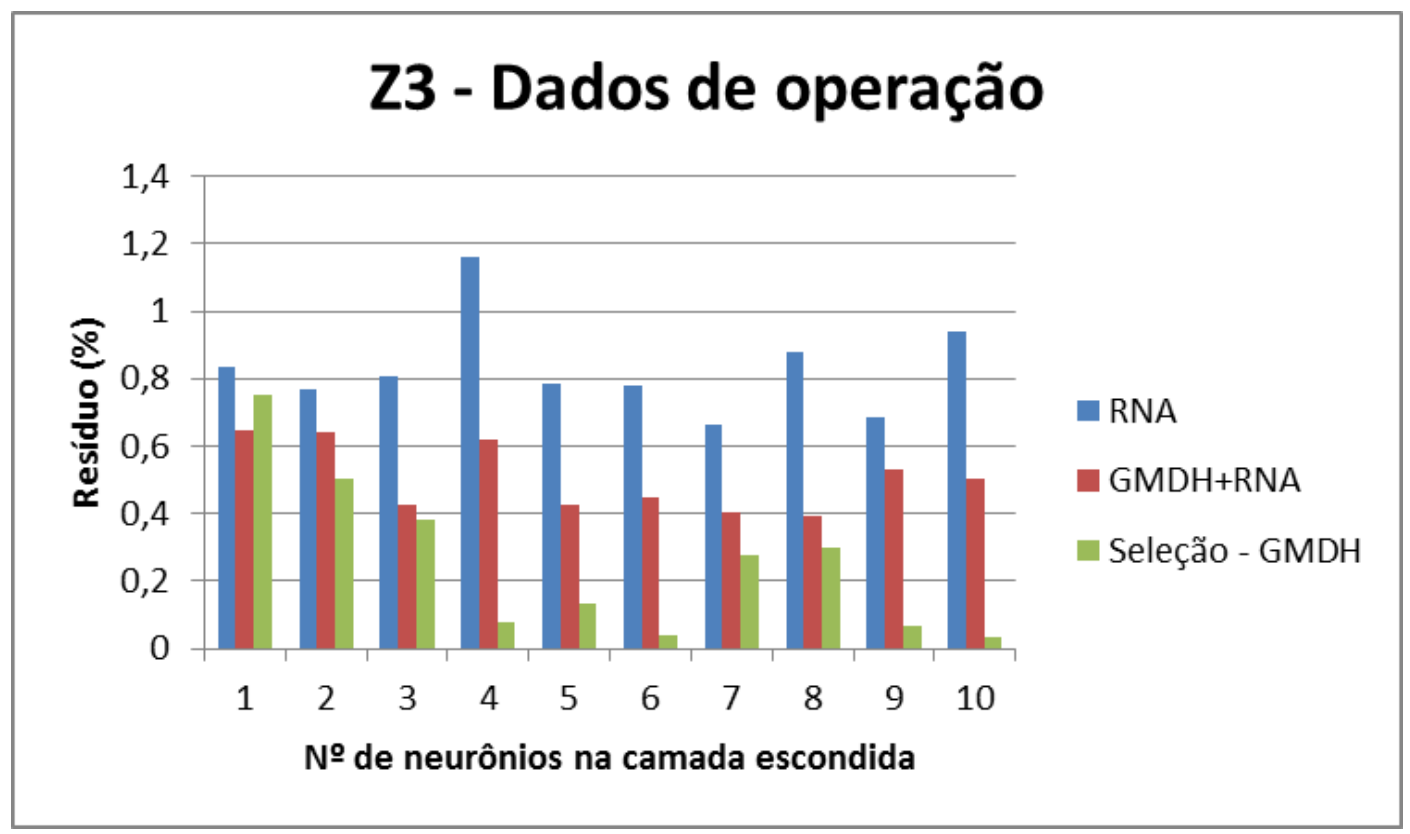

Figura 42. Monitoração de Z3 - Comparação entre as metodologias 
Como pode ser observado na Figura acima, o uso de Seleção - GMDH apresentou os menores valores residuais, na maioria dos casos simulados.

\subsubsection{Análise dos resultados obtidos}

Na Tabela 5 será apresentada uma síntese dos melhores resultados obtidos na monitoração das variáveis abrangidas pelo modelo 3 .

Tabela 5. Resultados obtidos na Monitoração - modelo 3

\begin{tabular}{|c|c|c|c|}
\hline \multirow{2}{*}{$\begin{array}{c}\text { Variável } \\
\text { monitorada }\end{array}$} & Seleção - GMDH & GMDH+RNA & RNA \\
\cline { 2 - 4 } T3 & $\mathbf{0 , 3 4 3 0}$ & 0,4941 & 0,8899 \\
\hline T4 & $\mathbf{0 , 2 5 5 3}$ & 0,3997 & 0,5073 \\
\hline T7 & $\mathbf{0 , 3 9 2 6}$ & 0,5018 & 0,5539 \\
\hline T8 & 1,1084 & 0,9631 & $\mathbf{0 , 2 0 1 1}$ \\
\hline T9 & 0,2982 & 0,5672 & $\mathbf{0 , 1 2 0 9}$ \\
\hline N2 & 0,5967 & $\mathbf{0 , 3 0 9 1}$ & 0,7442 \\
\hline F1M3 & --------- & --------- & ---------- \\
\hline F2M3 & ---------- & ---------- & ---------- \\
\hline R1M3 & $\mathbf{2 , 8 3 4 8}$ & 3,2730 & 3,0176 \\
\hline R2M3 & 2,3585 & 2,9707 & $\mathbf{0 , 7 5 2 3}$ \\
\hline Z1 & $\mathbf{1 , 0 8 8 0}$ & 1,8612 & 2,0929 \\
\hline Z2 & $\mathbf{0 , 0 4 7 2}$ & 0,3183 & 0,7441 \\
\hline Z3 & $\mathbf{0 , 0 3 1 4}$ & 0,4061 & 0,6618 \\
\hline
\end{tabular}

Através da análise desta tabela, verifica-se que:

Os resíduos obtidos na monitoração das variáveis T3, T4, T7, R1M3, Z1, Z2 e Z3 usando Seleção - GMDH foram menores do que os obtidos com GMDH+RNA e apenas RNA;

* Na monitoração da variável N2, o menor resíduo obtido foi através de GMDH+RNA;

- Na monitoração de T8, T9 e R2M3, o menor resíduo obtido foi utilizando apenas RNA. 
Através dos bons resultados obtidos, na maioria das situações, utilizando-se as variáveis com uma maior predominância na equação polinomial na etapa de préprocessamento, decidiu-se estender o estudo para os demais modelos. Para tanto, utilizouse o modelo 4, onde a informação da variável vazão não foi levada em consideração, permitindo assim investigar a influência desta variável para o modelo. Os resultados obtidos serão apresentados no próximo tópico.

\subsubsection{Modelo 4}

As variáveis abrangidas pelo modelo 4 são: Z1, Z2, Z3, N2, R1M3, R2M3, T3, T4, T7, T8 е T9.

Para a monitoração das variáveis do modelo 4, o procedimento foi o mesmo utilizado anteriormente, ou seja, foram treinadas 10 RNA, variando-se o número de neurônios na camada escondida de 1 a 10.. A camada de entrada foi alimentada das seguintes maneiras: por uma nova estimativa das variáveis de entrada (matriz_z) obtida através do algoritmo GMDH e pelas variáveis mais relevantes (RNA seleção). As Figuras 43 a 53 apresentam os resultados de monitoração do modelo 4.

- Monitoração da Potência (N2)

Ao realizar o pré-processamento através do estudo das variáveis desconsideradas pelo GMDH, verificou-se que para a variável N2(modelo 4), as variáveis que tiveram uma relevância maior para o GMDH foram: Z1, Z2, Z3 e T3. Essas variáveis foram utilizadas no treinamento das RNA, onde a rede com 9 neurônios na camada escondida apresentou o menor resíduo, cujo valor foi 0,2632 (Figura 43).

Como pode ser observado na Figura a seguir, a combinação dos métodos GMDH e RNA apresentou os menores valores residuais, na maioria dos casos simulados. 


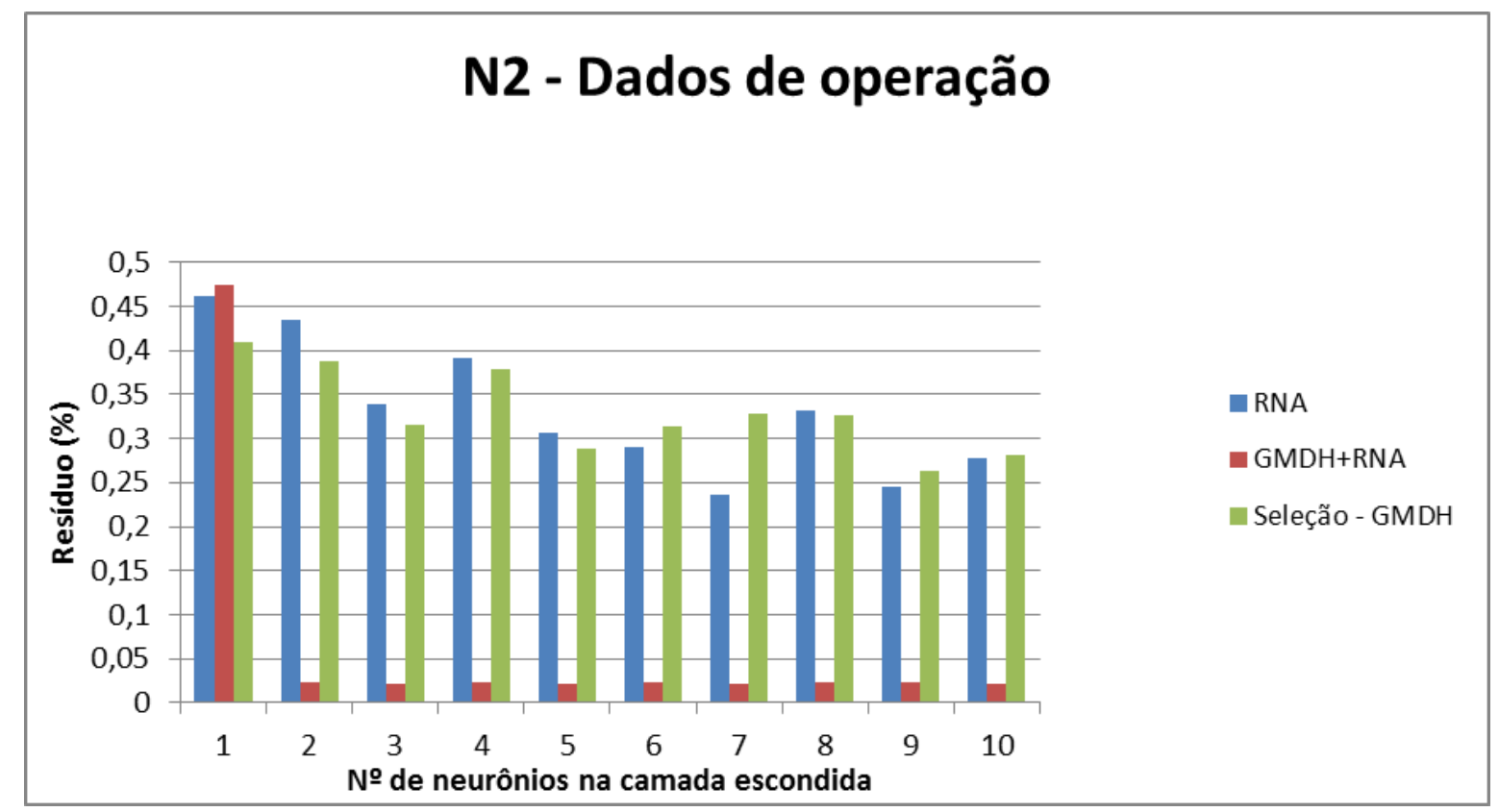

Figura 43. Monitoração de N2 - Comparação entre as metodologias

\section{- Monitoração de T3}

Ao realizar o pré-processamento através do estudo das variáveis desconsideradas pelo GMDH, verificou-se que para a variável T3 (modelo 4), as variáveis que tiveram uma relevância maior para o GMDH foram: Z1, Z3, T4 e T8. Essas variáveis foram utilizadas no treinamento das RNA, onde a rede com 5 neurônios na camada escondida apresentou o menor resíduo, cujo valor foi 0,2840 (Figura 44). Como pode ser observado na Figura a seguir, o uso de RNA apresentou os menores valores residuais.

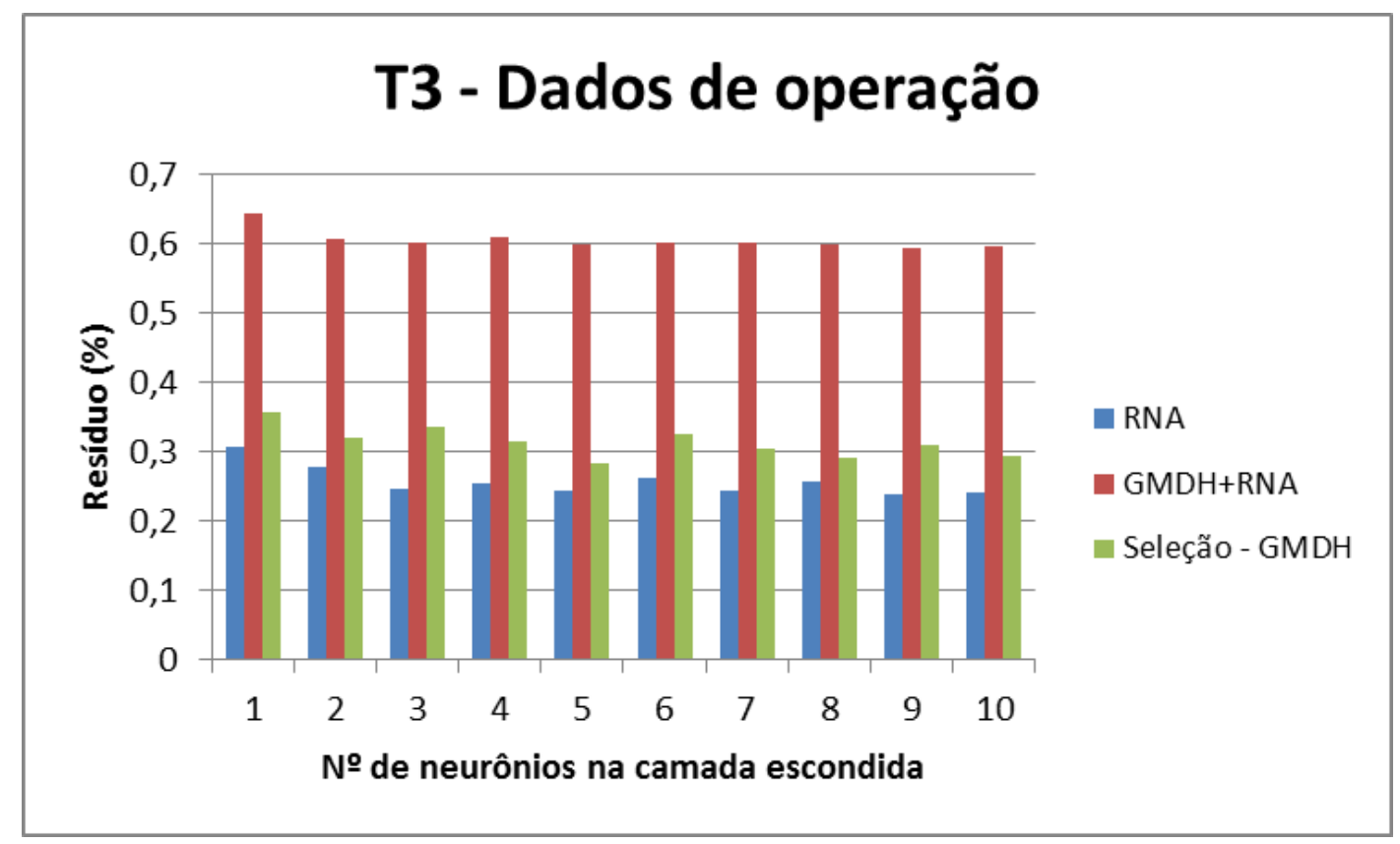

Figura 44. Monitoração de T3 - Comparação entre as metodologias 
- Monitoração de T4

Ao realizar o pré-processamento através do estudo das variáveis desconsideradas pelo GMDH, verificou-se que para a variável T4 (modelo 4), as variáveis que tiveram uma relevância maior para o GMDH foram: Z1, Z3, T3 e T8. Essas variáveis foram utilizadas no treinamento das RNA, onde a rede com 7 neurônios na camada escondida apresentou o menor resíduo, cujo valor foi 0,2447 (Figura 45).

Como pode ser observado na Figura a seguir, o uso de RNA apresentou os menores valores residuais, na maioria dos casos simulados.

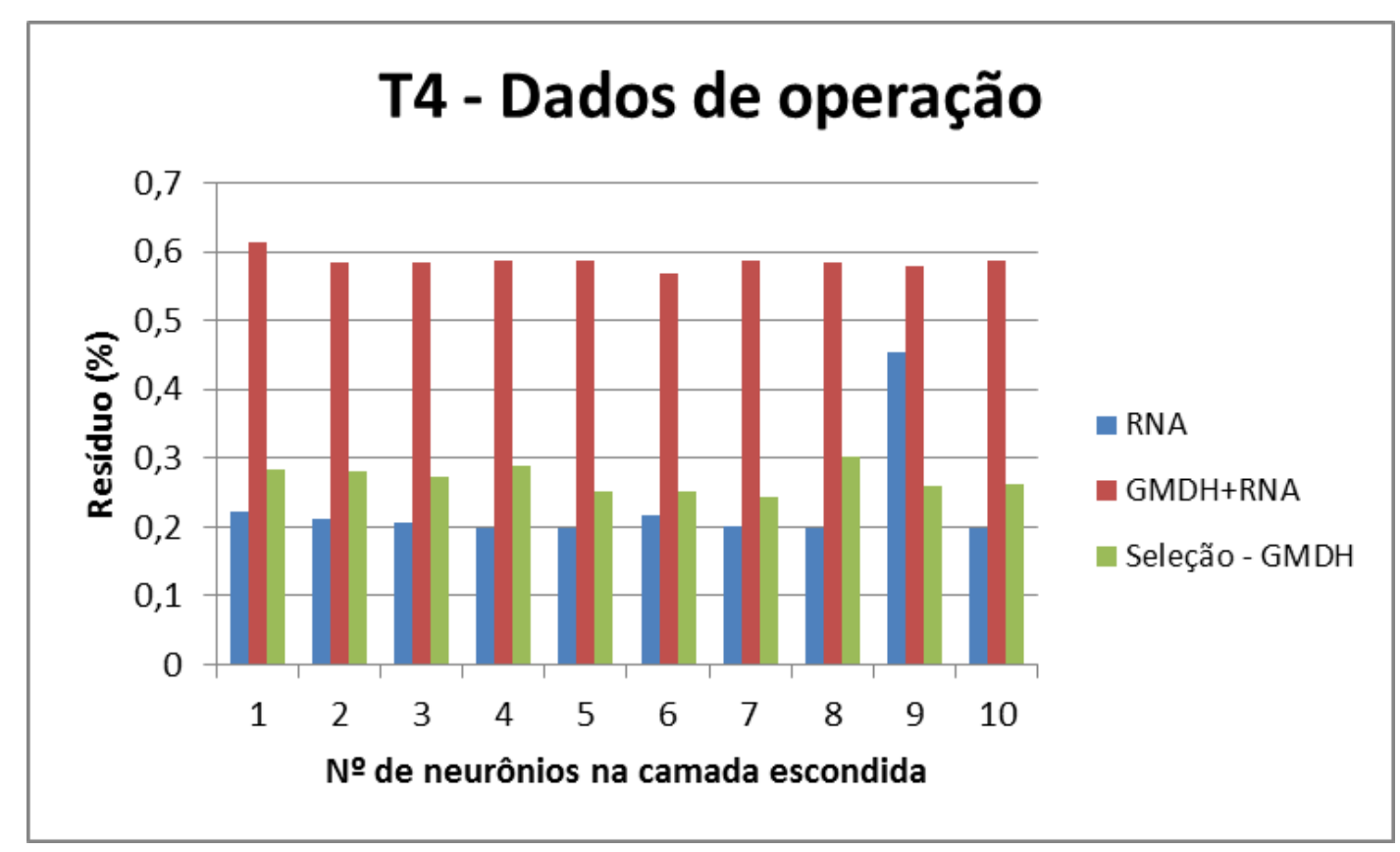

Figura 45. Monitoração de T4 - Comparação entre as metodologias

- Monitoração de T7

Ao realizar o pré-processamento através do estudo das variáveis desconsideradas pelo GMDH, verificou-se que para a variável T7 (modelo 4), as variáveis que tiveram uma relevância maior para o GMDH foram: Z1, Z2, Z3, T8 e T9. Essas variáveis foram utilizadas no treinamento das RNA, onde a rede com 10 neurônios na camada escondida apresentou o menor resíduo, cujo valor foi 0,3703 (Figura 46).

Como pode ser observado na Figura a seguir, o uso de RNA apresentou os menores valores residuais. 


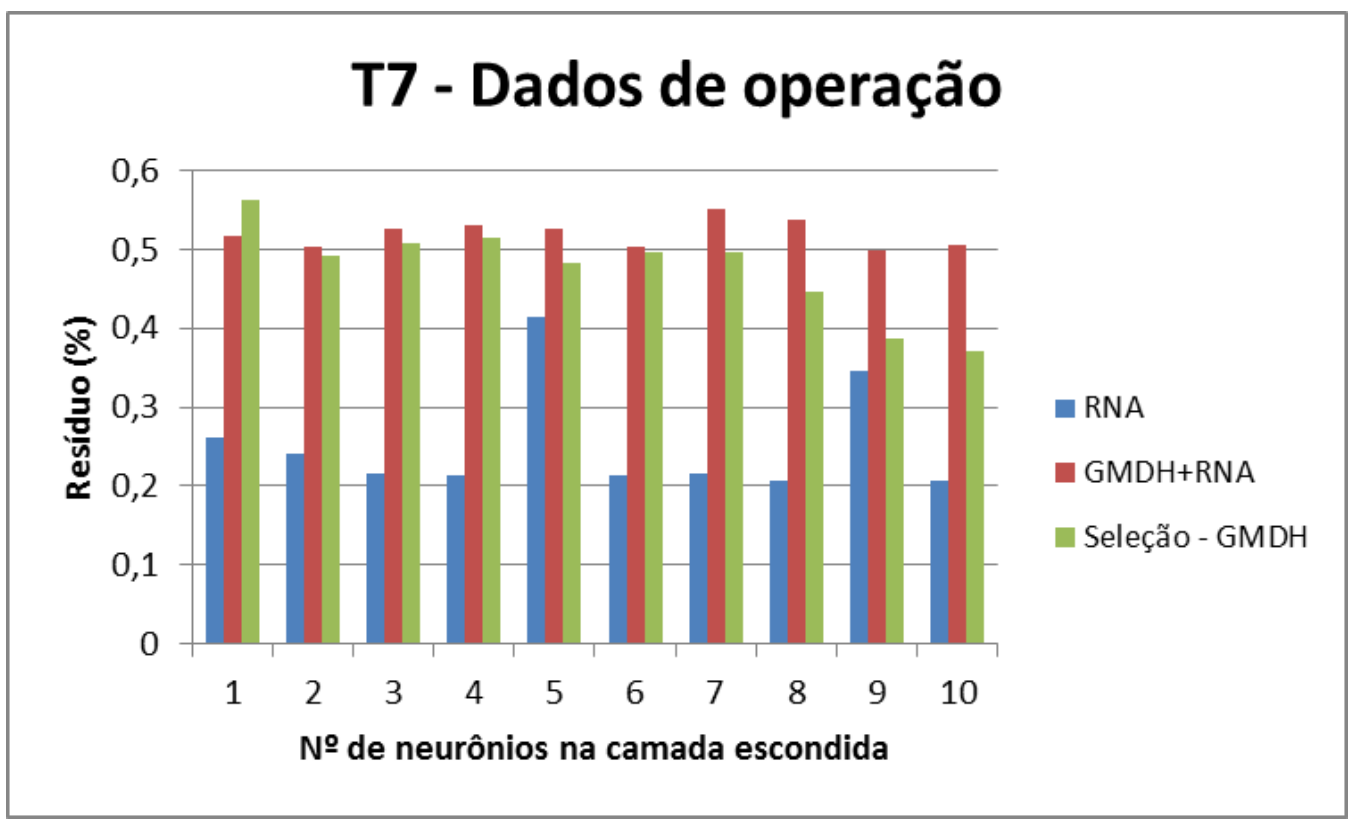

Figura 46. Monitoração de T7 - Comparação entre as metodologias

\section{- Monitoração de T8}

Ao realizar o pré-processamento através do estudo das variáveis desconsideradas pelo GMDH, verificou-se que para a variável T8 (modelo 4), as variáveis que tiveram uma relevância maior para o GMDH foram: Z1, Z2, Z3, N2, T7 e T9. Essas variáveis foram utilizadas no treinamento das RNA, onde a rede com 9 neurônios na camada escondida apresentou o menor resíduo, cujo valor foi 0,5855 (Figura 47).

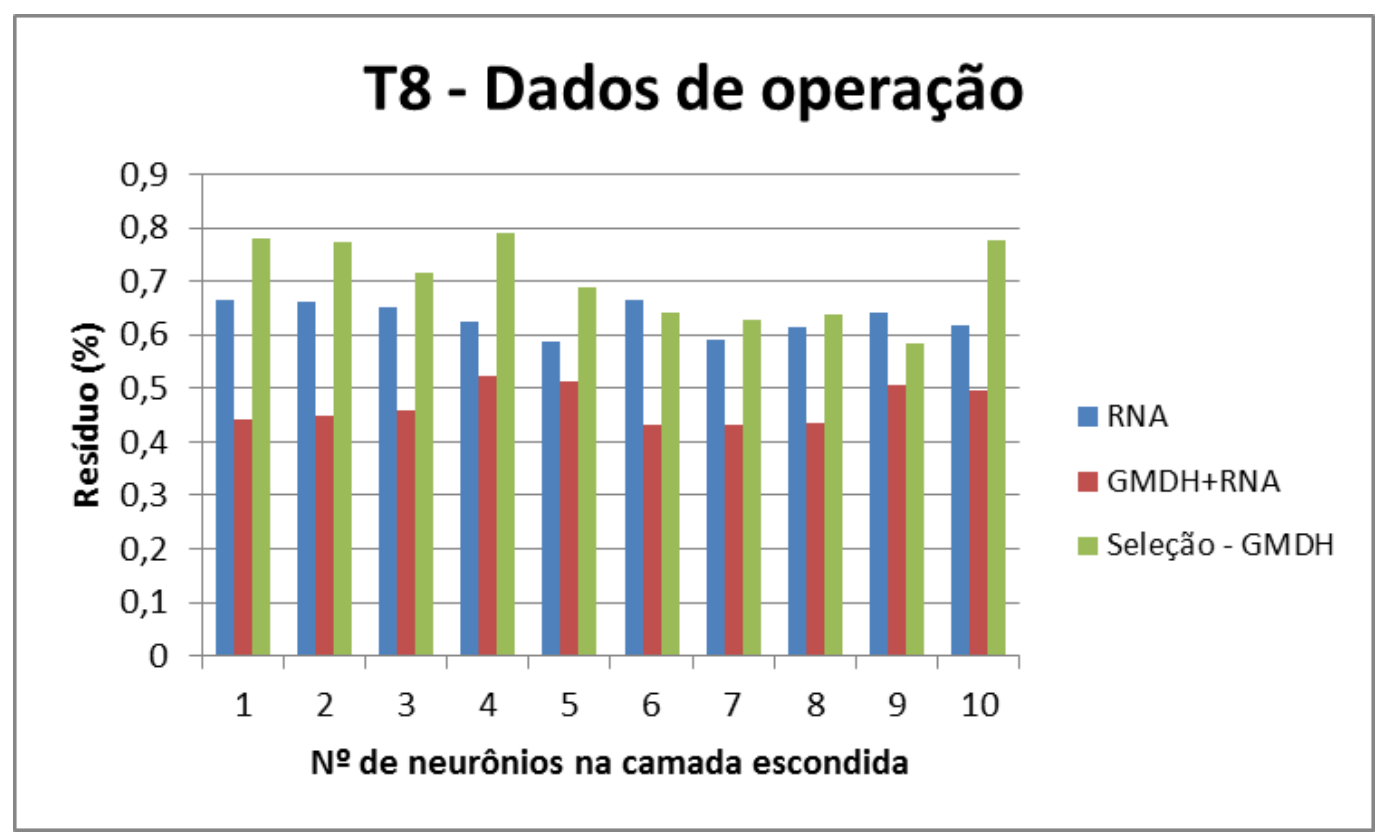

Figura 47. Monitoração de T8 - Comparação entre as metodologias 
Como pode ser observado na Figura acima, a combinação dos métodos GMDH e RNA apresentou os menores valores residuais.

\section{- Monitoração de T9}

Ao realizar o pré-processamento através do estudo das variáveis desconsideradas pelo GMDH, verificou-se que para a variável T9 (modelo 4), as variáveis que tiveram uma relevância maior para o GMDH foram: Z1, T7 e T8. Essas variáveis foram utilizadas no treinamento das RNA, onde a rede com 10 neurônios na camada escondida apresentou o menor resíduo, cujo valor foi 0,3152 (Figura 48).

Como pode ser observado na Figura a seguir, o uso de RNA apresentou os menores valores residuais.

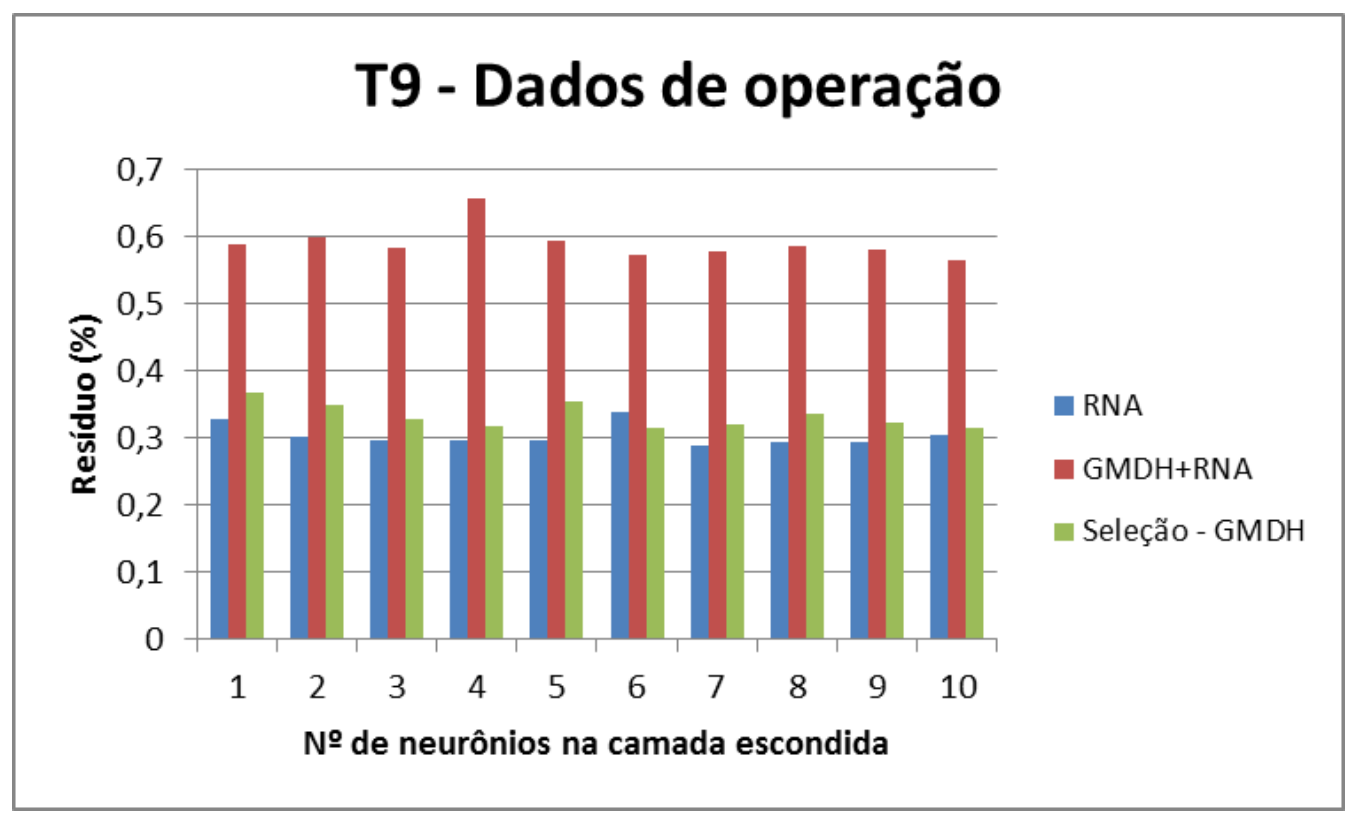

Figura 48. Monitoração de T9 - Comparação entre as metodologias

\section{- Monitoração de RlM3}

Ao realizar o pré-processamento através do estudo das variáveis desconsideradas pelo GMDH, verificou-se que para a variável R1M3 (modelo 4), as variáveis que tiveram uma relevância maior para o GMDH foram: Z1, Z2, Z3, N2 e T8. Essas variáveis foram utilizadas no treinamento das RNA, onde a rede com 7 neurônios na camada escondida apresentou o menor resíduo, cujo valor foi 2,8214 (Figura 49).

Como pode ser observado na Figura a seguir, a combinação dos métodos GMDH e RNA apresentou os menores valores residuais. 


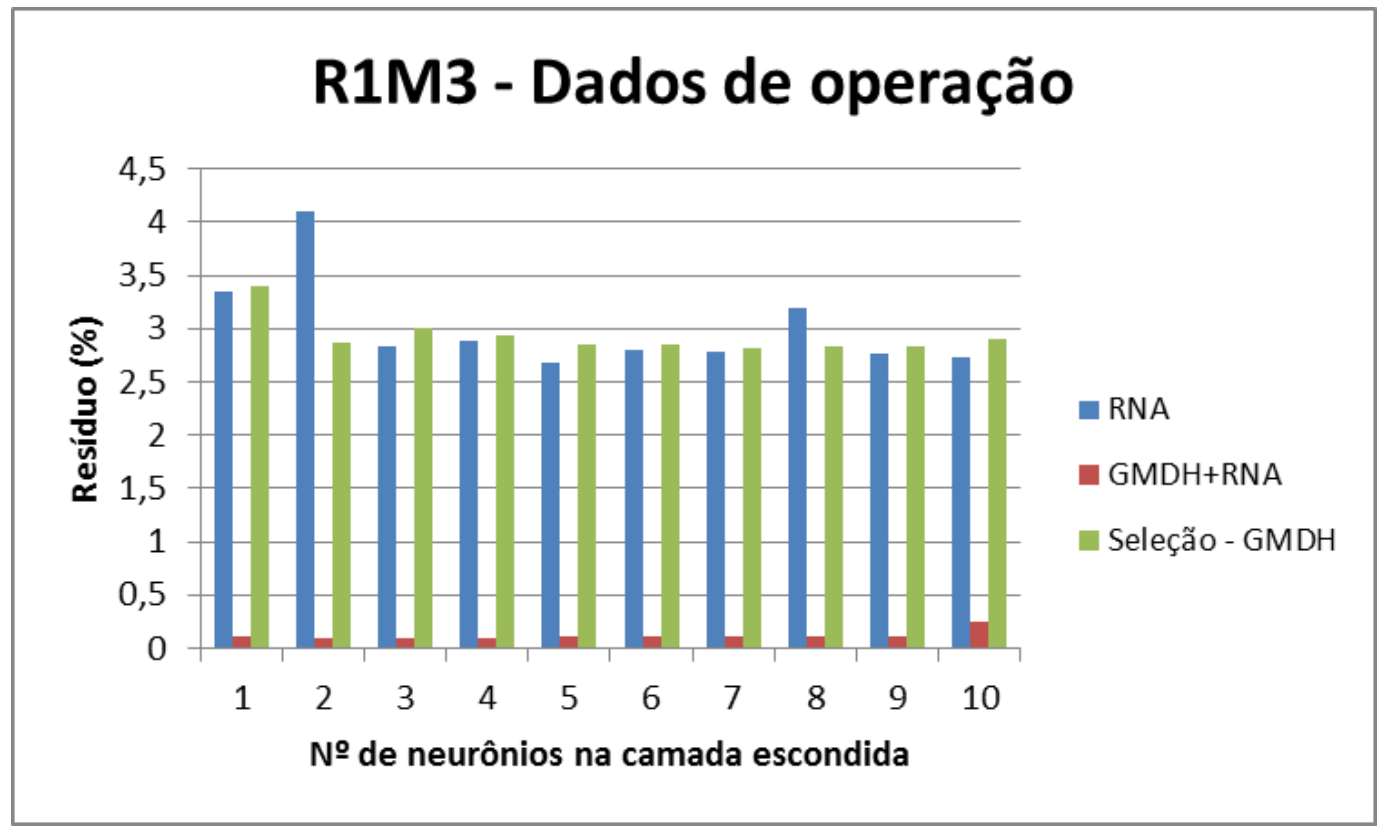

Figura 49. Monitoração de R1M3 - Comparação entre as metodologias

- Monitoração de R2M3

Ao realizar o pré-processamento através do estudo das variáveis desconsideradas pelo GMDH, verificou-se que para a variável R2M3 (modelo 4), as variáveis que tiveram uma relevância maior para o GMDH foram: Z1 e Z3. Essas redes foram utilizadas no treinamento das RNA, onde a rede com 9 neurônios na camada escondida apresentou o menor resíduo, cujo valor foi 2,3865 (Figura 50).

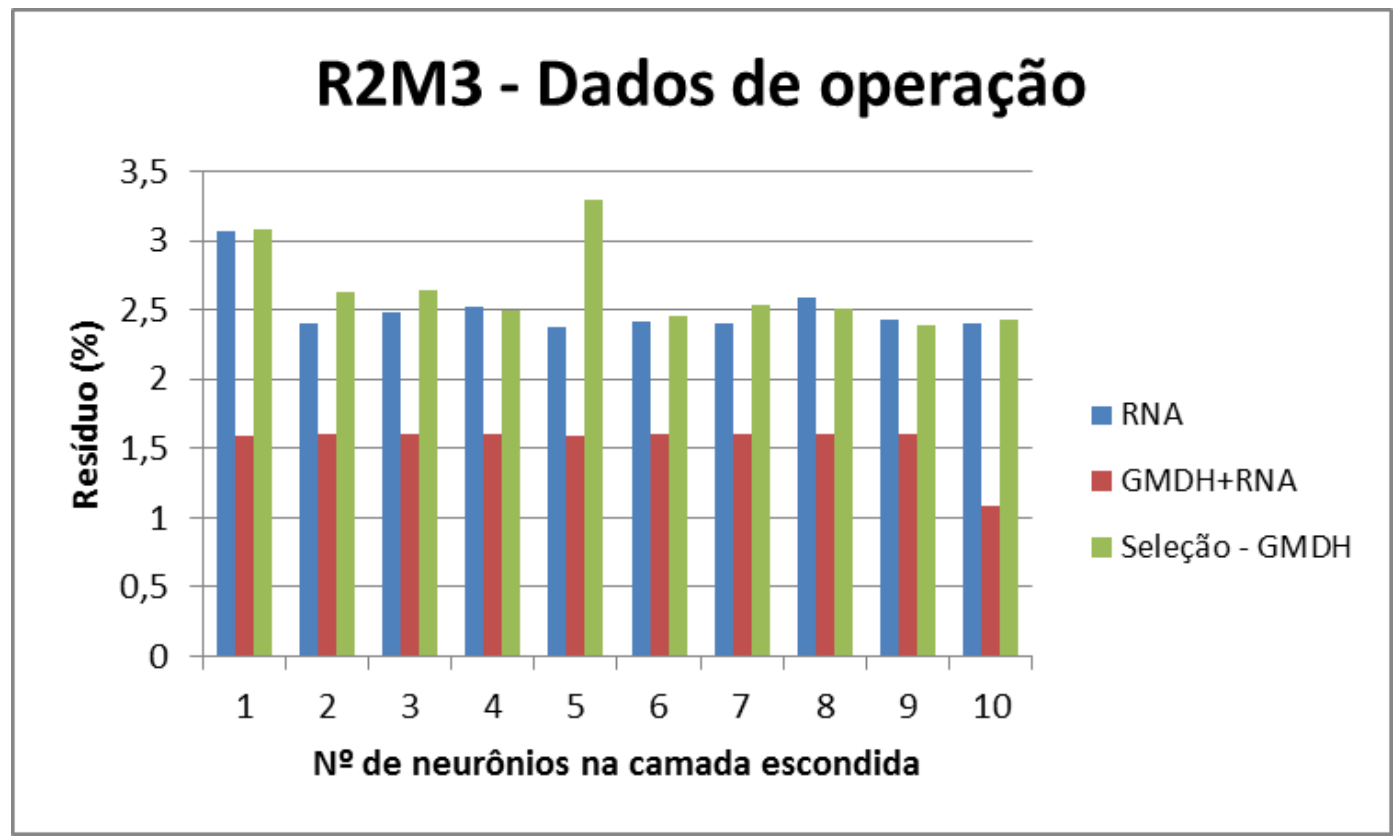

Figura 50. Monitoração de R2M3 - Comparação entre as metodologias 
Como pode ser observado na Figura acima, a combinação dos métodos GMDH e RNA apresentou os menores valores residuais.

\section{- Monitoração de Z1}

Ao realizar o pré-processamento através do estudo das variáveis desconsideradas pelo GMDH, verificou-se que para a variável Z1 (modelo 4), as variáveis que tiveram uma relevância maior para o GMDH foram: Z2, Z3 e T9. Essas variáveis foram utilizadas no treinamento das RNA, onde a rede com 8 neurônios na camada escondida apresentou o menor resíduo, cujo valor foi 2,1988 (Figura 51).

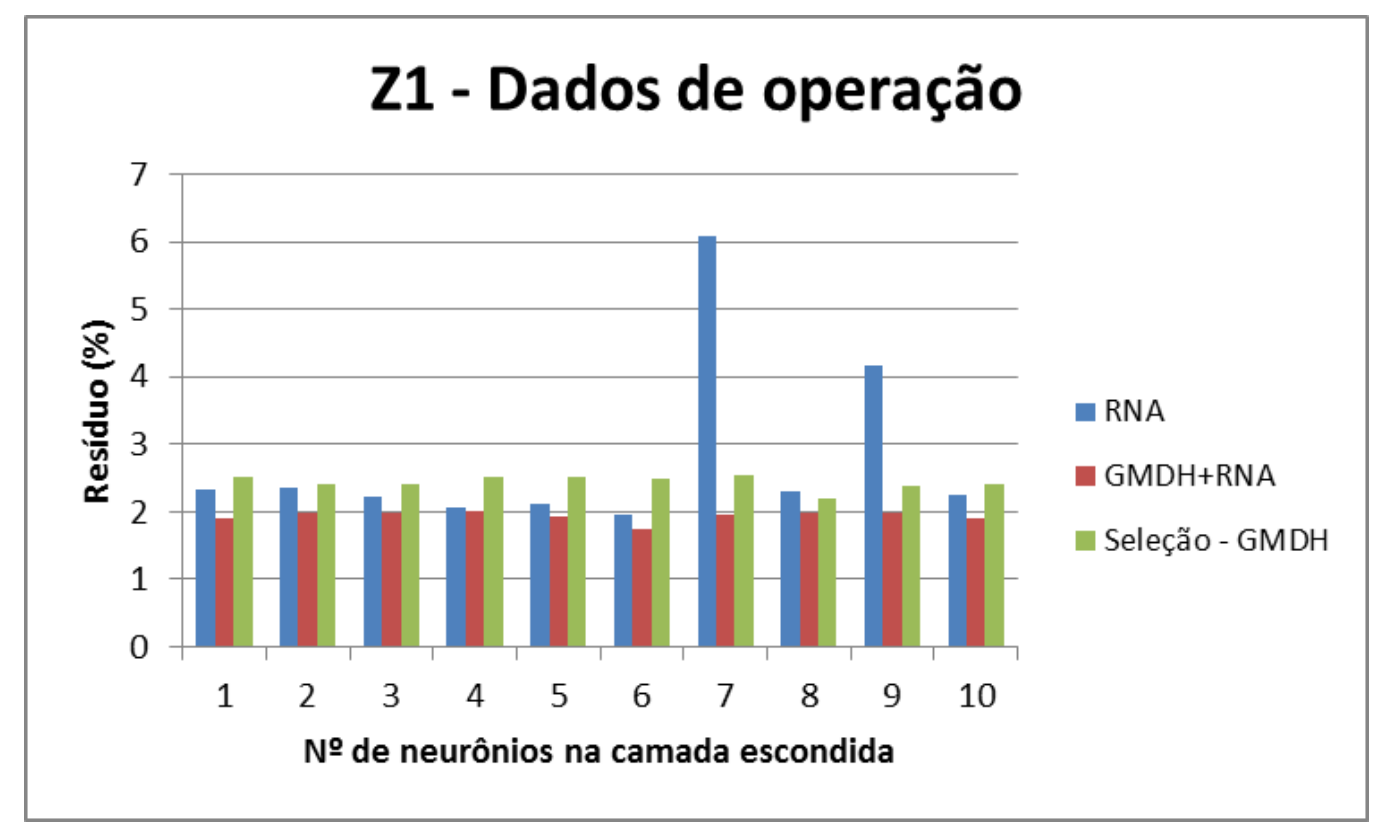

Figura 51. Monitoração de Z1 - Comparação entre as metodologias

Como pode ser observado na Figura acima, os menores valores residuais obtidos foram através do uso de GMDH + RNA.

\section{- Monitoração de Z2}

Ao realizar o pré-processamento através do estudo das variáveis desconsideradas pelo GMDH, verificou-se que para a variável Z2 (modelo 4), as variáveis que tiveram uma relevância maior para o GMDH foram: Z1, Z3, T3 e T4. Essas variáveis foram utilizadas no treinamento das RNA, onde a rede com 8 neurônios na camada escondida apresentou o menor resíduo, cujo valor foi 0,0474 (Figura 52). Como pode ser 
observado na Figura a seguir, os menores valores residuais obtidos foram através do uso de Seleção - GMDH.

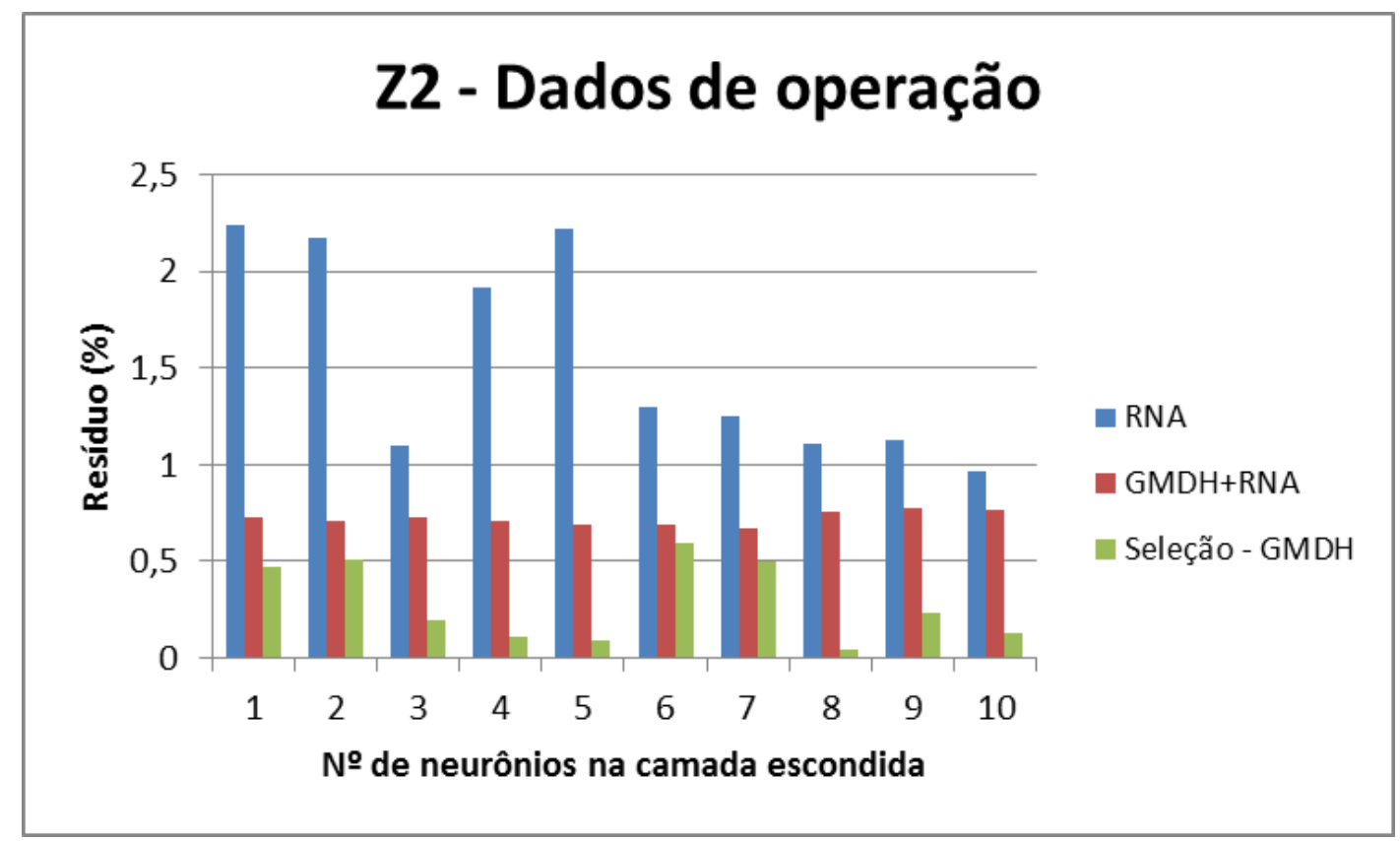

Figura 52. Monitoração de Z2 - Comparação entre as metodologias

- Monitoração de Z3

Ao realizar o pré-processamento através do estudo das variáveis desconsideradas pelo GMDH, verificou-se que para a variável Z3 (modelo 4), as variáveis que tiveram uma relevância maior para o GMDH foram: Z1, Z2 e R1M3. Essas variáveis foram utilizadas no treinamento das RNA, onde a rede com 10 neurônios na camada escondida apresentou o menor resíduo, cujo valor foi 0,1618 (Figura 53). 


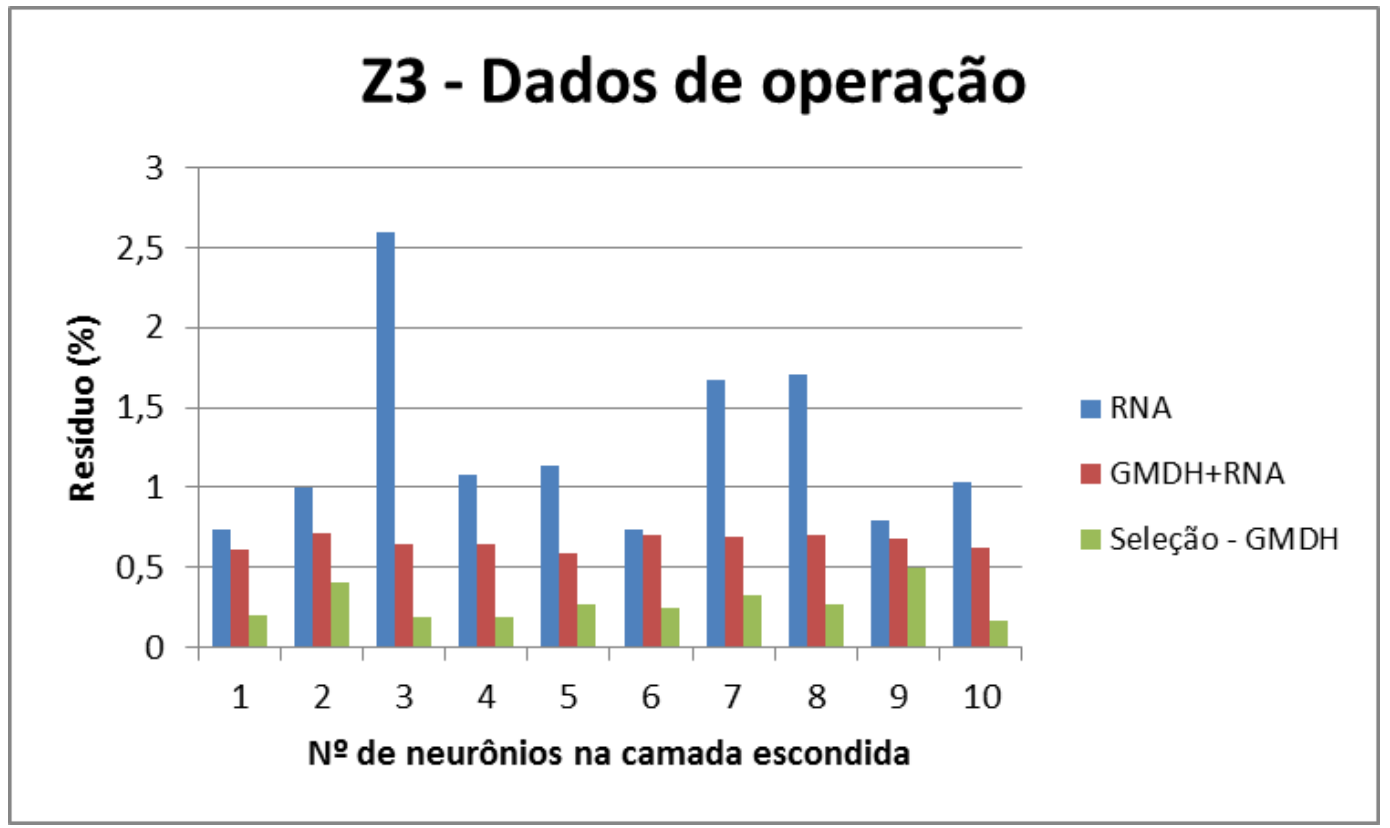

Figura 53. Monitoração de Z3 - Comparação entre as metodologias

Como pode ser observado na Figura acima, os menores valores residuais obtidos foram através do uso de Seleção - GMDH.

\subsubsection{Análise dos resultados obtidos}

Na Tabela 6 será apresentada uma síntese dos melhores resultados obtidos na monitoração das variáveis abrangidas pelo modelo 4 .

Tabela 6. Resultados obtidos Monitoração - modelo 4

\begin{tabular}{|l|l|l|l|}
\hline \multirow{2}{*}{ Variável monitorada } & \multicolumn{3}{|c|}{ Resíduo (\%) } \\
\cline { 2 - 4 } & Seleção - GMDH & GMDH+RNA & RNA \\
\hline T3 & 0,2840 & 0,5938 & $\mathbf{0 , 2 3 9 5}$ \\
\hline T4 & 0,2447 & 0,5799 & $\mathbf{0 , 1 9 8 2}$ \\
\hline T7 & 0,3703 & 0,4988 & $\mathbf{0 , 2 0 6 1}$ \\
\hline T8 & 0,5855 & $\mathbf{0 , 4 3 0 6}$ & 0,5875 \\
\hline T9 & 0,3152 & 0,5647 & $\mathbf{0 , 2 9 2 8}$ \\
\hline N2 & 0,2632 & 0,0213 & $\mathbf{0 , 2 4 5 0}$ \\
\hline R1M3 & 2,8214 & $\mathbf{0 , 1 0 0 5}$ & 2,7336 \\
\hline R2M3 & 2,3865 & $\mathbf{1 , 0 8 8 5}$ & 2,3786 \\
\hline Z1 & 2,1988 & $\mathbf{1 , 7 3 6 3}$ & 1,9527 \\
\hline
\end{tabular}




\begin{tabular}{|l|l|l|l|}
\hline \multirow{2}{*}{ Variável monitorada } & \multicolumn{3}{|c|}{ Resíduo (\%) } \\
\cline { 2 - 4 } & Seleção - GMDH & GMDH+RNA & RNA \\
\hline Z2 & $\mathbf{0 , 0 4 7 4}$ & 0,6746 & 1,0999 \\
\hline Z3 & $\mathbf{0 , 1 6 1 8}$ & 0,5908 & 0,7325 \\
\hline
\end{tabular}

Através da análise da tabela acima, verifica-se que:

* Os resíduos obtidos na monitoração das variáveis T3, T4, T7 e T9 usando apenas RNA foram menores do que os obtidos com os outros métodos. Este resultado mostra a importância da variável vazão para a monitoração destas variáveis;

* Para a monitoração das variáveis T8, R1M3, R2M3 e Z1, os resíduos obtidos através de GMDH + RNA foram menores do que os obtidos com os outros métodos;

* Para a monitoração de Z2 e Z3, os resíduos obtidos através de Seleção GMDH foram menores do que os obtidos com os outros métodos.

Para finalizar essa primeira etapa de estudos, decidiu-se investigar a utilização de Seleção - GMDH no quinto modelo, pois abrange as variáveis mais importantes durante a operação do reator IEA-R1. Os resultados serão apresentados no próximo tópico.

\subsubsection{Modelo 5}

As variáveis abrangidas pelo modelo 5 são: Z1, Z2, Z3, Z4, N1, N2, N3, N4, N5, N6, N7, N8, C1, C2, F1M3, F2M3, R1M3, R2M3, R3M3, R4M3, R5M3, R6M3, R7M3, R8M3, R9M3, R10M3, R11M3, R12M3, R13M3, R14M3, T1, T2, T3, T4, T6, T7, T8 e T9.

Para a monitoração das variáveis do modelo 5, o procedimento foi o mesmo utilizado anteriormente, ou seja, foram treinadas 10 RNA, variando-se o número de neurônios na camada escondida de 1 a 10. A camada de entrada foi alimentada das seguintes maneiras: por uma nova estimativa das variáveis de entrada (matriz_z) obtida através do algoritmo GMDH e pelas variáveis mais relevantes (RNA seleção). As Figuras 54 a 113 apresentam os resultados de monitoração para as variáveis do Modelo 5. Além disso, são apresentadas as comparações entre o valor lido da variável, e o valor estimado pelo Sistema de Monitoração e Diagnóstico, ou seja, saída da RNA comparada com a saída desejada, utilizando a etapa de pré-processamento - Seleção - GMDH. 
- Potência (N2)

Ao realizar o pré-processamento através do estudo das variáveis desconsideradas pelo GMDH, verificou-se que para a variável N2 (modelo 5), as variáveis que tiveram uma relevância maior para o GMDH foram: Z1 e N7. Essas variáveis foram utilizadas no treinamento das RNA, onde a rede com 8 neurônios na camada escondida apresentou o menor resíduo, cujo valor foi 0,1413 (Figura 54). A Figura 55 mostra a saída da rede em função da saída desejada com 8 neurônios na camada escondida.

Como pode ser observado na Figura a seguir, o uso de Seleção - GMDH apresentou os menores valores residuais.

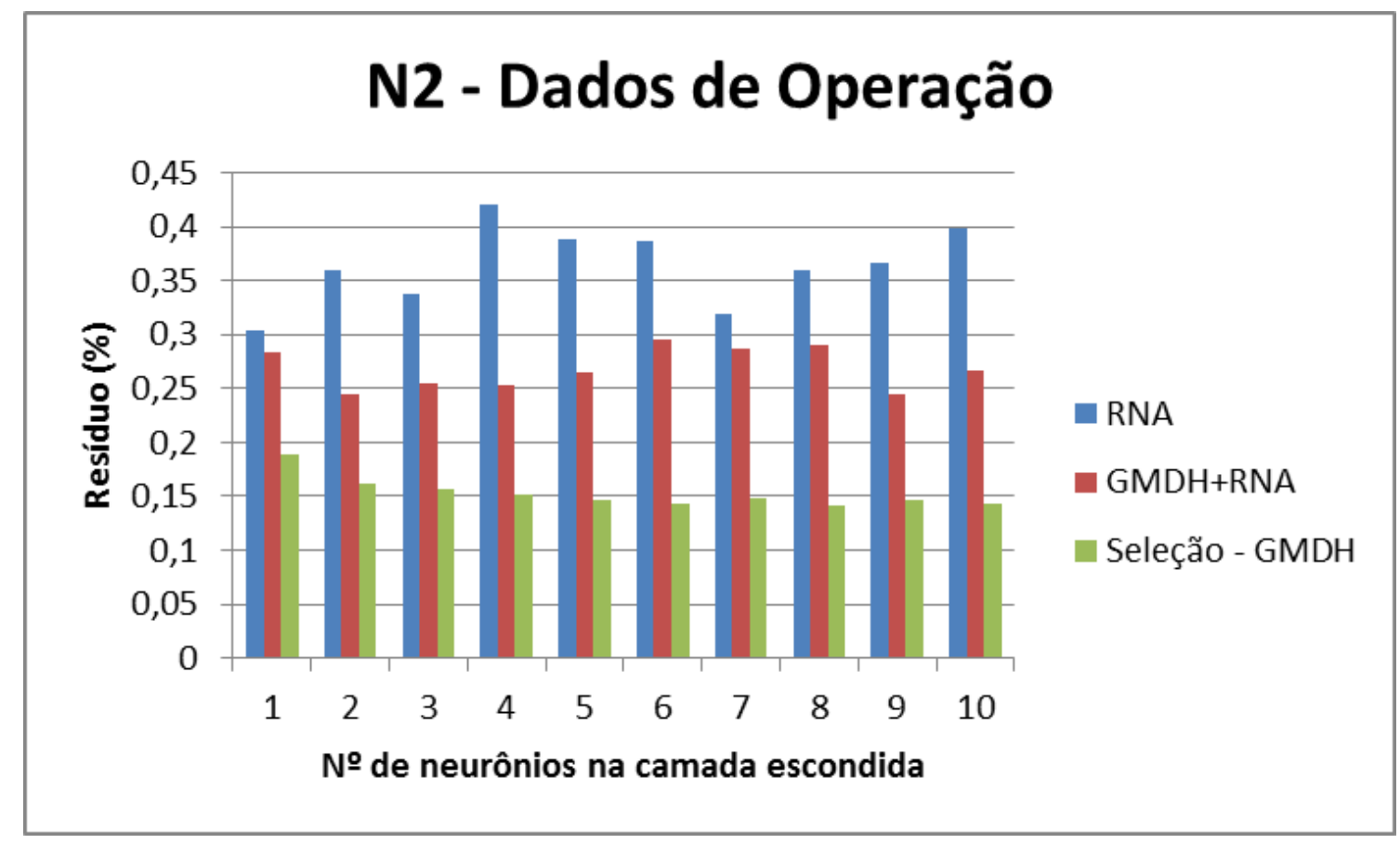

Figura 54. Monitoração de N2 - Comparação entre as metodologias 


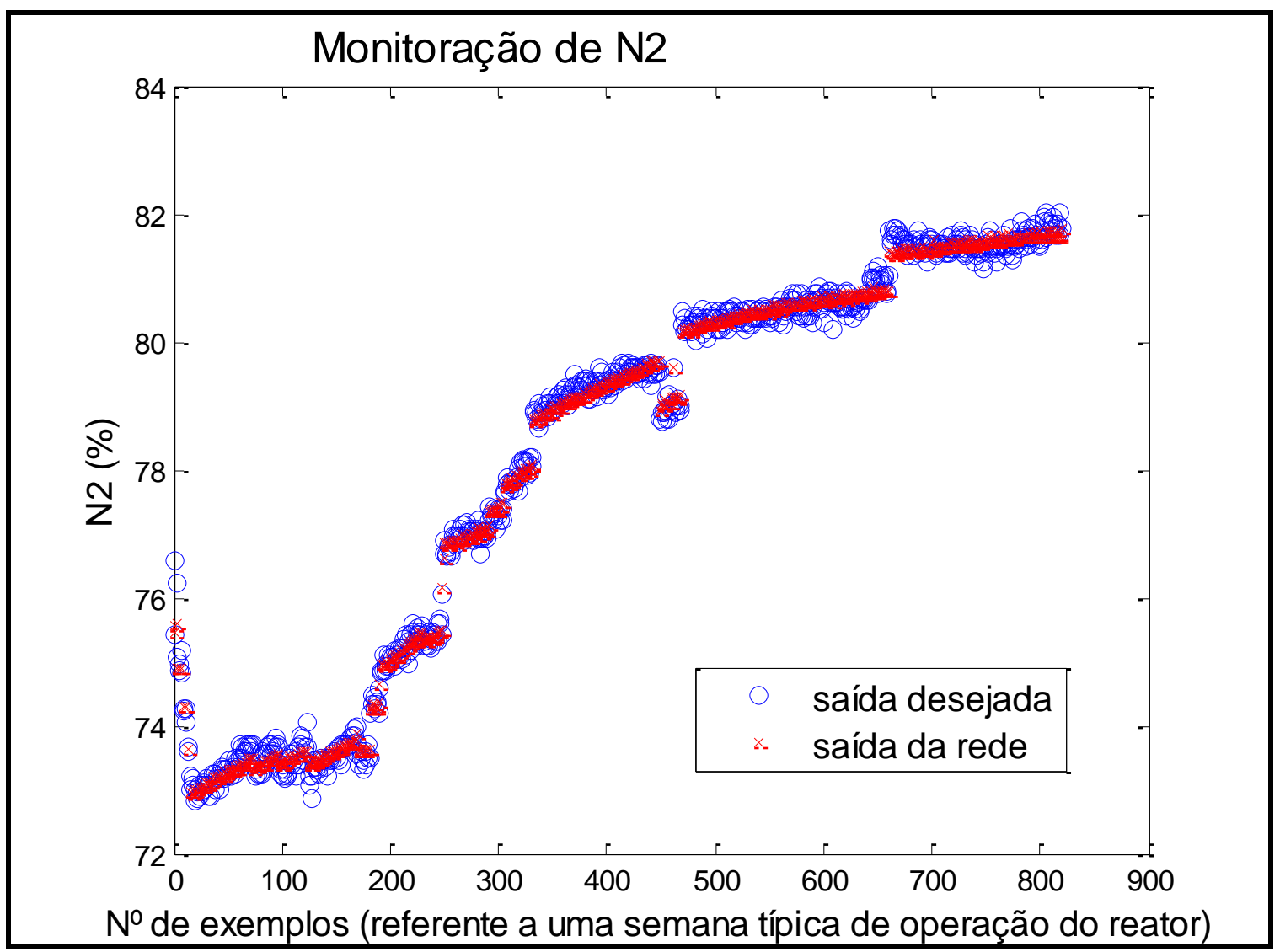

Figura 55.Saída desejada comparada à saída da rede com 8 neurônios na camada escondida

\section{- Monitoração de N3}

Ao realizar o pré-processamento através do estudo das variáveis desconsideradas pelo GMDH, verificou-se que para a variável N3 (modelo 5), as variáveis que tiveram uma relevância maior para o GMDH foram: N2, R8M3 e T1. Essas variáveis foram utilizadas no treinamento das RNA, onde a rede com 8 neurônios na camada escondida apresentou o menor resíduo, cujo valor foi 0,1642 (Figura 56). A Figura 57 mostra a saída da rede em função da saída desejada com 8 neurônios na camada escondida.

Como pode ser observado na Figura a seguir, o uso de Seleção - GMDH apresentou os menores valores residuais, na maioria dos casos simulados. 


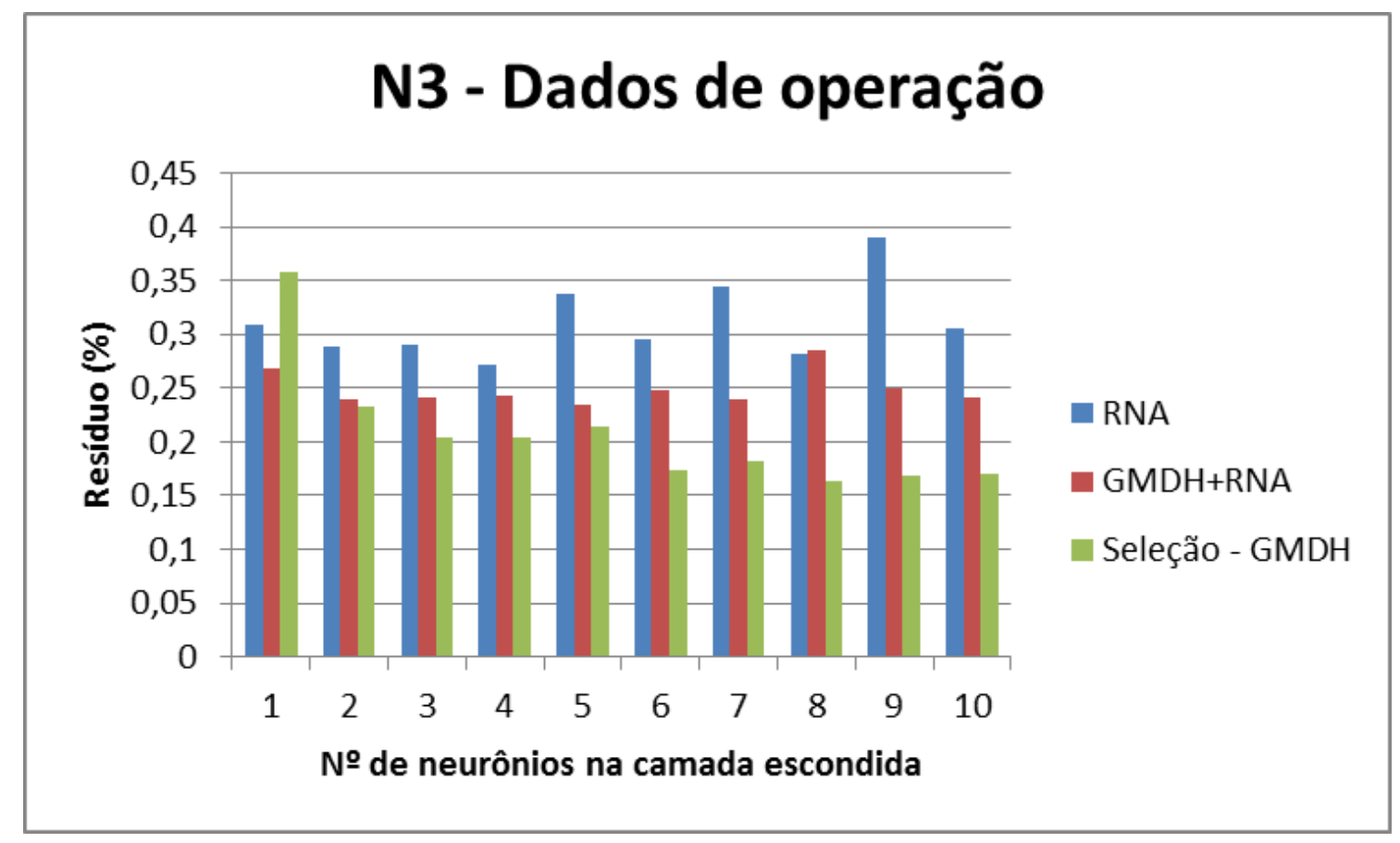

Figura 56. Monitoração de N3 - Comparação entre as metodologias

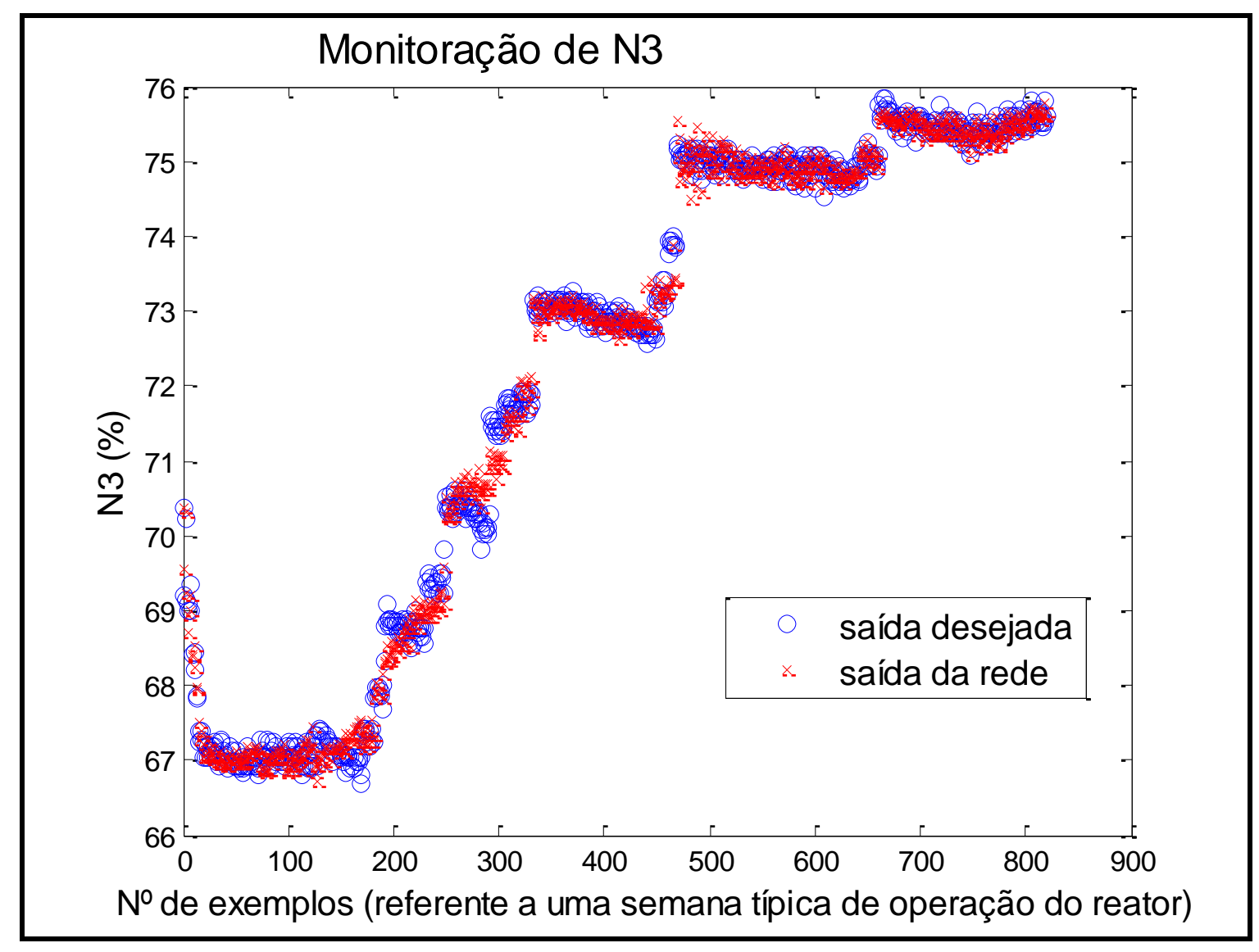

Figura 57. Saída desejada comparada à saída da rede com 8 neurônios na camada escondida 
- Monitoração de N4

Ao realizar o pré-processamento através do estudo das variáveis desconsideradas pelo GMDH, verificou-se que para a variável N4 (modelo 5), as variáveis que tiveram uma relevância maior para o GMDH foram: Z3 e N7. Essas variáveis foram utilizadas no treinamento das RNA, onde a rede com 5 neurônios na camada escondida apresentou o menor resíduo, cujo valor foi 0,1511 (Figura 58). A Figura 59 mostra a saída da rede em função da saída desejada com 5 neurônios na camada escondida.

Como pode ser observado na Figura a seguir, o uso de Seleção - GMDH apresentou os menores valores residuais.

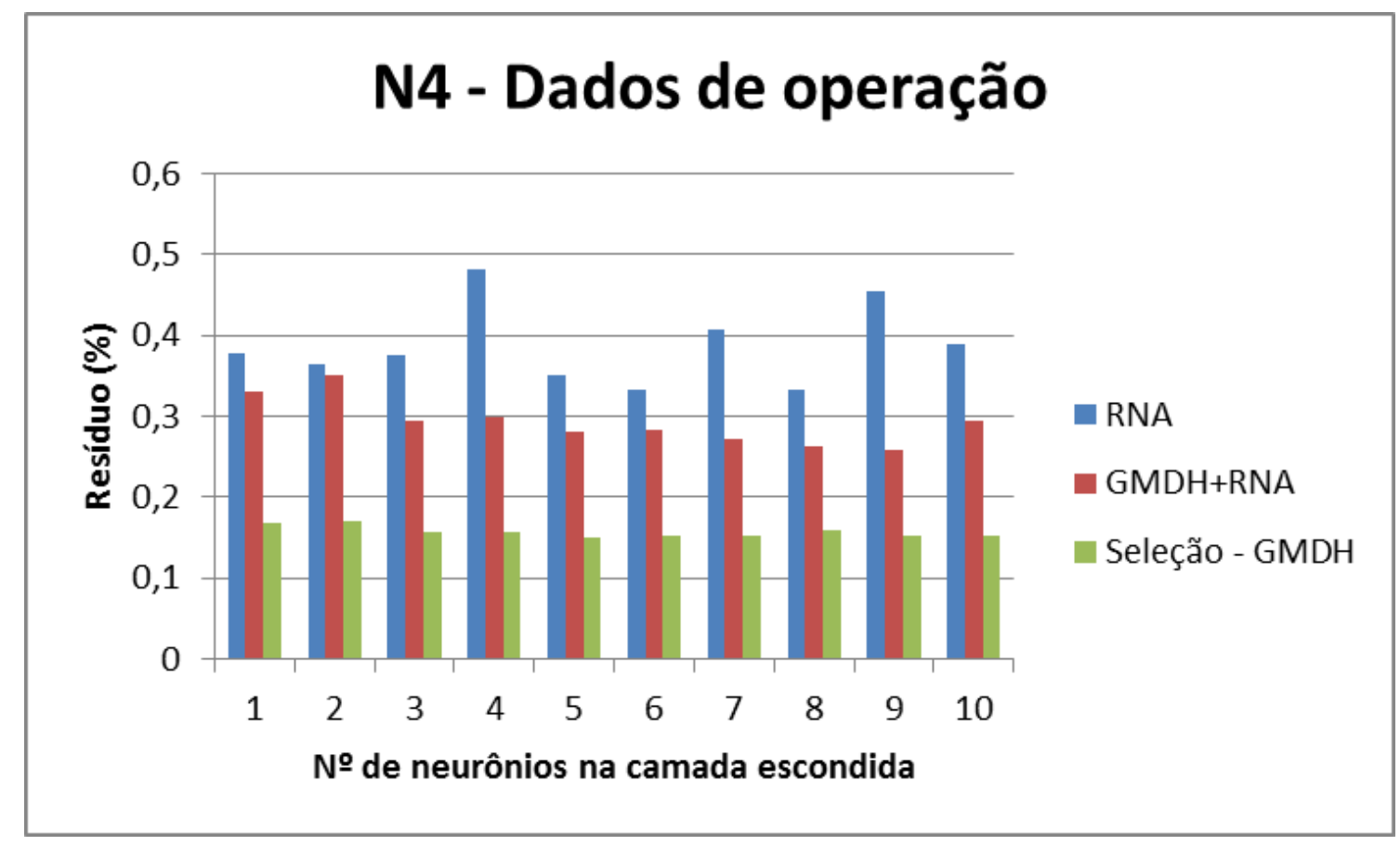

Figura 58. Monitoração de N4 - Comparação entre as metodologias 


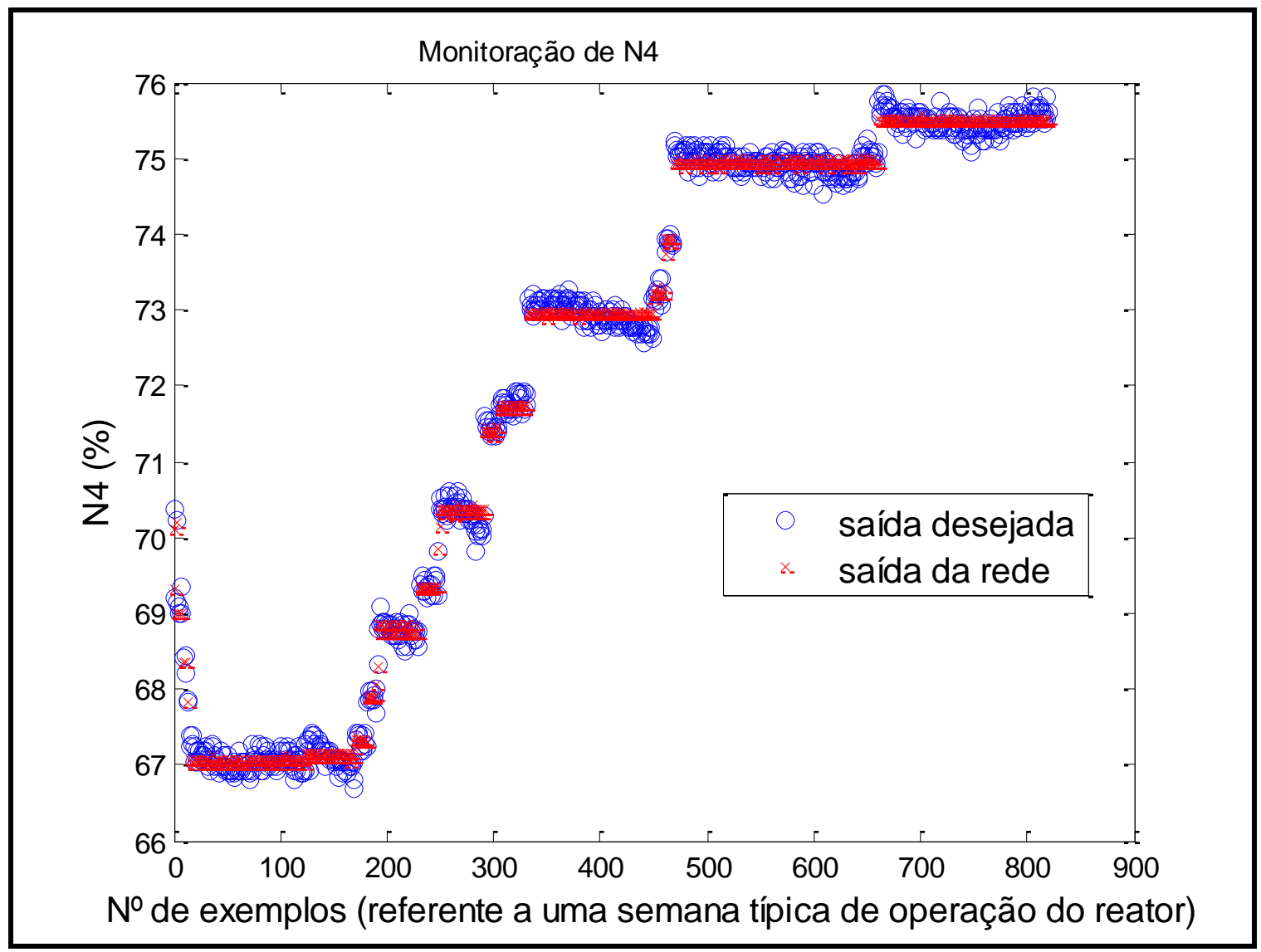

Figura 59. Saída desejada comparada à saída da rede com 5 neurônios na camada escondida

- Monitoração de N6

Ao realizar o pré-processamento através do estudo das variáveis desconsideradas pelo GMDH, verificou-se que para a variável N6 (modelo 5), as variáveis que tiveram uma relevância maior para o GMDH foram: Z1 e N7. Essas variáveis foram utilizadas no treinamento das RNA, onde a rede com 10 neurônios na camada escondida apresentou o menor resíduo, cujo valor foi 0,1342 (Figura 60). A Figura 61 mostra a saída da rede em função da saída desejada com 10 neurônios na camada escondida. Como pode ser observado na Figura a seguir, o uso de Seleção - GMDH apresentou os menores valores residuais. 


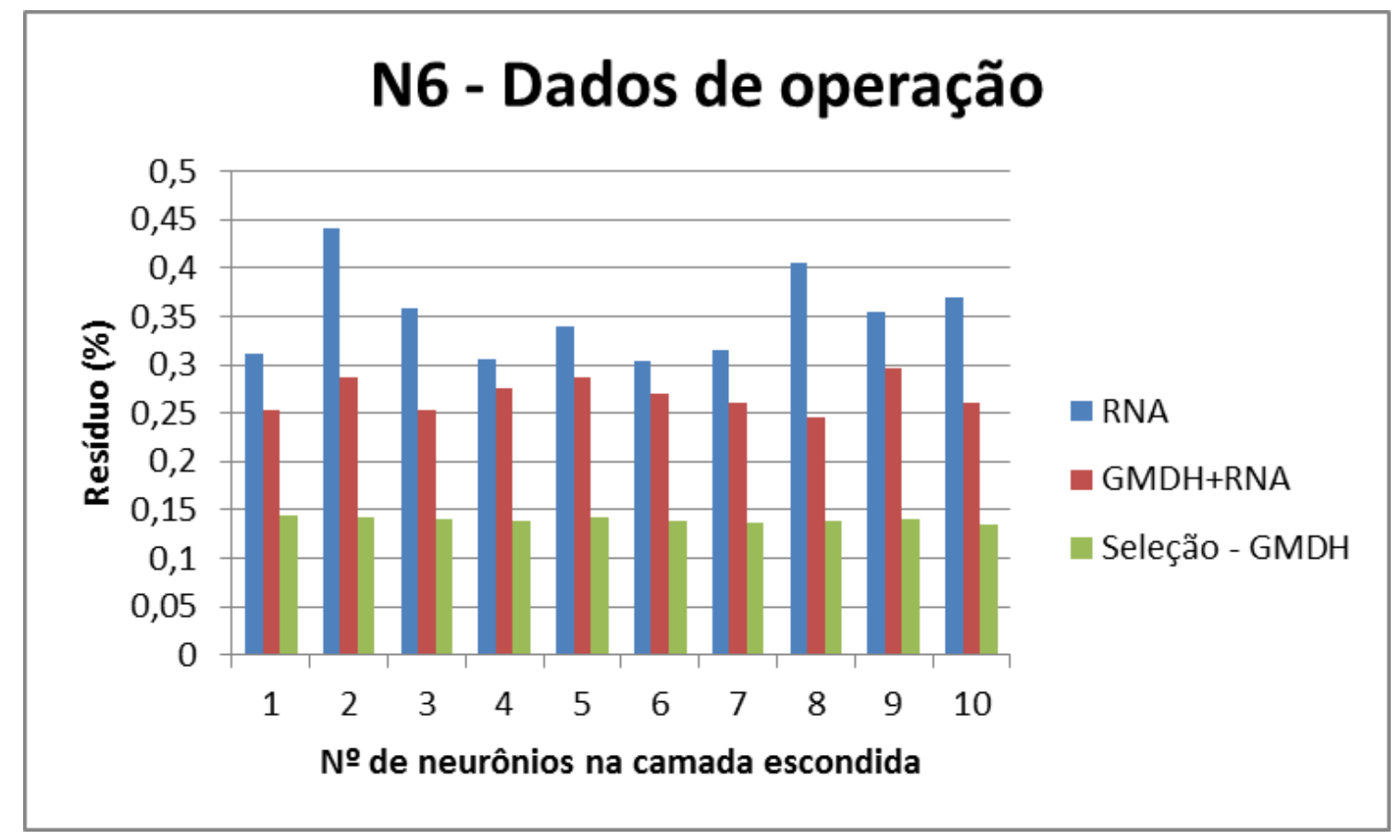

Figura 60. Monitoração de N6 - Comparação entre as metodologias

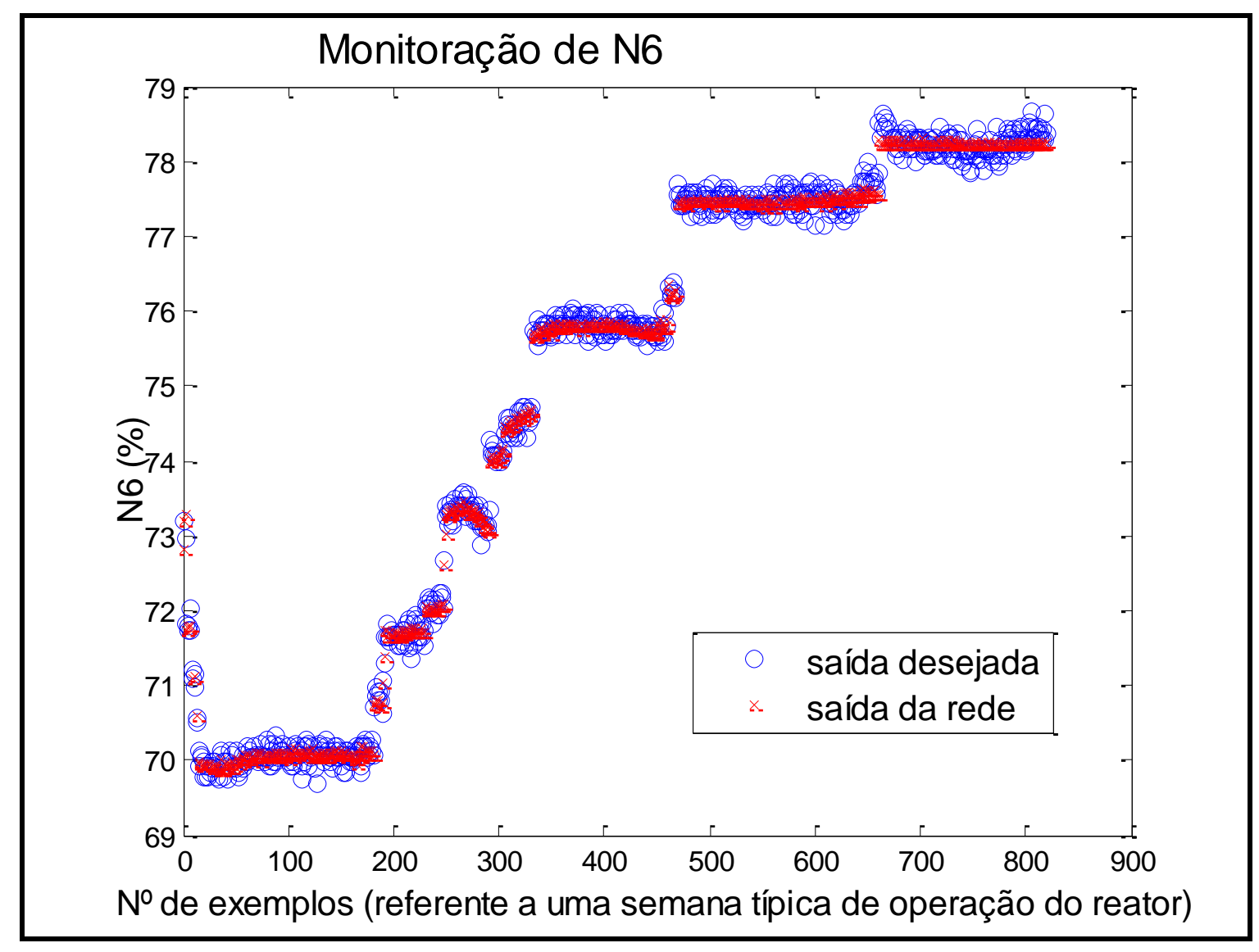

Figura 61. Saída desejada comparada à saída da rede com 10 neurônios na camada escondida 
- Monitoração de N7

Ao realizar o pré-processamento através do estudo das variáveis desconsideradas pelo GMDH, verificou-se que para a variável N7 (modelo 5), as variáveis que tiveram uma relevância maior para o GMDH foram: N6 e R8M3. Essas variáveis foram utilizadas no treinamento das RNA, onde a rede com 9 neurônios na camada escondida apresentou o menor resíduo, cujo valor foi 0,0468 (Figura 62). A Figura 63 mostra a saída da rede em função da saída desejada com 9 neurônios na camada escondida.

Como pode ser observado na Figura a seguir, o uso de Seleção - GMDH apresentou os menores valores residuais.

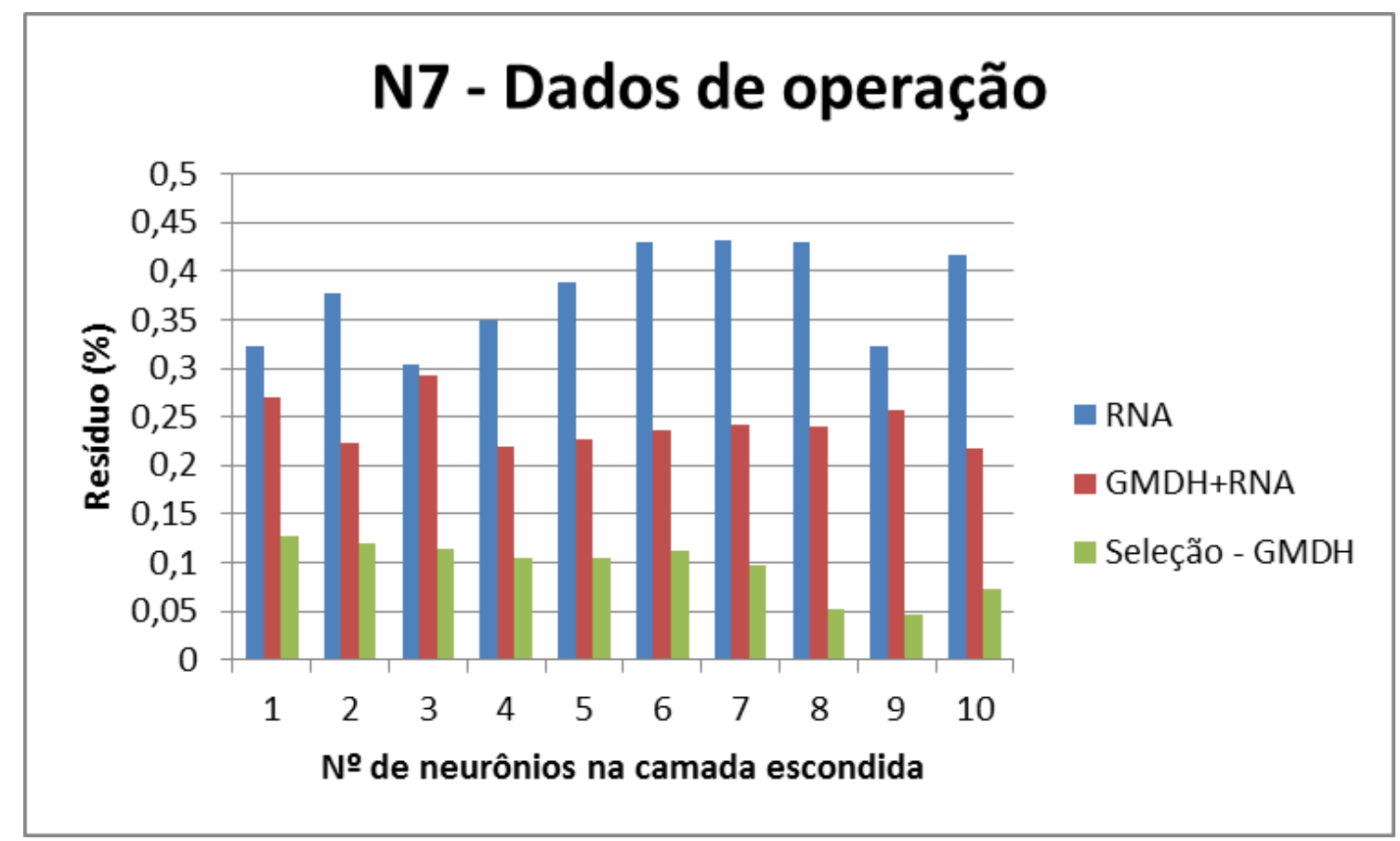

Figura 62. Monitoração de N7 - Comparação entre as metodologias 


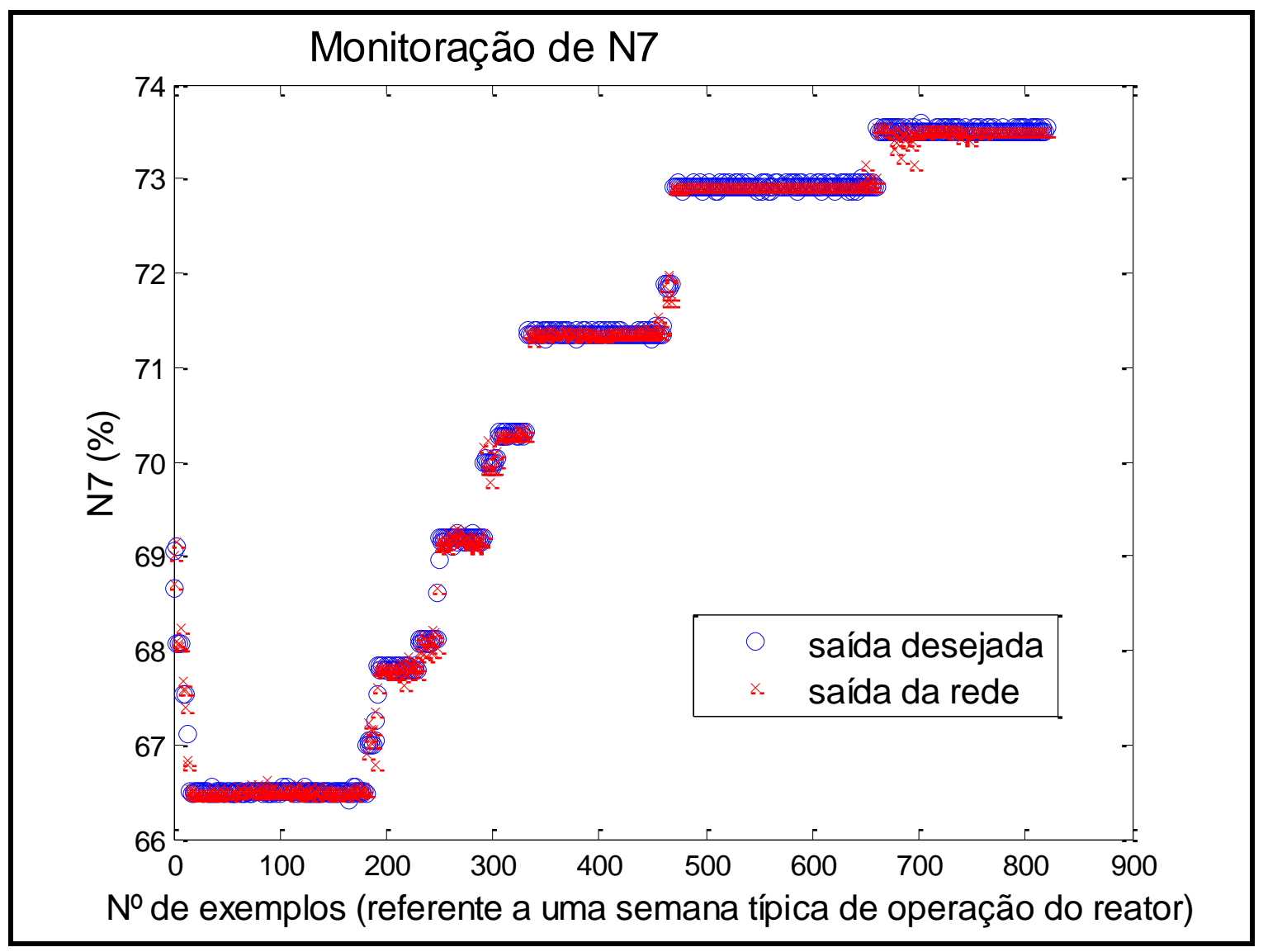

Figura 63. Saída desejada comparada à saída da rede com 9 neurônios na camada escondida

\section{- Monitoração de N8}

Ao realizar o pré-processamento através do estudo das variáveis desconsideradas pelo GMDH, verificou-se que para a variável N8 (modelo 5), as variáveis que tiveram uma relevância maior para o GMDH foram: Z4 e N4. Essas variáveis foram utilizadas no treinamento das RNA, onde a rede com 9 neurônios na camada escondida apresentou o menor resíduo, cujo valor foi 0,4293 (Figura 64). A Figura 65 mostra a saída da rede em função da saída desejada com 9 neurônios na camada escondida

Como pode ser observado na Figura a seguir, o uso de Seleção - GMDH apresentou os menores valores residuais. 


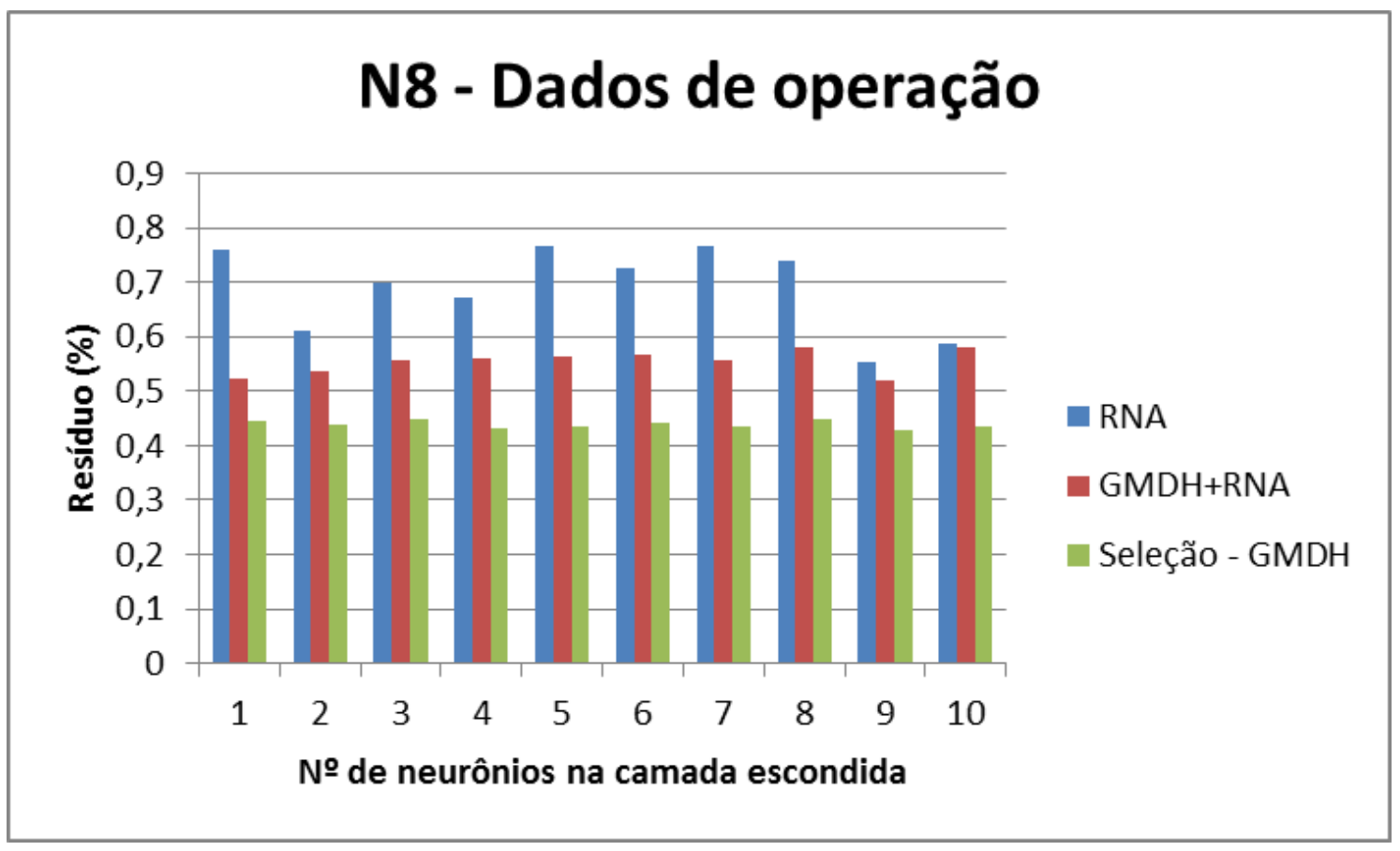

Figura 64. Monitoração de N8 - Comparação entre as metodologias

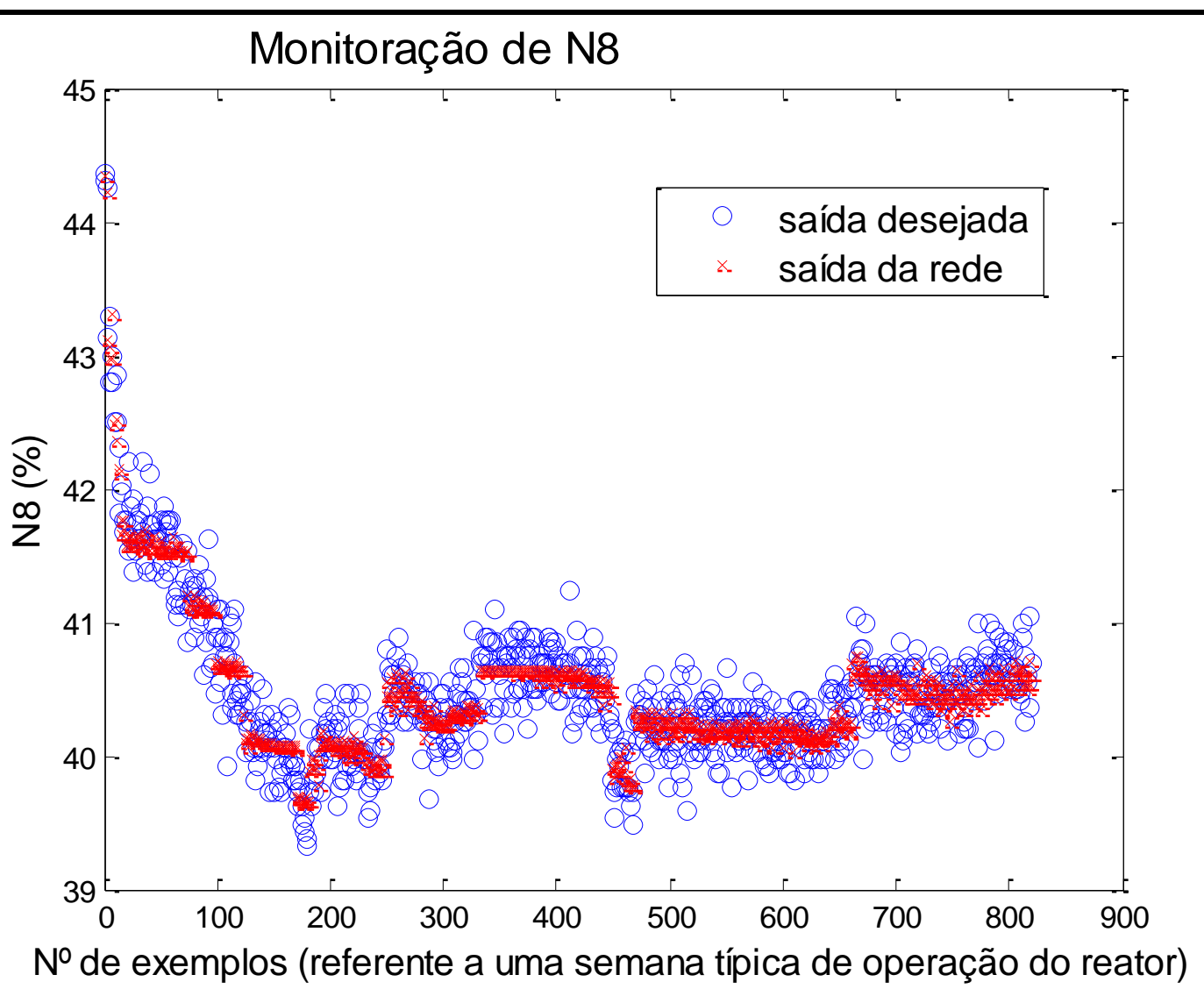

Figura 65. Saída desejada comparada à saída da rede com 9 neurônios na camada escondida 
- Monitoração de T1

Ao realizar o pré-processamento através do estudo das variáveis desconsideradas pelo GMDH, verificou-se que para a variável T1 (modelo 5), as variáveis que tiveram uma relevância maior para o GMDH foram: N3, T2 e T6. Essas variáveis foram utilizadas no treinamento das RNA, onde a rede com 5 neurônios na camada escondida apresentou o menor resíduo, cujo valor foi 0,1137 (Figura 66). A Figura 67 mostra a saída da rede em função da saída desejada com 5 neurônios na camada escondida

Como pode ser observado na Figura a seguir, o uso de Seleção - GMDH apresentou os menores valores residuais.

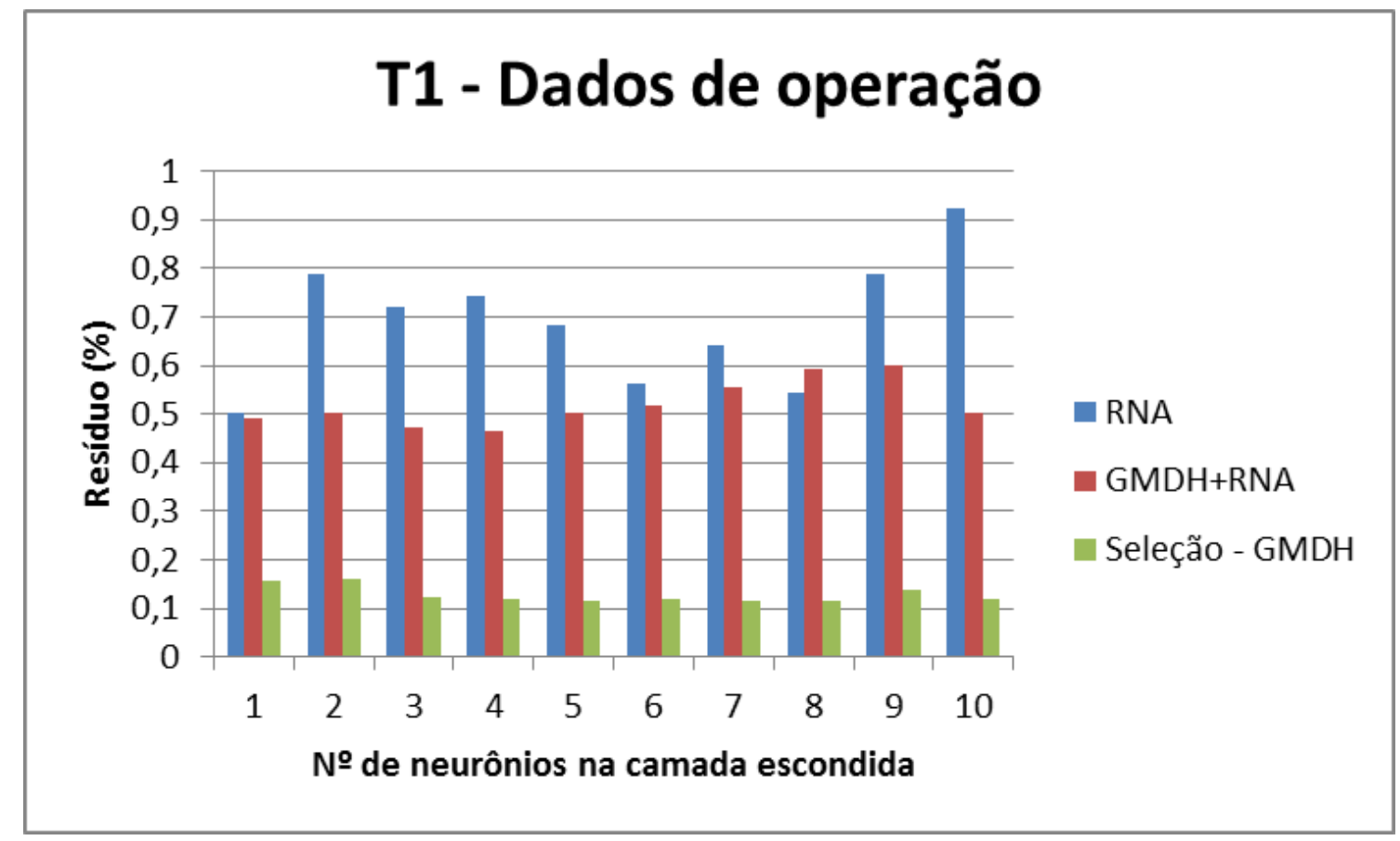

Figura 66. Monitoração de T1 - Comparação entre as metodologias 


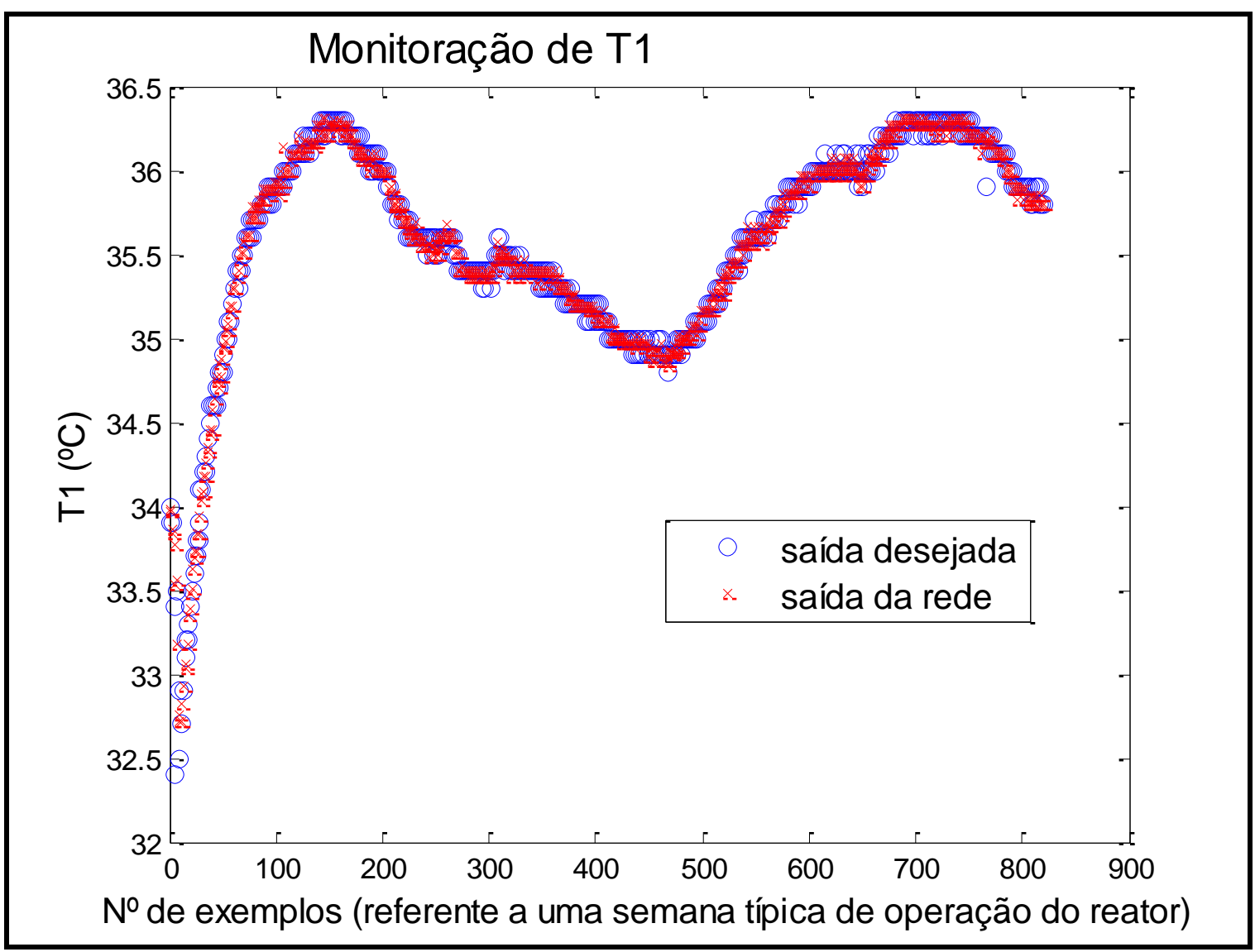

Figura 67. Saída desejada comparada à saída da rede com 5 neurônios na camada escondida

- Monitoração de T2

Ao realizar o pré-processamento através do estudo das variáveis desconsideradas pelo GMDH, verificou-se que para a variável T2 (modelo 5), as variáveis que tiveram uma relevância maior para o GMDH foram: T1 e T4. Essas variáveis foram utilizadas no treinamento das RNA, onde a rede com 9 neurônios na camada escondida apresentou o menor resíduo, cujo valor foi 0,1049 (Figura 68). A Figura 69 mostra a saída da rede em função da saída desejada com 9 neurônios na camada escondida. Como pode ser observado na Figura a seguir, o uso de Seleção - GMDH apresentou os menores valores residuais. 


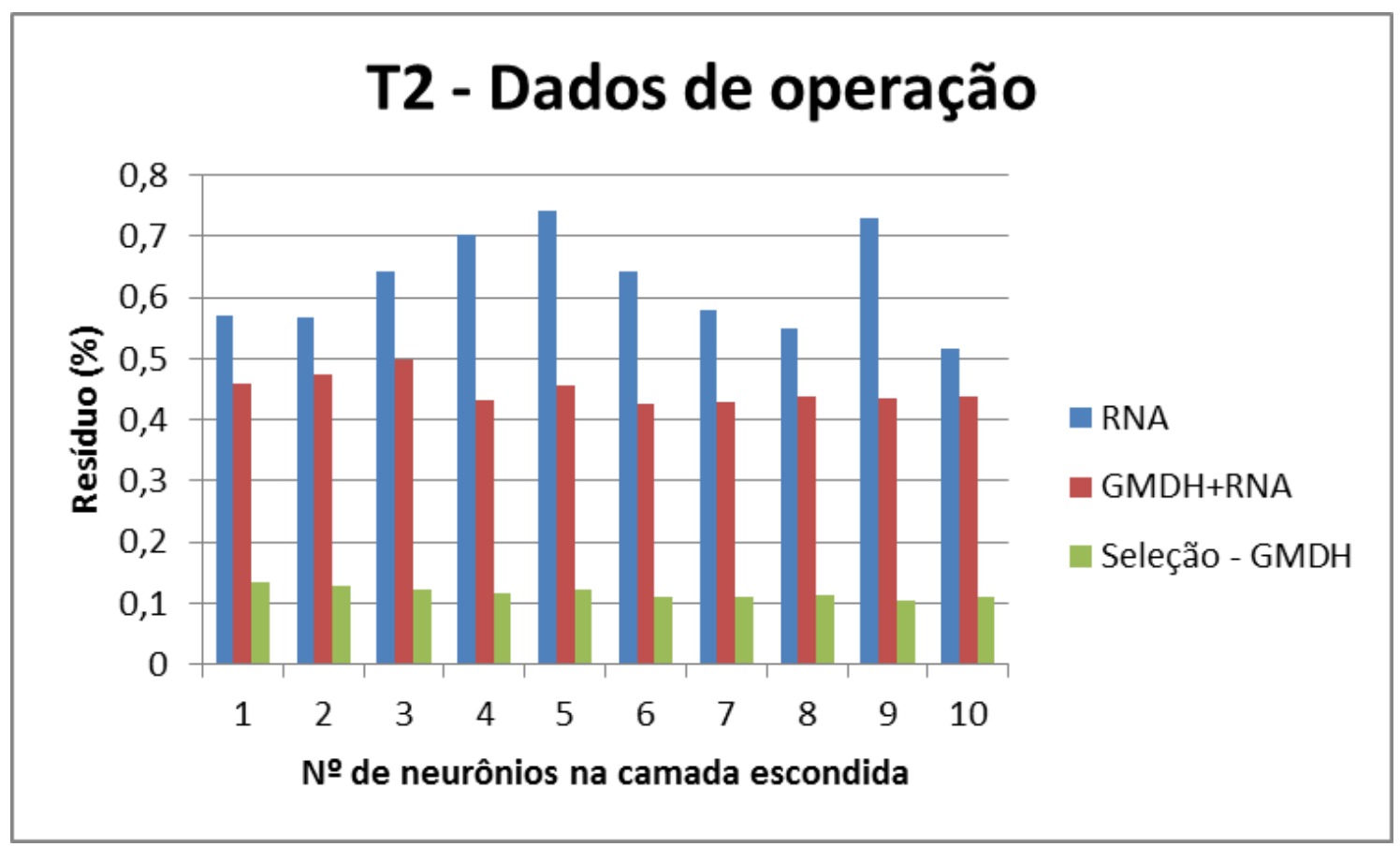

Figura 68. Monitoração de T2 - Comparação entre as metodologias

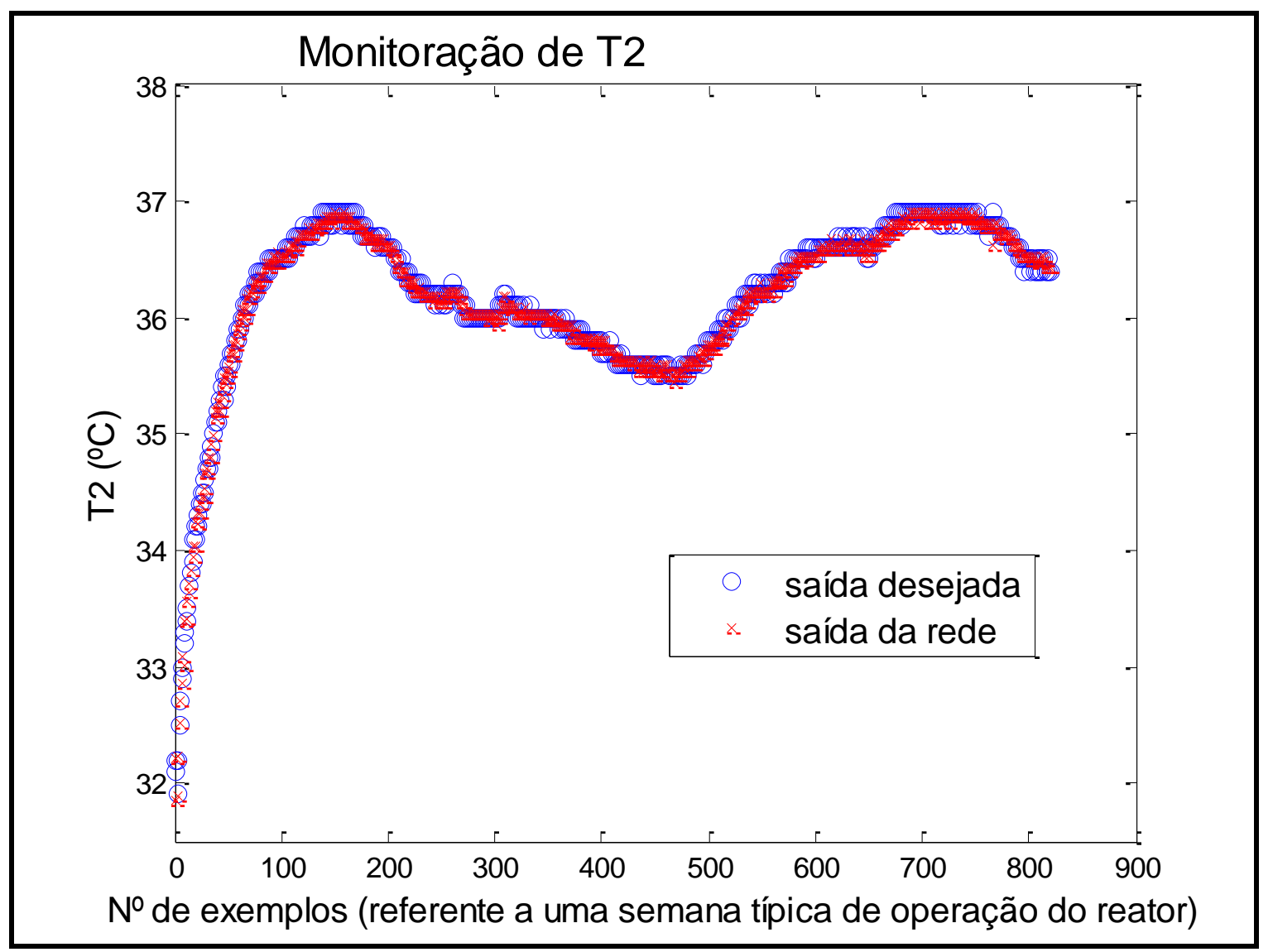

Figura 69. Saída desejada comparada à saída da rede com 9 neurônios na camada escondida 
- Monitoração de T3

Ao realizar o pré-processamento através do estudo das variáveis desconsideradas pelo GMDH, verificou-se que para a variável T3 (modelo 5), as variáveis que tiveram uma relevância maior para o GMDH foram: T1 e T6. Essas variáveis foram utilizadas no treinamento das RNA, onde a rede com 2 neurônios na camada escondida apresentou o menor resíduo, cujo valor foi 0,1180 (Figura 70). A Figura 71 mostra a saída da rede em função da saída desejada com 2 neurônios na camada escondida

Como pode ser observado na Figura a seguir, o uso de Seleção - GMDH apresentou os menores valores residuais.

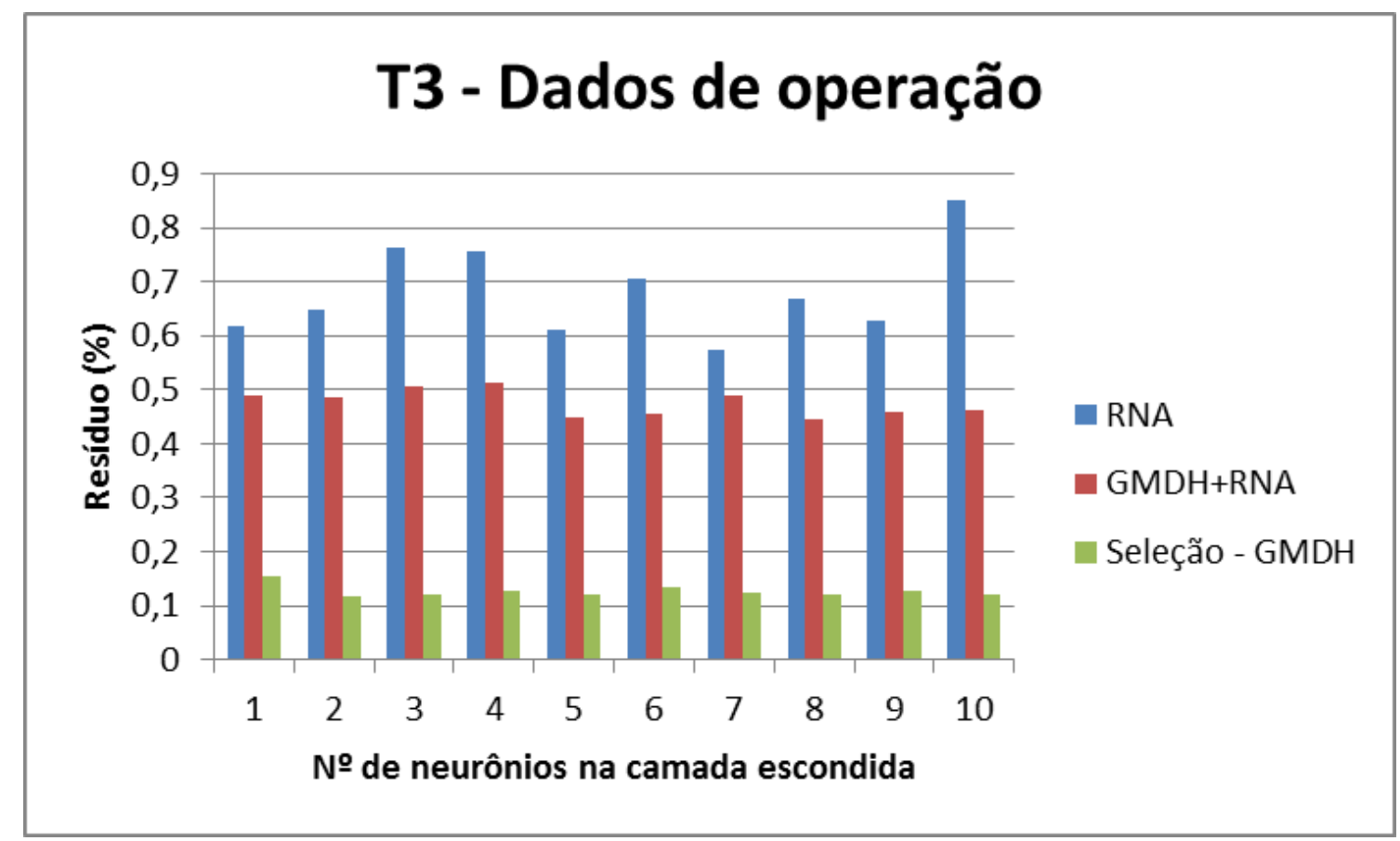

Figura 70. Monitoração de T3 - Comparação entre as metodologias 


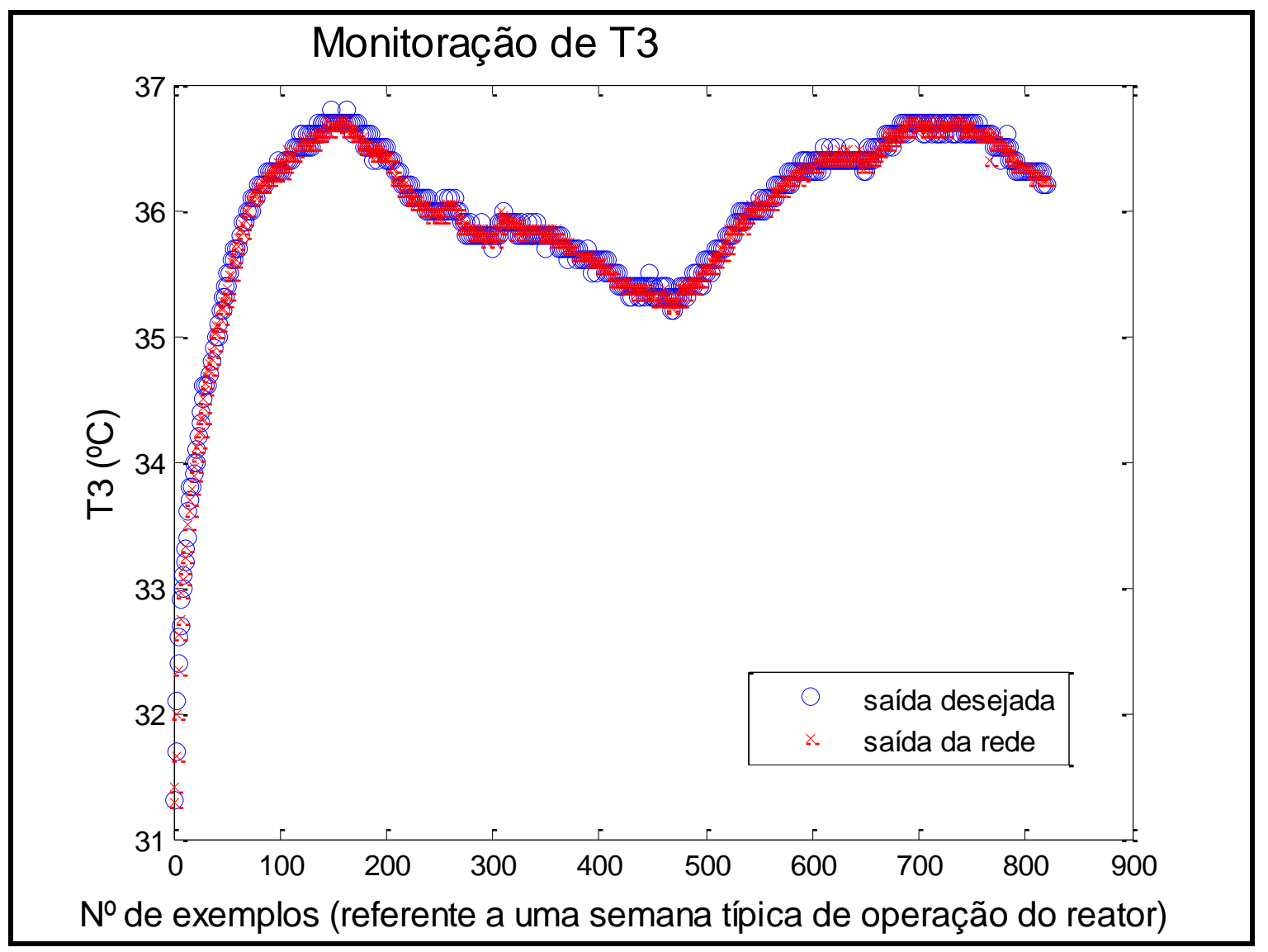

Figura 71. Saída desejada comparada à saída da rede com 2 neurônios na camada escondida

\section{- Monitoração de T4}

Ao realizar o pré-processamento através do estudo das variáveis desconsideradas pelo GMDH, verificou-se que para a variável T4 (modelo 5), as variáveis que tiveram uma relevância maior para o GMDH foram: T1 e T6. Essas variáveis foram utilizadas no treinamento das RNA, onde a rede com 10 neurônios na camada escondida apresentou o menor resíduo, cujo valor foi 0,0023 (Figura 72). A Figura 73 mostra a saída da rede em função da saída desejada com 10 neurônios na camada escondida.

Como pode ser observado na Figura a seguir, o uso de Seleção - GMDH apresentou os menores valores residuais. 


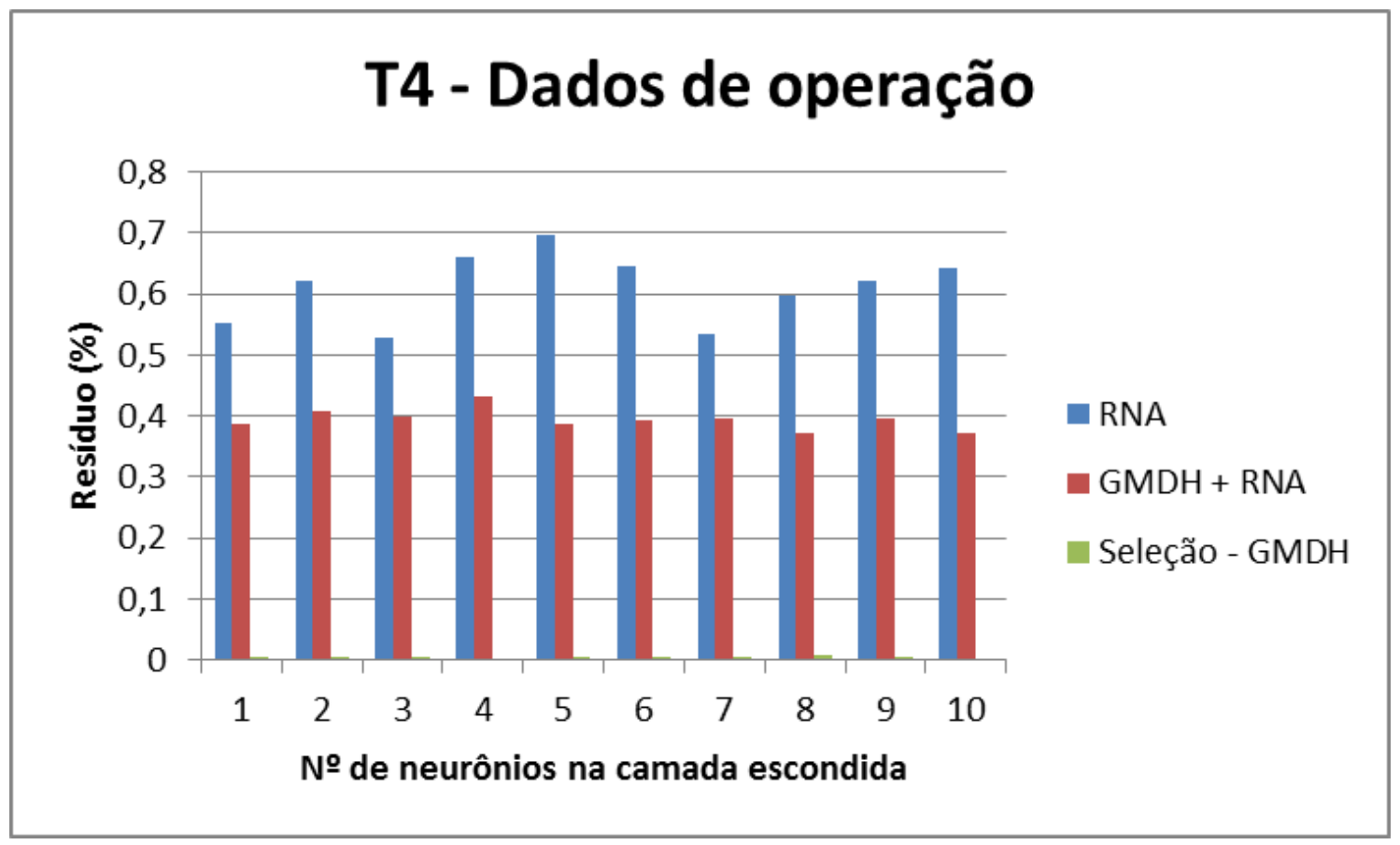

Figura 72. Monitoração de T4 - Comparação entre as metodologias

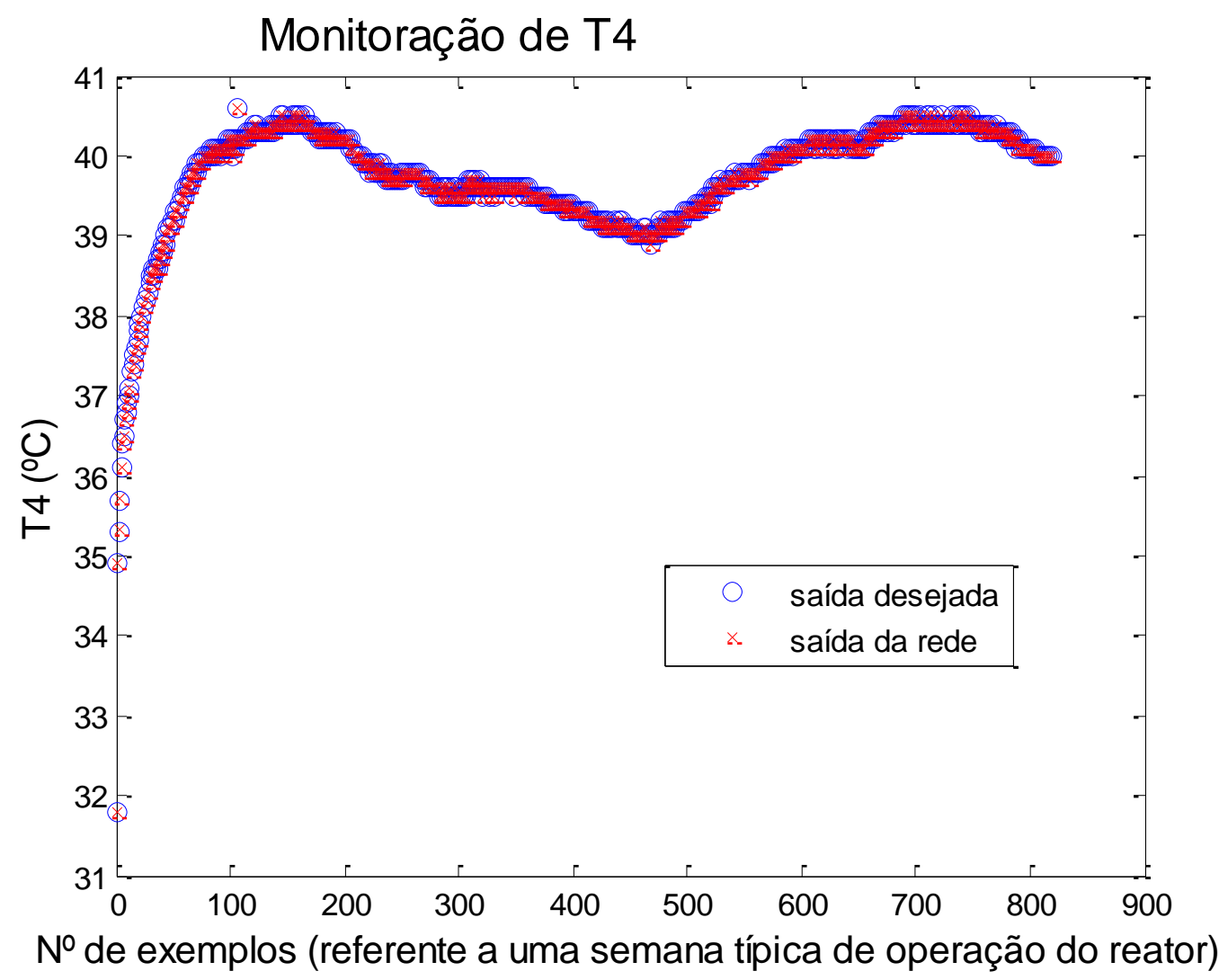

Figura 73. Saída desejada comparada à saída da rede com 10 neurônios na camada escondida 
- Monitoração de T6

Ao realizar o pré-processamento através do estudo das variáveis desconsideradas pelo GMDH, verificou-se que para a variável T6 (modelo 5), as variáveis que tiveram uma relevância maior para o GMDH foram: T4 e T7. Essas variáveis foram utilizadas no treinamento das RNA, onde a rede com 4 neurônios na camada escondida apresentou o menor resíduo, cujo valor foi 0,1041 (Figura 74). A Figura 75 mostra a saída da rede em função da saída desejada com 4 neurônios na camada escondida.

Como pode ser observado na Figura a seguir, o uso de Seleção - GMDH apresentou os menores valores residuais.

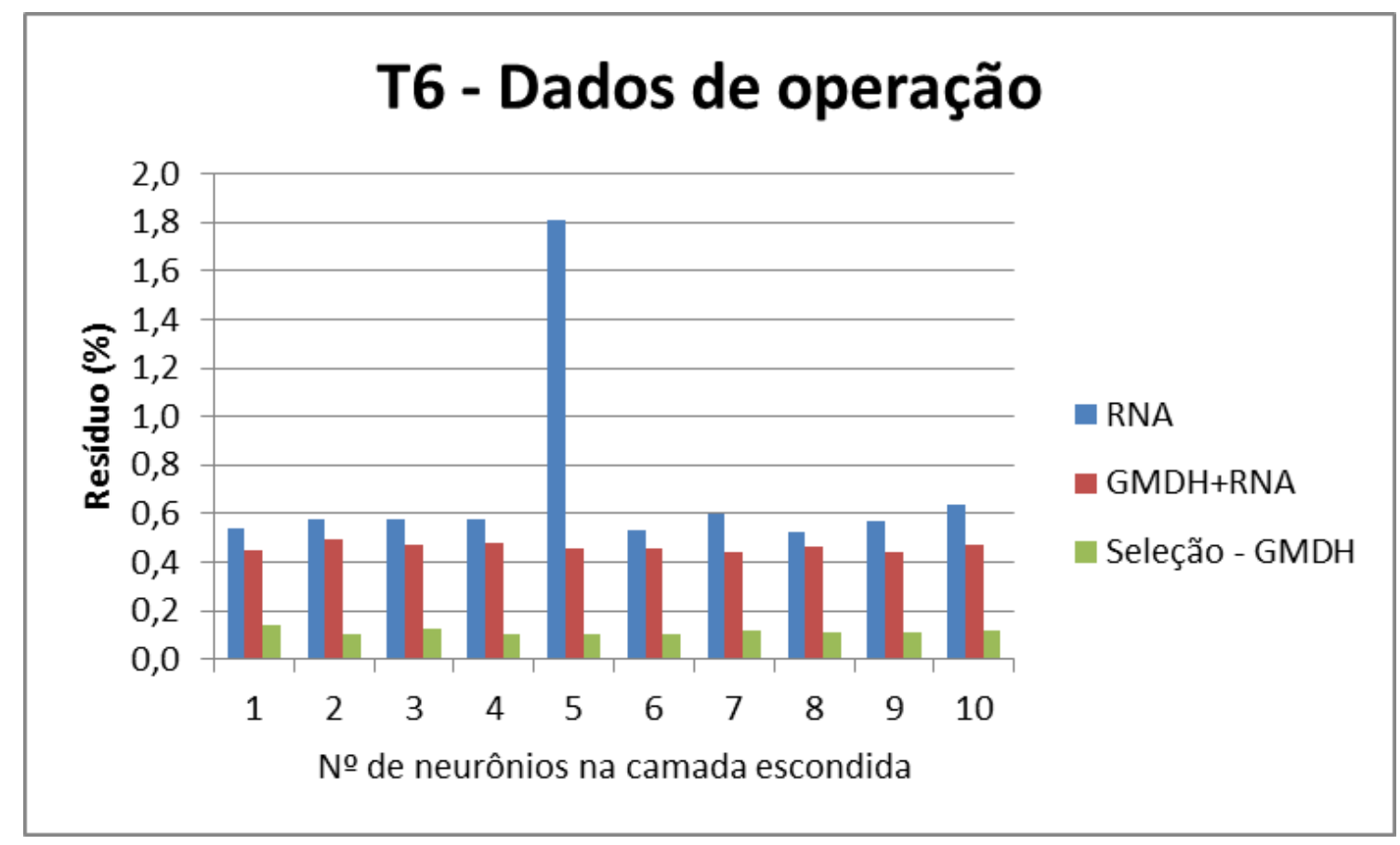

Figura 74. Monitoração de T6 - Comparação entre as metodologias 


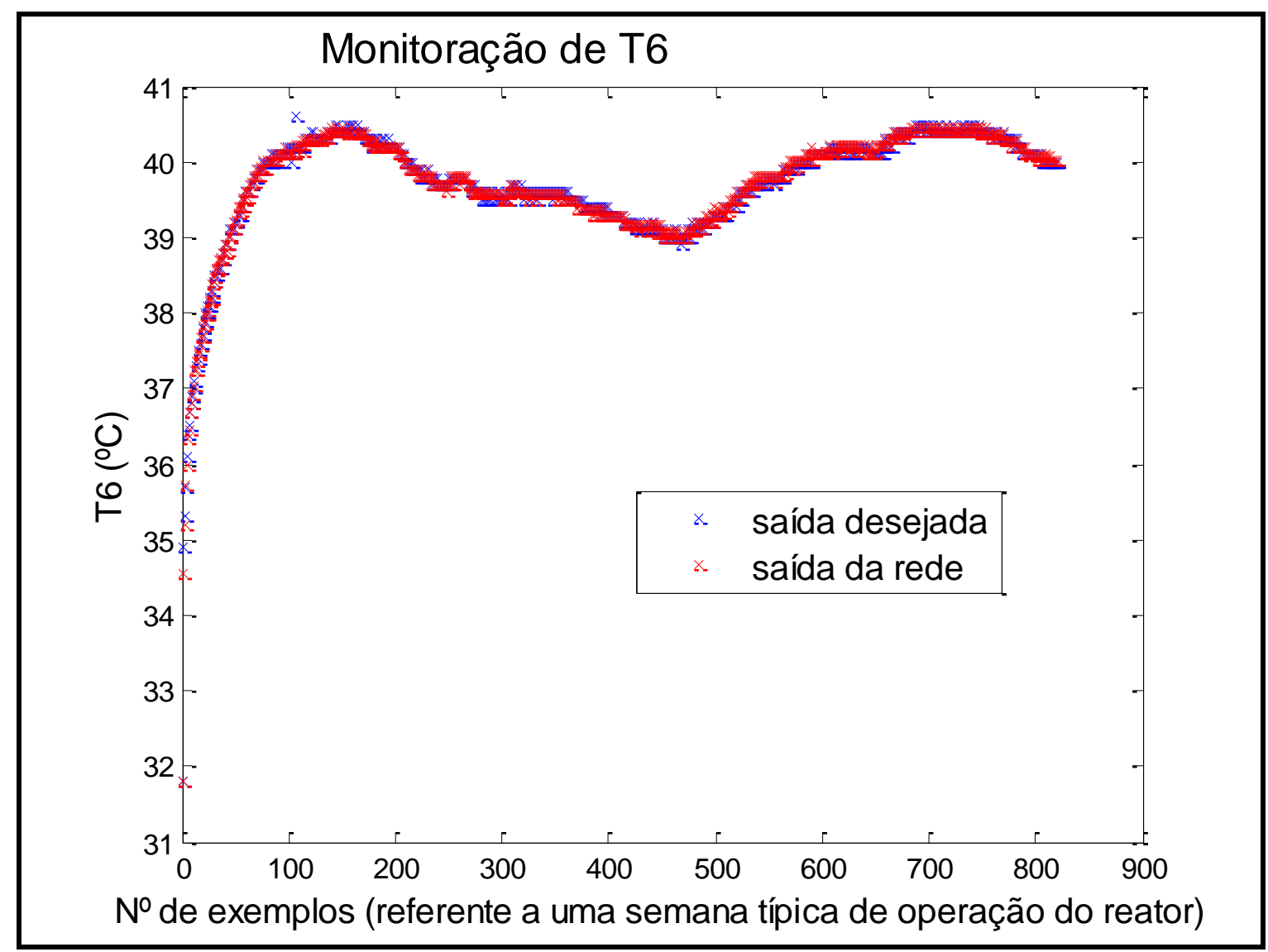

Figura 75. Saída desejada comparada à saída da rede com 4 neurônios na camada escondida

\section{- Monitoração de T7}

Ao realizar o pré-processamento através do estudo das variáveis desconsideradas pelo GMDH, verificou-se que para a variável T7 (modelo 5), as variáveis que tiveram uma relevância maior para o GMDH foram: T6 e T8. Essas variáveis foram utilizadas no treinamento das RNA, onde a rede com 6 neurônios na camada escondida apresentou o menor resíduo, cujo valor foi 0,1436 (Figura 76). A Figura 77 mostra a saída da rede em função da saída desejada com 6 neurônios na camada escondida.

Como pode ser observado na Figura a seguir, o uso de Seleção - GMDH apresentou os menores valores residuais. 


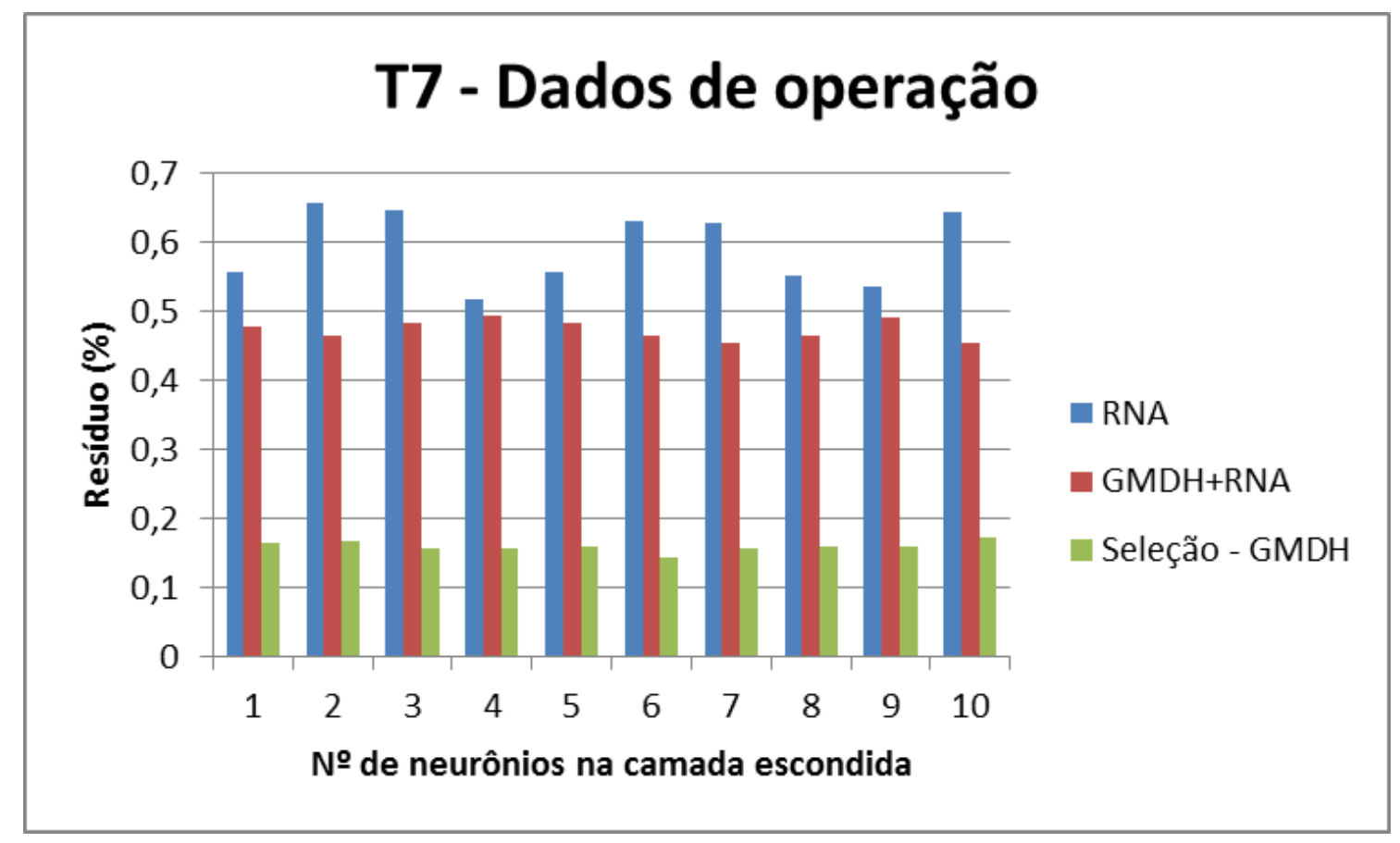

Figura 76. Monitoração de T7 - Comparação entre as metodologias

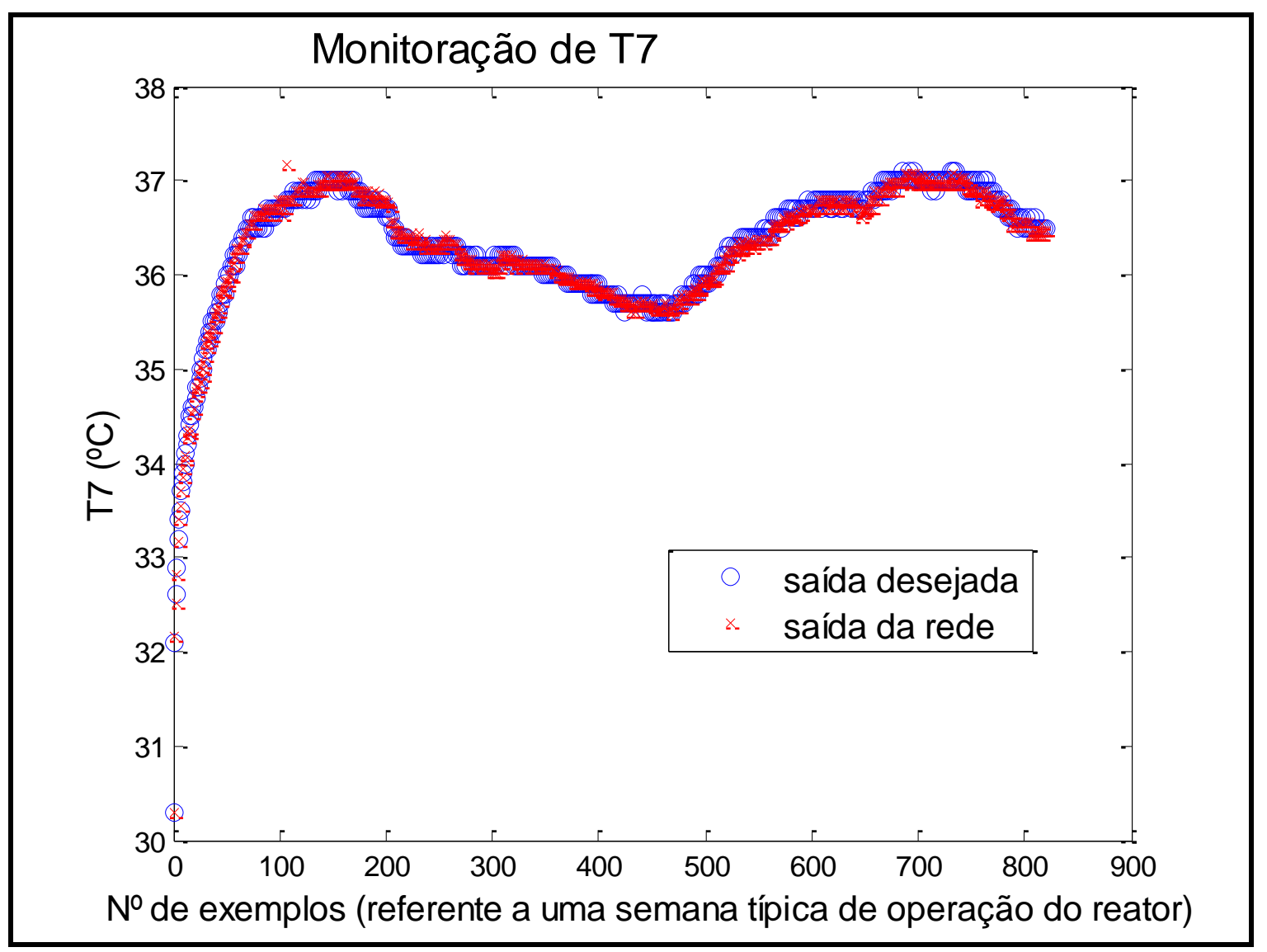

Figura 77. Saída desejada comparada à saída da rede com 6 neurônios na camada escondida 
- Monitoração de T8

Ao realizar o pré-processamento através do estudo das variáveis desconsideradas pelo GMDH, verificou-se que para a variável T8 (modelo 5), as variáveis que tiveram uma relevância maior para o GMDH foram: Z1, R7M3, R11M3, T6 e T9. Essas variáveis foram utilizadas no treinamento das RNA, onde a rede com 7 neurônios na camada escondida apresentou o menor resíduo, cujo valor foi 0,2004 (Figura 78). A Figura 79 mostra a saída da rede em função da saída desejada com 7 neurônios na camada escondida.

Como pode ser observado na Figura a seguir, o uso de Seleção - GMDH apresentou os menores valores residuais.

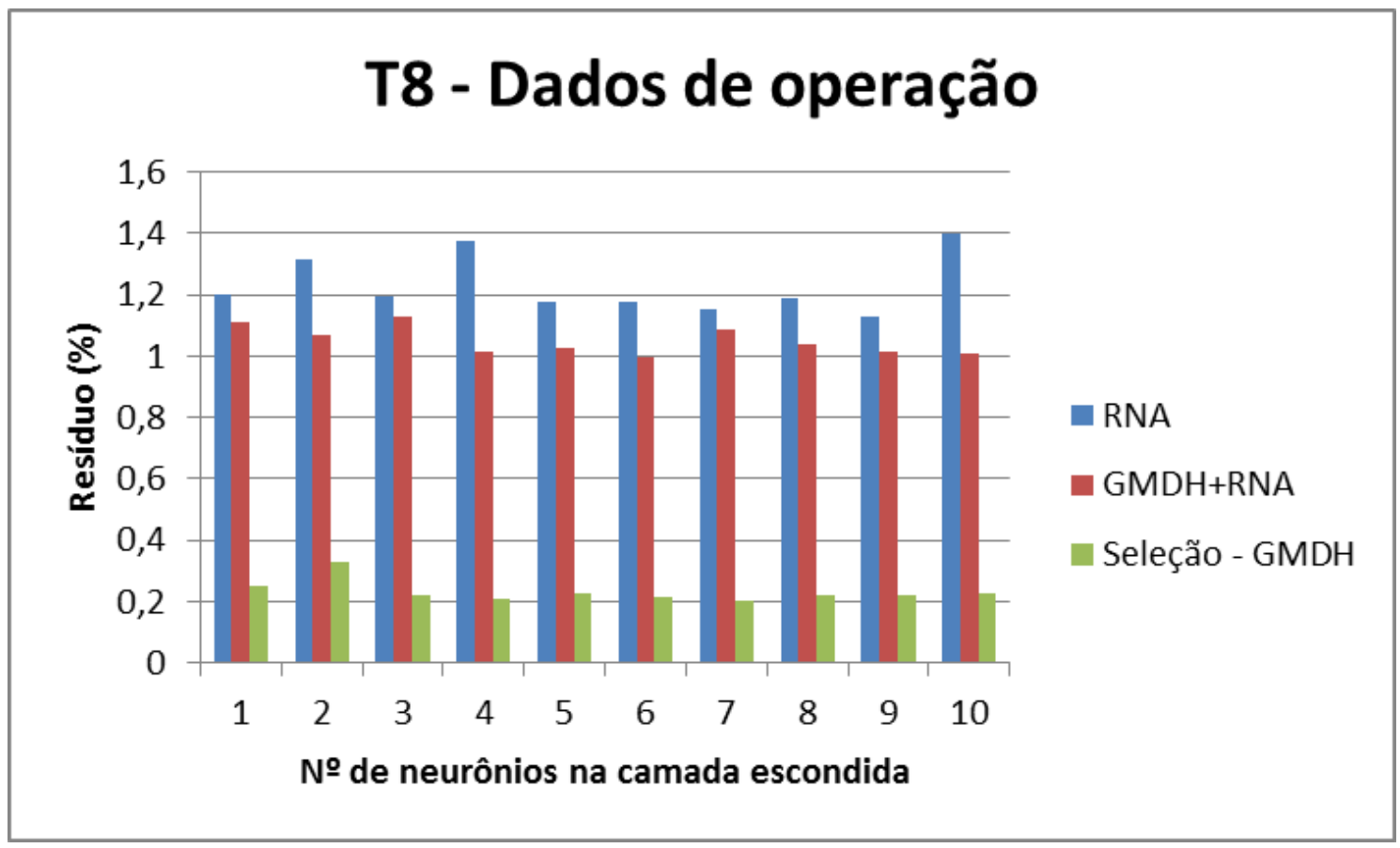

Figura 78. Monitoração de T8 - Comparação entre as metodologias 


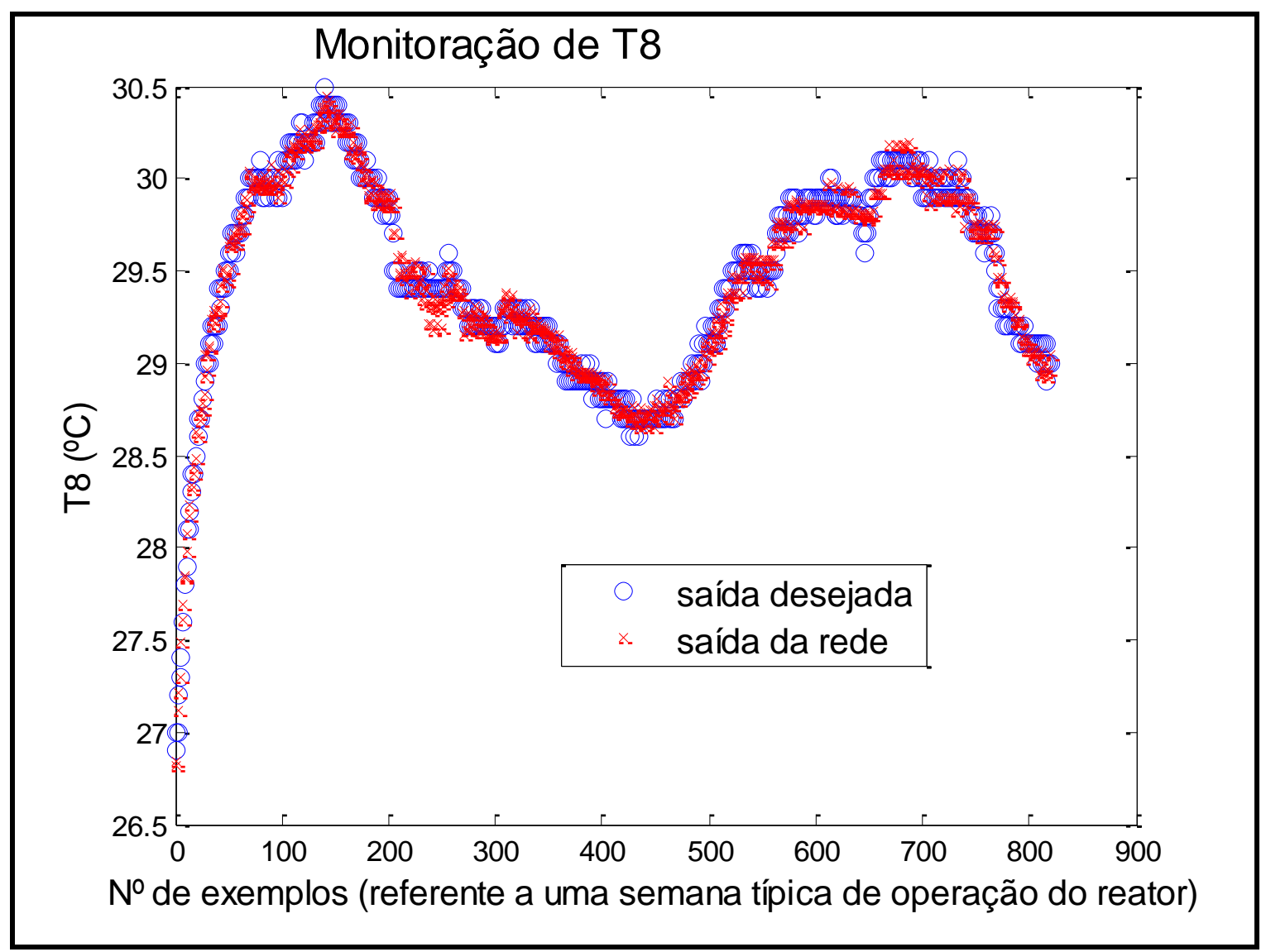

Figura 79. Saída desejada comparada à saída da rede com 7 neurônios na camada escondida

\section{- Monitoração de T9}

Ao realizar o pré-processamento através do estudo das variáveis desconsideradas pelo GMDH, verificou-se que para a variável T9 (modelo 5), as variáveis que tiveram uma relevância maior para o GMDH foram: T6 e T8. Essas variáveis foram utilizadas no treinamento das RNA, onde a rede com 5 neurônios na camada escondida apresentou o menor resíduo, cujo valor foi 0,1229 (Figura 80). A Figura 81 mostra a saída da rede em função da saída desejada com 5 neurônios na camada escondida. Como pode ser observado na Figura a seguir, o uso de Seleção - GMDH apresentou os menores valores residuais. 


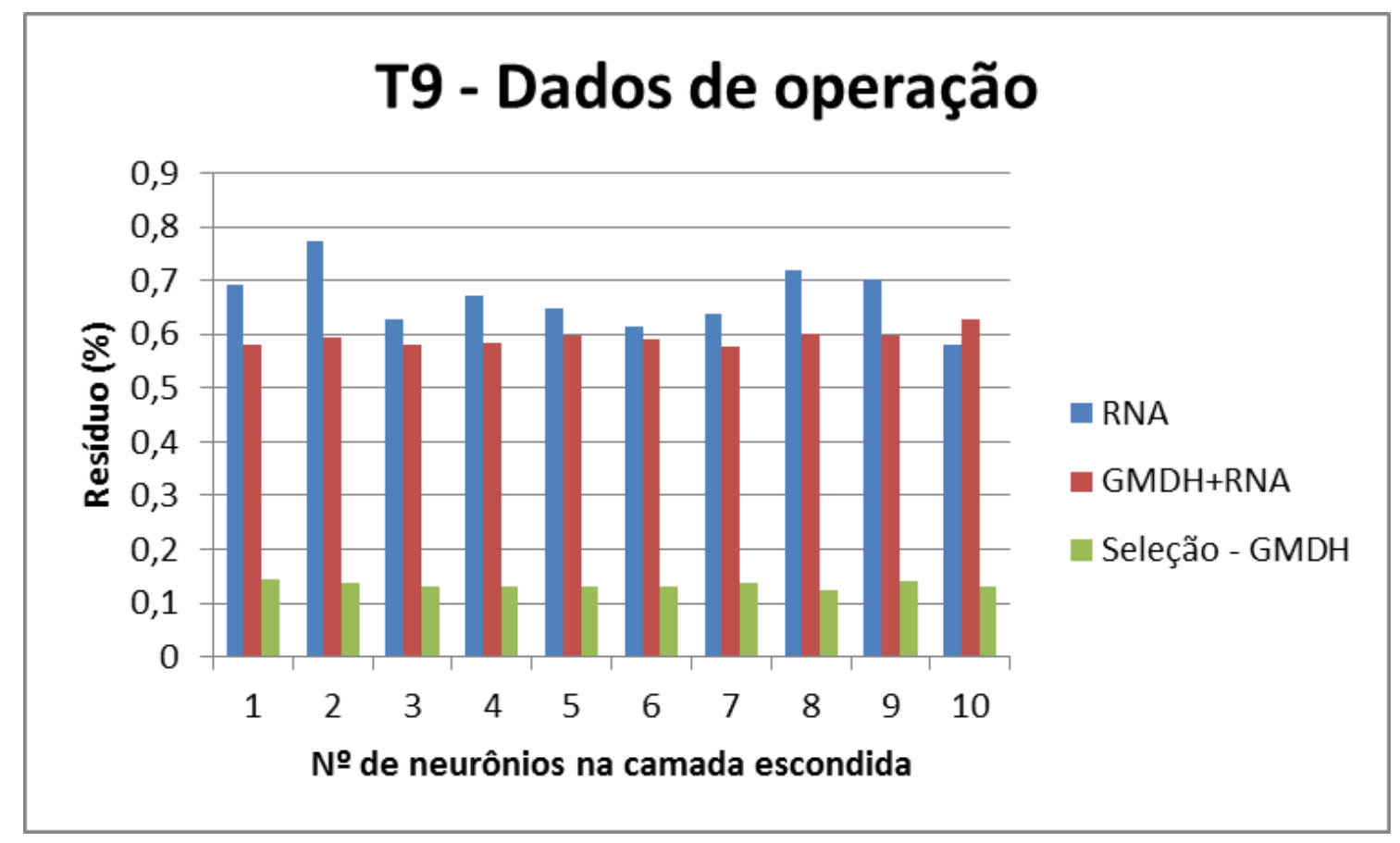

Figura 80. Monitoração de T9 - Comparação entre as metodologias

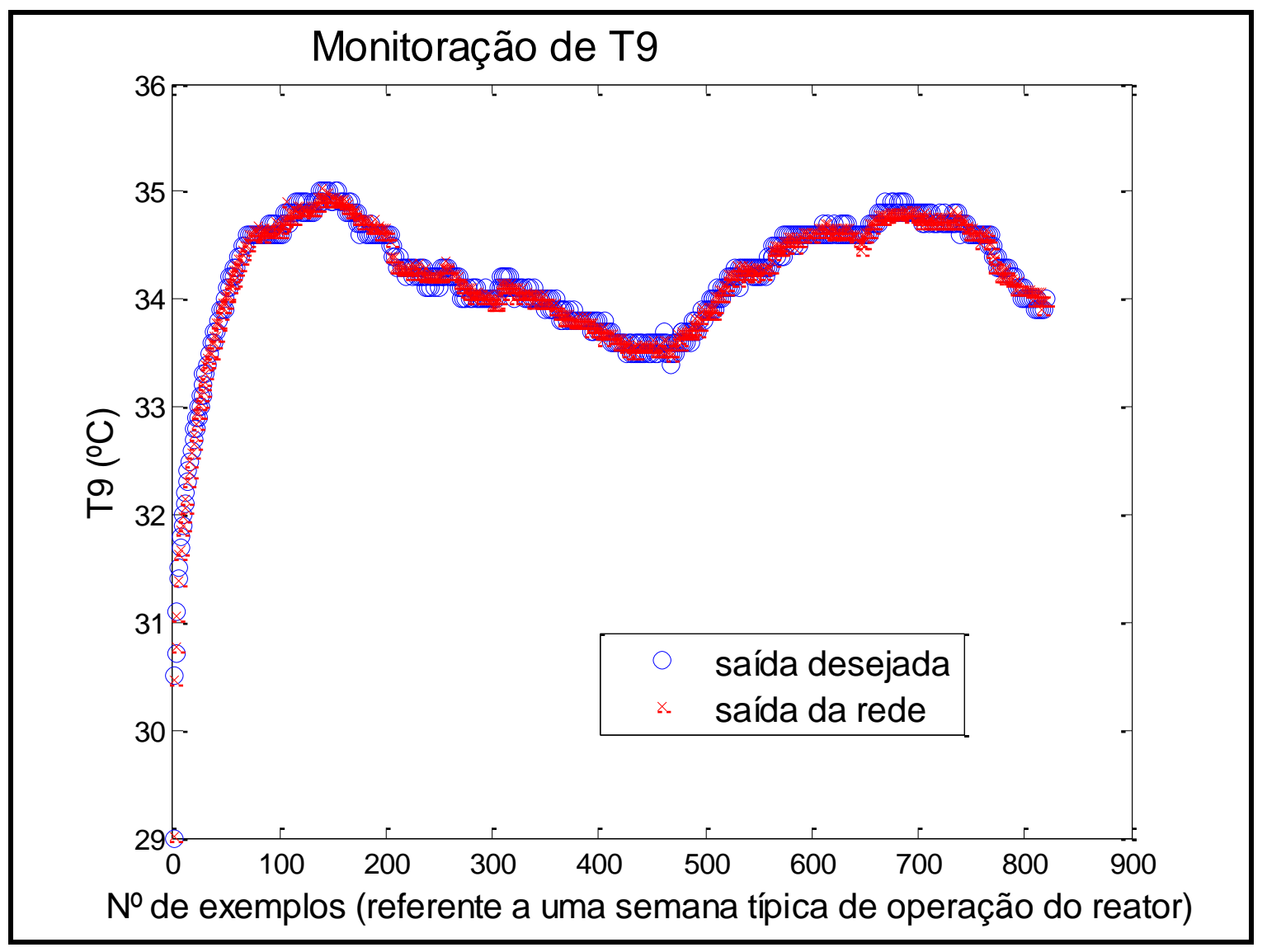

Figura 81. Saída desejada comparada à saída da rede com 5 neurônios na camada escondida 
- Monitoração de RlM3

Ao realizar o pré-processamento através do estudo das variáveis desconsideradas pelo GMDH, verificou-se que para a variável R1M3 (modelo 5), as variáveis que tiveram uma relevância maior para o GMDH foram: Z1, R2M3, R7M3, R8M3 e R11M3. Essas variáveis foram utilizadas no treinamento das RNA, onde a rede com 10 neurônios na camada escondida apresentou o menor resíduo, cujo valor foi 2,9378 (Figura 82). A Figura 83 mostra a saída da rede em função da saída desejada com 10 neurônios na camada escondida.

Como pode ser observado na Figura a seguir, o uso de Seleção - GMDH apresentou os menores valores residuais.

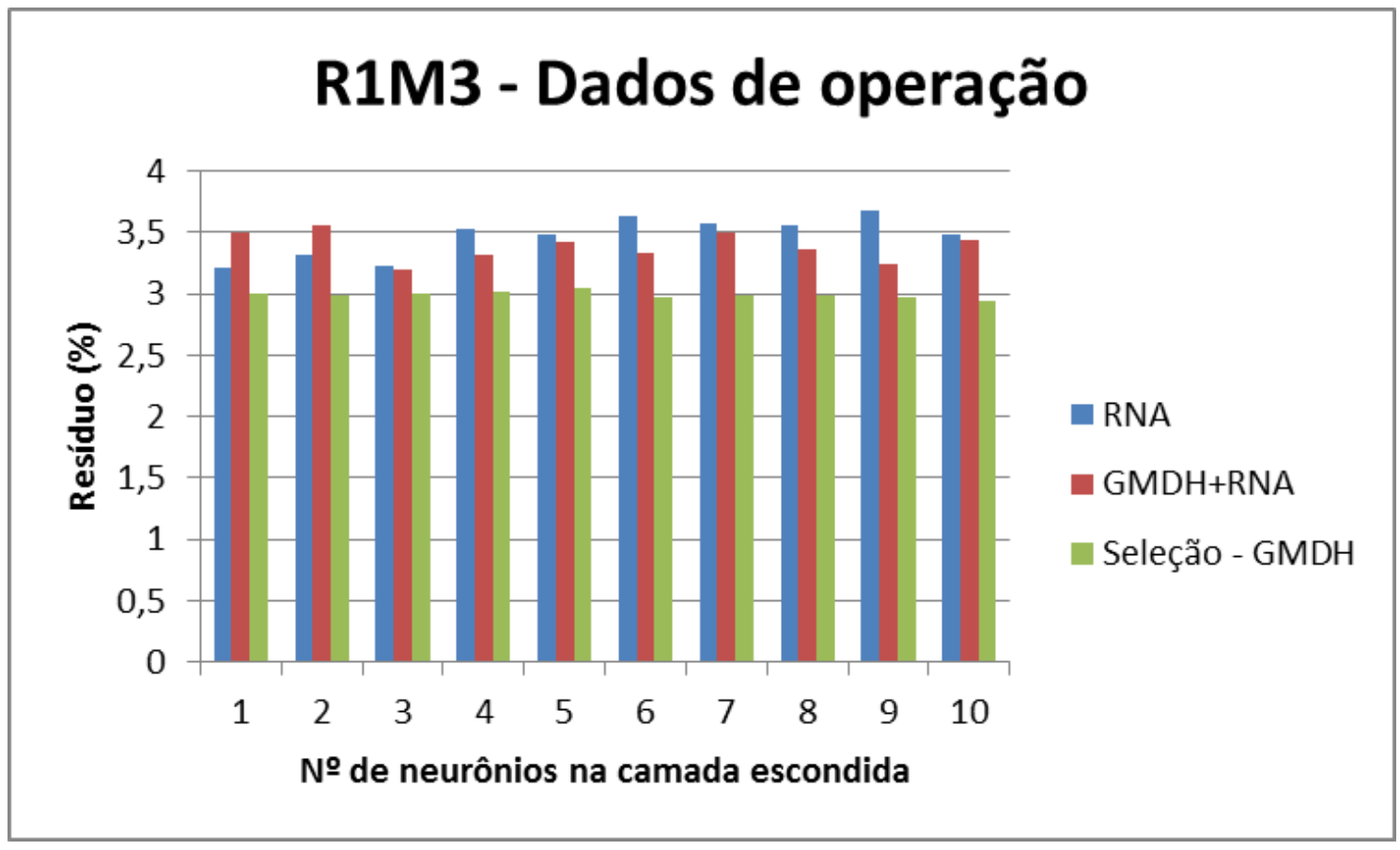

Figura 82. Monitoração de R1M3 - Comparação entre as metodologias 


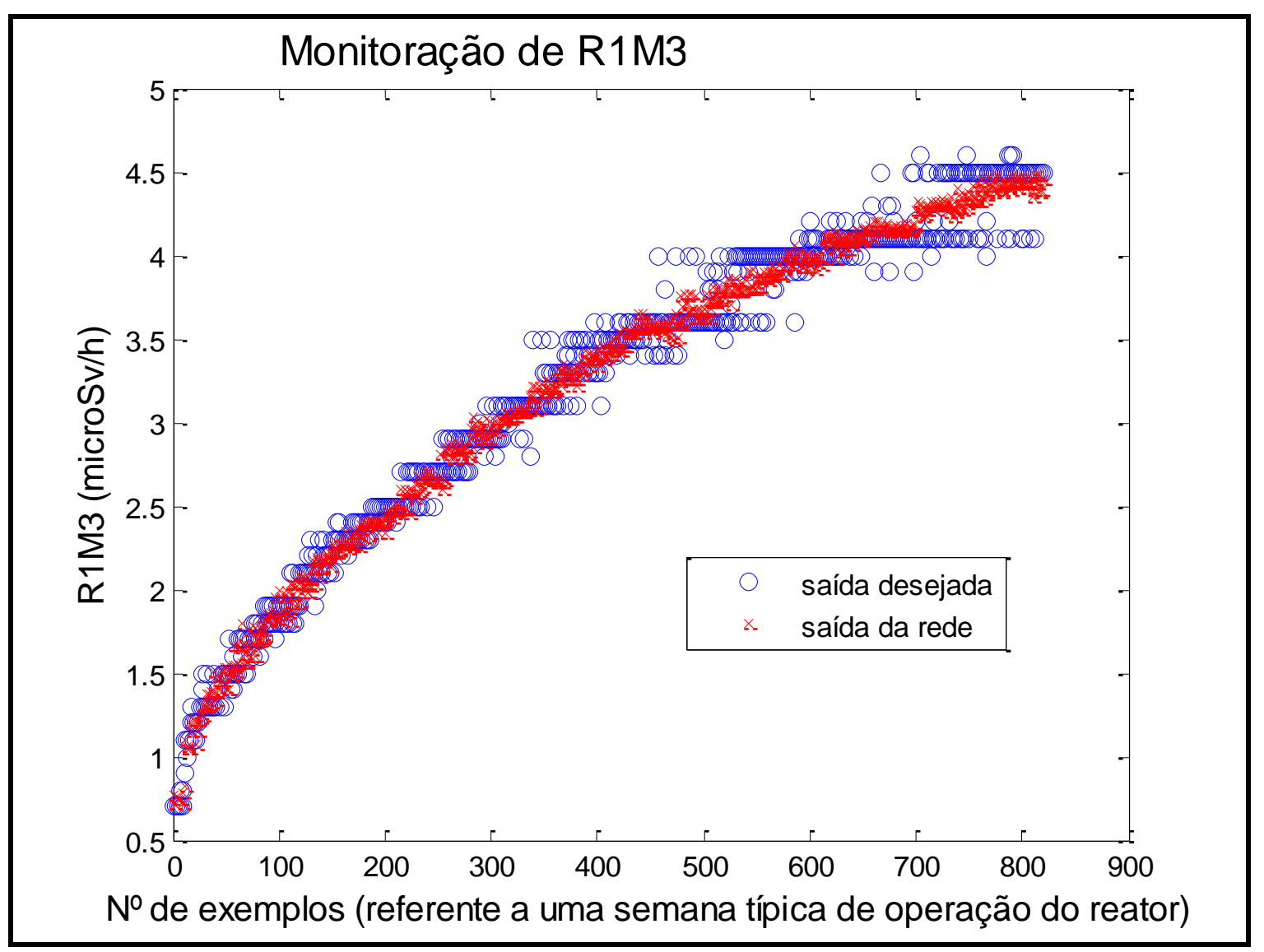

Figura 83. Saída desejada comparada à saída da rede com 10 neurônios na camada escondida

- Monitoração de R2M3

Ao realizar o pré-processamento através do estudo das variáveis desconsideradas pelo GMDH, verificou-se que para a variável R2M3 (modelo 5), as variáveis que tiveram uma relevância maior para o GMDH foram: Z1, R1M3, R8M3, R11M3 e T4. Essas variáveis foram utilizadas no treinamento das RNA, onde a rede com 8 neurônios na camada escondida apresentou o menor resíduo, cujo valor foi 2,6268 (Figura 84). A Figura 85 mostra a saída da rede em função da saída desejada com 8 neurônios na camada escondida.

Como pode ser observado na Figura a seguir, o uso de Seleção - GMDH apresentou os menores valores residuais. 


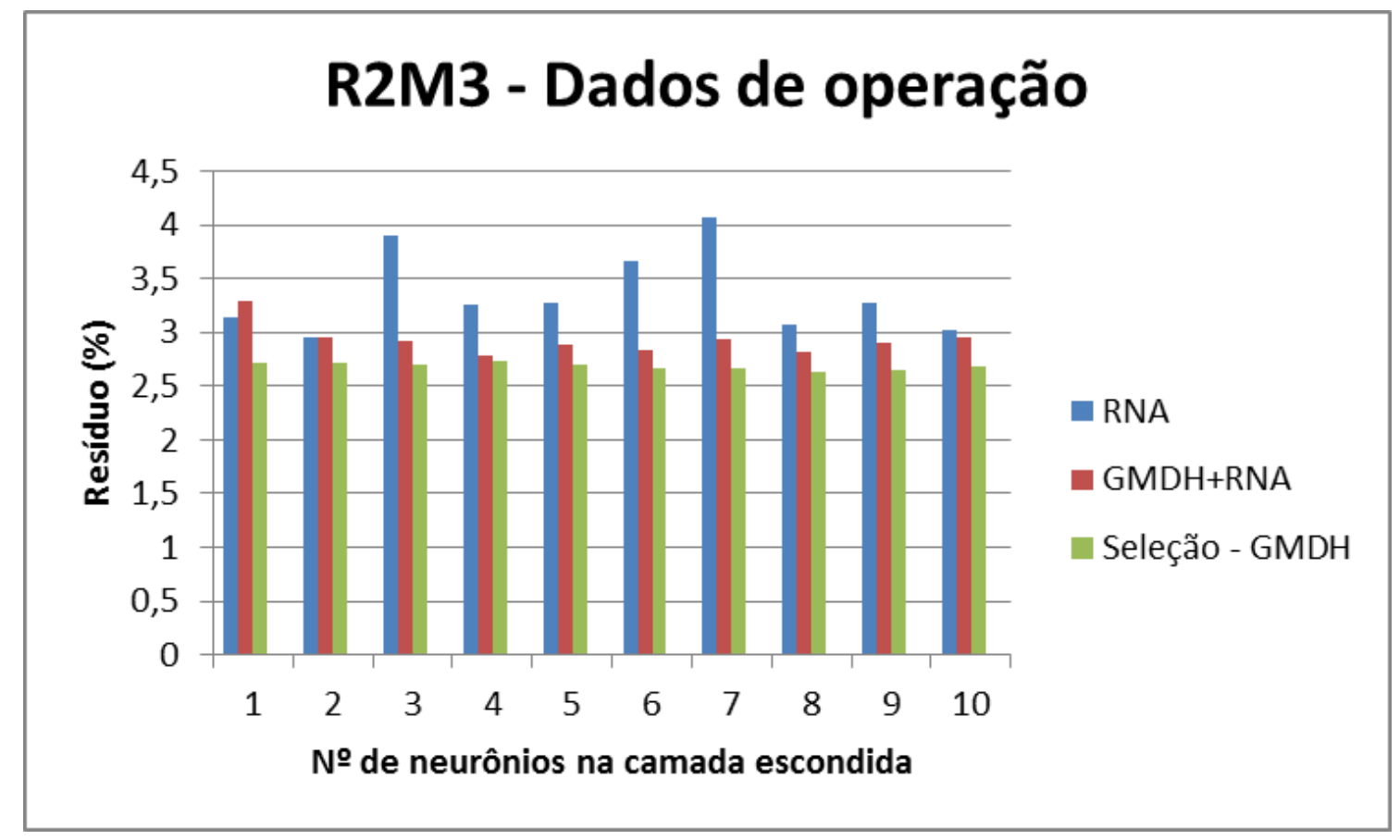

Figura 84. Monitoração de R2M3 - Comparação entre as metodologias

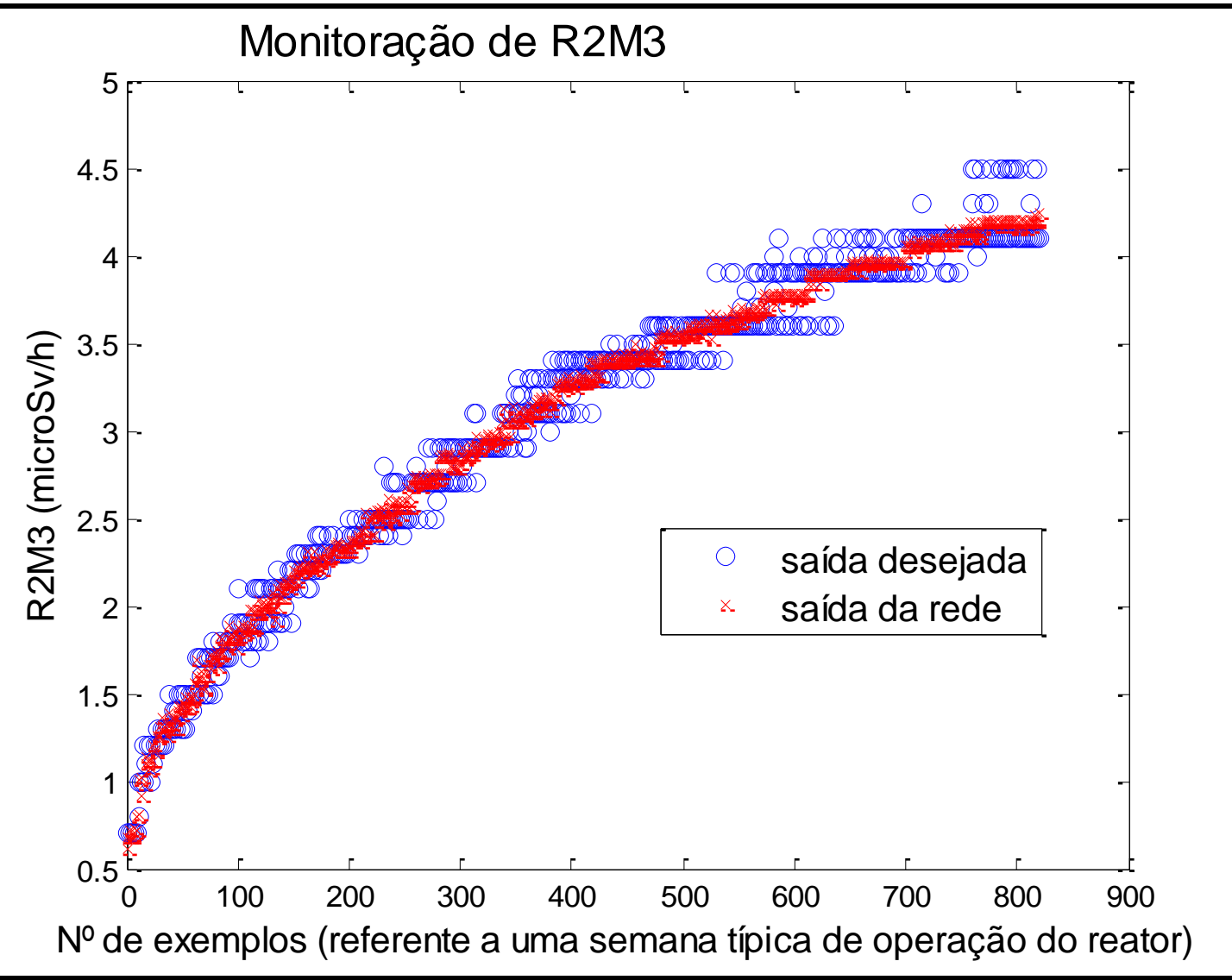

Figura 85. Saída desejada comparada à saída da rede com 8 neurônios na camada escondida 
- Monitoração de R3M3

Ao realizar o pré-processamento através do estudo das variáveis desconsideradas pelo GMDH, verificou-se que para a variável R3M3 (modelo 5), as variáveis que tiveram uma relevância maior para o GMDH foram: R1M3, R2M3, R8M3, R11M3 e T7. Essas variáveis foram utilizadas no treinamento das RNA, onde a rede com 8 neurônios na camada escondida apresentou o menor resíduo, cujo valor foi 2,8834 (Figura 86). A Figura 87 mostra a saída da rede em função da saída desejada com 8 neurônios na camada escondida.

Como pode ser observado na Figura a seguir, o uso de Seleção - GMDH apresentou os menores valores residuais.

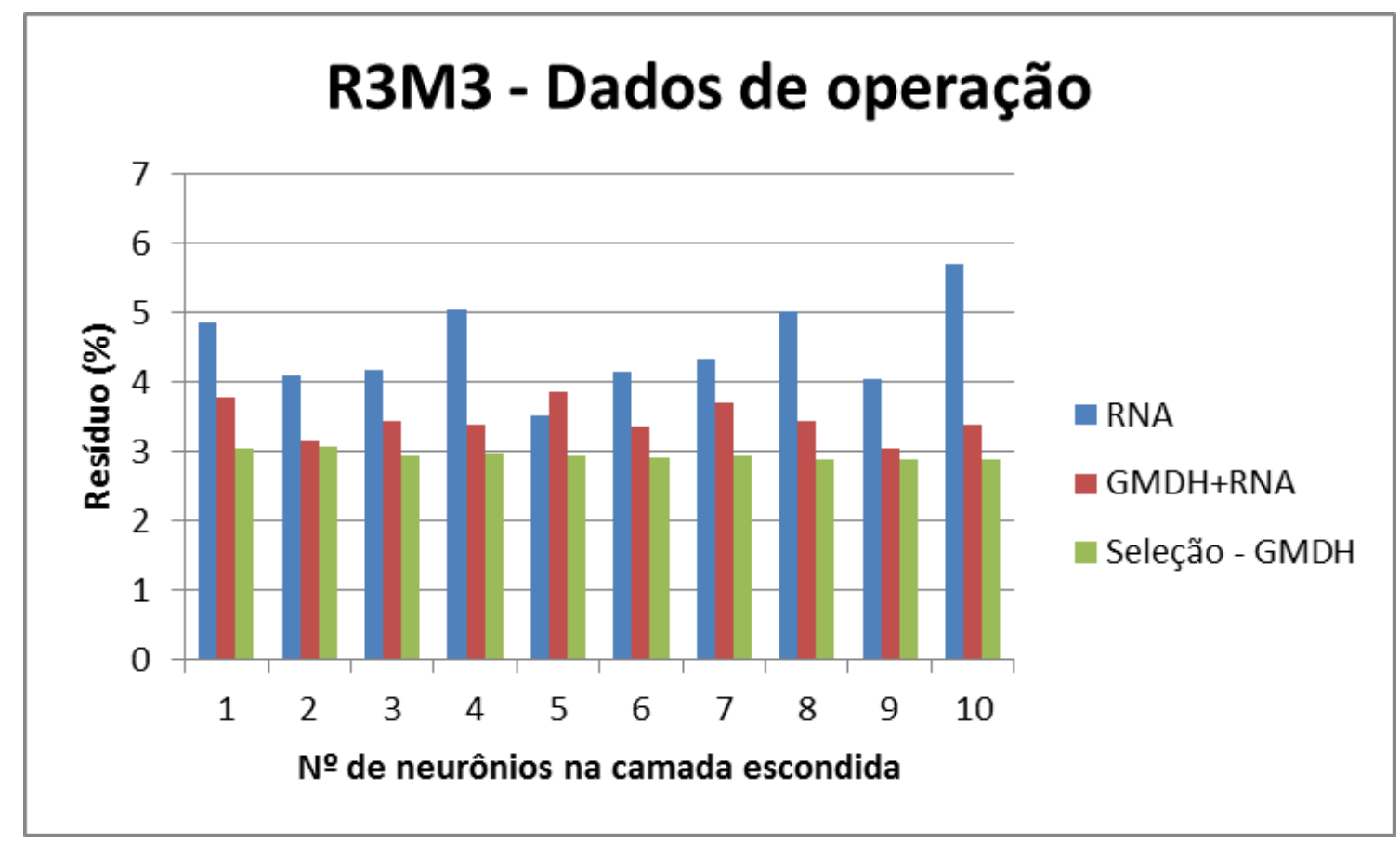

Figura 86. Monitoração de R3M3 - Comparação entre as metodologias 


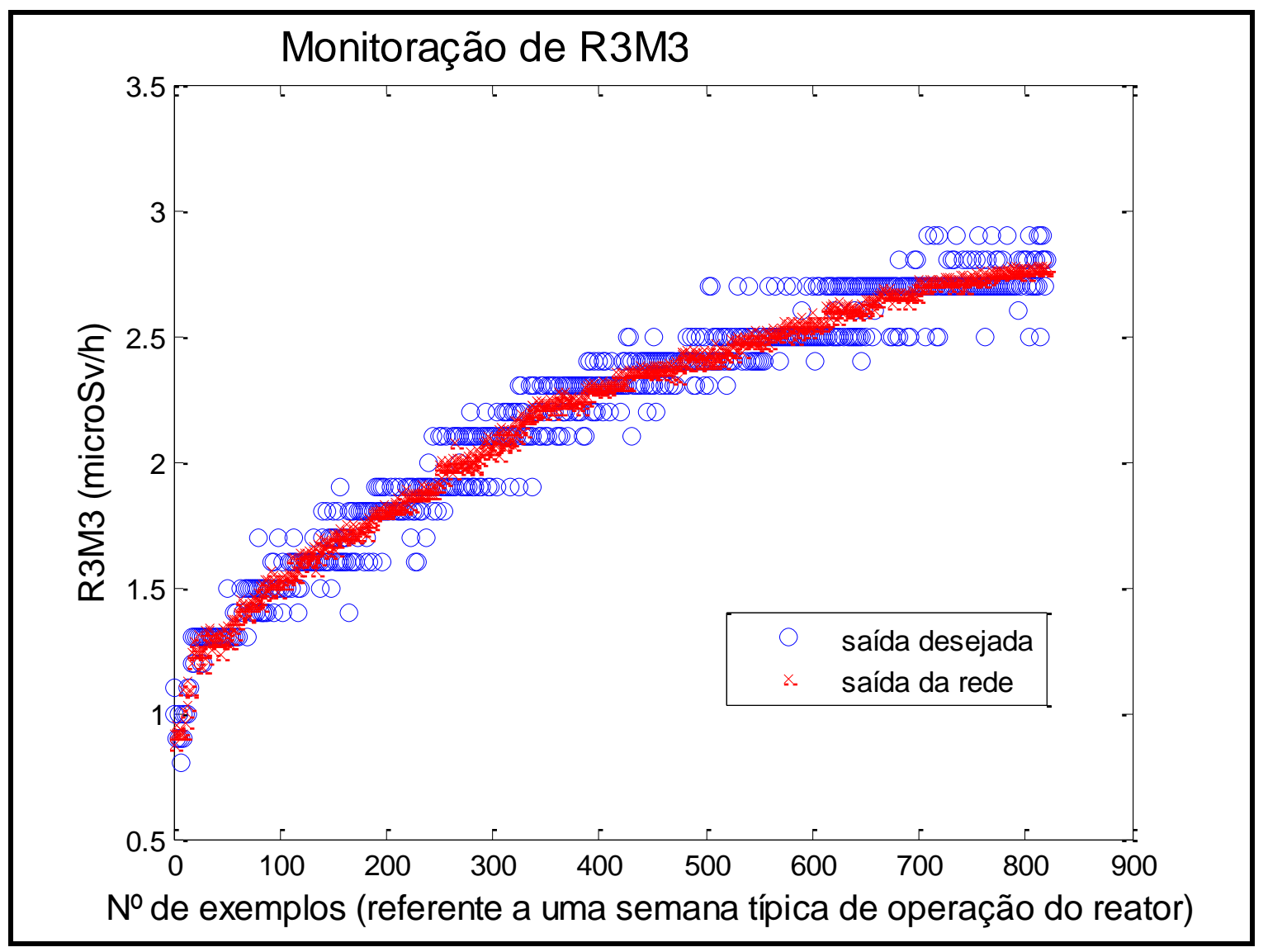

Figura 87. Saída desejada comparada à saída da rede com 8 neurônios na camada escondida

\section{- Monitoração de R7M3}

Ao realizar o pré-processamento através do estudo das variáveis desconsideradas pelo GMDH, verificou-se que para a variável R7M3 (modelo 5), as variáveis que tiveram uma relevância maior para o GMDH foram: Z2, N4, N7, N8, R8M3 e T8. Essas variáveis foram utilizadas no treinamento das RNA, onde a rede com 10 neurônios na camada escondida apresentou o menor resíduo, cujo valor foi 2,8065 (Figura 88). A Figura 89 mostra a saída da rede em função da saída desejada com 10 neurônios na camada escondida.

Como pode ser observado na Figura a seguir, o uso de Seleção - GMDH apresentou os menores valores residuais, na maioria dos casos simulados. 


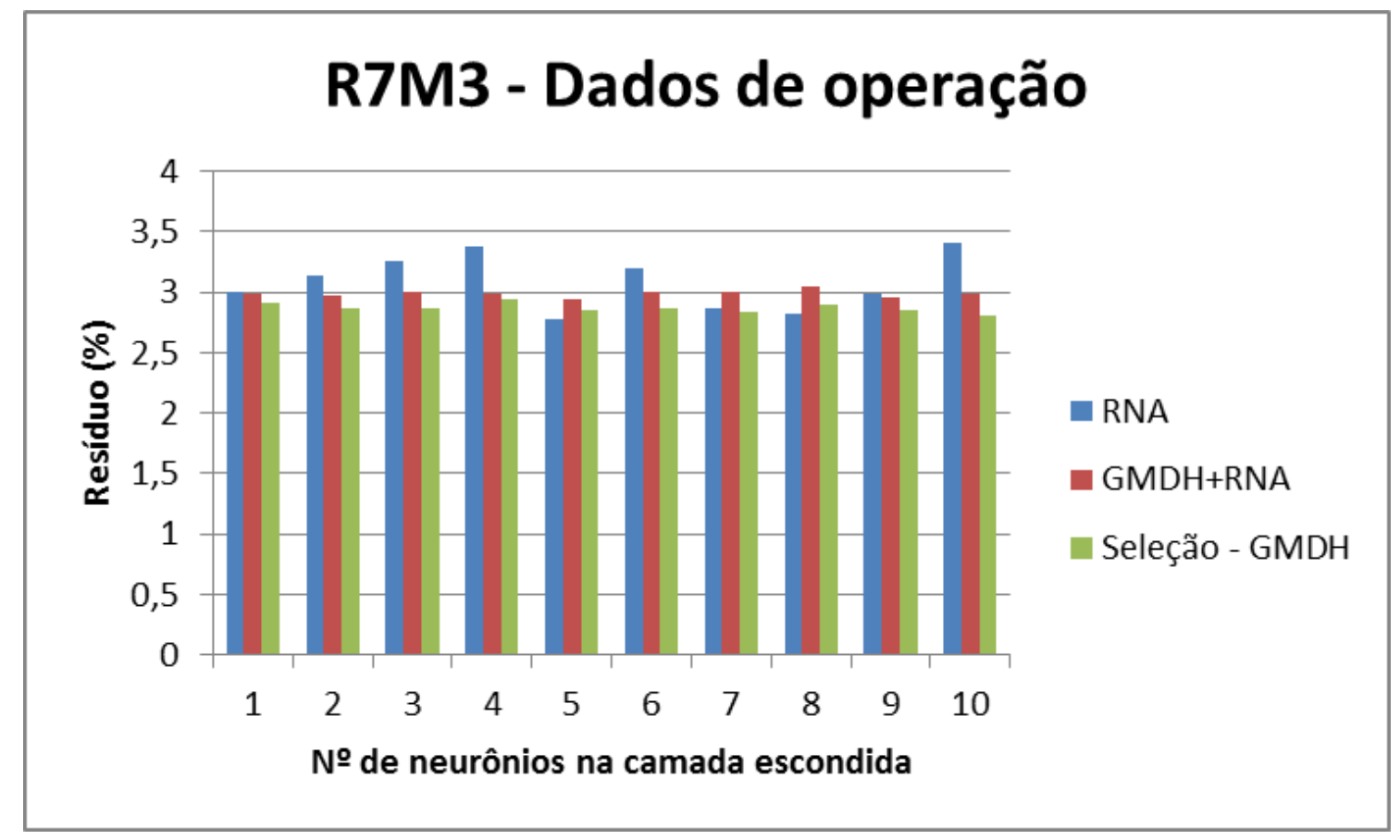

Figura 88. Monitoração de R7M3 - Comparação entre as metodologias

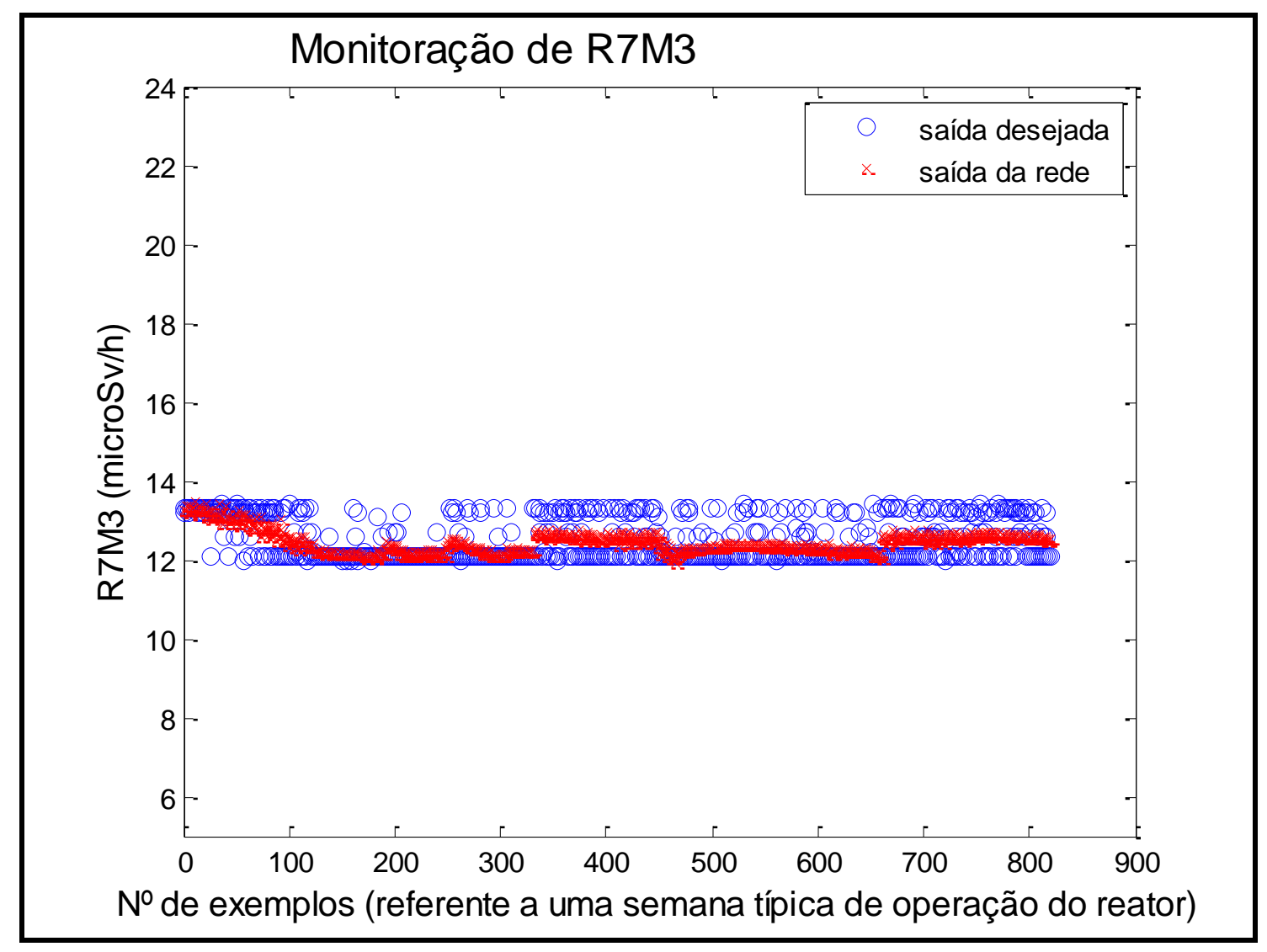

Figura 89. Saída desejada comparada à saída da rede com 10 neurônios na camada escondida 
- Monitoração de R8M3

Ao realizar o pré-processamento através do estudo das variáveis desconsideradas pelo GMDH, verificou-se que para a variável R8M3 (modelo 5), as variáveis que tiveram uma relevância maior para o GMDH foram: Z1, Z2, R1M3, R2M3 e R11M3. Essas variáveis foram utilizadas no treinamento das RNA, onde a rede com 10 neurônios na camada escondida apresentou o menor resíduo, cujo valor foi 1,9831 (Figura 90). A Figura 91 mostra a saída da rede em função da saída desejada com 10 neurônios na camada escondida.

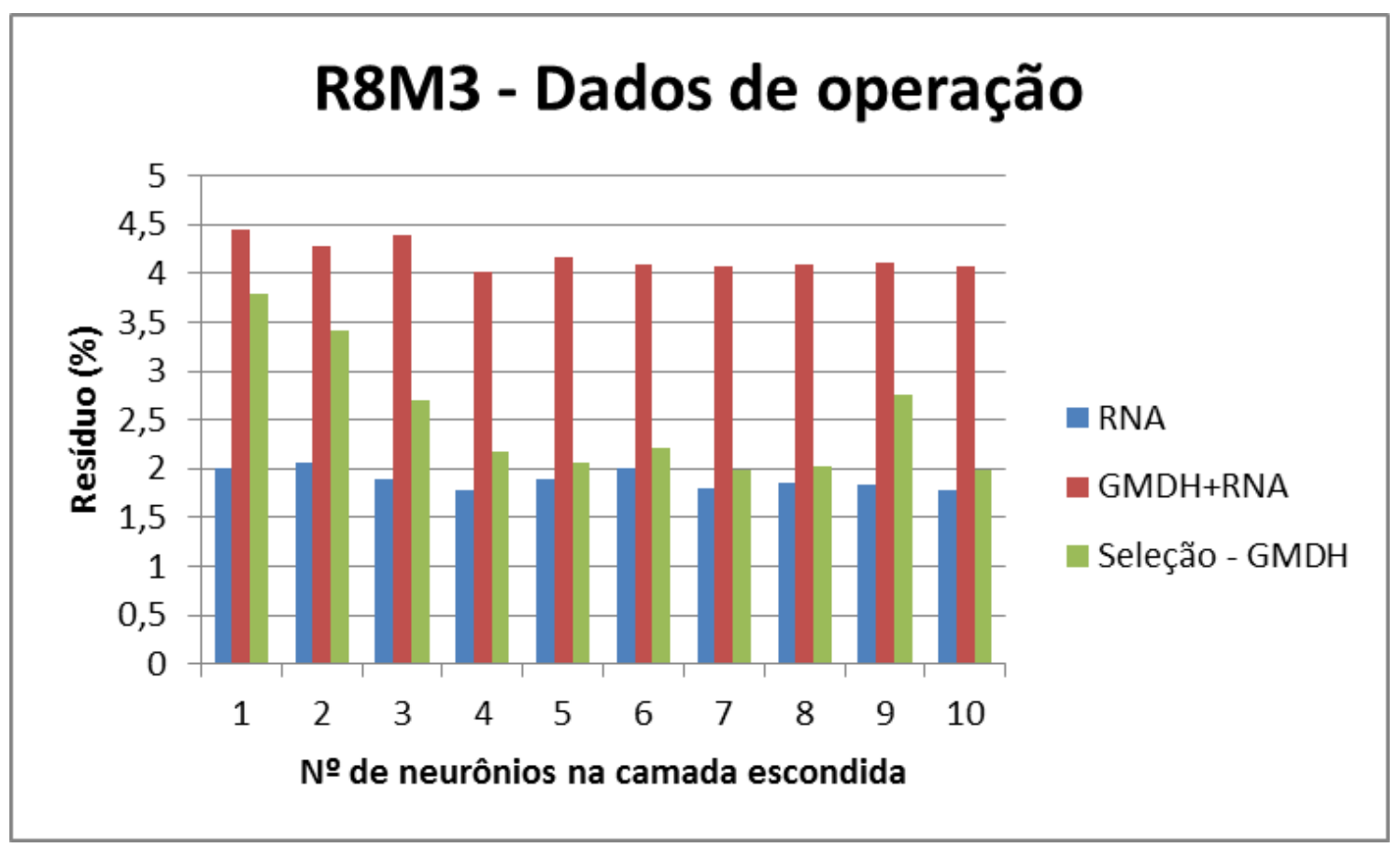

Figura 90. Monitoração de R8M3 - Comparação entre as metodologias

Como pode ser observado na Figura a seguir, o uso de RNA apresentou os menores valores residuais. 


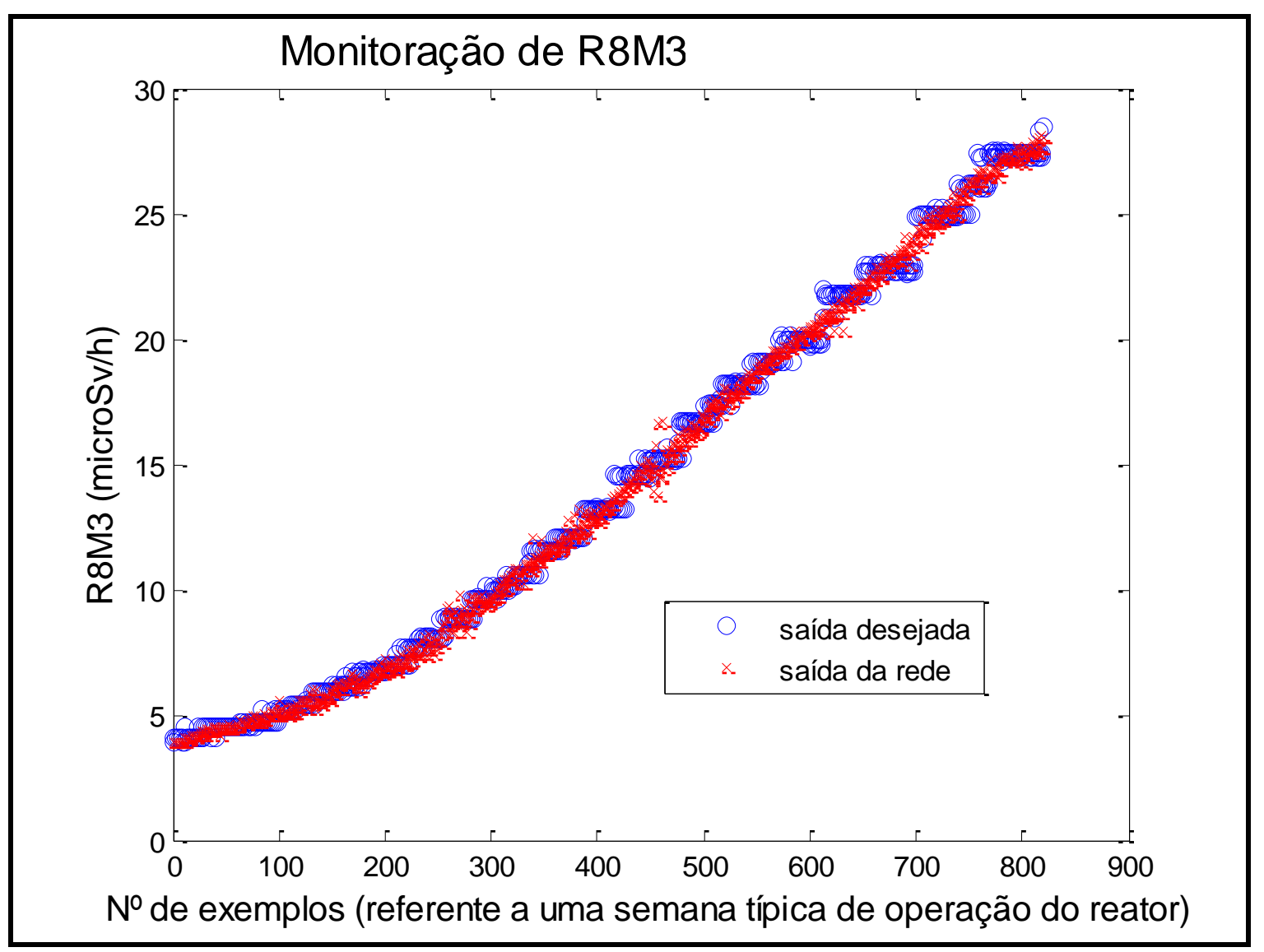

Figura 91. Saída desejada comparada à saída da rede com 10 neurônios na camada escondida

A Figura acima apresenta os resultados obtidos na monitoração de R8M3 usando Seleção - GMDH, porém o menor resíduo obtido foi através do uso da metodologia RNA sem pré-processamento.

\section{- Monitoração de R9M3}

Ao realizar o pré-processamento através do estudo das variáveis desconsideradas pelo GMDH, verificou-se que para a variável R9M3 (modelo 5), as variáveis que tiveram uma relevância maior para o GMDH foram: N3, N7 e T6. Essas variáveis foram utilizadas no treinamento das RNA, onde a rede com 3 neurônios na camada escondida apresentou o menor resíduo, cujo valor foi 1,8302 (Figura 92). A Figura 93 mostra a saída da rede em função da saída desejada com 3 neurônios na camada escondida.

Como pode ser observado na Figura a seguir, o uso de Seleção - GMDH apresentou os menores valores residuais, na maioria dos casos simulados. 


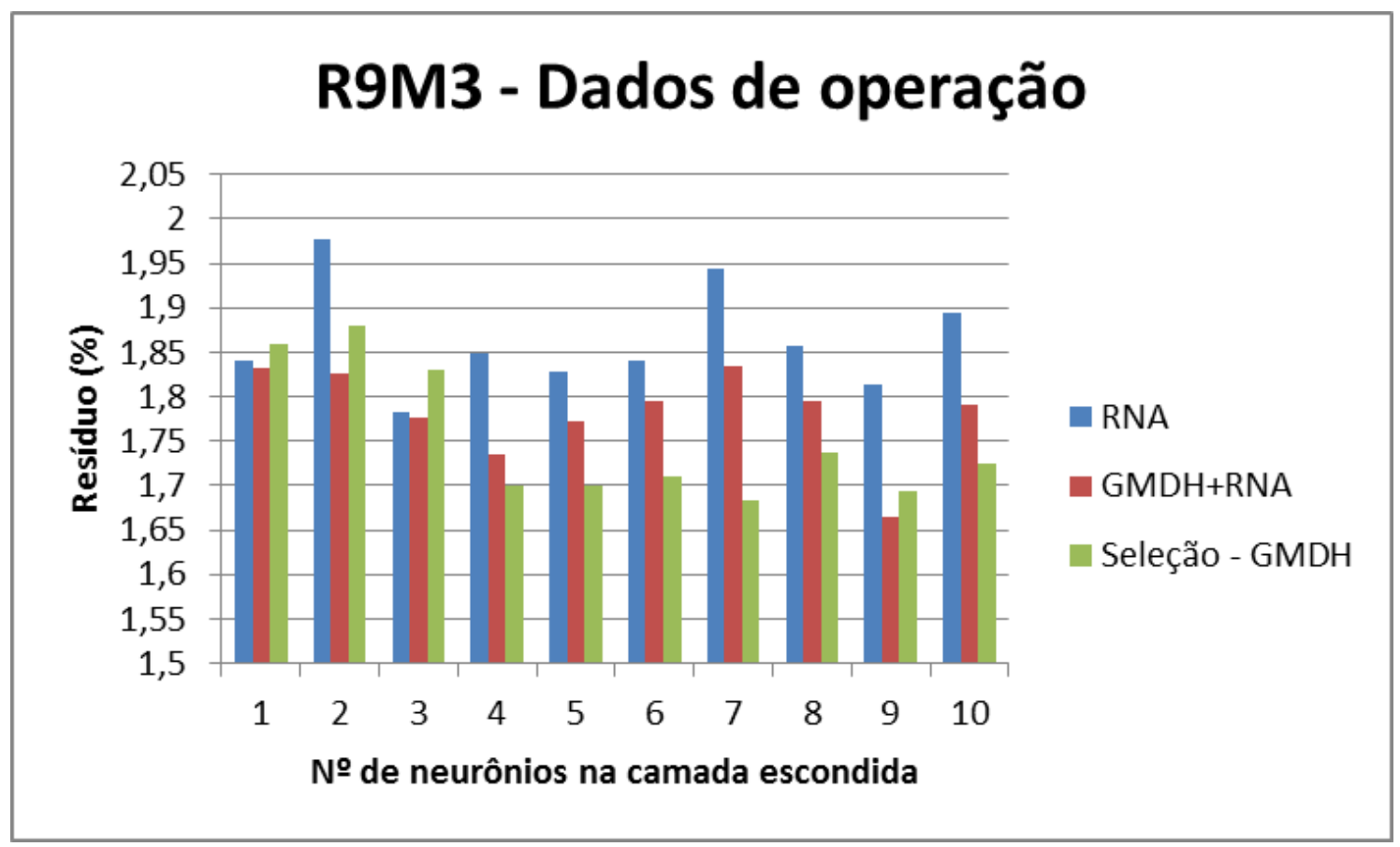

Figura 92. Monitoração de R9M3 - Comparação entre as metodologias

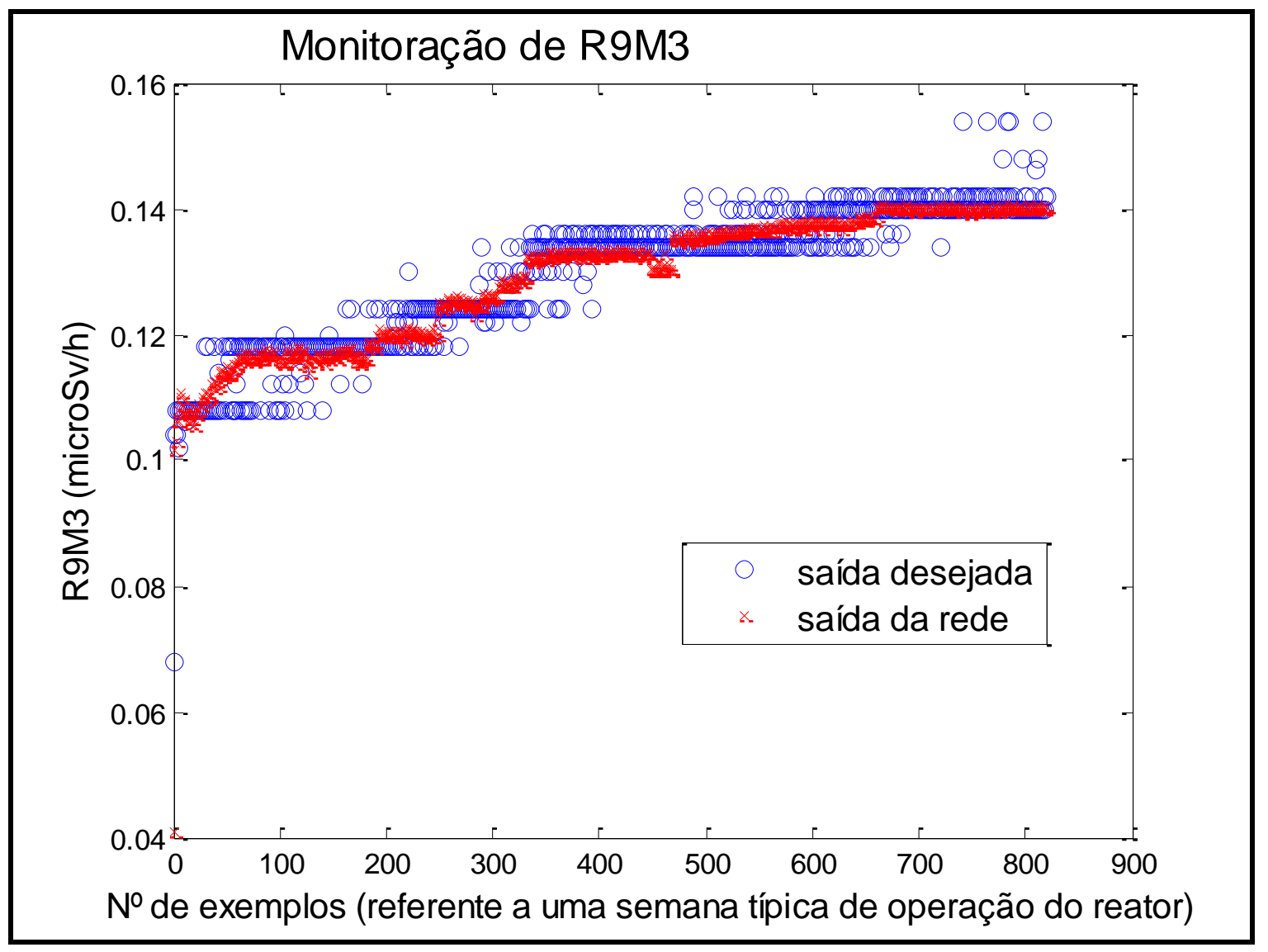

Figura 93. Saída desejada comparada à saída da rede com 3 neurônios na camada escondida 
- Monitoração de R10M3

Ao realizar o pré-processamento através do estudo das variáveis desconsideradas pelo GMDH, verificou-se que para a variável R10M3 (modelo 5), as variáveis que tiveram uma relevância maior para o GMDH foram: R11M3 e R12M3. Essas variáveis foram utilizadas no treinamento das RNA, onde a rede com 8 neurônios na camada escondida apresentou o menor resíduo, cujo valor foi 3,1599 (Figura 94). A Figura 95 mostra a saída da rede em função da saída desejada com 8 neurônios na camada escondida.

Como pode ser observado na Figura a seguir, o uso de Seleção - GMDH apresentou os menores valores residuais, na maioria dos casos simulados.

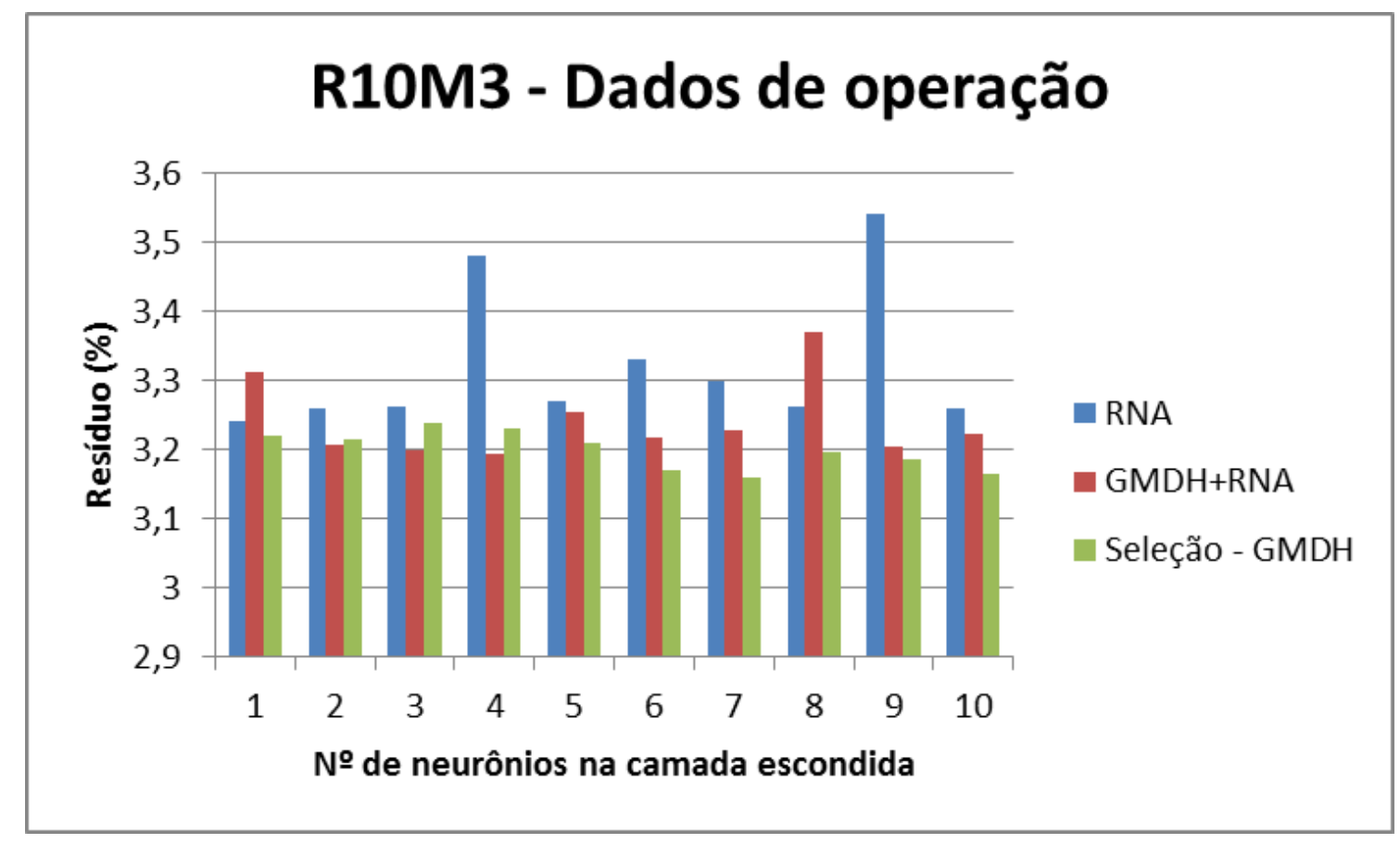

Figura 94. Monitoração de R10M3 - Comparação entre as metodologias 


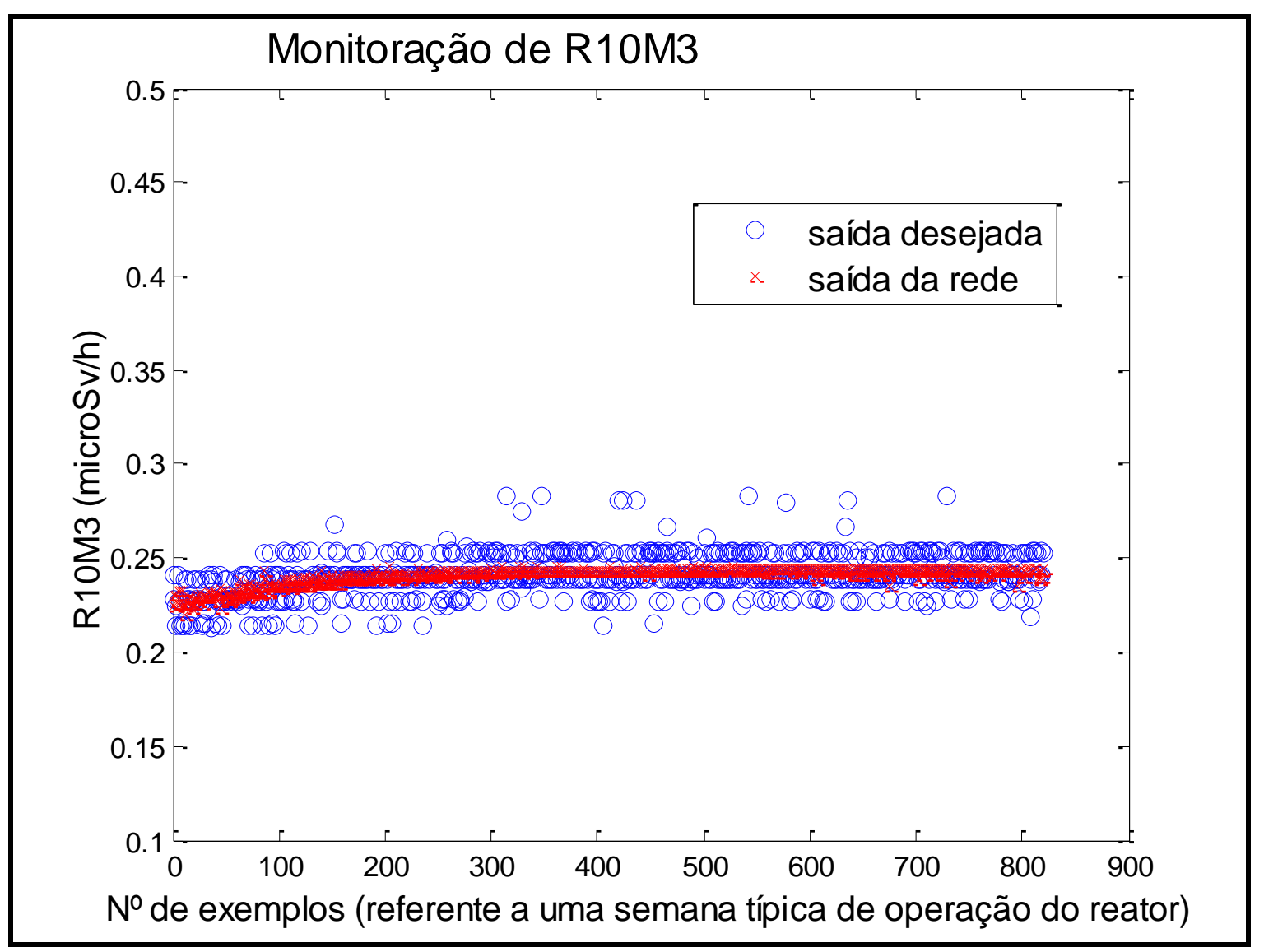

Figura 95. Saída desejada comparada à saída da rede com 8 neurônios na camada escondida

- Monitoração de R11M3

Ao realizar o pré-processamento através do estudo das variáveis desconsideradas pelo GMDH, verificou-se que para a variável R11M3 (modelo 5), as variáveis que tiveram uma relevância maior para o GMDH foram: Z1, Z4, R1M3, R2M3, R8M3, T1 e T6. Essas variáveis foram utilizadas no treinamento das RNA, onde a rede com 10 neurônios na camada escondida apresentou o menor resíduo, cujo valor foi 2,3390 (Figura 96). A Figura 97 mostra a saída da rede em função da saída desejada com 10 neurônios na camada escondida.

Como pode ser observado na Figura a seguir, o uso de Seleção - GMDH apresentou os menores valores residuais, na maioria dos casos simulados. 




Figura 96. Monitoração de R11M3 - Comparação entre as metodologias

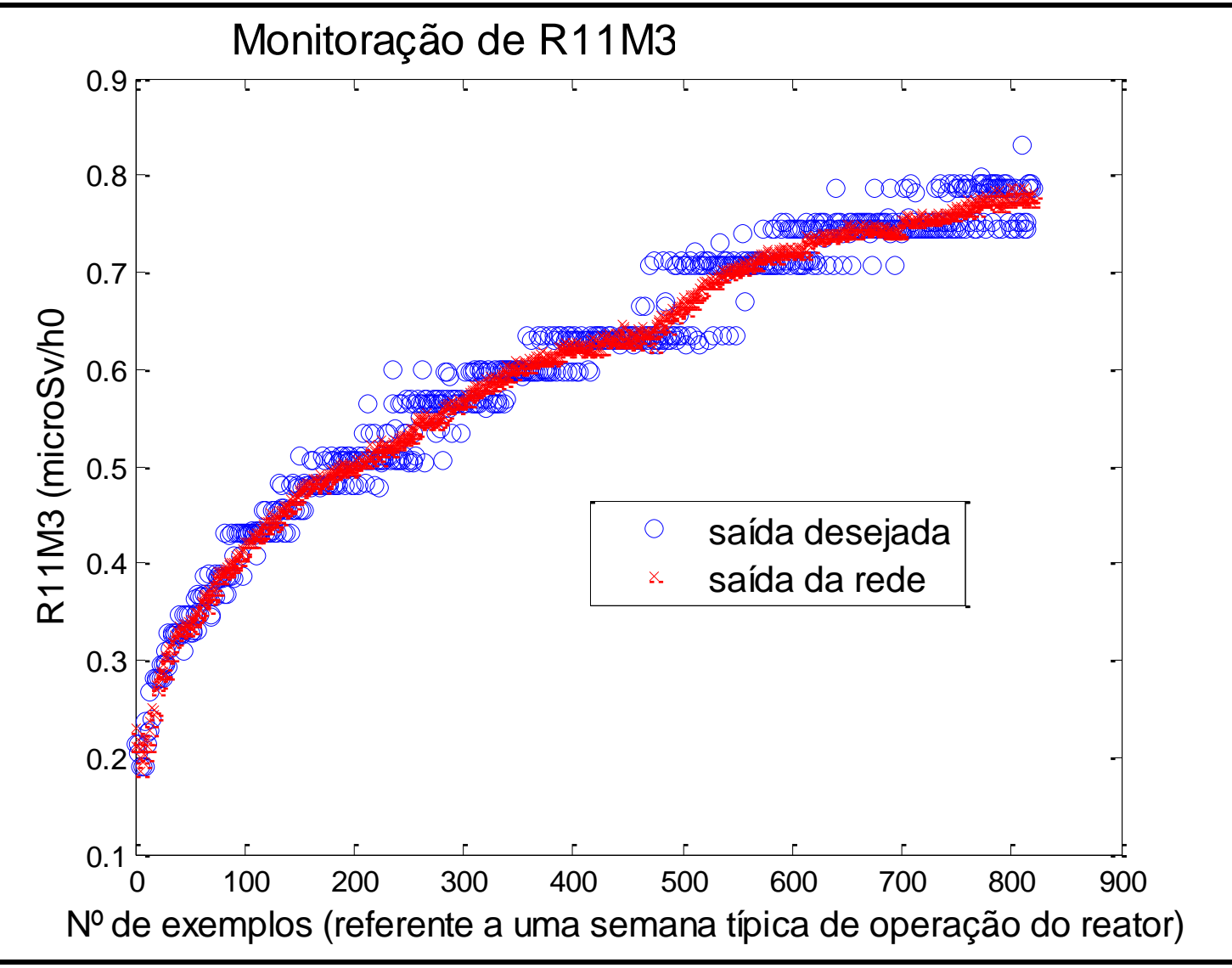

Figura 97. Saída desejada comparada à saída da rede com 10 neurônios na camada escondida 
- Monitoração de R12M3

Ao realizar o pré-processamento através do estudo das variáveis desconsideradas pelo GMDH, verificou-se que para a variável R12M3 (modelo 5), as variáveis que tiveram uma relevância maior para o GMDH foram: Z1, R8M3, R11M3, T1 e T6. Essas variáveis foram utilizadas no treinamento das RNA, onde a rede com 10 neurônios na camada escondida apresentou o menor resíduo, cujo valor foi 5,0551 (Figura 98). A Figura 99 mostra a saída da rede em função da saída desejada com 10 neurônios na camada escondida.

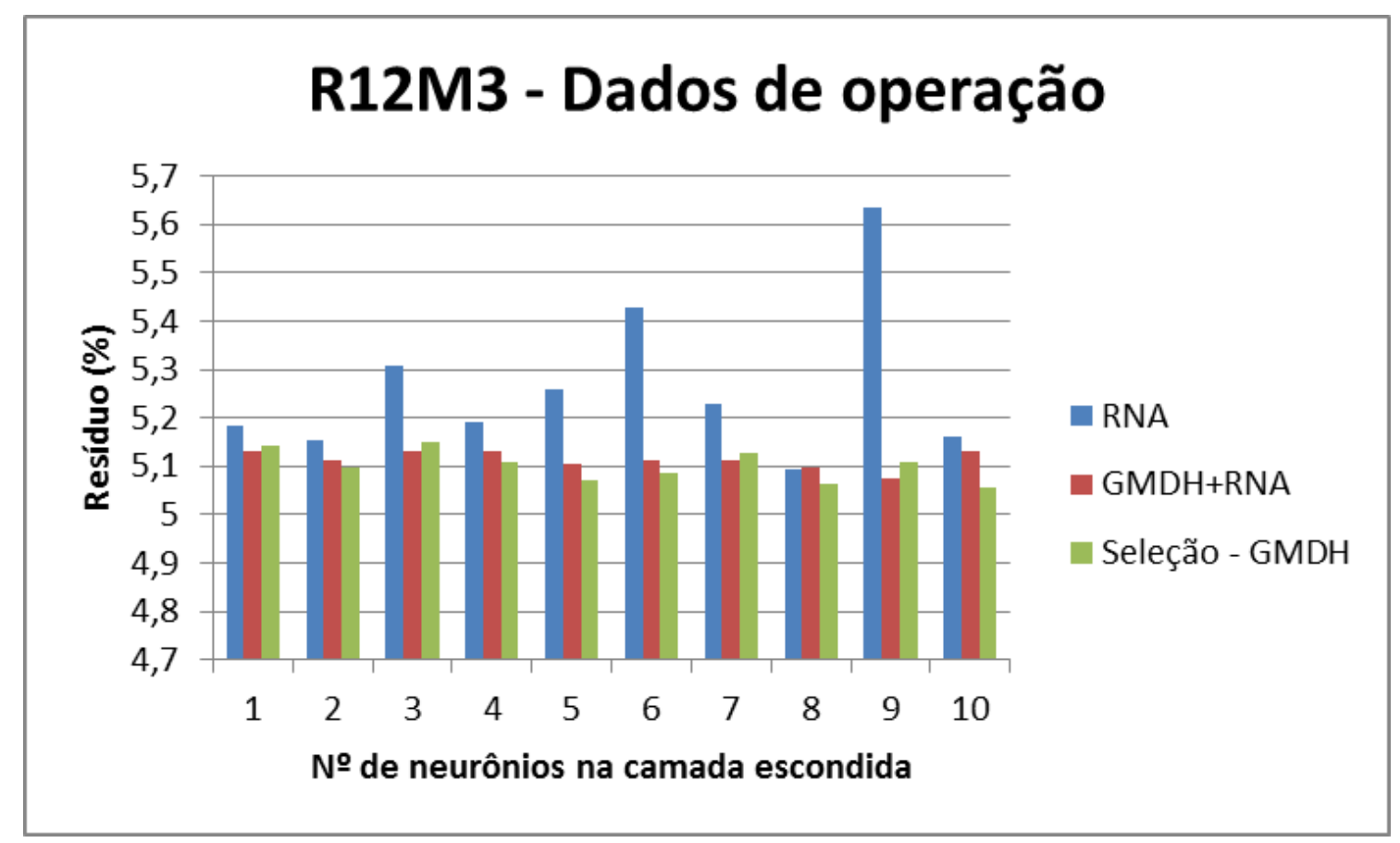

Figura 98. Monitoração de R12M3 - Comparação entre as metodologias

Como pode ser observado na Figura a seguir, o uso de Seleção - GMDH apresentou os menores valores residuais, na maioria dos casos simulados. 


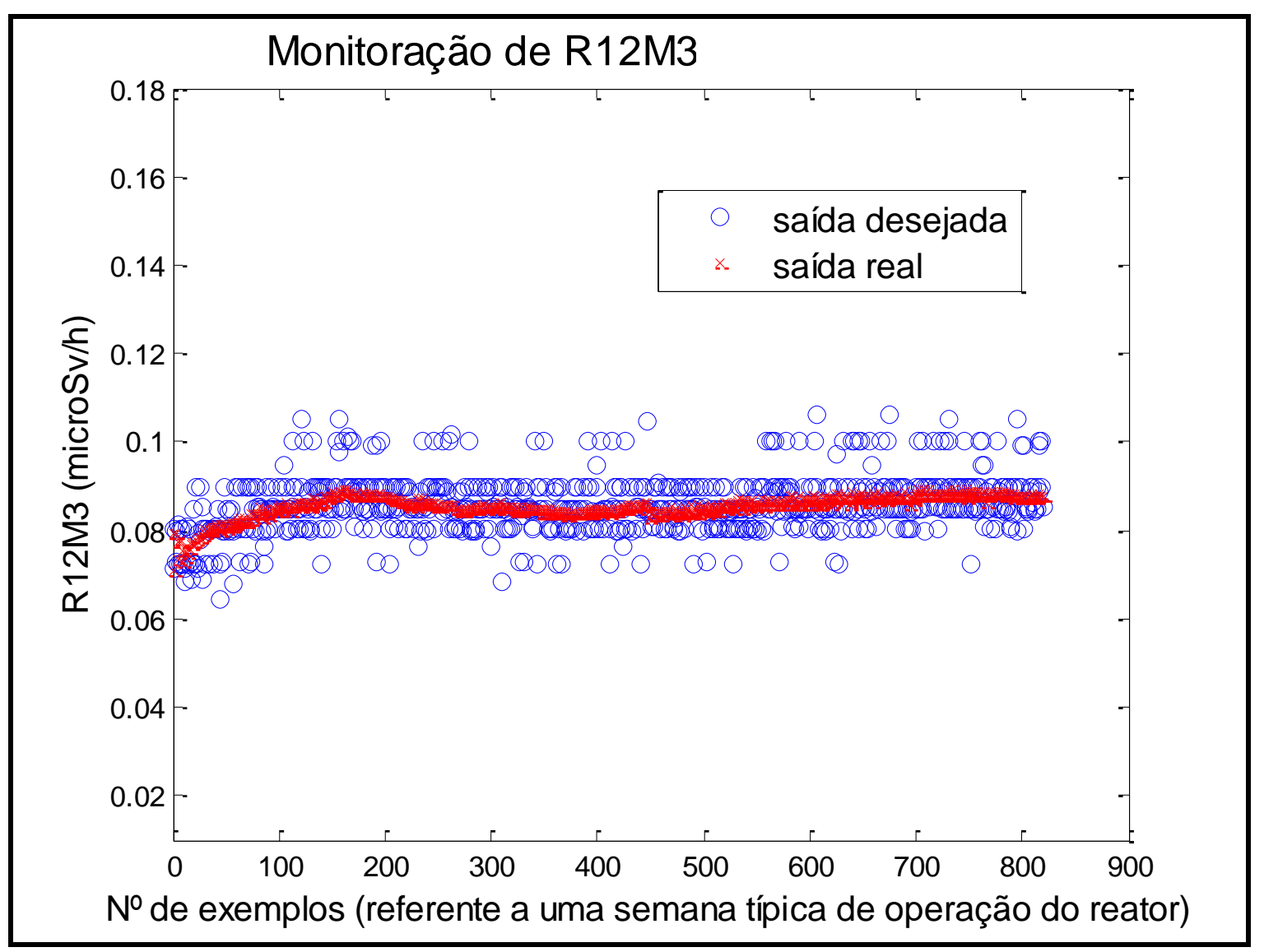

Figura 99. Saída desejada comparada à saída da rede com 10 neurônios na camada escondida

- Monitoração de R14M3

Ao realizar o pré-processamento através do estudo das variáveis desconsideradas pelo GMDH, verificou-se que para a variável R14M3 (modelo 5), as variáveis que tiveram uma relevância maior para o GMDH foram: R8M3, R11M3 e T1. Essas variáveis foram utilizadas no treinamento das RNA, onde a rede com 8 neurônios na camada escondida apresentou o menor resíduo, cujo valor foi 6,0936 (Figura 100). A Figura 101 mostra a saída da rede em função da saída desejada com 8 neurônios na camada escondida.

Como pode ser observado na Figura a seguir, o uso de Seleção - GMDH apresentou os menores valores residuais, na maioria dos casos simulados. 


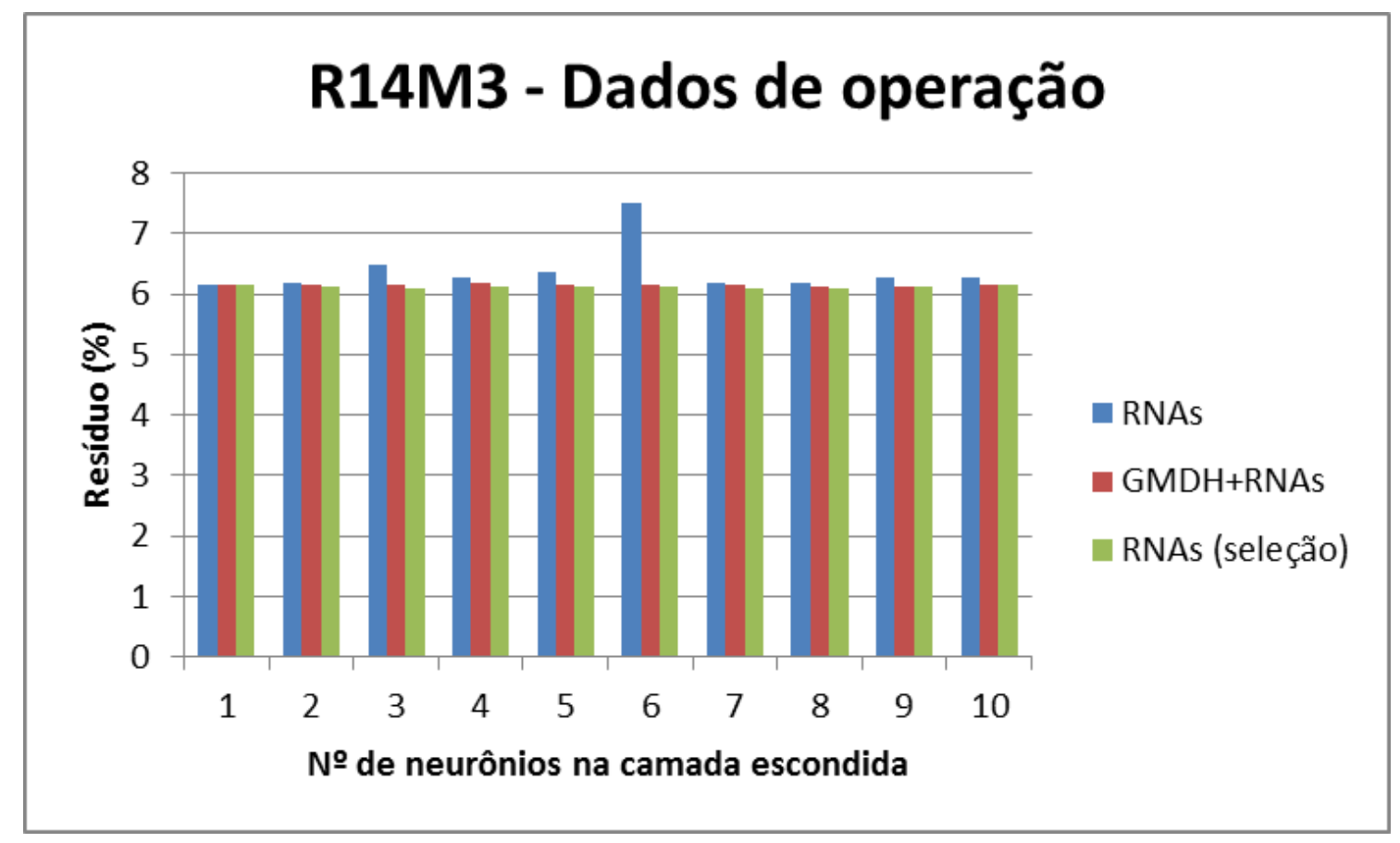

Figura 100. Monitoração de R14M3 - Comparação entre as metodologias

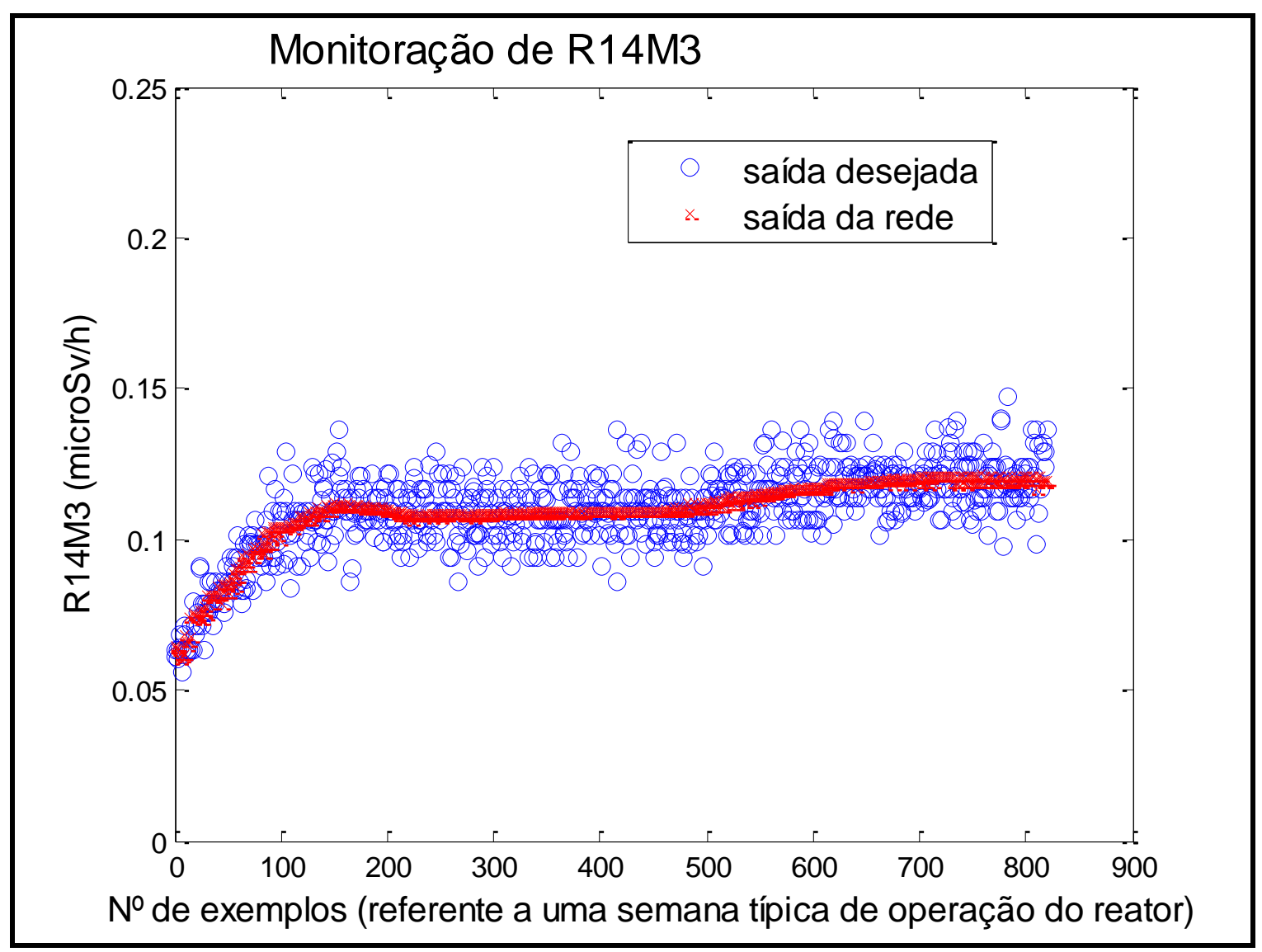

Figura 101. Saída desejada comparada à saída da rede com 8 neurônios na camada escondida 
- Monitoração de Z1

Ao realizar o pré-processamento através do estudo das variáveis desconsideradas pelo GMDH, verificou-se que para a variável Z1 (modelo 5), as variáveis que tiveram uma relevância maior para o GMDH foram: Z2, R2M3, R8M3 e R11M3. Essas variáveis foram utilizadas no treinamento das RNA, onde a rede com 9 neurônios na camada escondida apresentou o menor resíduo, cujo valor foi 0,8279 (Figura 102). A Figura 103 mostra a saída da rede em função da saída desejada com 9 neurônios na camada escondida.

Como pode ser observado na Figura a seguir, o uso de RNA apresentou os menores valores residuais.

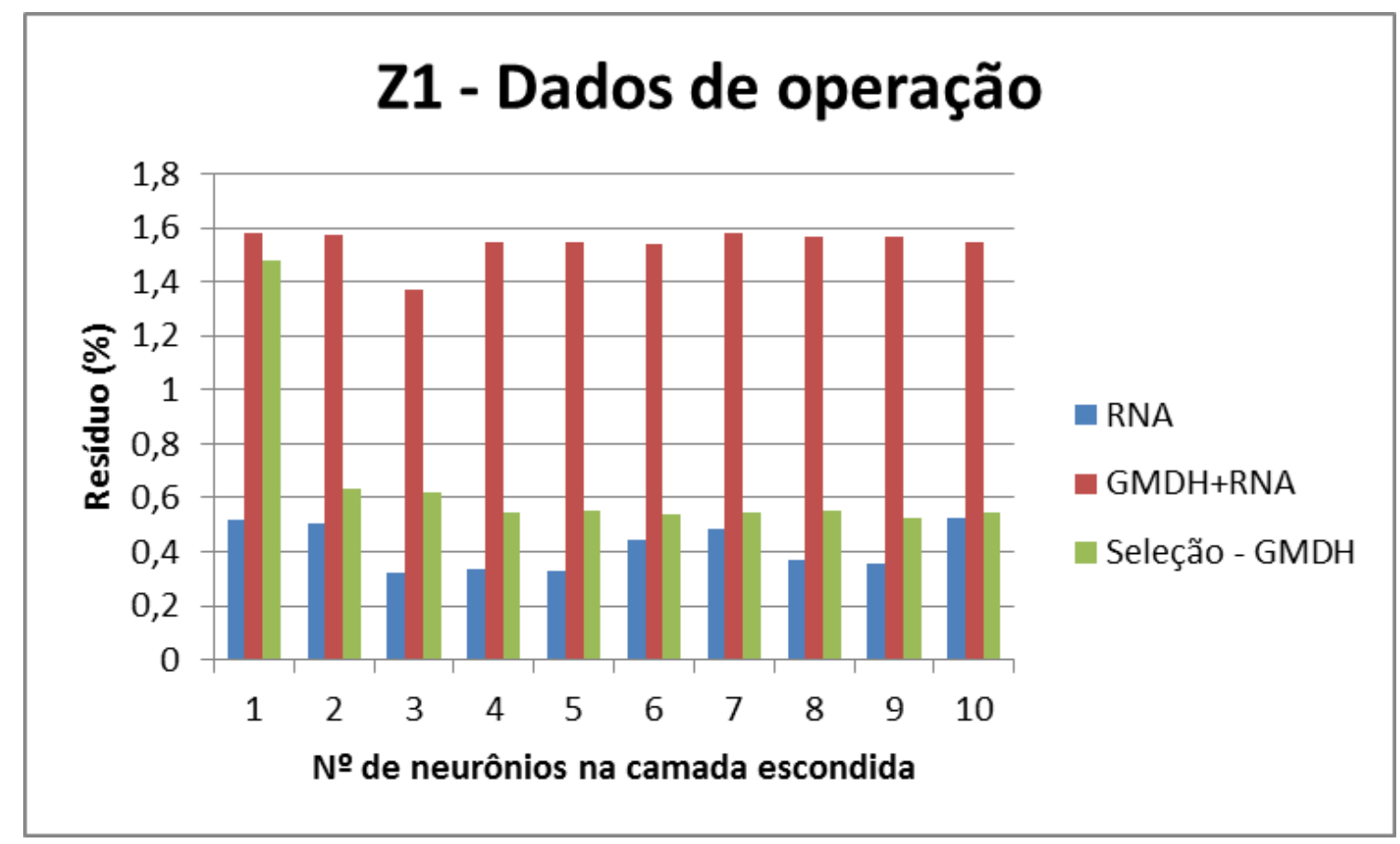

Figura 102. Monitoração de Z1 - Comparação entre as metodologias 


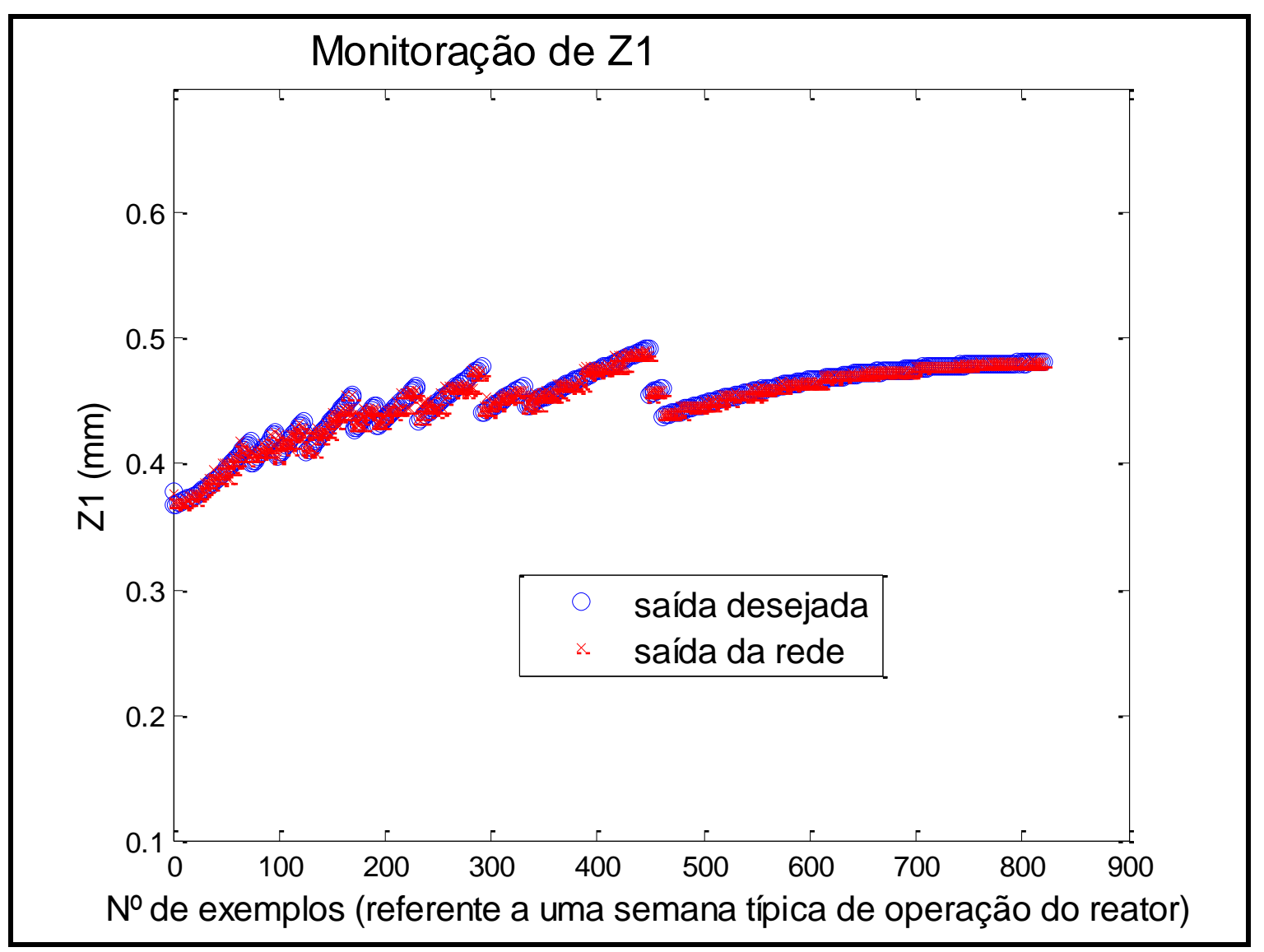

Figura 103. Saída desejada comparada à saída da rede com 9 neurônios na camada escondida

A Figura acima apresenta os resultados na monitoração de Z1 usando Seleção GMDH, porém o menor resíduo obtido foi através de RNA sem a etapa de préprocessamento.

\section{- Monitoração de Z2}

Ao realizar o pré-processamento através do estudo das variáveis desconsideradas pelo GMDH, verificou-se que para a variável Z2 (modelo 5), as variáveis que tiveram uma relevância maior para o GMDH foram: Z1 e Z3. Essas variáveis foram utilizadas no treinamento das RNA, onde a rede com 8 neurônios na camada escondida apresentou o menor resíduo, cujo valor foi 0,1053 (Figura 104). A Figura 105 mostra a saída da rede em função da saída desejada com 8 neurônios na camada escondida.

Como pode ser observado na Figura a seguir, o uso de Seleção - GMDH apresentou os menores valores residuais, na maioria dos casos simulados. 


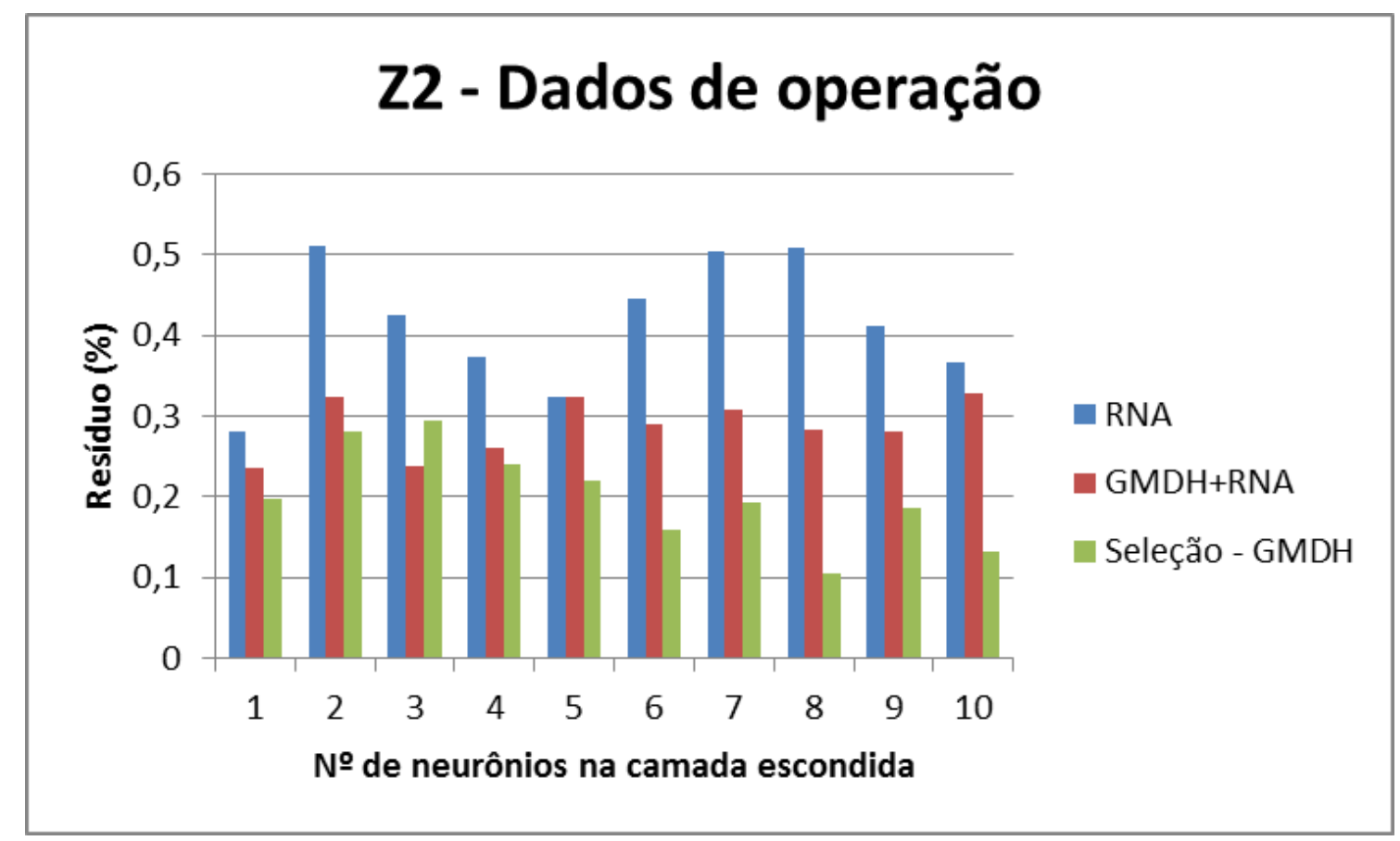

Figura 104. Monitoração de Z2 - Comparação entre as metodologias

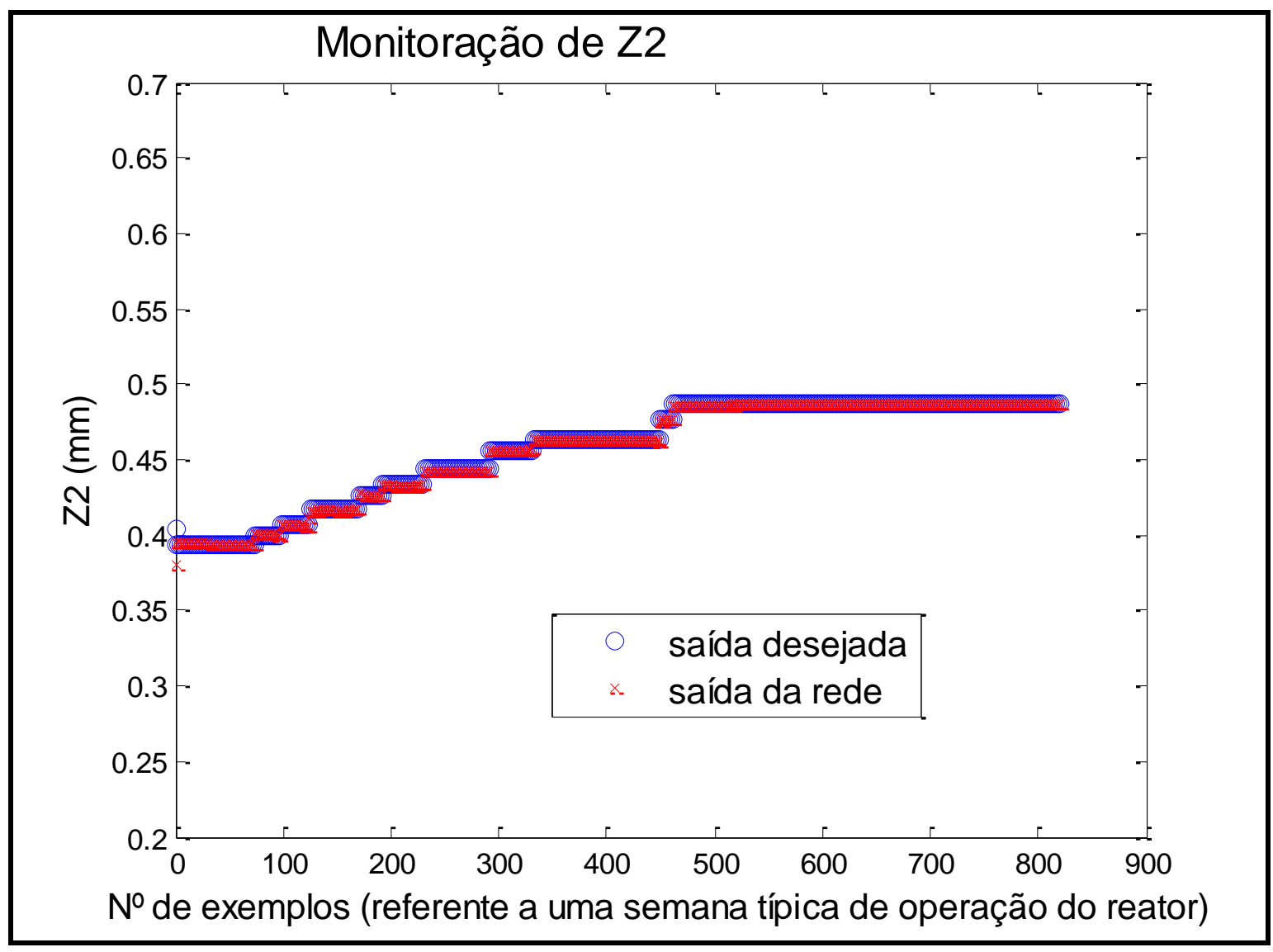

Figura 105. Saída desejada comparada à saída da rede com 8 neurônios na camada escondida 
- Monitoração de Z3

Ao realizar o pré-processamento através do estudo das variáveis desconsideradas pelo GMDH, verificou-se que para a variável Z3 (modelo 5), as variáveis que tiveram uma relevância maior para o GMDH foram: Z1 e Z4. Essas variáveis foram utilizadas no treinamento das RNA, onde a rede com 9 neurônios na camada escondida apresentou o menor resíduo, cujo valor foi 0,0019 (Figura 106). A Figura 107 mostra a saída da rede em função da saída desejada com 9 neurônios na camada escondida.

Como pode ser observado na Figura a seguir, o uso de Seleção - GMDH apresentou os menores valores residuais.

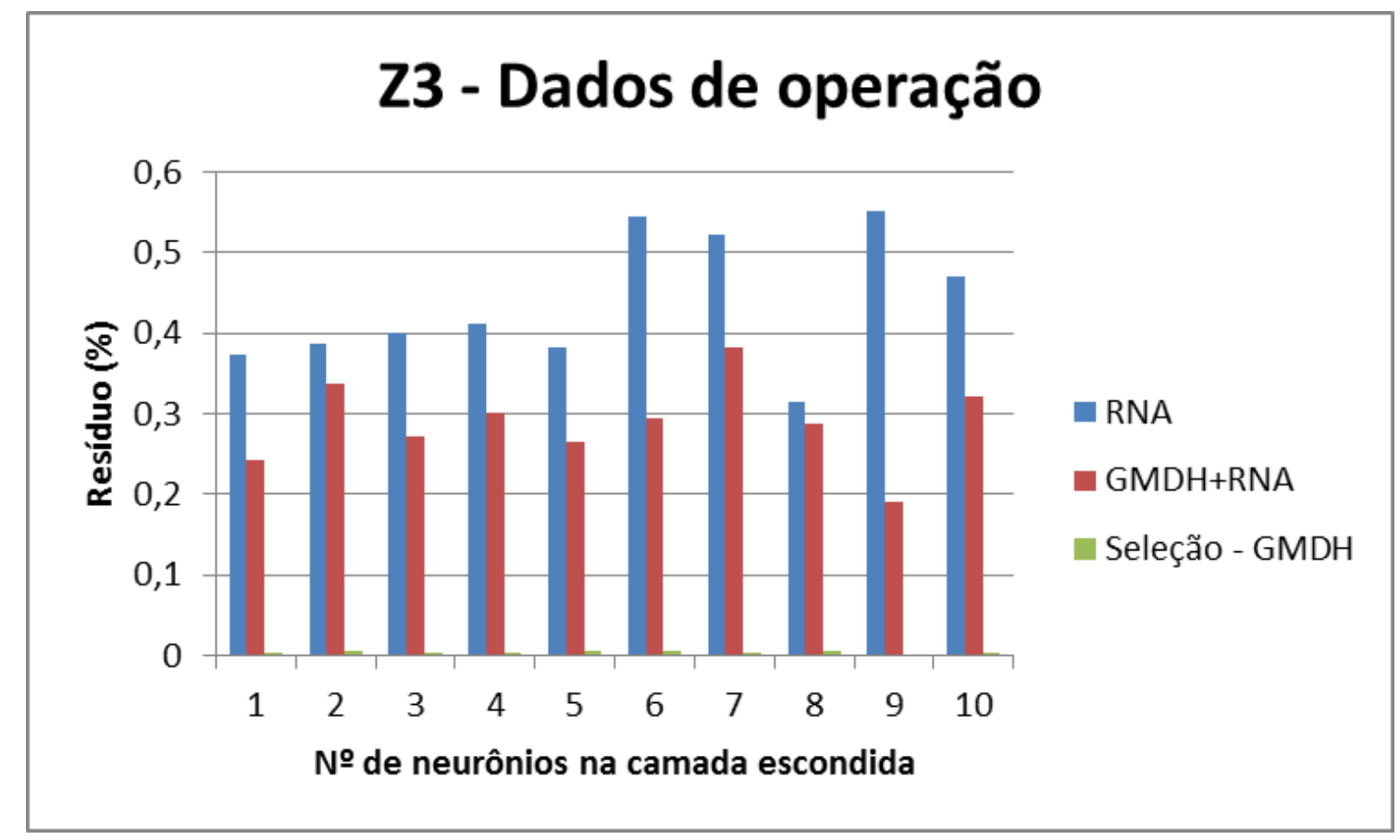

Figura 106. Monitoração de Z3 - Comparação entre as metodologias 


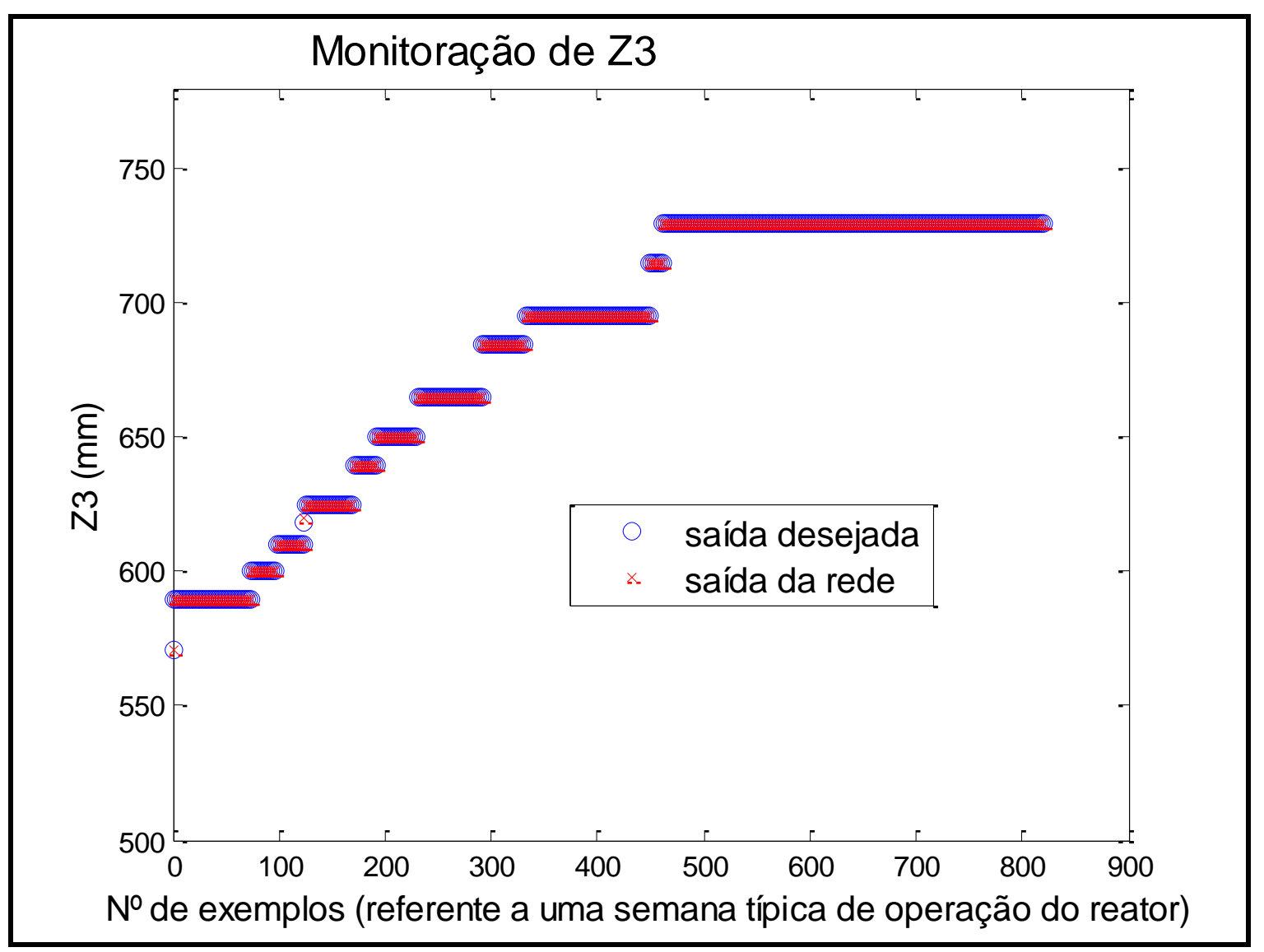

Figura 107. Saída desejada comparada à saída da rede com 9 neurônios na camada escondida

\section{- Monitoração de Z4}

Ao realizar o pré-processamento através do estudo das variáveis desconsideradas pelo GMDH, verificou-se que para a variável Z4 (modelo 5), as variáveis que tiveram uma relevância maior para o GMDH foram Z1 e Z3. Essas variáveis foram utilizadas no treinamento das RNA, onde a rede com 10 neurônios na camada escondida apresentou o menor resíduo, cujo valor foi 0,0036 (Figura 108). A Figura 109 mostra a saída da rede em função da saída desejada com 10 neurônios na camada escondida. Como pode ser observado na Figura a seguir, o uso de Seleção - GMDH apresentou os menores valores residuais. 


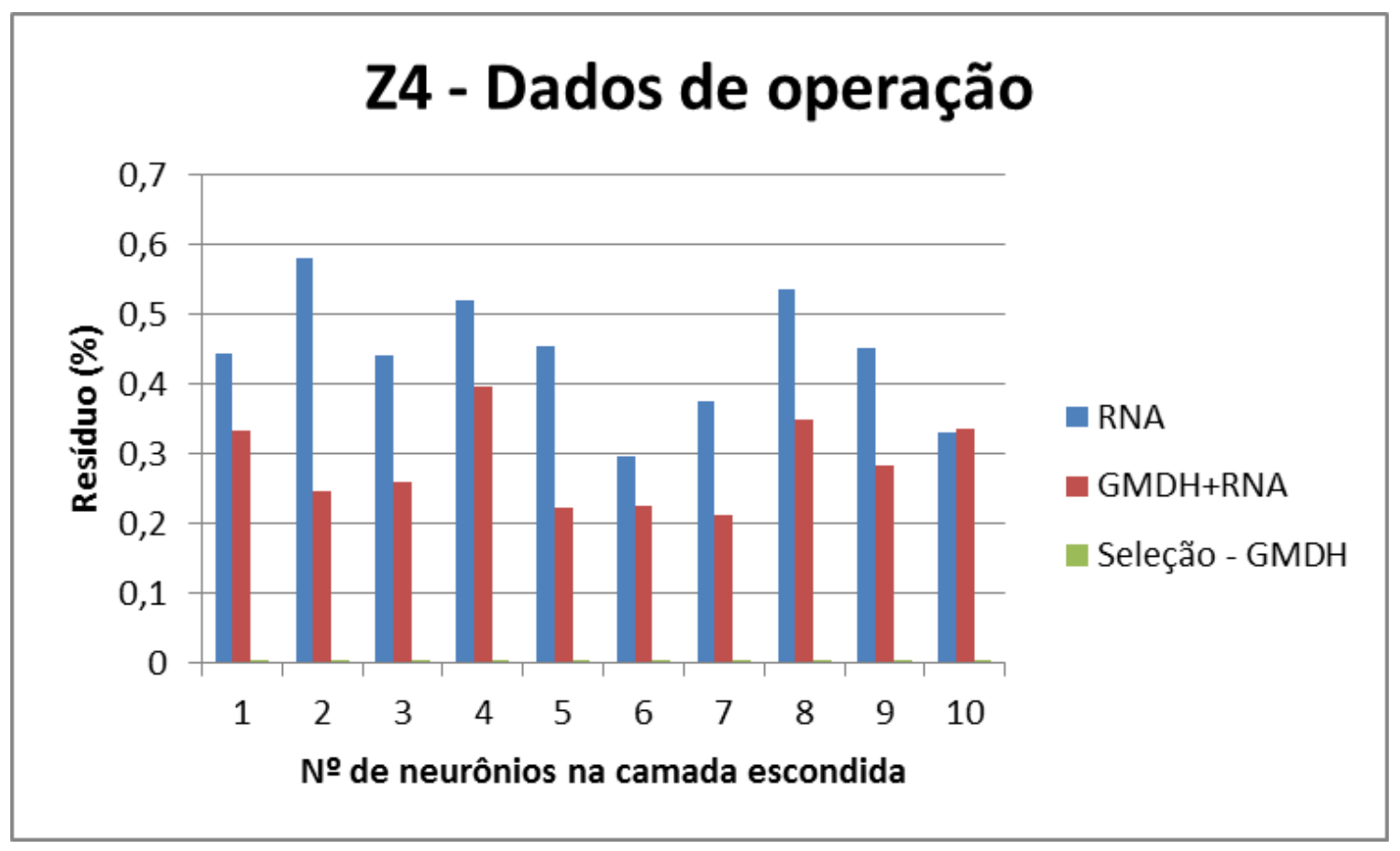

Figura 108. Monitoração de Z4 - Comparação entre as metodologias

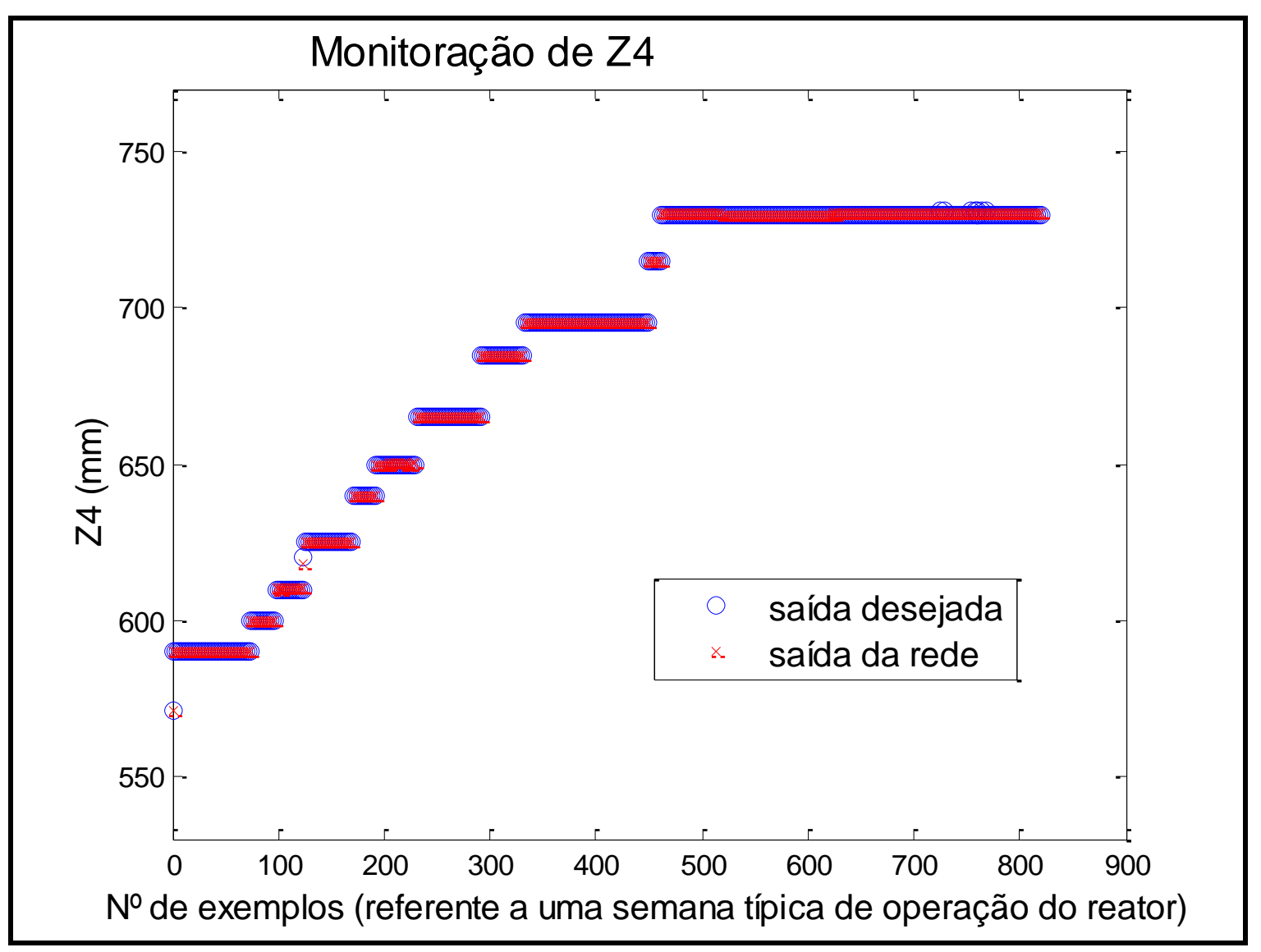

Figura 109. Saída desejada comparada à saída da rede com 10 neurônios na camada escondida 
- Monitoração de C1

Ao realizar o pré-processamento através do estudo das variáveis desconsideradas pelo GMDH, verificou-se que para a variável C1 (modelo 5), as variáveis que tiveram uma relevância maior para o GMDH foram: R8M3 e T1. Essas variáveis foram utilizadas no treinamento das RNA, onde a rede com 10 neurônios na camada escondida apresentou o menor resíduo, cujo valor foi 2,0564 (Figura 110). A Figura 111 mostra a saída da rede em função da saída desejada com 10 neurônios na camada escondida.

Como pode ser observado na Figura a seguir, o uso de GMDH + RNA apresentou os menores valores residuais.

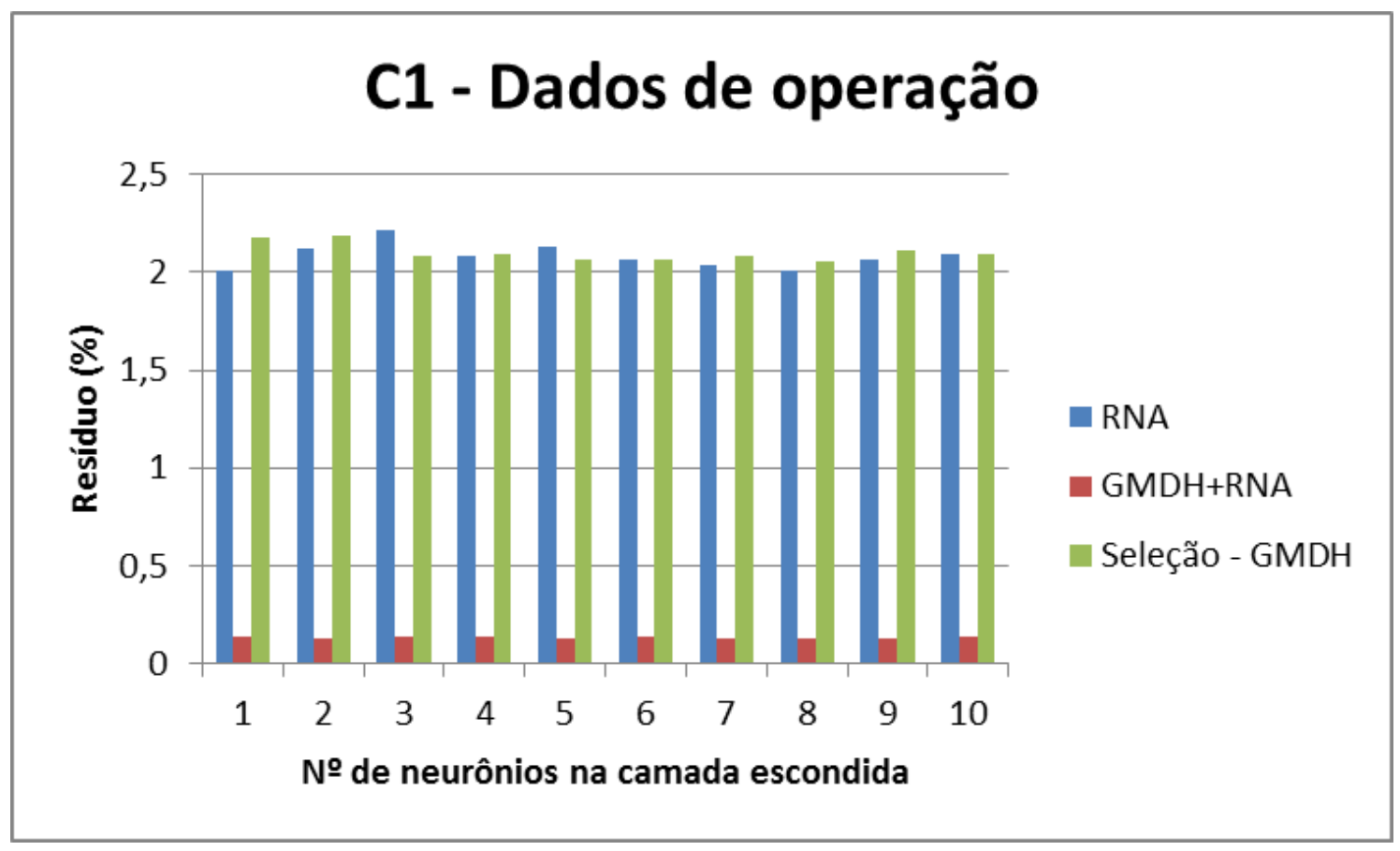

Figura 110. Monitoração de C1 - Comparação entre as metodologias 


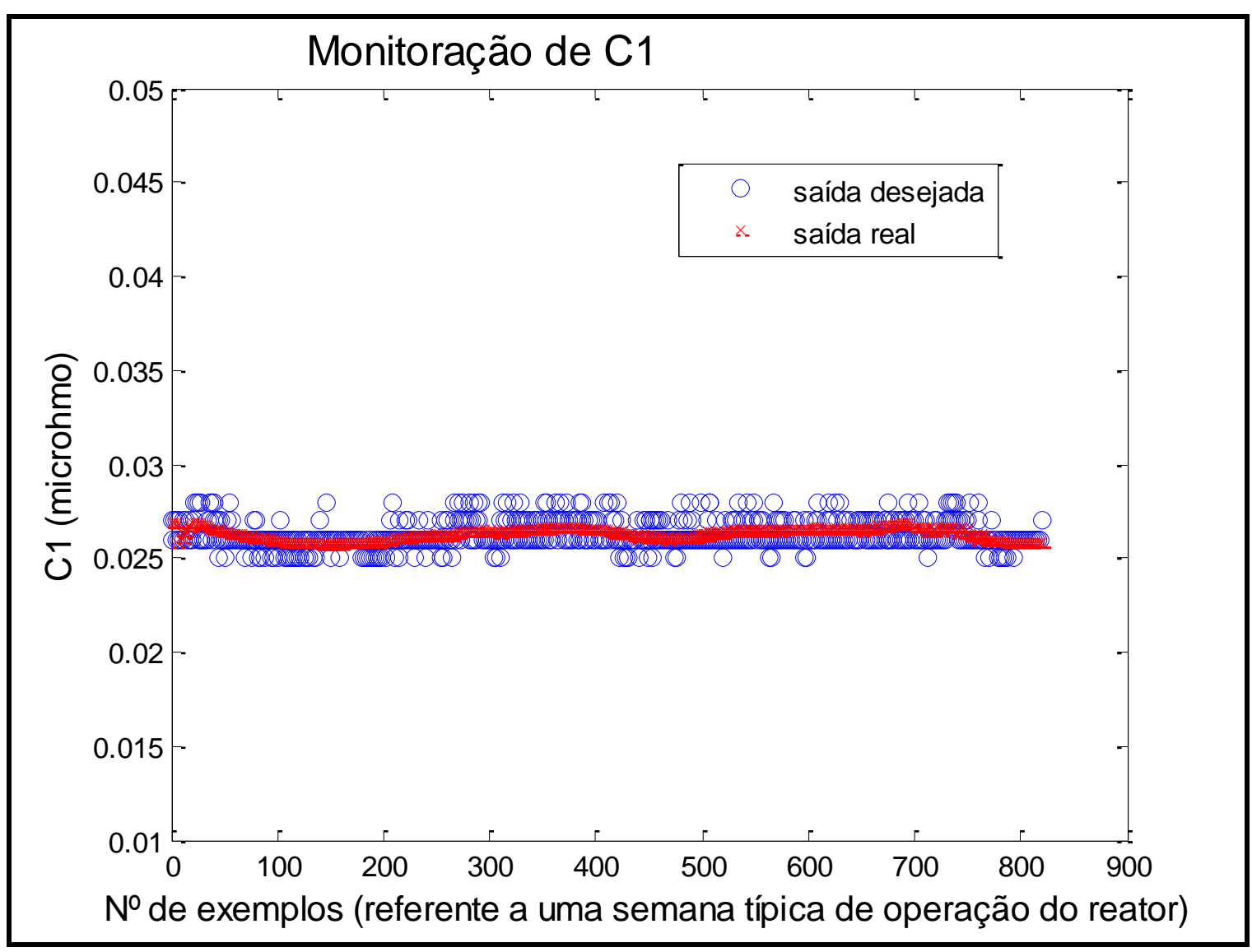

Figura 111. Saída desejada comparada à saída da rede com 10 neurônios na camada escondida

A Figura acima apresenta os resultados obtidos na monitoração de C1 usando Seleção - GMDH, porém o menor resíduo obtido foi através de GMDH + RNA.

- Monitoração de C2

Ao realizar o pré-processamento através do estudo das variáveis desconsideradas pelo GMDH, verificou-se que para a variável C2 (modelo 5), as variáveis que tiveram uma relevância maior para o GMDH foram: R8M3 e T1. Essas variáveis foram utilizadas no treinamento das RNA, onde a rede com 8 neurônios na camada escondida apresentou o menor resíduo, cujo valor foi 0,1030 (Figura 112). A Figura 113 mostra a saída da rede em função da saída desejada com 8 neurônios na camada escondida.

Como pode ser observado na Figura a seguir, o uso de RNA apresentou os menores valores residuais. 


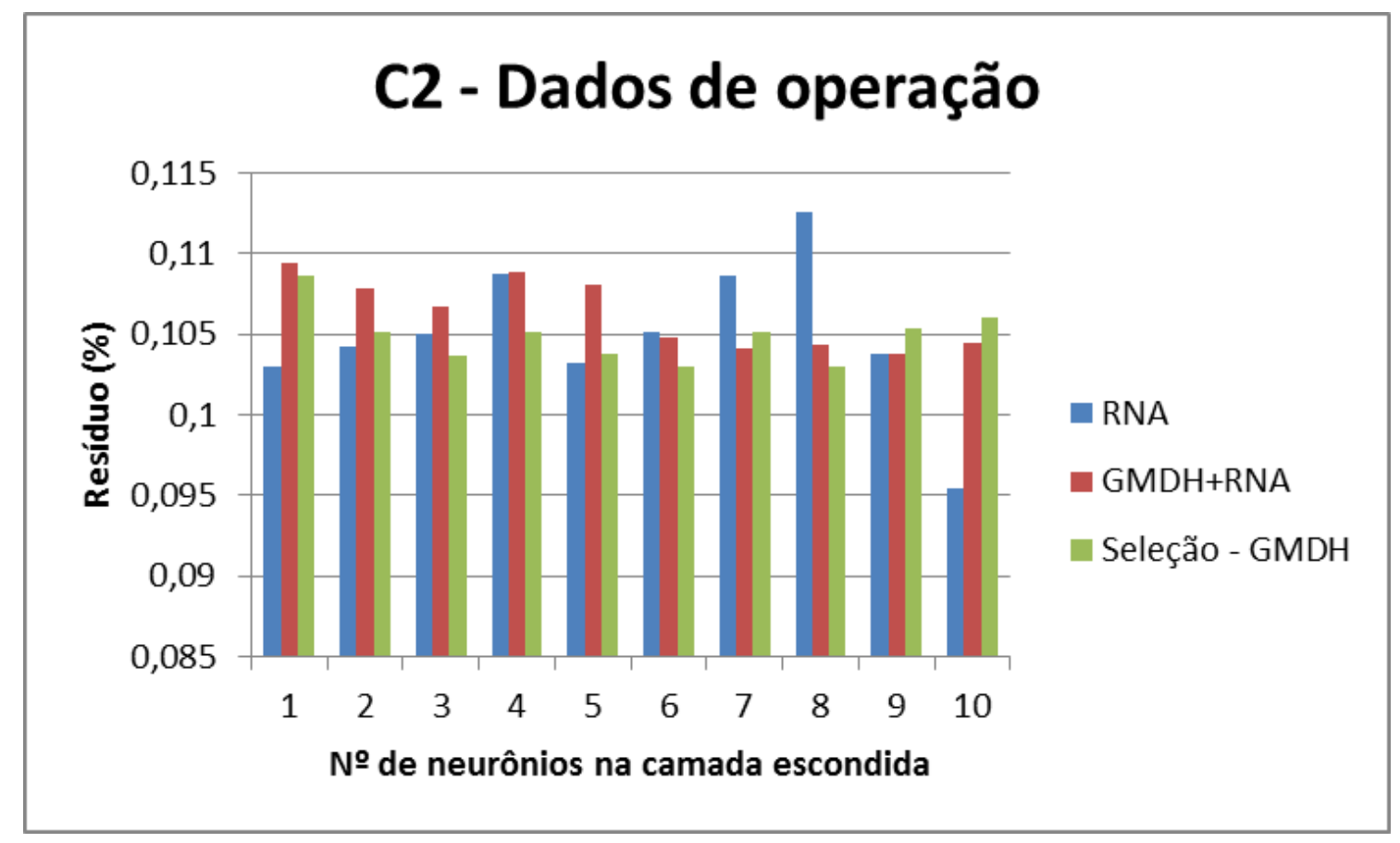

Figura 112. Monitoração de C2 - Comparação entre as metodologias

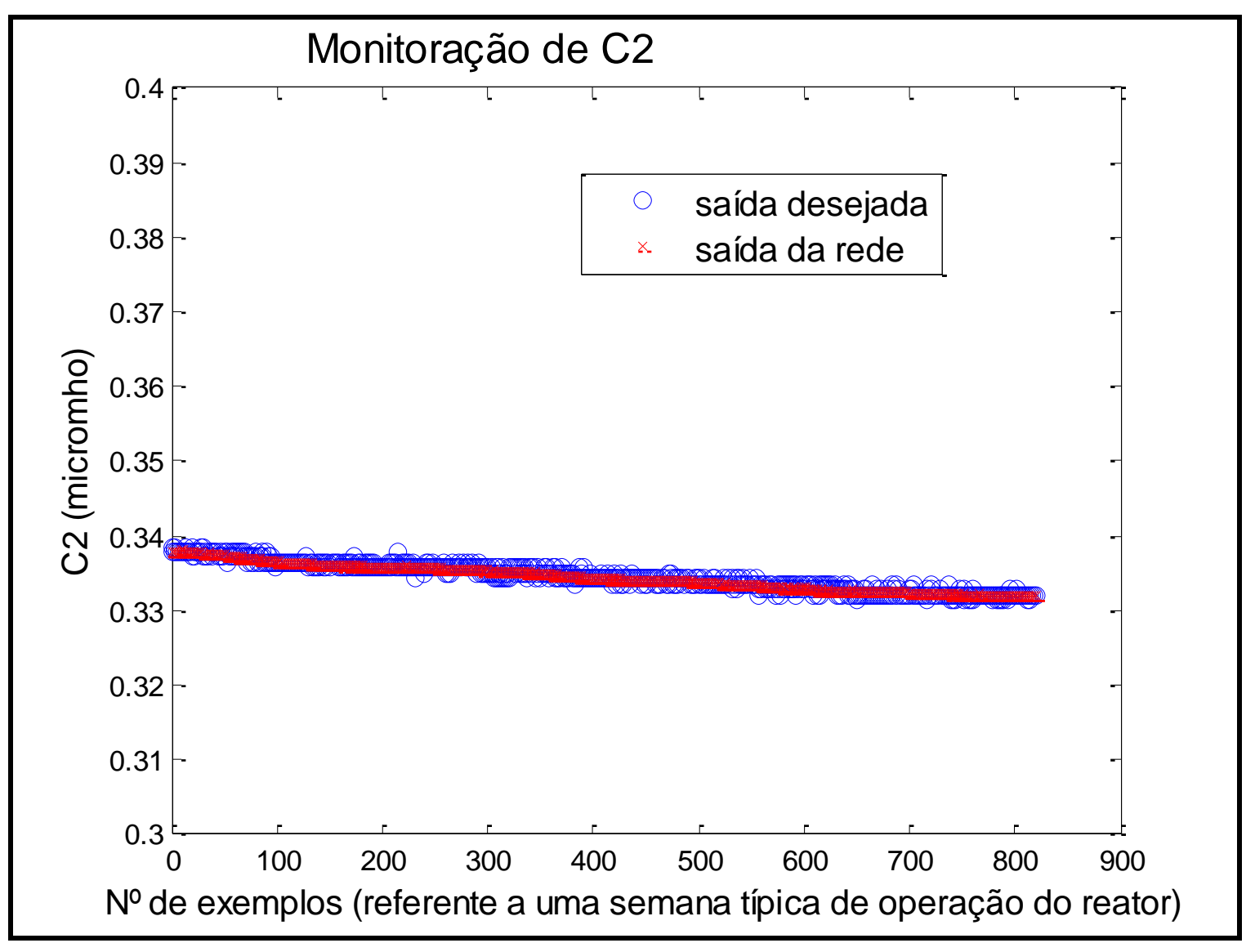

Figura 113. Saída desejada comparada à saída da rede com 8 neurônios na camada escondida 
A Figura acima apresenta os resultados obtidos na monitoração de C2 usando Seleção - GMDH, porém o menor resíduo obtido foi através RNA sem a etapa de préprocessamento.

\subsubsection{Análise dos resultados obtidos}

Na Tabela 7 será apresentada uma síntese dos melhores resultados obtidos na monitoração das variáveis abrangidas pelo modelo 5. Das 38 variáveis do modelo 5, apenas 8 variáveis não puderam ser monitoradas.

Tabela 7. Resultados obtidos na Monitoração - modelo 5

\begin{tabular}{|c|c|c|c|}
\hline \multirow{2}{*}{ Variável monitorada } & \multicolumn{3}{|c|}{ Resíduo (\%) } \\
\cline { 2 - 4 } & Seleção - GMDH & GMDH + RNA & RNA \\
\hline Z1 & 0,5279 & 1,3692 & $\mathbf{0 , 3 2 6 7}$ \\
\hline Z2 & $\mathbf{0 , 1 0 5 3}$ & 0,2362 & 0,2803 \\
\hline Z3 & $\mathbf{0 , 0 0 1 9}$ & 0,1916 & 0,3142 \\
\hline C1 & $\mathbf{0 , 0 0 3 6}$ & 0,2122 & 0,2955 \\
\hline C2 & 2,0564 & $\mathbf{0 , 1 3 0 9}$ & 2,0083 \\
\hline N1 & 0,1030 & 0,1038 & $\mathbf{0 , 0 9 5 5}$ \\
\hline N2 & --------- & -------- & -------- \\
\hline N3 & $\mathbf{0 , 1 4 1 3}$ & 0,2439 & 0,3044 \\
\hline N4 & $\mathbf{0 , 1 6 4 2}$ & 0,2347 & 0,2726 \\
\hline N5 & $\mathbf{0 , 1 5 1 1}$ & 0,2176 & 0,3041 \\
\hline N6 & --------- & -------- & -------- \\
\hline N7 & $\mathbf{0 , 1 3 4 2}$ & 0,2457 & 0,3046 \\
\hline N8 & $\mathbf{0 , 0 4 6 8}$ & 0,2176 & 0,3041 \\
\hline R1M3 & $\mathbf{0 , 4 2 9 3}$ & 0,5195 & 0,6101 \\
\hline R2M3 & $\mathbf{2 , 9 3 7 8}$ & 3,1934 & 3,2171 \\
\hline R3M3 & $\mathbf{2 , 6 2 6 8}$ & 2,7846 & 2,9562 \\
\hline R4M3 & $\mathbf{2 , 8 8 3 4}$ & 3,0375 & 4,0342 \\
\hline R5M3 & --------- & -------- & -------- \\
\hline R6M3 & --------- & -------- & --------- \\
\hline & -------- & ------- & -------- \\
\hline
\end{tabular}




\begin{tabular}{|c|c|c|c|}
\hline \multirow{2}{*}{ Variável monitorada } & \multicolumn{3}{|c|}{ Resíduo (\%) } \\
\cline { 2 - 4 } & Seleção - GMDH & GMDH + RNA & RNA \\
\hline R7M3 & $\mathbf{2 , 8 0 6 5}$ & 2,9555 & 2,8201 \\
\hline R8M3 & 1,9831 & 4,0144 & $\mathbf{1 , 7 7 8 4}$ \\
\hline R9M3 & $\mathbf{1 , 6 8 3 3}$ & 1,6640 & 1,7832 \\
\hline R10M3 & $\mathbf{3 , 1 5 9 9}$ & 3,1947 & 3,2419 \\
\hline R11M3 & $\mathbf{2 , 3 3 9 0}$ & 2,6222 & 2,3411 \\
\hline R12M3 & $\mathbf{5 , 0 5 5 1}$ & 5,0736 & 5,0919 \\
\hline R13M3 & --------- & -------- & -------- \\
\hline R14M3 & $\mathbf{6 , 0 9 3 6}$ & 6,1203 & 6,1500 \\
\hline T1 & $\mathbf{0 , 1 1 3 7}$ & 0,4630 & 0,5015 \\
\hline T2 & $\mathbf{0 , 1 0 4 9}$ & 0,4250 & 0,5172 \\
\hline T3 & $\mathbf{0 , 1 1 8 0}$ & 0,4478 & 0,5741 \\
\hline T4 & $\mathbf{0 , 0 0 2 3}$ & 0,3708 & 0,5271 \\
\hline T6 & $\mathbf{0 , 1 0 4 1}$ & 0,4390 & 0,5243 \\
\hline T7 & $\mathbf{0 , 1 4 3 6}$ & 0,4542 & 0,5166 \\
\hline T8 & $\mathbf{0 , 2 0 0 4}$ & 0,9999 & 1,1297 \\
\hline T9 & $\mathbf{0 , 1 2 2 9}$ & 0,5781 & 0,5810 \\
\hline F1M3 & -------- & -------- & -------- \\
\hline F2M3 & -------- & -------- & -------- \\
\hline
\end{tabular}

Através da análise da tabela acima, verifica-se que:

Com exceção das variáveis Z1, Z2, C1, C2 e R8M3, os resíduos obtidos utilizando-se Seleção - GMDH foram menores do que os obtidos através de GMDH + RNA e apenas RNA.

Os bons resultados obtidos neste modelo que abrange as variáveis mais importantes durante a operação do reator demonstram a viabilidade utilização do GMDH para identificar as entradas mais importantes para as RNA, e posteriormente realizar o treinamento dessas redes eliminando as informações desnecessárias. 


\section{DETECÇÃO DE FALHAS}

Após a realização de um estudo exaustivo dedicado à monitoração de sensores, iniciou-se a etapa de Detecção de Falhas, onde foram simuladas falhas na base de dados das seguintes variáveis: temperatura, radiação nuclear e potência. Para realizar a simulação de falhas foram inseridas falhas na base de dados de 5\%, 10\%, $15 \%$ e $20 \%$ acima dos valores lidos por estes sensores. A Detecção consistiu em apresentar essas bases de dados criadas às RNA como um conjunto de teste para observar os resíduos obtidos. Todas essas simulações foram aplicadas ao Modelo 5, pois é o modelo composto pelas variáveis mais importantes do $\mathrm{SAD}$, e, além disso, apresentou bons resultados na etapa de Monitoração.

Nos próximos tópicos serão apresentados os resultados obtidos na Detecção de Falha nos sensores responsáveis pela leitura das variáveis: T3, R1M3 e N2, descritas anteriormente.

\subsection{Falha em T3}

Para realizar a Detecção de Falhas em T3 foram simuladas falhas na base de dados do sensor de temperatura localizado sob o núcleo do reator [18]. Com o propósito de observar a sensibilidade da metodologia desenvolvida, estabeleceram-se os seguintes intervalos de valores como falha: $5 \%, 10 \%, 15 \%$ e $20 \%$ acima do valor lido por T3.

Nas Figuras 114 a 117 são apresentados os resultados obtidos na Detecção de Falhas em T3. 
Falha de 5\% no valor lido por T3

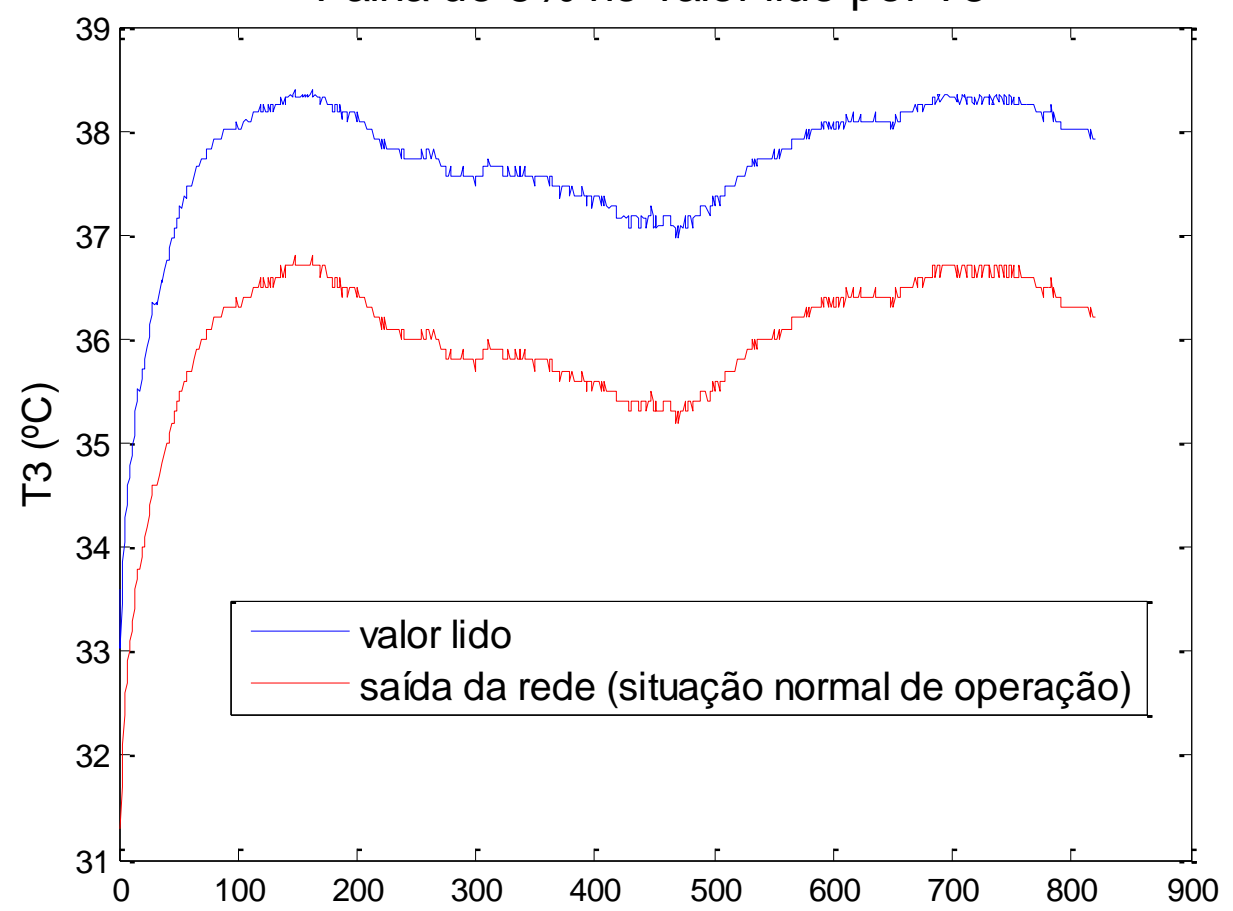

№ de exemplos (referente a uma semana típica de operação do reator)

Figura 114. Detecção de Falha em T3 - 5\% no valor lido

Falha de $10 \%$ no valor lido por T3

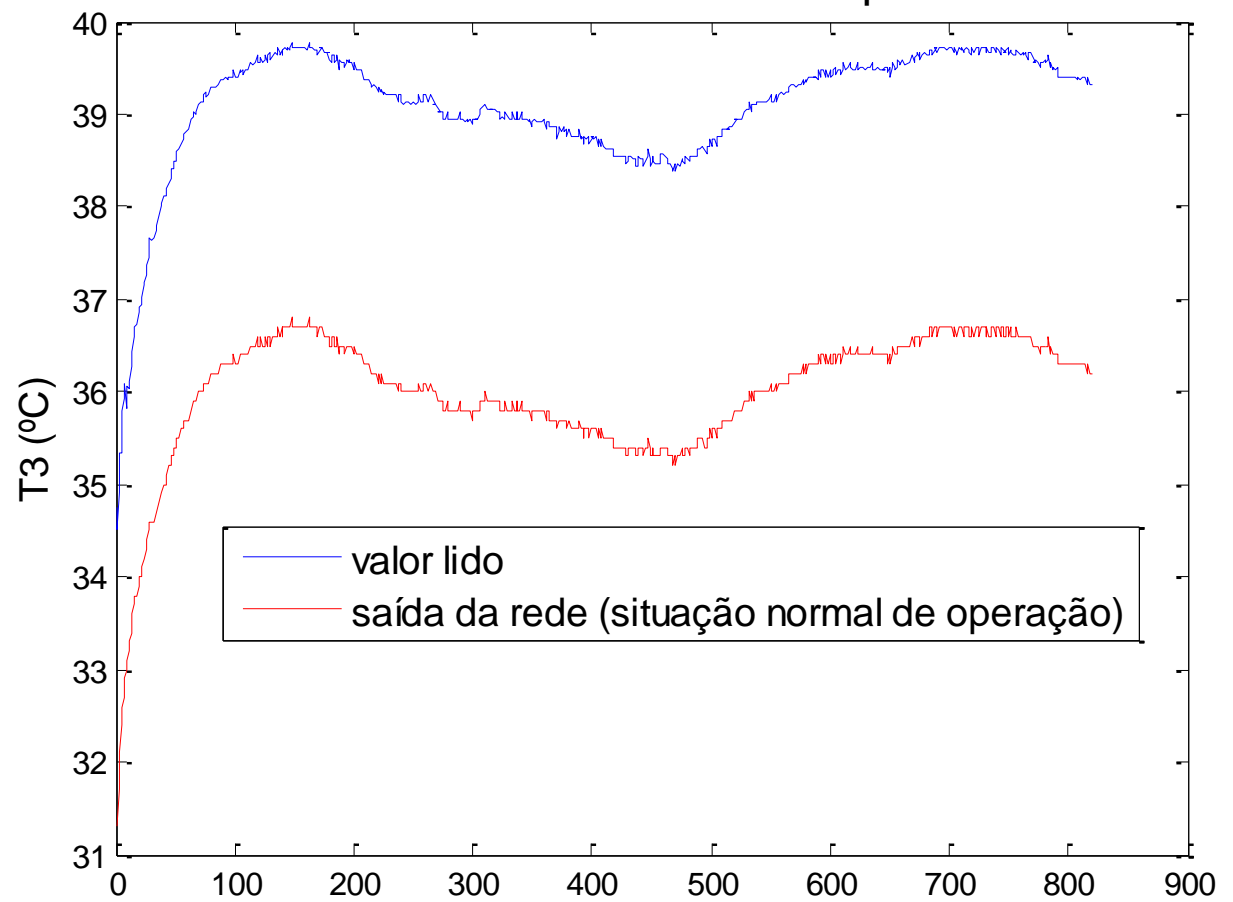

№ de exemplos (referente a uma semana típica de operação do reator)

Figura 115. Detecção de Falha em T3 - 10\% no valor lido 
Falha de $15 \%$ no valor lido por T3

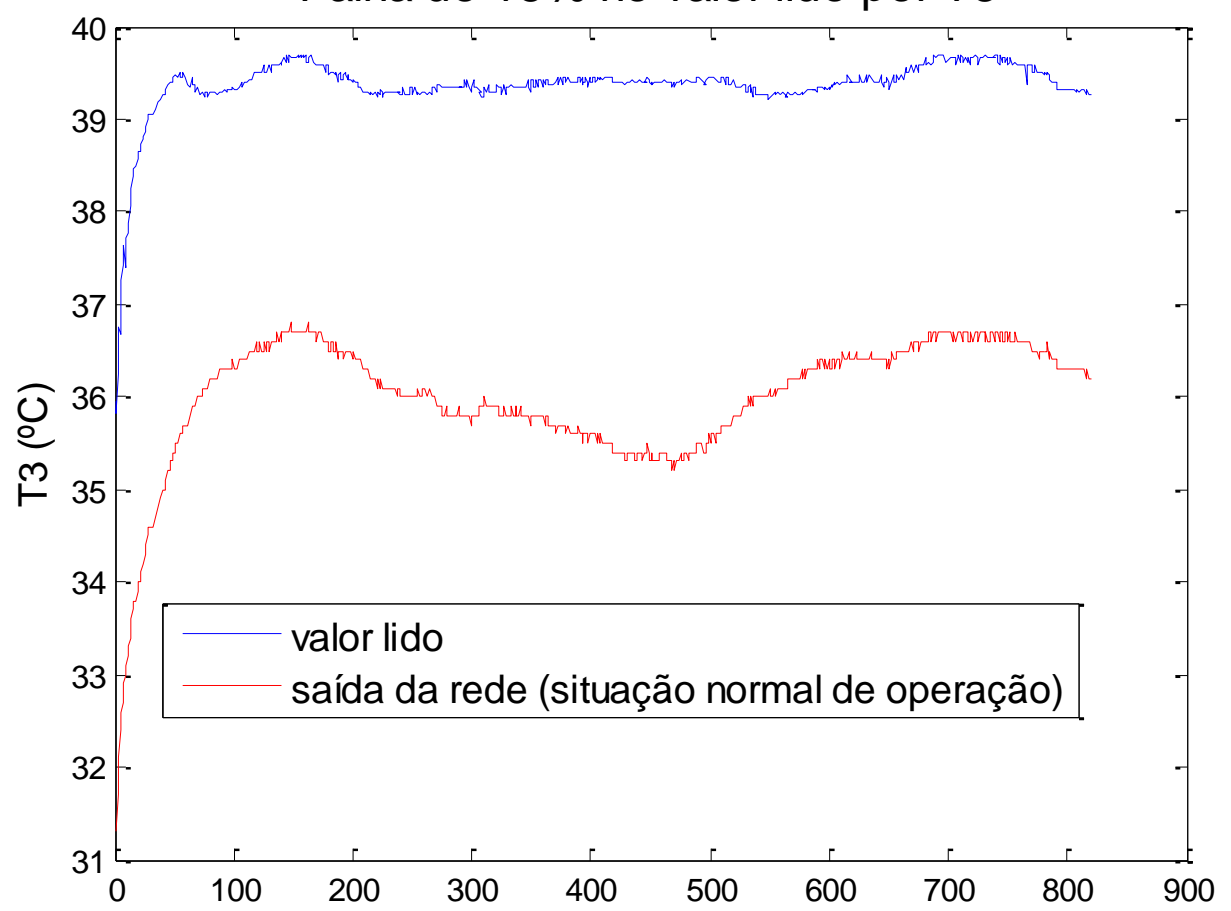

№ de exemplos (referente a uma semana típica de operação do reator)

Figura 116. Detecção de Falha em T3 - 15\% no valor lido

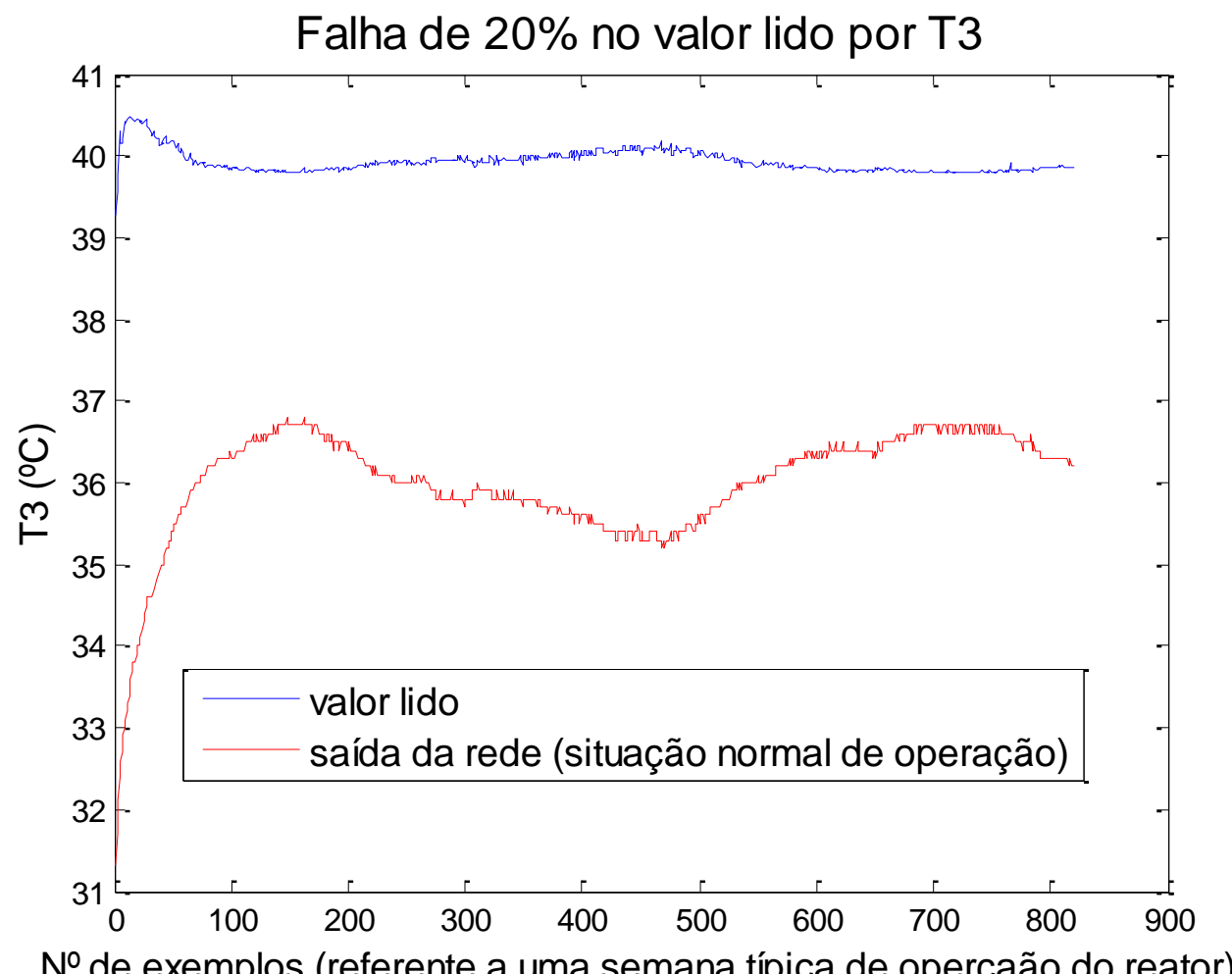

Figura 117. Detecção de Falha em T3 - 20\% no valor lido 
Na Tabela 8 são apresentados os resíduos obtidos na Detecção de Falhas em T3.

Tabela 8. Resíduos obtidos - Detecção de Falha em T3

\begin{tabular}{|l|l|}
\hline Tipo de falha & Resíduo (\%) \\
\hline $5 \%$ do valor lido & 4,76 \\
\hline $10 \%$ do valor lido & 6,30 \\
\hline $15 \%$ do valor lido & 9,34 \\
\hline $20 \%$ do valor lido & 10,88 \\
\hline
\end{tabular}

Através da análise da tabela acima, é possível identificar que existe alguma anomalia no sensor de temperatura T3, uma vez que o resíduo obtido para a Monitoração desta variável foi de $0,12 \%$ e os resíduos obtidos na Detecção ultrapassaram este valor (vide Tabela 8).

\subsection{Falha em R1M3}

Para realizar a Detecção de Falhas em R1M3 foram simuladas falhas na base de dados do sensor de temperatura localizado sob o núcleo do reator. Com o propósito de observar a sensibilidade da metodologia desenvolvida, estabeleceram-se os seguintes intervalos de valores como falha: 5\%, 10\%, 15\% e 20\% acima do valor lido por R1M3.

Nas Figuras 118 a 121 são apresentados os resultados obtidos na Detecção de Falhas em R1M3. 
Falha de 5\% no valor lido por R1M3

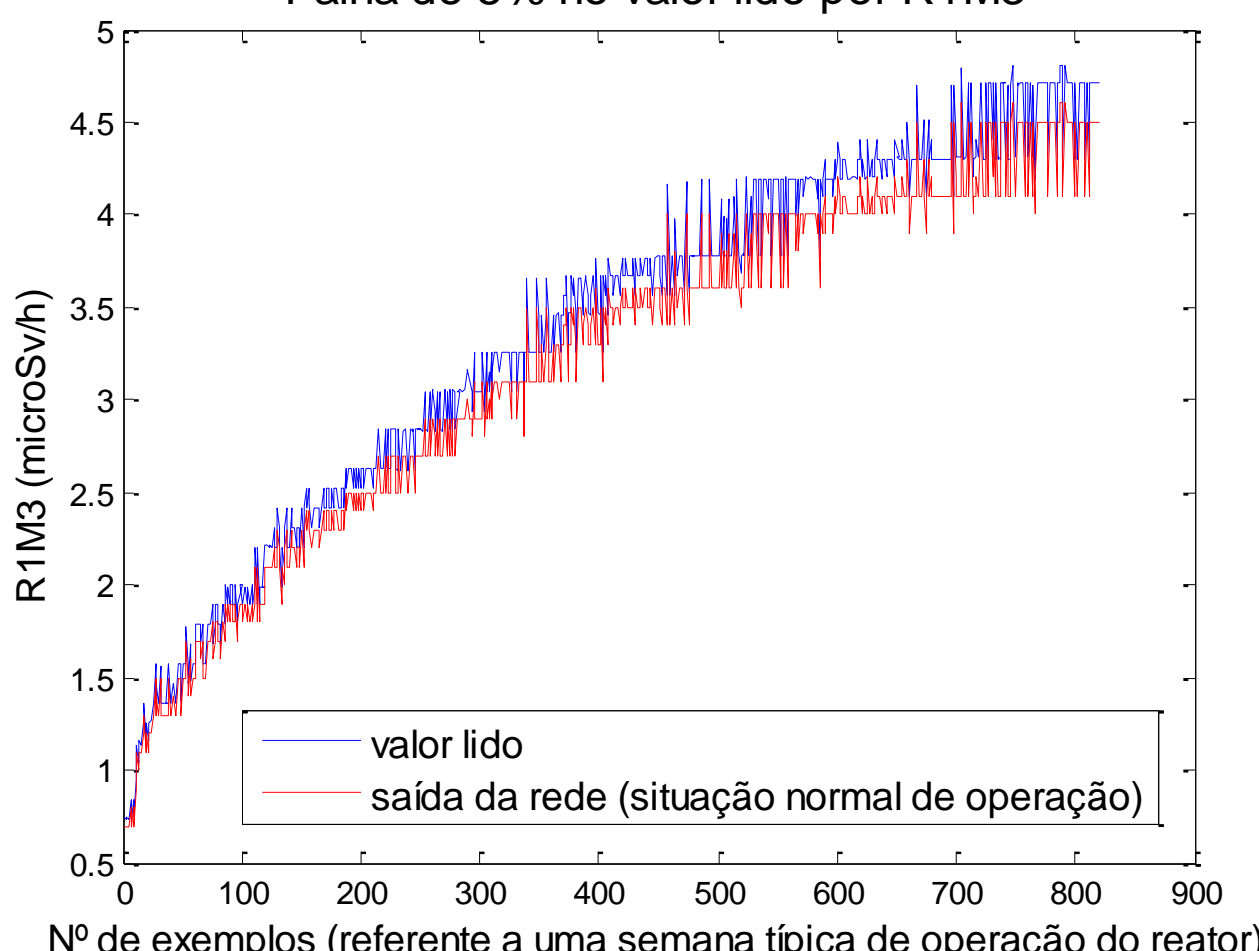

Figura 118. Detecção de Falha em R1M3 - 5\% no valor lido

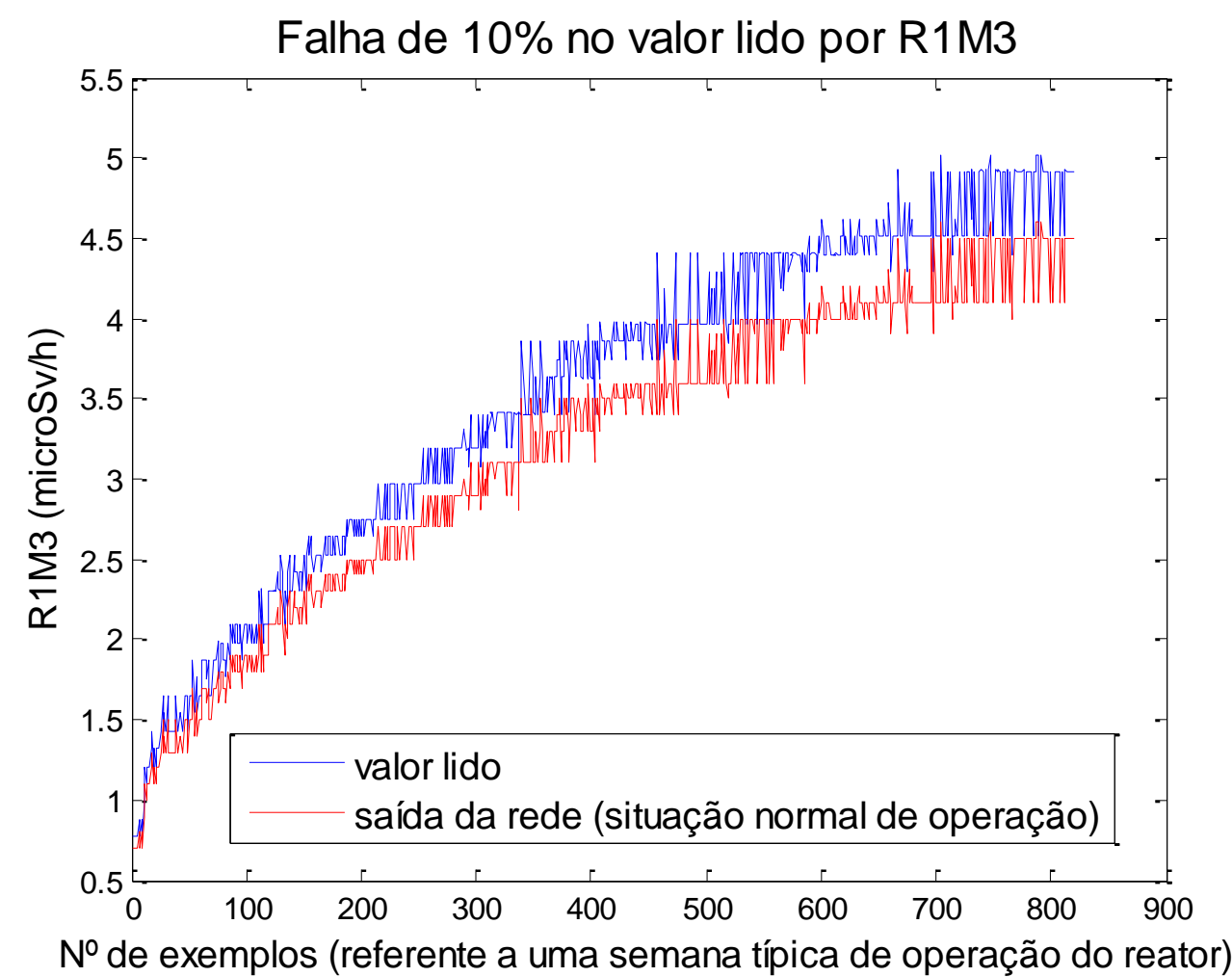

Figura 119. Detecção de Falha em R1M3 - 10\% no valor lido 
Falha de $15 \%$ no valor lido por R1M3

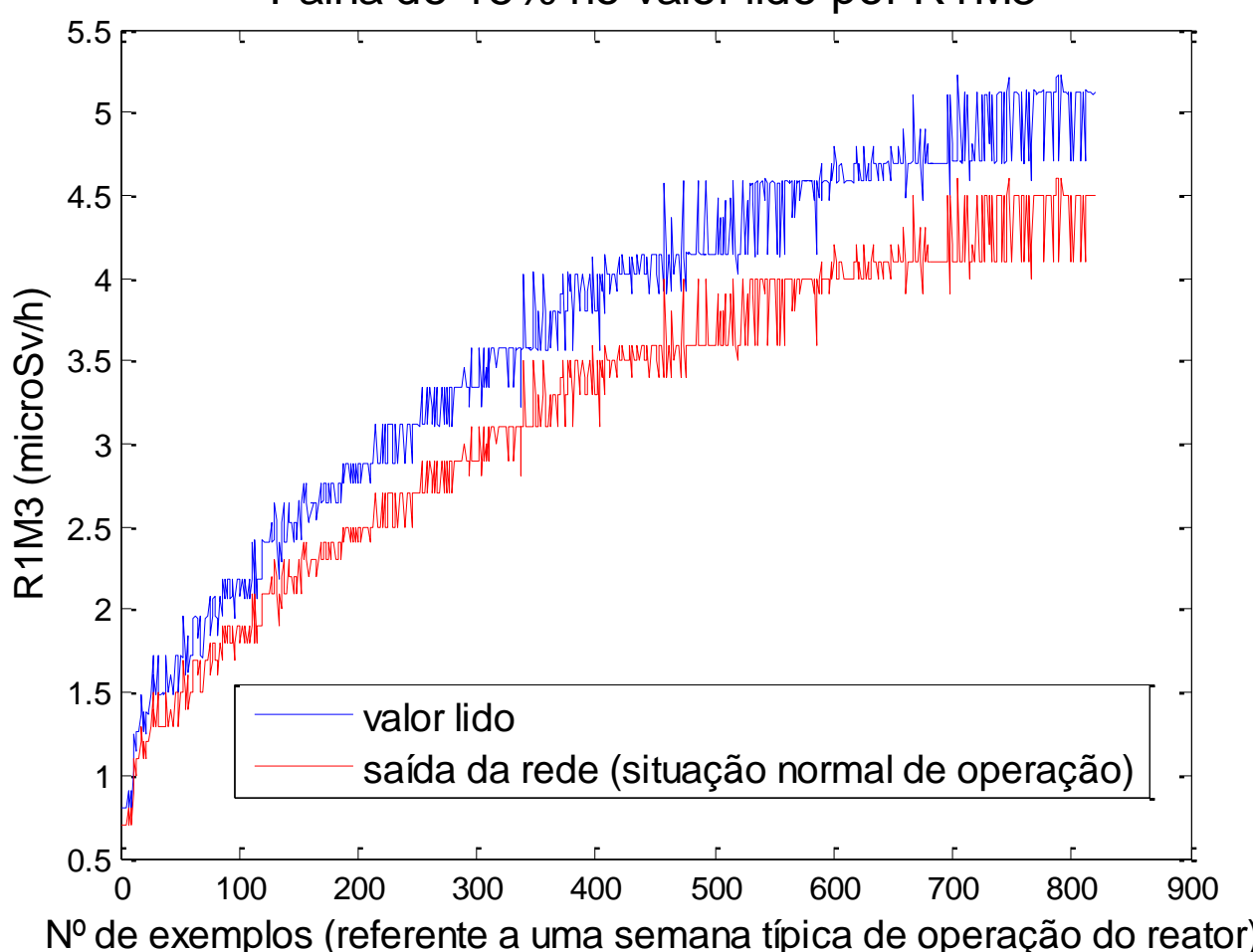

Figura 120. Detecção de Falha em R1M3 - 15\% no valor lido

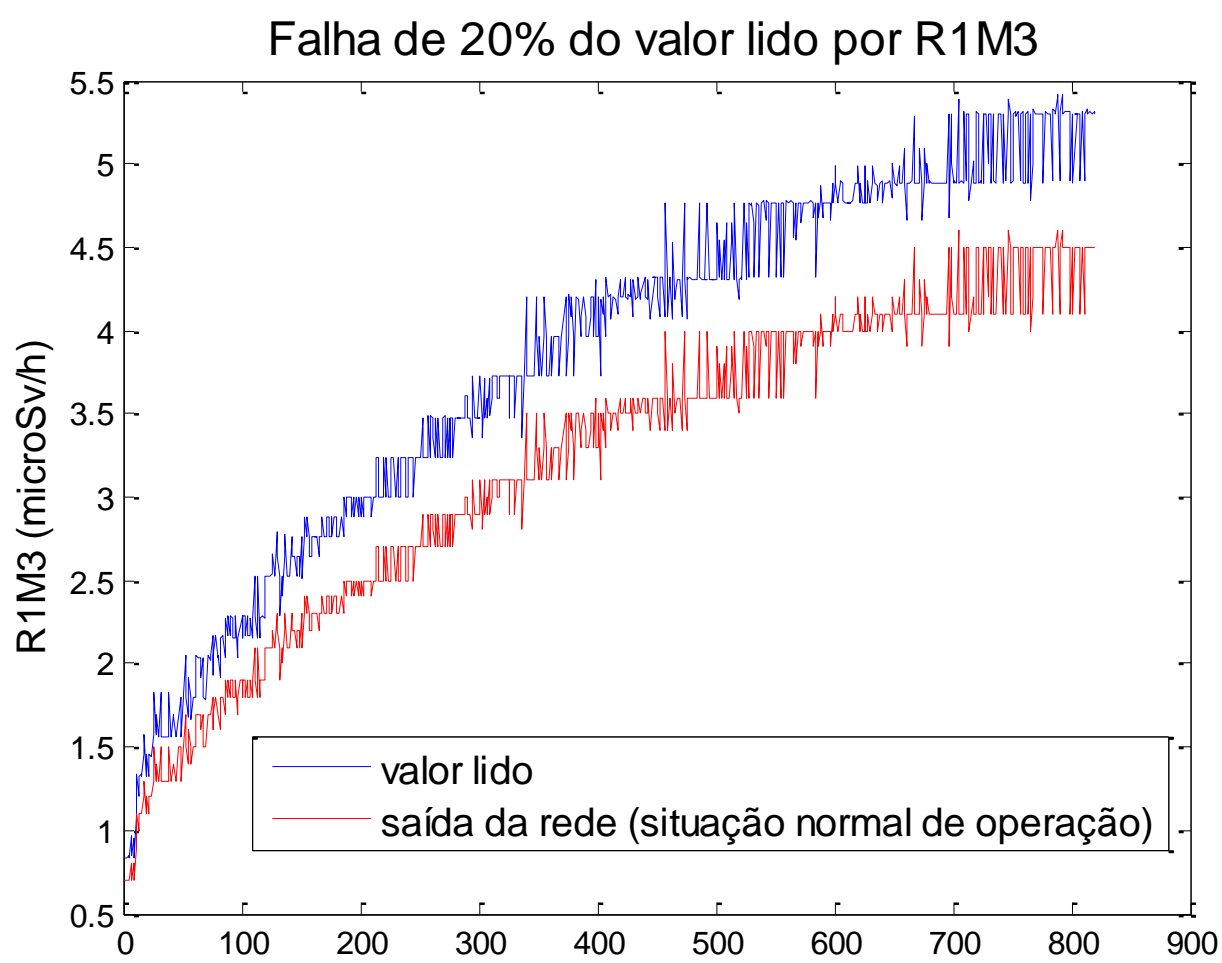

№ de exemplos (referente a uma semana típica de operação de reator)

Figura 121. Detecção de Falha em R1M3 - 20\% no valor lido 
Na Tabela 9 são apresentados os resíduos obtidos na Detecção de Falhas em R1M3.

Tabela 9. Resíduos obtidos - Detecção de Falha em R1M3

\begin{tabular}{|l|l|}
\hline Tipo de falha & Resíduo (\%) \\
\hline $5 \%$ do valor lido & 4,90 \\
\hline $10 \%$ do valor lido & 9,89 \\
\hline $15 \%$ do valor lido & 14,92 \\
\hline $20 \%$ do valor lido & 19,31 \\
\hline
\end{tabular}

Através da análise da tabela acima, é possível identificar que existe alguma anomalia no sensor responsável pela medição de radiação (R1M3), uma vez que o resíduo obtido para a Monitoração desta variável foi de 2,94\% e os resíduos obtidos na Detecção ultrapassaram este valor (vide Tabela 9).

\subsection{Falha em $\mathbf{N} 2$}

Para realizar a Detecção de Falhas em N2 foram simuladas falhas na base de dados do sensor de temperatura localizado sob o núcleo do reator. Com o propósito de observar a sensibilidade da metodologia desenvolvida, estabeleceram-se os seguintes intervalos de valores como falha: $5 \%, 10 \%, 15 \%$ e $20 \%$ acima do valor lido por N2.

Nas Figuras 122 a 125 são apresentados os resultados obtidos na Detecção de Falhas em N2. 
Falha de 5\% no valor lido por N2

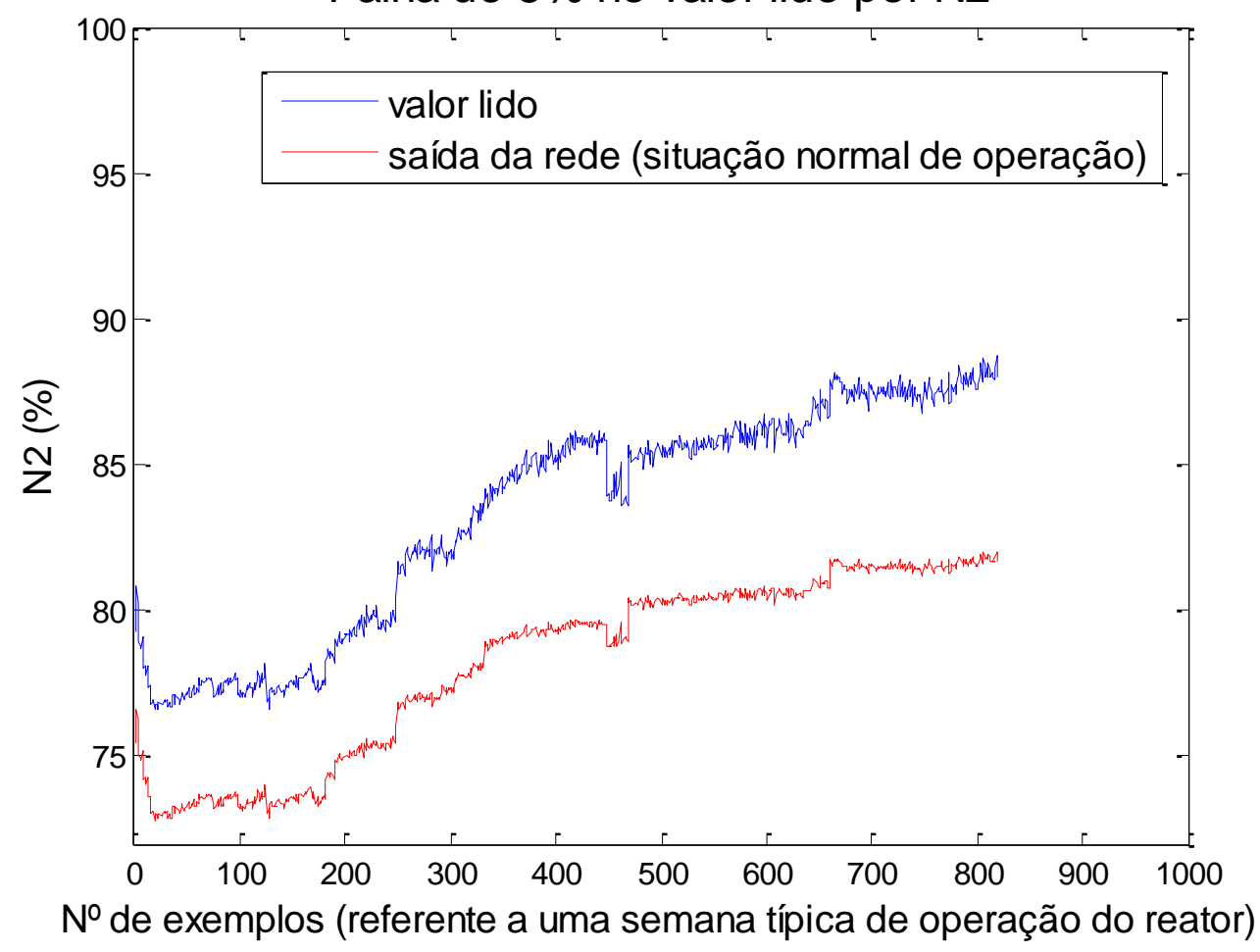

Figura 122. Detecção de Falha em R1M3 - 5\% no valor lido

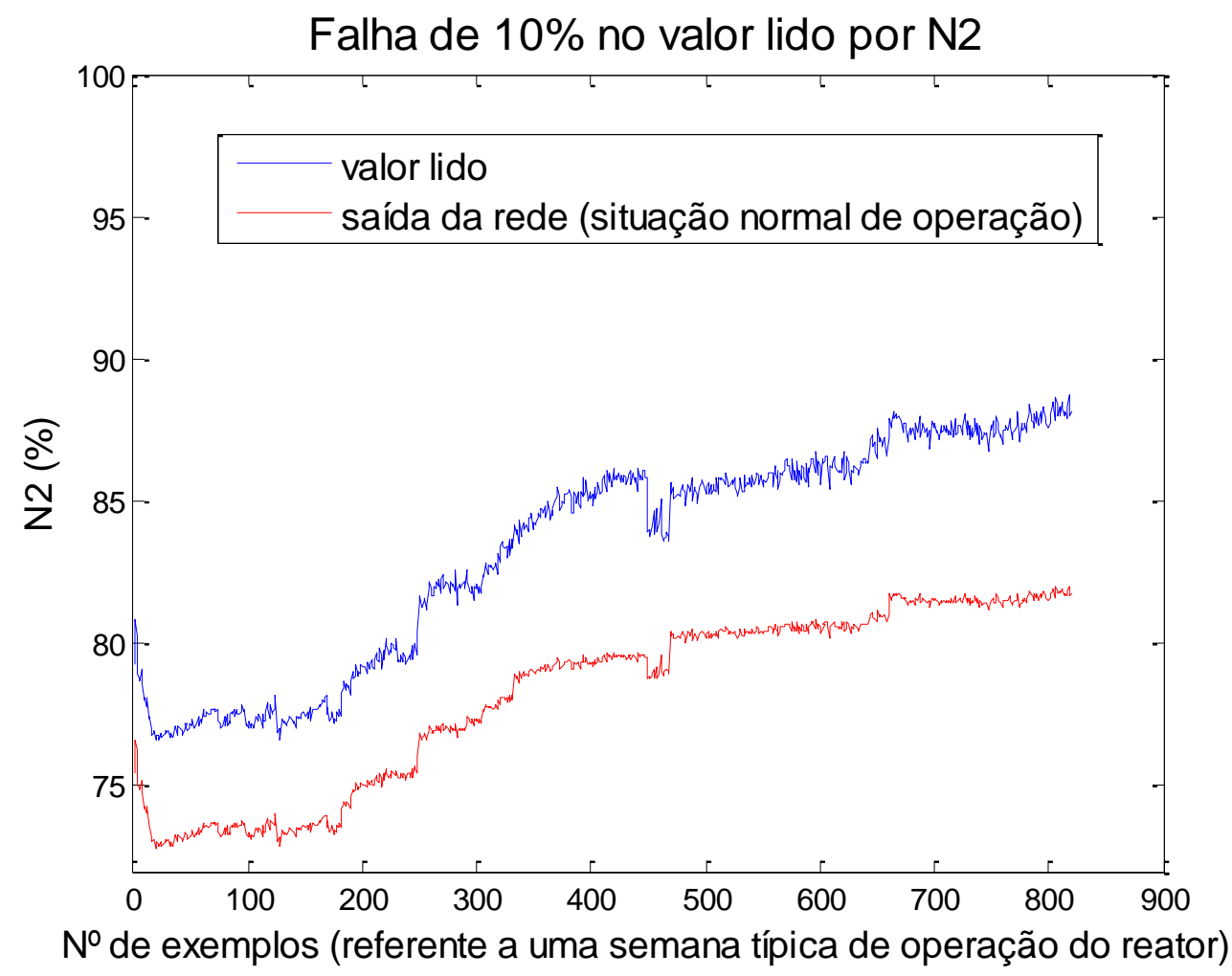

Figura 123. Detecção de Falha em R1M3 - 10\% no valor lido 


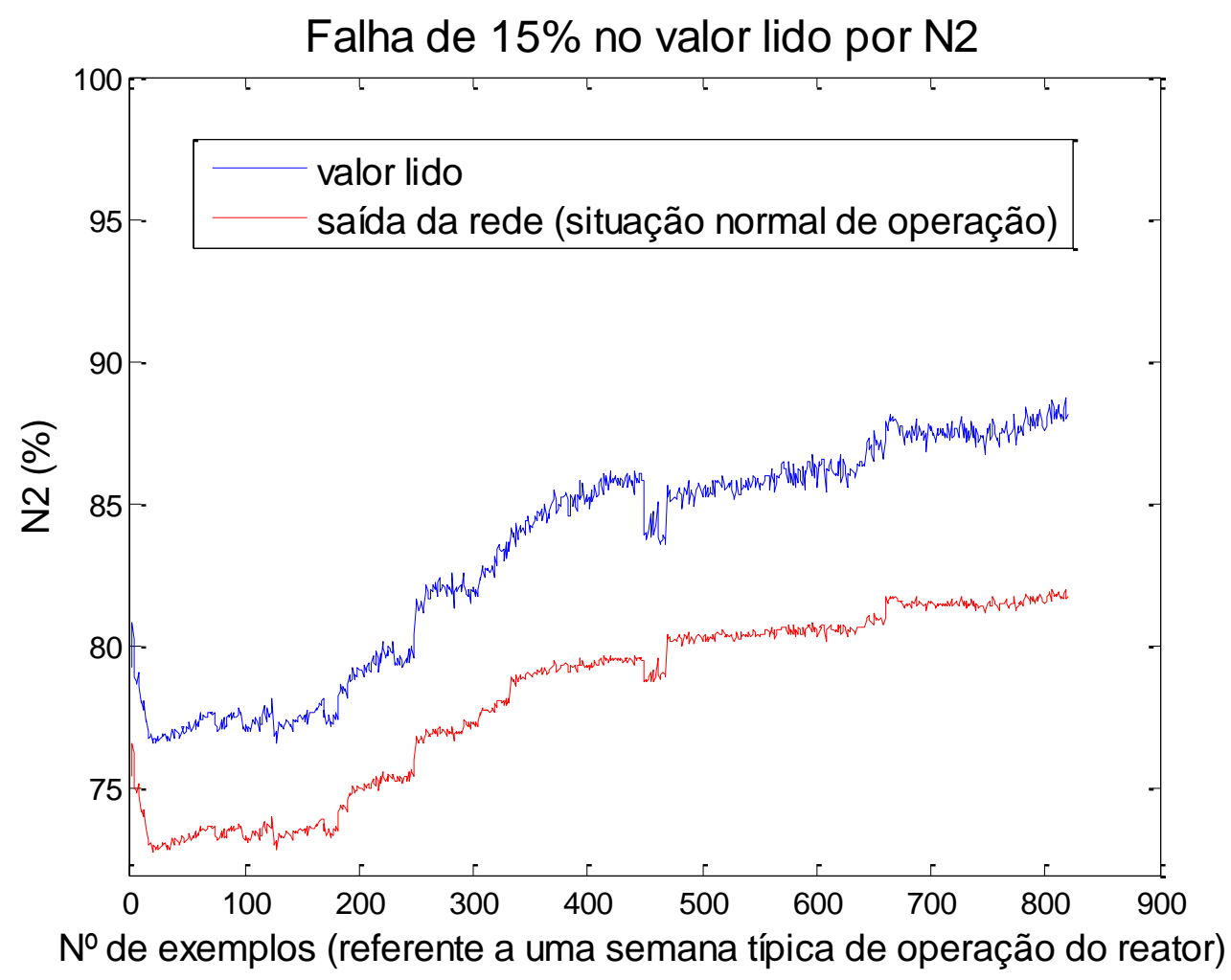

Figura 124. Detecção de Falha em R1M3 - 15\% no valor lido

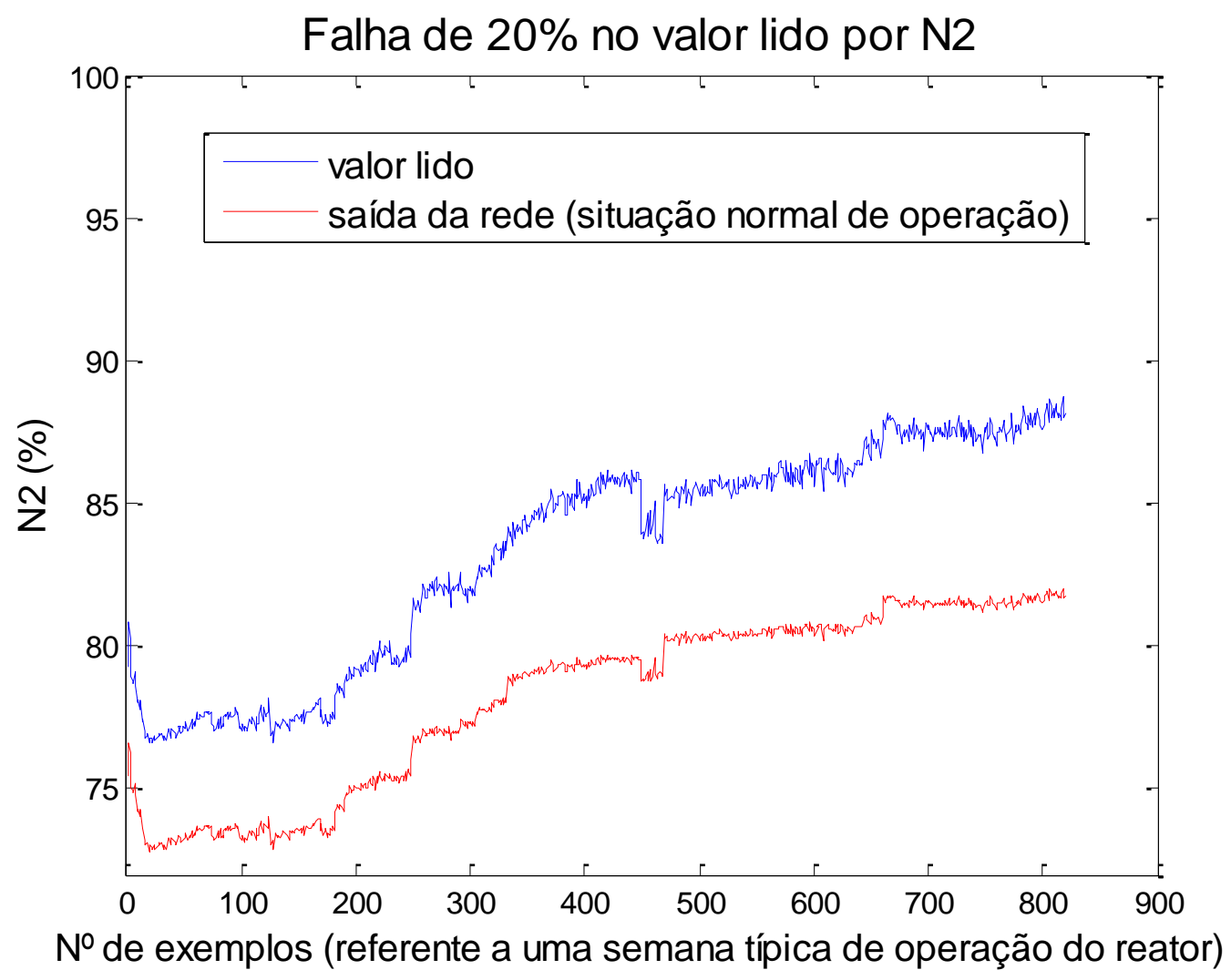

Figura 125. Detecção de Falha em R1M3 - 20\% no valor lido 
Na Tabela 10 são apresentados os resíduos obtidos na Detecção de Falhas em R1M3.

Tabela 10. Resíduos obtidos - Detecção de Falha em N2

\begin{tabular}{|l|l|}
\hline Tipo de falha & Resíduo (\%) \\
\hline $5 \%$ do valor lido & 6,58 \\
\hline $10 \%$ do valor lido & 9,96 \\
\hline $15 \%$ do valor lido & 12,83 \\
\hline $20 \%$ do valor lido & 15,23 \\
\hline
\end{tabular}

Através da análise da tabela acima, é possível identificar que existe alguma anomalia no sensor responsável pela medição de potência nuclear (N2), uma vez que o resíduo obtido para a Monitoração desta variável foi de $0,14 \%$ e os resíduos obtidos na Detecção ultrapassaram este valor (vide Tabela 10). 


\section{CONCLUSÕES}

O objetivo deste trabalho é mostrar a viabilidade de utilização dos métodos GMDH e Redes Neurais no desenvolvimento de uma metodologia inédita de Monitoração e Detecção de Falhas em sensores de centrais nucleares. Para a implementação da metodologia proposta, este trabalho foi dividido em duas etapas: pré-processamento das informações de entrada através do algoritmo GMDH e o processamento dessas informações através do treinamento de RNA para realizar a Monitoração dos sensores.

A etapa de pré-processamento do Sistema de Monitoração e Detecção de Falhas em sensores utilizando GMDH e RNA foi feita de duas maneiras diferentes. Na primeira etapa utilizou-se a matriz_z como uma nova estimativa das variáveis de entrada no treinamento das RNA. Para tanto foram propostos diferentes conjuntos de variáveis de entrada (cinco modelos), sendo 1 Modelo teórico e 4 Modelos utilizando dados de operação do reator. Esses modelos foram utilizados na primeira fase de desenvolvimento da presente metodologia (pré-processamento) através do algoritmo GMDH para a obtenção de uma melhor estimativa das variáveis de entrada, e posteriormente, na etapa de processamento de informações, onde foram treinadas diversas RNA para estabelecer o melhor sistema de monitoração.

Os resultados obtidos nessa primeira fase acabaram estimulando o estudo das variáveis desconsideradas pelo GMDH. Para tanto, observou-se as variáveis que tiveram uma maior predominância na equação polinomial, ou seja, levou-se em consideração o número de vezes que essas variáveis apareceram após a aplicação do algoritmo para a obtenção da matriz_z. As variáveis que tiveram uma predominância maior foram utilizadas na etapa de processamento, ou seja, no treinamento das RNA. Tendo em vista o número de variáveis abrangidas pelos modelos, decidiu-se utilizar os modelos 3, 4 e 5 .

No que se refere à utilização de duas formas distintas para realizar o préprocessamento das informações, observa-se que os melhores resultados obtidos foram através da investigação das variáveis desconsideradas pelo GMDH (RNA - seleção), pois os valores de resíduos encontrados, para a maioria dos casos estudados, foram menores do que aqueles obtidos com as demais metodologias (GMDH + RNA e RNA). 
Ao compararmos os resultados obtidos entre os diversos modelos, verifica-se que o melhor modelo de Monitoração é o modelo 5. Este modelo é de extrema importância, pois abrange as variáveis mais relevantes durante a operação do reator IEA$\mathrm{R} 1$, apresentando valores de resíduos da ordem de $\sim 0,1 \%$ para as variáveis de temperatura, e de, no máximo, $6 \%$ para as variáveis de radiação nuclear, 0,4\% para as variáveis de potência, 0,5\% para as variáveis de posição de barras, e $2 \%$ para as variáveis de condutividade da água.

Na Detecção de Falhas foram simuladas falhas na base de dados das seguintes variáveis: T3, R1M3 e N2. Para tanto, adotou-se o critério de simular falhas representadas pelo acréscimo de 5\%,10\%, 15\% e 20\% nos valores lidos por estes sensores. Os resultados obtidos nesta etapa mostram que os resíduos na Detecção foram maiores do que os obtidos na Monitoração.

Os resultados obtidos neste trabalho contribuíram para o desenvolvimento de uma nova metodologia de Monitoração e Detecção de Falhas em sensores de centrais nucleares, que utiliza a seleção automática das variáveis de entrada independentemente do conhecimento especialista para realizar a modelagem do sistema.

\subsection{Recomendações para trabalhos futuros}

Expandir o sistema de Monitoração utilizando uma nova base de dados que contenha várias semanas de operação do reator, na mesma condição de potência;

* Elaborar um novo modelo para monitorar a vazão do primário e do secundário;

* Ampliar o estudo de Detecção de Falhas, através da simulação de falhas em outros sensores;

* Estudar a utilização de métodos estatísticos e suas possíveis aplicações na Detecção de Falhas em sensores;

* Testar a implementação desta metodologia nas usinas nucleares brasileiras, pois isso não implica em nenhuma modificação na instrumentação existente;

* Estudar Algoritmos Genéticos na seleção das variáveis de entrada para as RNA, possibilitando assim um estudo comparativo com a presente metodologia. 


\section{REFERÊNCIAS BIBLIOGRÁFICAS}

1. BLANKE, T.; HAMMEL, U.; SCHWEFEL, H. P. Evolutionary computation: Comments on the history and current state. IEEE Transactions on Evolutionary Computation, v. 1, p. 3-17, 1997.

2. BRAGA, A. P.; CARVALHO, A. P. L. F.; LUDERMIR, B. Redes Neurais Artificiais - Teoria e Aplicações. 2a ${ }^{\mathrm{a}}$. ed. Rio de Janeiro: LTC, 2007.

3. BROSSE, S. et al. The use of neural networks to asses fish abundance and spatial occupancy in the littoral zone of a mesotrophic lake. Ecological Modelling, v. 120, n. 2-3, p.299-311, 1999.

4. BUENO, E. I. Utilização de Redes Neurais Artificiais na Monitoração e Deteç̧ão de Falhas em sensores do reator IEA-R1. Dissertação (Mestrado), Universidade de São Paulo - IPEN, 2006.

5. CHUNG, H. Y. et al. Incipient multiple Fault Diagnosis in real time with application to large-scale sytems. IEEE Transaction on Nuclear Science, v. 41, p. 1691-1703, 1994.

6. FARLOW, S. J. Self-organizing methods in modeling: GMDH-type algorithms. New Your: M. Dekker, 1984.

7. FAUSSET, L. Fundamentals of neural networks architectures, algorithms and applications. New Jersey, 1994.

8. FERREIRA, P. B. Incipient Fault Detection and Isolation of sensors and field devices. Tese (Doutorado) - University of Tennessee, 1999.

9. GARCIA, D. A. A. Metodologia de Diagnóstico automático de falhas de curtocircuito em alimentadores primários de sistemas de distribuição reticulados tipo spot. Tese (Doutorado), Universidade de São Paulo - Escola Politécnica, 2006.

10. GOODE, P. V. Using a Neural/Fuzzy System to extract heuristic knowledge of incipient faults in induction motor: Part I - Methodology. IEEE Transactions on Industrial electronics, v. 42, n. 2, p. 131-138, 1995.

11. HAGAN, M. T.; DEMUTH, H. B.; BEALE, M. Neural Network Design. PWS Publishing Company, 1996. 
12. HAYKIN, S. Neural Networks - A comprehensive foundation. Prentice Hall, 1999.

13. HEBB, D. O. The organization of behavior: a neuropsychological theory. New York: Wiley, 1949.

14. KALOGIROU, S. A. Application of artificial neural networks for energy systems. Applied Energy, v. 67, n. 1-2, p. 17-35, 2000.

15. KORBICZ, J. et al. Fault Diagnosis - Models, Artificial Intelligence, Applications. Berlin: Springer, 2004.

16. LO, C. H.; WONG, Y. K.; RAD, A. B. Intelligent System for Process Supervision and Fault Diagnosis in Dynamic Physical Systems. IEEE Transactions on Industrial Electronics, v. 53, n. 2, p. 581-592, 2006.

17. MAKI, Y.; LOPARO, K. A. A Neural Network approach to fault detection and diagnosis in industrial processes. IEEE Transactions on Control Systems Technology, v. 5, n. 2, p. 529-541, 2002.

18. Manual on the use of thermocouples in temperature measurement. ASTM STP 470B. AMERICAN SOCIETY FOR TESTING AND MATERIALS, 1983.

19. MCCULLOCH, W. S.; PITTS, W. A logical calculus of the ideas immanent in nervous activity. Bulletin of Mathematical Biophysics, v. 5, p. 115-133, 1943.

20. MORALES, R. A. G. MODELAGEM E ANÁLISE DE SISTEMAS FLEXÍVEIS DE MANUFATURA TOLERANTES À FALHAS BASEADO EM REDE BAYESIANA E REDE DE PETRI. Dissertação (Mestrado), Universidade de São Paulo - Escola Politécnica, 2009.

21. NA, M. G. et al. Sensor Monitoring using a Fuzzy Neural Network with an Automatic Structure Constructor. IEEE Transactions on Nuclear Science, v. 50, n. 2, p.241-250, 2003.

22. PATTON, R. J.; CHEN, J.; NIELSEN, S. B. Model-based methods for Fault Diagnosis: some guidelines. IEEE Transactions of the Institute of Measurement and Control, v. 17, 1995.

23. PEREIRA, I. M.; TING, D. K. S. A theoretical model for the IPEN research reactor IEA-R1. INAC 2005 - International Nuclear Atlantic Conference Proceedings (Cdroom), Santos, Agosto 2005. 
24. PEREIRA, I. M. Monitoração e diagnóstico para detecção de falhas de sensores utilizando a metologia GMDH. Tese (Doutorado), Universidade de São Paulo IPEN, 2006.

25. PUIG, V. et al. A GMDH neural network-base approach to passive robust fault detection using a constraint satisfaction backward test. Engineering Applications of Artificial Intelligence, v. 20, n. 7, p. 886-897, 2007.

26. RAYMER, M. L. et al. Dimensionality reduction using Genetic Algorithms. IEEE Transactions on Evolutionary Computation, v. 4, n.2, p. 164-171, 2000.

27. Relatório de Análise de Segurança do reator de pesquisas do IPEN IEA-R1 (RAS). Instituto de Pesquisas Energéticas e Nucleares.

28. ROSSI, R. H. P. S. Utilização de Redes Neurais na Monitoração da Potência do reator IEA-R1. Dissertação (Mestrado), Universidade de São Paulo - IPEN, 2001.

29. ROVITHAKIS, G. A.; MANIADAKIS, M.; ZERVAKIS, M. A Hybrid Neural Network/Genetic Algorithm to optimizing feature extraction for signal validation. IEEE Transactions on System, Man and Cybernetics - Part B: Cybernetics, v. 34, n. 1, 2001.

30. RUMMELharT, D. E.; MCCLELland, J. L. Parallel Distributed Processing: Explorations in the Microstructure of Cognition. MIT Press, 1986.

31. RUSINOV, L. A. et al. Fault diagnosis in chemical processes with application of hierarchical neural networks. Chemometrics and Intelligent Laboratory Systems, v. 97,n. 1, p. 98-103, 2009.

32. SAMANTA, B. Artificial Neural Networks and Genetic Algorithms for gear fault detection. Mechanical Systems and Signal Processing, v. 18, n. 3, p. 12731282, 2004.

33. SAMANTA, B. Gear fault detection using Artificial Neural Networks and support vector machines with genetic algorithms. Mechanical Systems and Signal Processing, v. 18, n. 3, p. 625-644, 2004.

34. SELIGER, B. K.; FRANK, P. M. Fault Detection and Isolation in Technical Processes with Neural Networks. Proceedings of the 34th Conference on Decision \& Control, New Orleans, v. 3, p. 2414-2419, 1995.

35. SIMANI, S.; FANTUZZI, C. Fault diagnosis in power plant using neural networks. Information Sciences, v. 127, n. 3-4, p. 125-136, 2000. 
36. SORSA, T.; KOIVO, H. Application of Artificial Neural Networks in Process Fault Diagnosis. Automatica, v. 29, p. 843-849, 1993.

37. UHRIG, R. E. Fault Monitoring using Neural Networks. Power Electronics and Motion Control in Industrial Electronics Control, Instrumentation and Automation, v. 3, p. 1449-1454, 1991.

38. UHRIG, R. E.; GUO, Z. Using genetic algorithms to select inputs for neural networks. Combinations of Genetic Algorithms and Neural Networks, v. 5, p. 223234, 1992.

39. UPADHYAYA, B. R.; ZHAO, K.; LU, B. Fault Monitoring of Nuclear Power Plant sensor and field devices. Progress in Nuclear Energy, v. 43, n. 1-4, p. 337342, 2003.

40. ZUPAN, J.; NOVIC, M.; RUISANCHEZ, I. Kohonen and counterpropagation artificial neural networks in analytical chemistry. Chemometrics and Intelligent Laboratory Systems, v. 38, n. 1, p. 1-23, 1997. 